\author{
Monograph \\ urn:1sid:zoobank.org:pub:8B61E9CD-DDCA-43FC-AB0A-B227C1A579E8
}

\title{
The Mollusca of Galicia Bank (NE Atlantic Ocean)
}

\author{
Serge GOFAS ${ }^{\circledR 1, *}$, Ángel A. LUQUE ${ }^{\circledR 2}$, Joan Daniel OLIVER ${ }^{3}$, \\ José TEMPLADO ${ }^{\circledR 4}$ \& Alberto SERRANO ${ }^{\circledR} 5$ \\ ${ }^{1}$ Departamento de Biología Animal, Facultad de Ciencias, Universidad de Málaga, \\ 29071 Málaga, Spain. \\ ${ }^{2}$ Centro de Investigación en Biodiversidad y Cambio Global (CIBC-UAM), \\ Universidad Autónoma de Madrid, c/ Darwin 2, 28049 Madrid, Spain. \\ ${ }^{3} \mathrm{C} /$ Alcorisa 83 12C, 28043 Madrid, Spain. \\ ${ }^{4}$ Museo Nacional de Ciencias Naturales (CSIC), c/ José Gutiérrez Abascal 2, 28006 Madrid, Spain. \\ ${ }^{5}$ Centro Oceanográfico de Santander, Instituto Español de Oceanografía, Apdo. 240 \\ Promontorio San Martín, s/n, 39080 Santander, Spain. \\ *Corresponding author: sgofas@uma.es \\ ${ }^{2}$ Email: angel.luque@inv.uam.es \\ ${ }^{3}$ Email: joandanieloliver@hotmail.com \\ ${ }^{4}$ Email: templado@mncn.csic.es \\ ${ }^{5}$ Email: alberto.serrano@ieo.es \\ ${ }^{1}$ urn:lsid:zoobank.org:author:C7A4B3D3-AE51-4376-BA89-249CD1F1632D
${ }^{2}$ urn:lsid:zoobank.org:author:829C1CA8-1530-46FF-A7C9-55682E44E7B3
${ }^{3}$ urn:1sid:zoobank.org:author:81A90DF7-933D-4B34-BE46-3630D93D57B9
${ }^{4}$ urn:1sid:zoobank.org:author:191D7CF3-7F05-47F1-AFE5-60567B3A448A
${ }^{5}$ urn:lsid:zoobank.org:author:8FCDBDC3-3609-46B6-9847-B2E7871E4BEC
}

\begin{abstract}
An illustrated checklist of the Mollusca of Galicia Bank, a large and deep seamount off the NW Iberian Peninsula, is provided. The studied material was collected in 8 samples of SEAMOUNT 1 cruise (1987), 7 samples of ECOMARG 0709 (2009) and 36 samples of BANGAL 0711 (2011), between 615 and $1768 \mathrm{~m}$. A total of 212 species are known to occur at the Galicia Bank (1 Monoplacophora, 7 Solenogastres, 3 Polyplacophora, 132 Gastropoda, 54 Bivalvia, 6 Scaphopoda, and 9 Cephalopoda), 21 of which from previous studies only. Four species are described as new, 34 species are first record in Spanish waters and another 20 species first record for the Northern Spanish waters. Over 7500 specimens, representing 104 species, were collected alive, and 87 species were represented by empty shells only. Only 53 species were detected in both SEAMOUNT 1 and BANGAL 0711; most of the species are rare and more species can be expected if exploration is continued. There is a marked difference in species composition between the summit platform (615-1000 m) and the deeper part below $1500 \mathrm{~m}$, with some genera (e.g., Colus and Limopsis) represented by alternative species. Endemism, if any, is very low and most of the species are widespread.
\end{abstract}

Keywords. Seamount, marine protected area, benthos, taxonomy, species richness. 
Gofas S., Luque Á.A., Oliver J.D., Templado J. \& Serrano A. 2021. The Mollusca of Galicia Bank (NE Atlantic Ocean). European Journal of Taxonomy 785: 1-114. https://doi.org/10.5852/ejt.2021.785.1605

\section{Introduction}

Seamounts, such as Galicia Bank, are habitats of special interest due to their peculiar hydrological and sedimentary dynamics, and the fact that they harbour extensive hard substrate outcrops in deep-sea areas where soft substrates are usually prevalent (Wilson \& Kaufmann 1987; Rogers 1994, 2018; Wessel 2007). Seamounts are defined as undersea topographic elements that rise more than 1000 meters above the surrounding seafloor, but currently there is a trend to use this term for reliefs of lesser elevation (Staudigel et al. 2010; Vázquez et al. 2015; Rogers 2018). From a biogeographical point of view they are as isolated as the emerged islands, taking into account that the organisms living on seamounts generally cannot live in the surrounding bathyal or abyssal bottoms and have reached the seamounts through dispersal events. A review on the structure, function and ecology of seamounts can be seen in Clark et al. (2010).

There are ca 810 seamounts in the North Atlantic Ocean, most of them along the Mid-Atlantic Ridge (Rogers 1994, 2018; Gubbay 2003). According to the official OSPAR database, 104 seamounts are within its area of competence, 74 of them located within the national Economic Exclusive Zone (EEZ) and only 30 in the High Seas (OSPAR Commission 2010). A total of 46 main seamounts are located along the Iberian margins (Vázquez et al. 2015).

The Galicia Bank (hereafter GB), is a large Northeast Atlantic seamount located about 120 nautical miles off NW Spanish coast and separated from the Iberian continental margin by the Galicia Inner Basin of ca $2500 \mathrm{~m}$ depth (Fig. 1). It is therefore qualified as a "coastal" seamount in contrast to oceanic seamounts such as the South Azorean Seamount Chain (Surugiu et al. 2008). With its summit at $625 \mathrm{~m}$ of depth, it can be classified as a deep seamount (White \& Mohn 2004).

Because of its difficult access and of its depth, information about the GB has long remained scanty. It was probably known by Galician fishermen for decades, but the available scientific information is recent. The sinking of the 'Prestige' oil tanker in 2002 SW of the GB focused interest in this area and promoted intensive and multidisciplinary studies (e.g., Albaigés et al. 2006; Alonso et al. 2008; Ercilla \& Vilas 2008; Vázquez et al. 2008, 2015; Ercilla et al. 2011), but knowledge about the biological and ecological aspects of the area is still limited.

The GB had remained off the track of the great explorations of the nineteenth century, which still provide a significant part of our knowledge of deep benthos. Surprisingly, it was discovered only in the mid-twentieth century (Heezen 1959; Black et al. 1964) and the first data on its fauna were provided by fisheries surveys carried out with fishing vessels by the Instituto de Investigaciones Marinas of Vigo (IIMV) during 1980-1981 (Rolán Mosquera \& Pérez-Gándaras 1981). These preliminary data encouraged that the French SEAMOUNT 1 survey (September/October 1987), essentially directed to other seamounts further to the South (Gorringe, Josephine, Ampère, Lion, Seine), also visited GB (Bouchet \& Métivier 1988). Furthermore, during the "FAUNA II" cruise (July 1991) two samples were taken in the upper zone of the GB and some results were published by García-Alvarez et al. (2000, 2001), Garcia-Alvarez \& Salvini-Plawen (2001), García-Alvarez \& Urgorri (2001), Salvini-Plawen (2006), on Solenogastres Gegenbaur, 1878, and Rolán \& Suárez (2007) on Calliostoma Swainson, 1840.

Within the framework of the OMEX-II (Ocean Margin Exchange) programme (see Lavaleye et al. 2002), some data on the meio- and macrofauna community structure in relation to sediment composition 
of GB were provided by Flach et al. (2002), while Duineveld et al. (2004) revealed high concentrations of nutrients in the environment and the presence of deep-water corals in the bank's summit platform.

The German R/V Victor Hensen visited GB in April-May 1997 during the VH97 cruise, and collected five grab samples on the upper part of the bank between 760 and $880 \mathrm{~m}$. That material was not available to use but provided one species of gastropod described by Engl et al. (2021).

In 2009, the Spanish Institute of Oceanography (IEO) carried out the ECOMARG program in several sites of the Iberian margin, including the GB. Also in 2009, the Diva-Artabria II-09 survey within the

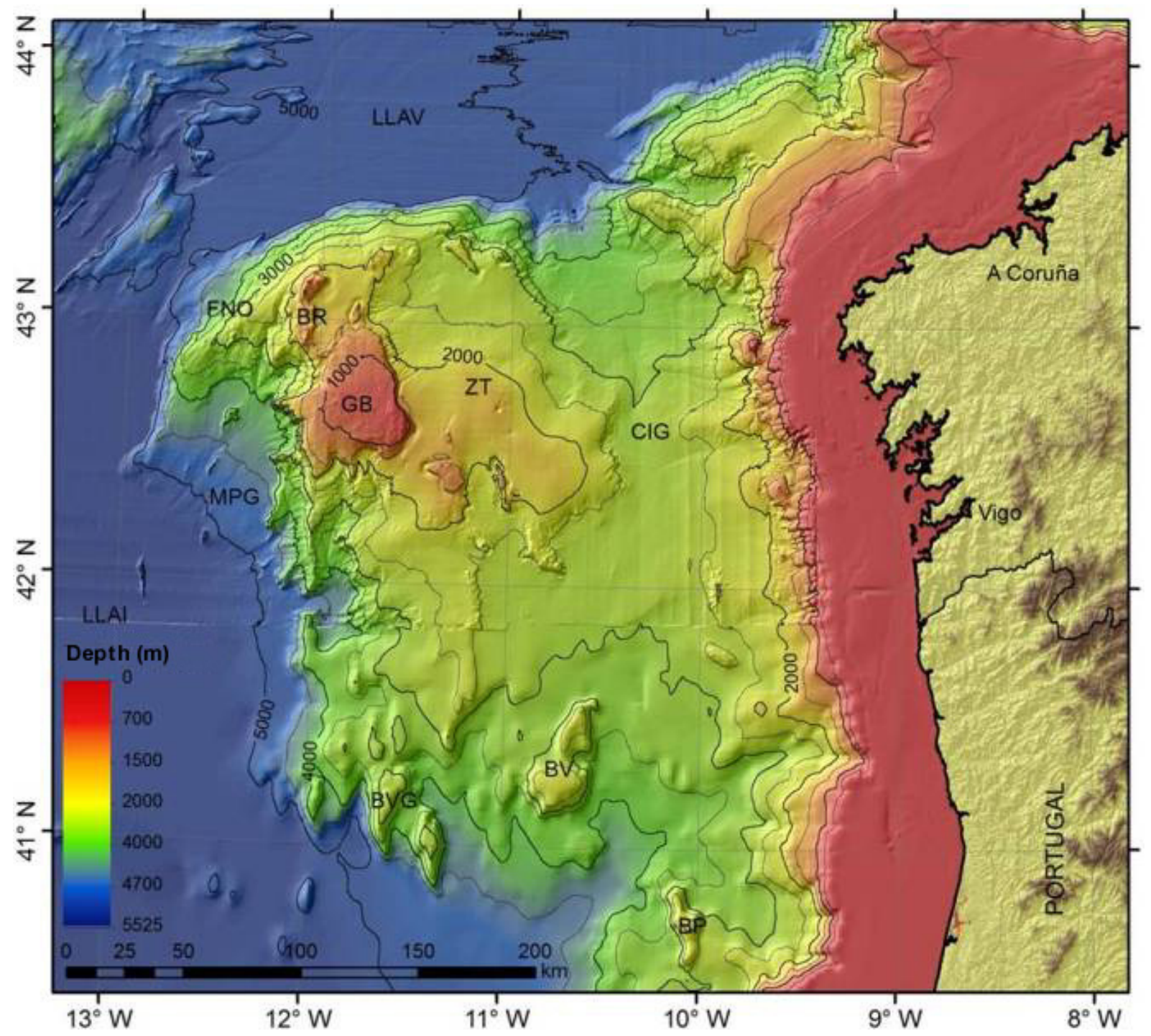

Fig. 1. The NW Iberian continental margin, with situation of the Galicia Bank (hereafter GB) and other geomorphological features of the area: Vasco da Gama Seamounts (BVG), Vigo Bank (BV), Oporto Bank (BP), Galicia Inner Basin (CIG), transition zone (ZT), northwestern flank (FNO), Rucabado and García seamounts (BR), the deep margin of Galicia (MPG), the Bay of Biscay abyssal plain (LLAV) and the Iberian abyssal plain (LLAI). Source: EEZ Project (multibeam echo sounder bathymetry) and GEBCO Digital Atlas. 
project "Latitudinal gradients of biodiversity in the deep sea of the Atlantic Ocean" sampled Galicia Bank (Somoza et al. 2014), but this material was not available to us.

In recent years, an important effort has been allocated to the study of ten areas of Spanish jurisdictional waters within the LIFE+INDEMARES project "Inventory and designation of marine Natura 2000 areas in the Spanish Sea", whose main objective is to complete the identification of the high seas areas to be included in the Natura 2000 Network of Spain. This project intended to meet the commitments of the Framework Directive of the EU Marine Strategy and Aichi Biodiversity Target 11 of the Convention of Biological Diversity (CBD), which requires "10 per cent of coastal and marine areas, especially areas of particular importance for biodiversity and ecosystem services, are conserved through effectively and equitably managed, ecologically representative and well connected systems of protected areas". The Galicia Bank was one of the ten areas prospected and was the objective of the INDEMARES BANGAL 0711 survey (from July 18 to August 10, 2011) with the R/V “Miguel Oliver" (see de la Torriente et al. 2014 for a general overview). As a follow-up of this programme, GB was formally proposed as a candidate Site of Community Importance (SCI) in July 2014 (Ministerio de Agricultura, Alimentación y Medio Ambiente 2014) and was adopted in the ninth update of the list of Sites of Community Importance for the Atlantic biogeographical region in November 2015. Furthermore, GB is one of the areas under evaluation for habitat monitoring in the European Union's Marine Strategy Framework Directive (2008/56/CE).

Among other reasons, this area was considered relevant for further research and conservation actions because of the presence of well developed and conserved priority habitats catalogued as vulnerable (OSPAR Commission 2008; Council of the European Communities 1992), such as cold-water coral community (reefs of Lophelia pertusa (Linnaeus, 1758) [currently Desmophyllum pertusum] and Madrepora oculata Linnaeus, 1758), and black and bamboo coral aggregations (Duineveld et al. 2004; Somoza et al. 2014; de la Torriente et al. 2014). Besides, the presence of some vulnerable species such as deep-water sharks (Bañón et al. 2016) and carnivorous sponges (Cristobo et al. 2015) has also been recorded. The presence of vulnerable habitats and threatened species listed on international conventions or lists, such as the Convention for the Protection of the Marine Environment of the Northeast Atlantic (OSPAR) or the International Union for Conservation of Nature (IUCN), is one of the key factors in conservation actions in both Habitats and Marine Strategy EU directives.

Several studies of some animal groups in the GB have been published as a result of the SEAMOUNT 1 or INDEMARES BANGAL 0711 surveys, such as polychaetes (Surugiu et al. 2008), decapod crustaceans (Cartes et al. 2014), fish (Bañón et al. 2016) and bryozoans (Souto et al. 2016), and some new species have been described (Baba \& Macpherson 2012; Vicente et al. 2014; Gofas et al. 2014a; Cristobo et al. 2015; Souto et al. 2016). More recently, a couple of papers on the benthic habitats and communities of GB have been published by Serrano et al. (2017a, 2017b).

Molluscs are a conspicuous and important component of the seamount macrobenthos and the marine benthos in general. Several studies on some NE Atlantic seamounts have revealed the molluscan biodiversity richness (Peñas \& Rolán 1999; Gofas 2000, 2002, 2005, 2007; Gofas \& Beu 2002; Ávila \& Malaquias 2003; Dijkstra \& Gofas 2004; Krylova 2006; Hoffman et al. 2010, 2011a, 2011b, 2020a, 2020b, 2020c; Hoffman \& Freiwald 2017; Peñas et al. 2019; Gofas \& Hoffman 2020). Though molluscs also are a main component of GB benthos, only scattered references on the GB molluscan fauna were included in the context of broader taxonomic works (Rolán Mosquera \& Pérez-Gándaras 1981; Rolán Mosquera 1983; Bouchet \& Warén 1993; Dijkstra \& Gofas 2004; Gofas 2007; Hoffman et al. 2019a; Engl et al. 2021) or in papers focused on particular species (Warén \& Bouchet 1990; SalviniPlawen 2006; Gofas et al. 2014a). Moreover, some mollusc species collected during SEAMOUNT 1 and INDEMARES BANGAL 0711 surveys were recorded by Serrano et al. (2017a, 2017b) and de la 
Torriente et al. (2014), but despite of the fairly abundant material obtained from the above mentioned surveys, an exhaustive list of GB molluscs has not been published yet.

The objective of this paper is to increase the knowledge of the molluscan biodiversity of the GB synthesizing the information at hand, based essentially on samples collected by INDEMARES BANGAL 0711 and SEAMOUNT 1 surveys, but also on some other cruises and the published data from other sources.

\section{Material and methods}

\section{Study area}

The Galicia Bank is located entirely within the bathyal level, with an extensive summit platform culminating at $625 \mathrm{~m}$ depth. It is irregularly shaped, with a length of ca $60 \mathrm{~km}$ in the direction of its $\mathrm{E}-\mathrm{W}$ axis and $84 \mathrm{~km}$ in the direction of the $\mathrm{N}-\mathrm{S}$ axis, with the northern and western parts gently sloping towards the abyssal plain and the eastern edge forming a cliff to ca $1800 \mathrm{~m}$. The bank is surrounded to the west and southwest by the Iberian Abyssal Plain, to the north by the Bay of Biscay Abyssal Plain, both deeper than $5000 \mathrm{~m}$, and to the east by the Interior Basin of Galicia, with somewhat shallower depths of about $2500 \mathrm{~m}$ (Fig. 1). To the N-NW Rucabado and García Seamounts are located connecting with the Galicia escarpment, named the Northwestern Flank by Vázquez et al. $(2008,2015)$. The area delimited by the $1600 \mathrm{~m}$ isobath covers $2368 \mathrm{~km}^{2}$.

Regarding water masses in contact with the sea bottom (Fiúza et al. 1998), the bank receives from the south some quite diluted waters of deep Mediterranean origin (Mediterranean Outflow Water, MOW) in two intervals of depth, the upper core centered around $780 \mathrm{~m}$ and the lower and more saline core around 1100-1200 m. A wedge of less saline and colder water from the Labrador (Labrador Sea Water, LSW), which lies between 1500 and $1800 \mathrm{~m}$ and moves southwards, locally accentuates the gradient with the deepest Mediterranean outflow. In the still deeper part, North Atlantic Water (NADW) has a core located around 2500-3000 m (de la Torriente et al. 2014). At the top of the bank, temperature was $11.15-11.17^{\circ} \mathrm{C}$, at the bank break around $10.8^{\circ} \mathrm{C}$, and in the deepest part (about $1600 \mathrm{~m}$ ) drops to $6.07^{\circ} \mathrm{C}$ (Serrano et al. 2017a).

The substrate of the GB consists of basaltic lavas and oceanic crust, covered by sediments which are largely of pelagic origin (Ercilla et al. 2011). The Galicia Bank forms, along with the smaller banks of Vasco da Gama, Vigo and Oporto, a barrier relatively parallel to the coast. Towards the coast, the Interior Basin of Galicia captures the majority of the sediments originating from the continent (most of them are fluvial contributions of the Miño and Duero river basins) and channels them to the north and the south, preventing their arrival to Galicia Bank. Thus, the only sources of sediment on the bank itself, apart from the erosion of the substrate, are the remains of carbonate skeletons of the organisms that live on it, and the shells of small planktonic organisms which, after their death, sink to the bottom.

The platform located at the top of the bank is subject to strong currents (up to $30 \mathrm{~cm} \mathrm{~s}^{-1}$ ). As a consequence of the obstacle which the current encounters against the seamount, stable eddies known as Taylor columns are formed, favouring a strong vertical mixing, a great primary production in superficial waters, and the retention of this production in the area. This facilitates the presence of aggregations of fish, especially large pelagic species, as well as of cetaceans and seabirds. These conditions also favour the development of large benthic species, especially filter-feeders such as corals and sponges which in turn contribute to increase structural complexity (de la Torriente et al. 2014).

The main benthic habitats and communities of the GB were described by Serrano et al. (2017a, 2017b). A large part of the summit (the shallowest part) is covered by a field of bioclastic sand waves with a medium grain size and low organic matter covering a total area of $215 \mathrm{~km}^{2}$ (Duineveld et al. 2004; 
Somoza et al. 2014). This sedimentary bottom is mainly dominated by ophiuroids (Serrano et al. 2017a). Somewhat deeper in the summit (at a depth of 800-1000 m) some semi-buried and exposed mounds of dead cold-water corals and coral debris appear with isolated patches of living reef of Desmophyllum pertusum (formerly known as Lophelia pertusa) and Madrepora oculata (Somoza et al. 2014). A seabed with polymetallic nodules was located south of the top of the bank at 800-900 m (de la Torriente et al. 2014). The bank break at the border of the summit, in the range 1000-1200 m, is characterized by rocky outcrops and an assemblage dominated by the urchin Cidaris cidaris Linnaeus, 1758 and the sponge Thenea muricata (Bowerbank, 1858). The flanks around the bank are partially covered by fine sands with the highest contents of organic matter. On the barren basalt hardgrounds black and bamboo corals, gorgonians and sponges form different assemblages. The deepest assemblage (1400-1800 m) is dominated by the holothurian Benthogone rosea Koehler, 1895. True and well-developed reefs of living cold-water corals (CWC hereafter) were located in Rucabado seamount in the depth range 1100-1200 m (Serrano et al. 2017b).

\section{Material studied and sampling}

The major part of the material studied was collected during the INDEMARES BANGAL 0711 survey. Additional material from previous cruises (fishing surveys of IIMV, 1980-1981; SEAMOUNT 1, 1987; ECOMARG 0709, 2009) was also studied, and previously published records (most of them based on SEAMOUNT 1 and FAUNA II samples) have been added to the species list.

In the INDEMARES BANGAL 0711 survey (chief scientist Alberto Serrano, Instituto Español de Oceanografía), operations were carried out with a rock dredge (15 hauls, between 779 and $1697 \mathrm{~m}$ deep), a beam trawl (11 hauls, between 744 and $1720 \mathrm{~m}$ deep), and an otter trawl (9 hauls, between 751 and $1764 \mathrm{~m}$ depth). A suprabenthic sled, pelagic nets, underwater video recording and CTD measurements were also performed. The processing of the biological samples was similar to the previous SEAMOUNT 1 and FAUNA II cruises. The coarse fractions, usually above $10 \mathrm{~mm}$, were mostly sorted on board to major taxonomic groups and then separated to the species level in the laboratory. The finest fractions were preserved on board as bulk samples, and later sieved through 5, 2, 1 and $0.5 \mathrm{~mm}$ meshes, for separation under a stereoscopic microscope. Live animals were drawn and photographed on board whenever possible. Most of the material obtained consisted of shells, which have been taken into account in the recording of molluscs. The molluscan specimens of the INDEMARES surveys are currently at the laboratories of Universidad Autónoma de Madrid and Universidad de Málaga, and are to be deposited after their study in the Museo Nacional de Ciencias Naturales, Madrid (MNCN).

The "SEAMOUNT 1" cruise took place in September and October 1987 (chief scientist Philippe Bouchet, Museum national d'Histoire naturelle, Paris, hereafter MNHN), on board R/V "Le Noroit". Operations were carried out using a rock dredge (station numbers beginning with DW, see Table 1) or with a beam trawl (CP), and samples were processed as described in the preceding paragraph. The material of the "SEAMOUNT 1" cruise is shared between the Swedish Museum of Natural History of Stockholm (SMNH), and MNHN.

The ECOMARG 0709 cruise (chief scientist Francisco Sánchez, Instituto Español de Oceanografía) visited Le Danois Bank (also known as 'El Cachucho'), Cañón de Avilés and Galicia Bank, on board $\mathrm{R} / \mathrm{V}$ "Cornide de Saavedra" in July 2009. On Galicia Bank, benthic operations included one rock dredge, 5 beam trawl and 3 otter trawl operations, all of them restricted to the summit platform of the bank (between 615 and $833 \mathrm{~m}$ depth). A preliminary report on the molluscs was presented by Salas et al. (2011).

Table 1 shows data, geographical coordinates and depth of the stations sampled and Fig. 2 shows their situation in the GB. 
All live-taken specimens from INDEMARES BANGAL 0711 were quantified and used for an analysis of the affinity between samples. Most of these were stored in $70^{\circ}$ ethanol and are available to the scientific community for further studies, including DNA sequencing. The SEAMOUNT 1 material has been sorted at the species level, mostly at Swedish Museum of Natural History, Stockholm, under the supervision of Anders Warén, but the abundance of each species and the proportion of live collected specimens have not been systematically quantified. Most of the molluscan material from all surveys consisted of shells and was stored dry. The empty shells in good condition have been considered, since they represent the potentially living fauna in bathyal areas where the population density of living individuals is low.

Illustrations are herein provided (Figs 3-44) for most of the species and emphasis is placed on those which are characteristic of certain habitats, in order to provide a tool that facilitates future monitoring of

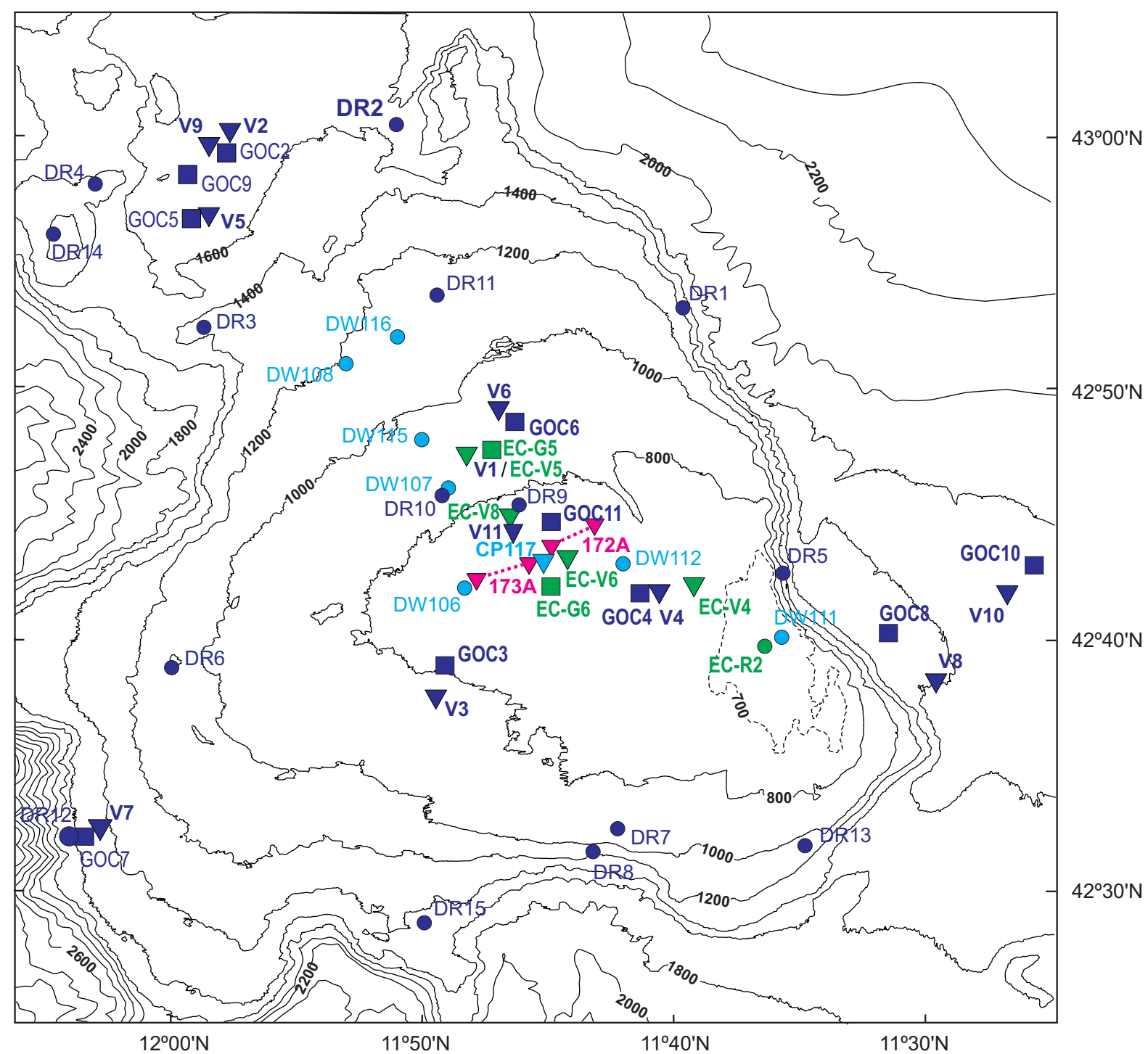

Fig. 2. Location of benthic samples used in this paper: SEAMOUNT 1 (turquoise), FAUNA II (red), ECOMARG 0709 (green) and INDEMARES BANGAL 0711 (deep blue). Symbols for sampling gears: rock dredge (circles; DW, R or DR), beam trawl (triangles; A, V or CP), otter trawl (squares; G or GOC). Isobaths every $200 \mathrm{~m}$ except for shallowest at $700 \mathrm{~m}$; isobaths on the bank proper down to $2000 \mathrm{~m}$ from multibeam bathymetry (EEZ Project), completed with GEBCO regional bathymetry for the surroundings. 
Table 1 (continued on next page). Sampling stations with their corresponding data, geographical coordinates and depth $(\mathrm{m})$. Codes for sampling gears: DW, R, DR = rock dredge; A, CP, V = beam trawl; G, GOC = otter trawl.

\begin{tabular}{|c|c|c|c|c|c|c|}
\hline Cruise & Station & Latitude & Longitude & Depth (m) & Date & $\begin{array}{c}\text { Abbreviation in } \\
\text { Table } 2\end{array}$ \\
\hline \multirow{8}{*}{ SEAMOUNT 1} & DW106 & $42^{\circ} 42^{\prime} \mathrm{N}$ & $11^{\circ} 48^{\prime} \mathrm{W}$ & 765 & 18 Oct. 1987 & DW106 \\
\hline & DW107 & $42^{\circ} 46^{\prime} \mathrm{N}$ & $11^{\circ} 49^{\prime} \mathrm{W}$ & $850-870$ & 18 Oct. 1987 & DW107 \\
\hline & DW108 & $42^{\circ} 51^{\prime} \mathrm{N}$ & $11^{\circ} 53^{\prime} \mathrm{W}$ & $1110-1125$ & 19 Oct. 1987 & DW108 \\
\hline & DW111 & $42^{\circ} 40^{\prime} \mathrm{N}$ & $11^{\circ} 36^{\prime} \mathrm{W}$ & $675-685$ & 19 Oct. 1987 & DW111 \\
\hline & DW112 & $42^{\circ} 43^{\prime} \mathrm{N}$ & $11^{\circ} 42^{\prime} \mathrm{W}$ & $760-770$ & 19 Oct. 1987 & DW112 \\
\hline & DW115 & $42^{\circ} 48^{\prime} \mathrm{N}$ & $11^{\circ} 50^{\prime} \mathrm{W}$ & $880-885$ & 19 Oct. 1987 & DW115 \\
\hline & DW116 & $42^{\circ} 52^{\prime} \mathrm{N}$ & $11^{\circ} 51^{\prime} \mathrm{W}$ & $985-1000$ & 20 Oct. 1987 & DW116 \\
\hline & CP117 & $42^{\circ} 43^{\prime} \mathrm{N}$ & $11^{\circ} 45^{\prime} \mathrm{W}$ & 770 & 20 Oct. 1987 & CP117 \\
\hline \multirow{2}{*}{ FAUNA II } & $172 \mathrm{~A}$ & $\begin{array}{c}42^{\circ} 43.65^{\prime}- \\
42^{\circ} 44.70^{\prime} \mathrm{N}\end{array}$ & $\begin{array}{c}11^{\circ} 44,99^{\prime}- \\
11^{\circ} 43.36^{\prime} \mathrm{W}\end{array}$ & $761-768$ & 28 Jun. 1991 & FI-II 172A \\
\hline & $173 \mathrm{~A}$ & $\begin{array}{l}42^{\circ} 42.37^{\prime}- \\
42^{\circ} 43.00^{\prime} \mathrm{N}\end{array}$ & $\begin{array}{c}11^{\circ} 47.87^{\prime}- \\
11^{\circ} 45.78^{\prime} \mathrm{W}\end{array}$ & $760-769$ & 28 Jun. 1991 & FI-II 173A \\
\hline \multirow{7}{*}{$\begin{array}{c}\text { ECOMARG } \\
0709\end{array}$} & $\mathrm{R} 2$ & $42^{\circ} 39.95^{\prime} \mathrm{N}$ & $11^{\circ} 36.42^{\prime} \mathrm{W}$ & 615 & 23 Jul. 2009 & ECR2 \\
\hline & V4 & $42^{\circ} 42.42^{\prime} \mathrm{N}$ & $11^{\circ} 39.31^{\prime} \mathrm{W}$ & 735 & 22 Jul. 2009 & ECV4 \\
\hline & V5 & $42^{\circ} 47.40^{\prime} \mathrm{N}$ & $11^{\circ} 48.26^{\prime} \mathrm{W}$ & 876 & 23 Jul. 2009 & ECV5 \\
\hline & V6 & $42^{\circ} 43.26^{\prime} \mathrm{N}$ & $11^{\circ} 44.23^{\prime} \mathrm{W}$ & 766 & 23 Jul. 2009 & ECV6 \\
\hline & V8 & $42^{\circ} 45.01^{\prime} \mathrm{N}$ & $11^{\circ} 46.58^{\prime} \mathrm{W}$ & 782 & 25 Jul. 2009 & ECV8 \\
\hline & G5 & $42^{\circ} 47.33^{\prime} \mathrm{N}$ & $11^{\circ} 47.45^{\prime} \mathrm{W}$ & 863 & 23 Jul. 2009 & ECG5 \\
\hline & G6 & $42^{\circ} 42.17^{\prime} \mathrm{N}$ & $11^{\circ} 44.88^{\prime} \mathrm{W}$ & 764 & 23 Jul. 2009 & ECG6 \\
\hline \multirow{22}{*}{ BANGAL 0711} & DR1 & $42^{\circ} 53.21^{\prime} \mathrm{N}$ & $11^{\circ} 39.69^{\prime} \mathrm{W}$ & 1414 & 20 Jul. 2011 & DR1 \\
\hline & DR2 & $43^{\circ} 00.36^{\prime} \mathrm{N}$ & $11^{\circ} 51.00^{\prime} \mathrm{W}$ & 1697 & 20 Jul. 2011 & DR2 \\
\hline & DR3 & $42^{\circ} 52.48^{\prime} \mathrm{N}$ & $11^{\circ} 58.62^{\prime} \mathrm{W}$ & 1313 & 21 Jul. 2011 & DR3 \\
\hline & DR4 & $42^{\circ} 58.42^{\prime} \mathrm{N}$ & $12^{\circ} 02.98^{\prime} \mathrm{W}$ & 1288 & 22 Jul. 2011 & DR4 \\
\hline & DR5 & $42^{\circ} 42.63^{\prime} \mathrm{N}$ & $11^{\circ} 35.63^{\prime} \mathrm{W}$ & 1099 & 23 Jul. 2011 & DR5 \\
\hline & DR6 & $42^{\circ} 38.87^{\prime} \mathrm{N}$ & $11^{\circ} 59.92^{\prime} \mathrm{W}$ & 1035 & 24 Jul. 2011 & DR6 \\
\hline & DR7 & $42^{\circ} 32.39^{\prime} \mathrm{N}$ & $11^{\circ} 42.35^{\prime} \mathrm{W}$ & 938 & 25 Jul. 2011 & DR7 \\
\hline & DR8 & $42^{\circ} 31.60^{\prime} \mathrm{N}$ & $11^{\circ} 43.26^{\prime} \mathrm{W}$ & 1138 & 25 Jul. 2011 & DR8 \\
\hline & DR9 & $42^{\circ} 45.31^{\prime} \mathrm{N}$ & $11^{\circ} 46.27^{\prime} \mathrm{W}$ & 779 & 26 Jul. 2011 & DR9 \\
\hline & DR10 & $42^{\circ} 45.90^{\prime} \mathrm{N}$ & $11^{\circ} 49.12^{\prime} \mathrm{W}$ & 826 & 26 Jul. 2011 & DR10 \\
\hline & DR11 & $42^{\circ} 53.63^{\prime} \mathrm{N}$ & $11^{\circ} 49.41^{\prime} \mathrm{W}$ & 1100 & 4 Aug. 2011 & DR11 \\
\hline & DR12 & $42^{\circ} 32.16^{\prime} \mathrm{N}$ & $12^{\circ} 03.79^{\prime} \mathrm{W}$ & 1585 & 5 Aug. 2011 & DR12 \\
\hline & DR13 & $42^{\circ} 31.88^{\prime} \mathrm{N}$ & $11^{\circ} 34.73^{\prime} \mathrm{W}$ & 1046 & 6 Aug. 2011 & DR13 \\
\hline & DR14 & $42^{\circ} 56.01^{\prime} \mathrm{N}$ & $12^{\circ} 05.02^{\prime} \mathrm{W}$ & 1130 & 7 Aug. 2011 & DR14 \\
\hline & DR15 & $42^{\circ} 28.81^{\prime} \mathrm{N}$ & $11^{\circ} 50.03^{\prime} \mathrm{W}$ & 1410 & 8 Aug. 2011 & DR15 \\
\hline & V1 & $42^{\circ} 47.34^{\prime} \mathrm{N}$ & $11^{\circ} 48.18^{\prime} \mathrm{W}$ & 867 & 26 Jul. 2011 & $\mathrm{~V} 1$ \\
\hline & $\mathrm{V} 2$ & $43^{\circ} 00.12^{\prime} \mathrm{N}$ & $11^{\circ} 57.67^{\prime} \mathrm{W}$ & 1706 & 29 Jul. 2011 & $\mathrm{~V} 2$ \\
\hline & V3 & $42^{\circ} 37.77^{\prime} \mathrm{N}$ & $11^{\circ} 49.46^{\prime} \mathrm{W}$ & 818 & 30 Jul. 2011 & V3 \\
\hline & V4 & $42^{\circ} 41.94^{\prime} \mathrm{N}$ & $11^{\circ} 40.58^{\prime} \mathrm{W}$ & 744 & 31 Jul. 2011 & V4 \\
\hline & V5 & $42^{\circ} 56.77^{\prime} \mathrm{N}$ & $11^{\circ} 58.53^{\prime} \mathrm{W}$ & 1631 & 2 Aug. 2011 & V5 \\
\hline & V6 & $42^{\circ} 49.19^{\prime} \mathrm{N}$ & $11^{\circ} 46.89^{\prime} \mathrm{W}$ & 909 & 3 Aug. 2011 & V6 \\
\hline & V7 & $42^{\circ} 32.50^{\prime} \mathrm{N}$ & $12^{\circ} 02.78^{\prime} \mathrm{W}$ & 1462 & 5 Aug. 2011 & V7 \\
\hline
\end{tabular}


Table 1 (continued). Sampling stations with their corresponding data, geographical coordinates and depth (m). Codes for sampling gears: DW, R, DR = rock dredge; A, CP, V = beam trawl; G, GOC = otter trawl.

\begin{tabular}{|c|c|c|c|c|c|c|}
\hline Cruise & Station & Latitude & Longitude & Depth (m) & Date & $\begin{array}{c}\text { Abbreviation in } \\
\text { Table } 2 \\
\end{array}$ \\
\hline \multirow{14}{*}{ BANGAL 0711} & V8 & $42^{\circ} 38.48^{\prime} \mathrm{N}$ & $11^{\circ} 29.68^{\prime} \mathrm{W}$ & 1565 & 6 Aug. 2011 & V8 \\
\hline & V9 & $42^{\circ} 59.61^{\prime} \mathrm{N}$ & $11^{\circ} 58.41^{\prime} \mathrm{W}$ & 1671 & 7 Aug. 2011 & V9 \\
\hline & V10 & $42^{\circ} 41.87^{\prime} \mathrm{N}$ & $11^{\circ} 26.71^{\prime} \mathrm{W}$ & 1720 & 8 Aug. 2011 & V10 \\
\hline & V11 & $42^{\circ} 44.21^{\prime} \mathrm{N}$ & $11^{\circ} 46.35^{\prime} \mathrm{W}$ & 768 & 9 Aug. 2011 & V11 \\
\hline & GOC2 & $42^{\circ} 59.36^{\prime} \mathrm{N}$ & $11^{\circ} 57.76^{\prime} \mathrm{W}$ & 1672 & 28 Jul. 2011 & GOC2 \\
\hline & GOC3 & $42^{\circ} 38.97^{\prime} \mathrm{N}$ & $11^{\circ} 49.09^{\prime} \mathrm{W}$ & 785 & 30 Jul. 2011 & GOC3 \\
\hline & GOC4 & $42^{\circ} 41.938^{\prime} \mathrm{N}$ & $11^{\circ} 41.19^{\prime} \mathrm{W}$ & 751 & 31 Jul. 2011 & GOC4 \\
\hline & GOC5 & $42^{\circ} 56.81^{\prime} \mathrm{N}$ & $11^{\circ} 59.08^{\prime} \mathrm{W}$ & 1656 & 2 Aug. 2011 & GOC5 \\
\hline & GOC6 & $42^{\circ} 49.13^{\prime} \mathrm{N}$ & $11^{\circ} 46.59^{\prime} \mathrm{W}$ & 903 & 4 Aug. 2011 & GOC6 \\
\hline & GOC7 & $42^{\circ} 32.24^{\prime} \mathrm{N}$ & $12^{\circ} 03.43^{\prime} \mathrm{W}$ & 1536 & 5 Aug. 2011 & GOC7 \\
\hline & GOC8 & $42^{\circ} 40.34^{\prime} \mathrm{N}$ & $11^{\circ} 31.62^{\prime} \mathrm{W}$ & 1485 & 6 Aug. 2011 & GOC8 \\
\hline & GOC9 & $42^{\circ} 58.50^{\prime} \mathrm{N}$ & $11^{\circ} 59.24^{\prime} \mathrm{W}$ & 1683 & 7 Aug. 2011 & GOC9 \\
\hline & GOC10 & $42^{\circ} 42.98^{\prime} \mathrm{N}$ & $11^{\circ} 25.61^{\prime} \mathrm{W}$ & 1764 & 8 Aug. 2011 & GOC10 \\
\hline & GOC11 & $42^{\circ} 44.69^{\prime} \mathrm{N}$ & $11^{\circ} 44.98^{\prime} \mathrm{W}$ & 765 & 9 Aug. 2011 & GOC11 \\
\hline
\end{tabular}

this marine protected area. Photographs were taken using a Nikon DXM camera mounted on a binocular stereo microscope, and then different views of the same specimen, focused on distinct planes, were assembled using the Combine ZP software (Hadley 2006). The images were stored in digital format, treated with the software Adobe Photoshop 5 to enhance contrast and clean the background. The detail of figure numbers for each species is given in Table 2. Different views of the same whole shell are always to scale, but not the different shells on the same plate. Shipboard drawings of living animals, made during the SEAMOUNT 1 cruise are presented in Supp. file 1 (Fig. S1)

Scanning electron micrographs were obtained mostly using a JEOL JCC 1100 scanning electron microscope at the Servicios Centrales de Apoyo a la Investigación of University of Málaga. For this, the shells were soaked in a $10 \%$ solution of sodium lauryl sulphate prior to a brief cleaning in an ultrasonic cleaner (except for very fragile shells which do not withstand this), then dried and mounted on stubs over an adhesive copper tape, and metallized. After imaging, the shells were unmounted and replaced in the collection with a reference to the image file. Some shells have been imaged with a variable-pressure scanning electron microscope (SEM) Hitachi S-3000N at the Inter-Departmental Research Service (SIDI) of Universidad Autónoma, Madrid, which operates with low vacuum and low voltage and backscatter detector, that allows to work with samples without metallizing.

The identification of the species was carried out using the reference taxonomic bibliography for the NE Atlantic regarding gastropods (Bouchet \& Warén 1980, 1985, 1986, 1993; Warén 1989a, 1991, 1992, 1993, 1996; Beck et al. 2006; Hoffman et al. 2010, 2011a, 2011b, 2019a, 2019b), bivalves (Sanders \& Allen 1973, 1977; Allen \& Turner 1974; Oliver \& Allen 1980a, 1980b; Allen \& Morgan 1981; Allen \& Hannah 1989; Warén 1989b; Allen et al. 1995; Salas 1996; Salas \& Gofas 1997; Dijkstra \& Gofas 2004; Killeen \& Turner 2009; Oliver 2012, 2013) and scaphopods (Steiner \& Kabat 2004), but also the classical works reporting on the XIX $^{\text {th }}$ century deep-sea expeditions (Jeffreys 1878-1885; Locard 1897-1898; Dautzenberg \& Fischer 1896, 1897). Nomenclature and classification were checked against the World Register of Marine Species (WoRMS editorial board 2021). Keys are provided for some species-rich and difficult groups, but it must 
be taken into account that additional collecting is likely to bring in species not considered here. The new species, and those species which raise taxonomic issues, are given species entries in the main text, with a list of material examined, and a description and/or remarks. Other species of our material are only illustrated, listed in Table 2 and the material examined listed in the Supp. file 2 (Table S1).

The similarity between samples of the INDEMARES BANGAL 0711 cruise was evaluated using both qualitative (presence/absence) and quantitative data (fourth root transformed abundance data) of livecollected specimens per sample; the transformation is meant to mitigate the influence of highly dominant taxa. The Bray-Curtis similarity index was used as a meaningful and robust measure (Clarke 1993) for obtaining a cluster analysis (UPGMA method). A SIMPER (SIMilarity PERcentage) analysis was done in order to know the contribution of the species in the similarity/dissimilarity within and between the same groups of samples. The ANOSIM test, through a "R ANOSIM" value which varies between 1 and -1 , indicates whether differences between groups are significant (R ANOSIM value approaching 1 or -1 ) or not (R ANOSIM value near 0). All these multivariate analyses were executed using the PRIMER6 software from Plymouth Marine Laboratory, UK (Clarke \& Warwick 1994).

Regarding biogeographic relationships, distributions were assessed using the abovementioned sources already used for species identifications, and also the Malacolog database (Rosenberg 2009) for occurrence in the Western Atlantic. Six broad areas (the Ibero Moroccan Gulf, Bay of Biscay, the Western margin of the British Isles including Hatton and Rockall banks, the Lusitanian seamounts, the Azores, and the slope of North America) were compared using presence/absence data and the Bray-Curtis similarity index, also using PRIMER6.

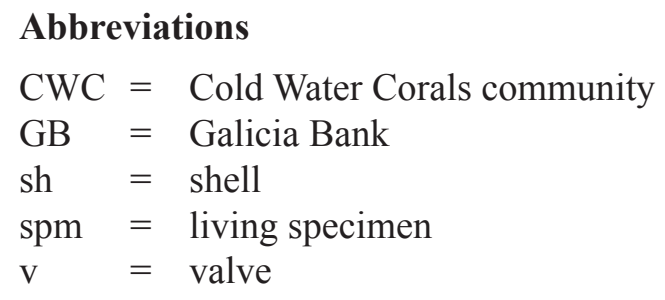

\section{Collections acronyms}

CER-MHNS = Emilio Rolán collection, now in Museo de Historia Natural, Santiago de Compostela, Spain

MNCN $=$ Museo Nacional de Ciencias Naturales, Madrid, Spain

MNHN $\quad=$ Muséum national d'Histoire naturelle, Paris, France

NHMUK = Natural History Museum, London, United Kingdom

\section{Results}

\section{Species diversity}

Table 2 is a list of the 212 species ( 6 of them only identified to genus level) known to occur at the Galicia Bank (1 monoplacophoran, 7 solenogastres, 3 polyplacophorans, 132 gastropods, 54 bivalves, 6 scaphopods, and 9 cephalopods). Four species (Anatoma corralae Gofas \& Luque sp. nov., Anekes spiralis Gofas \& Luque sp. nov., Ringicula crassidens Gofas \& Luque sp. nov., Acteocina interrogens Gofas \& Luque sp. nov.) are deemed new to science and described below, 34 species are recorded for the first time in Spanish waters (Table 2), of which 6 species were already stated as such by Gofas et al. (2017) based on the preliminary study of this material and thereby already included in the official list of marine organisms present in Spain, released in 2017. Another 20 species are recorded for the first time in the North Atlantic demarcation (NOR) of Spanish waters, of which 7 were already stated as such by Gofas et al. (2017). 


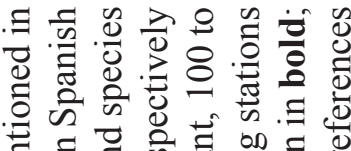

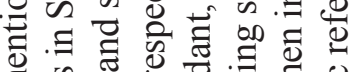

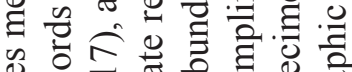
क

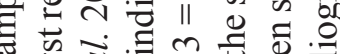

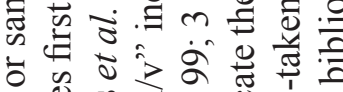
के

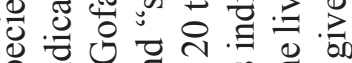

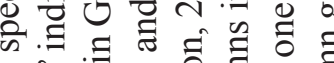

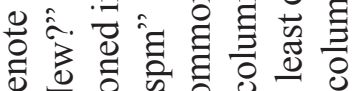

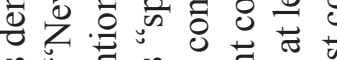

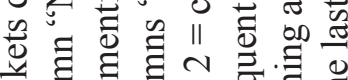

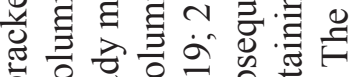

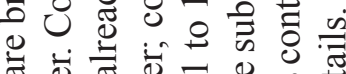

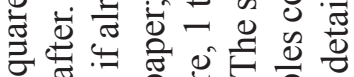
की

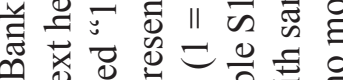

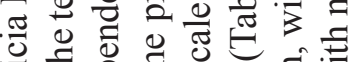
을 Ð

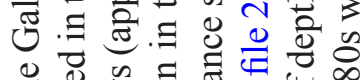
\&

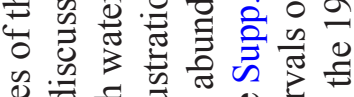

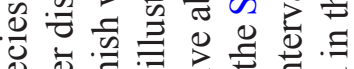

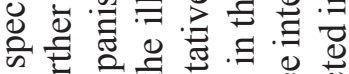
क

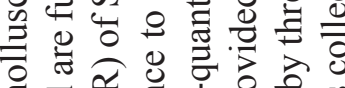

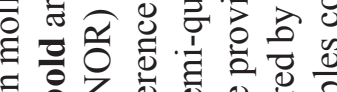

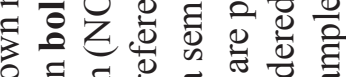

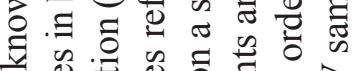

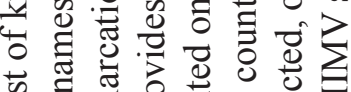

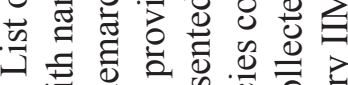
ज政 की

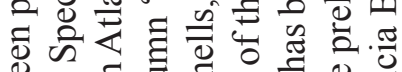

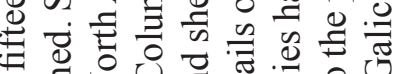

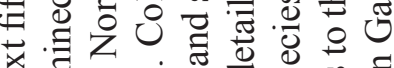

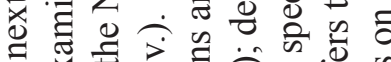

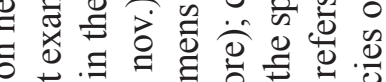

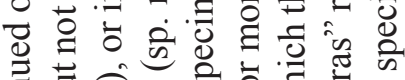

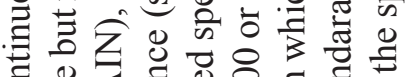

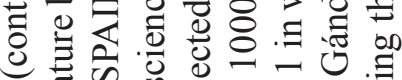
N

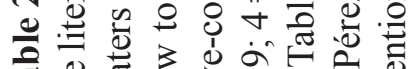

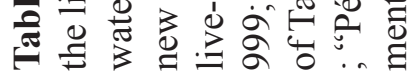

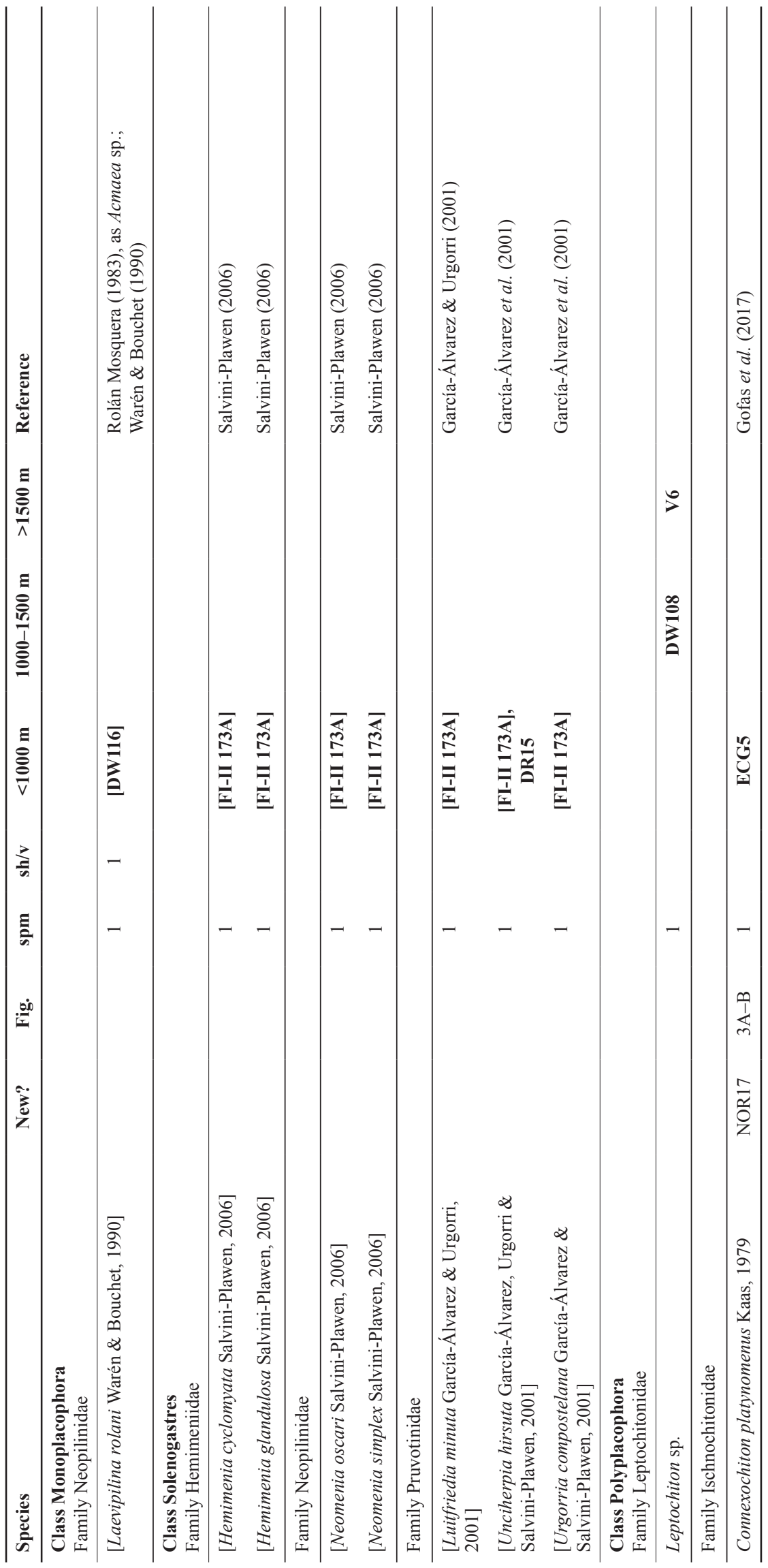




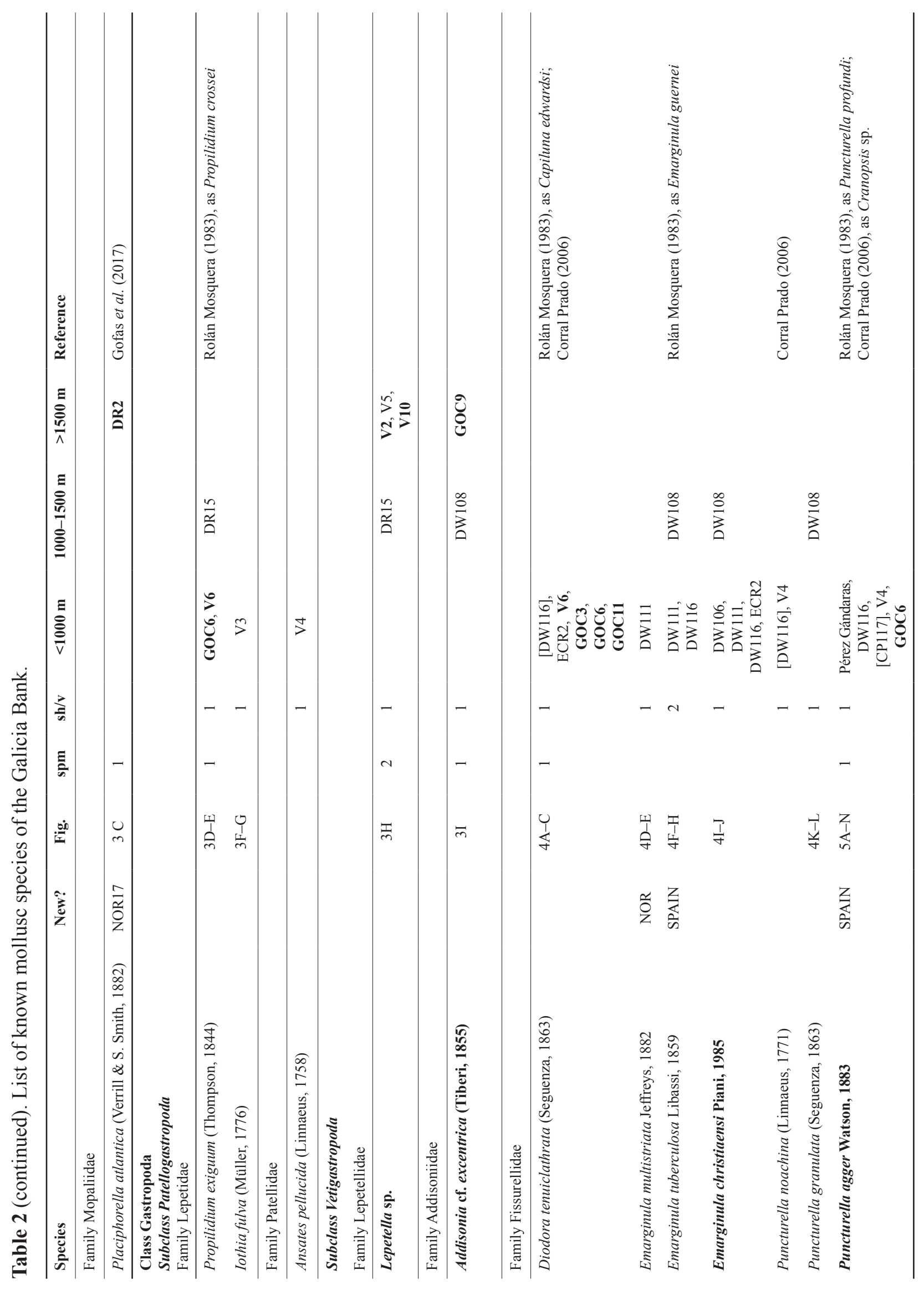




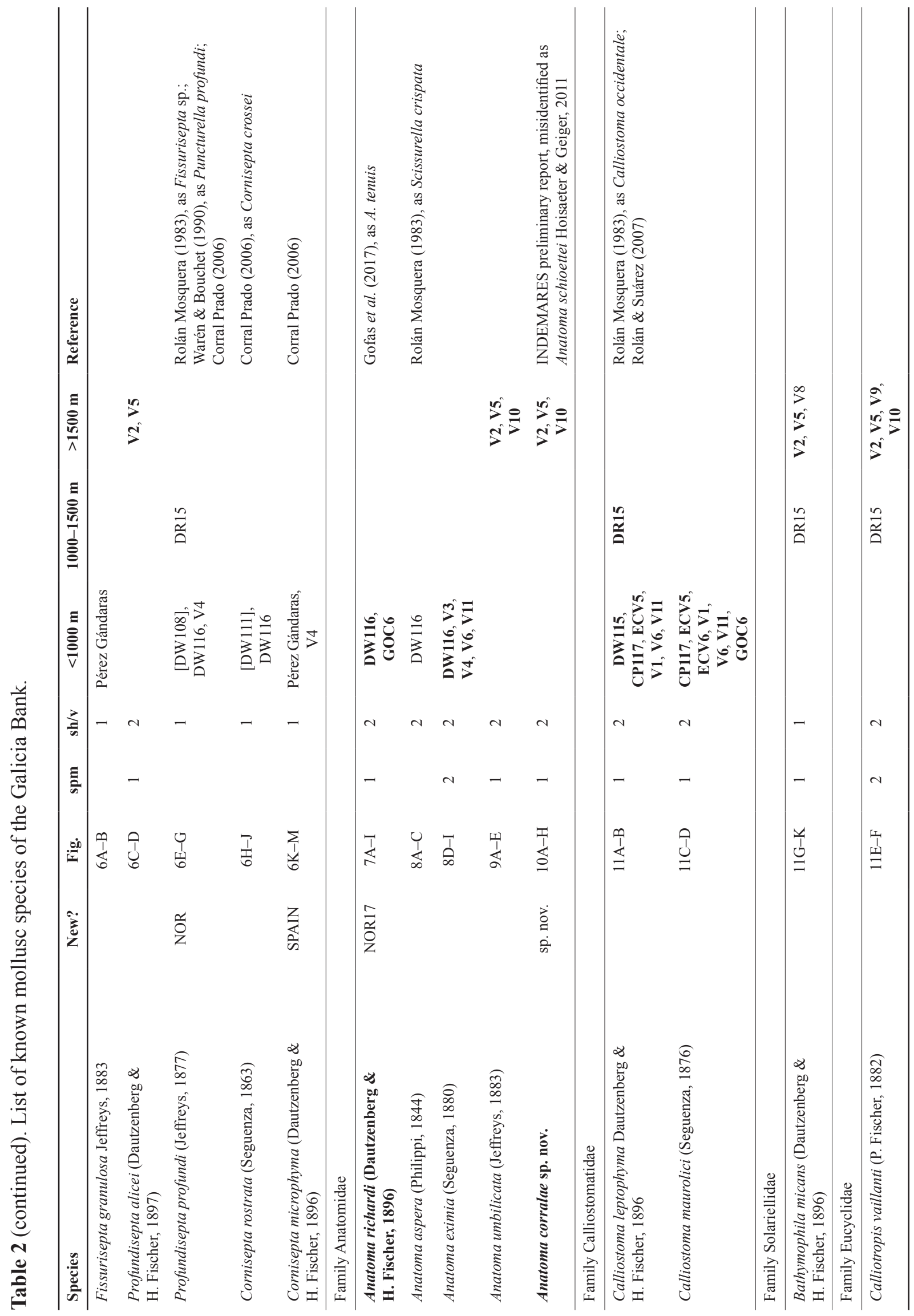




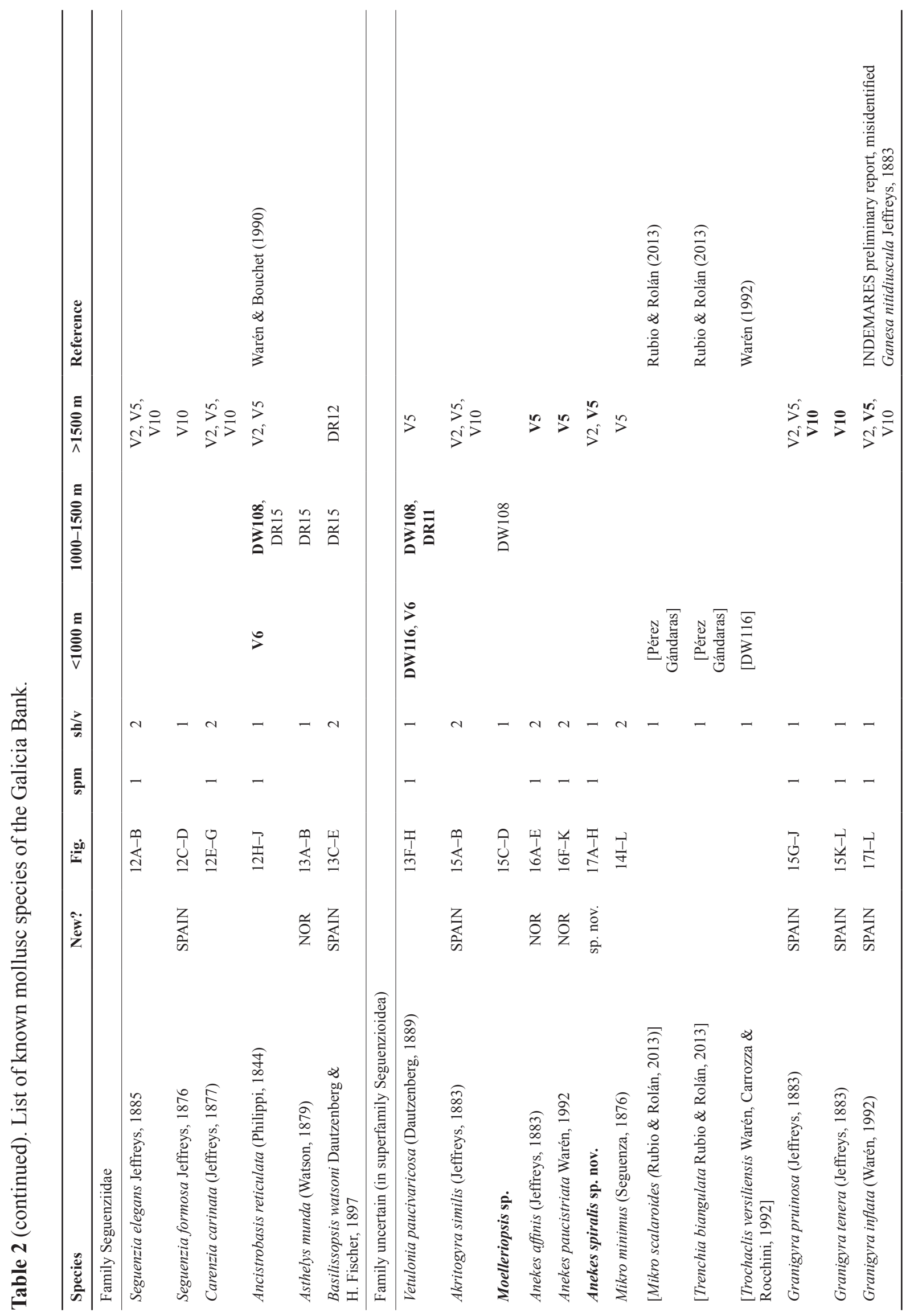




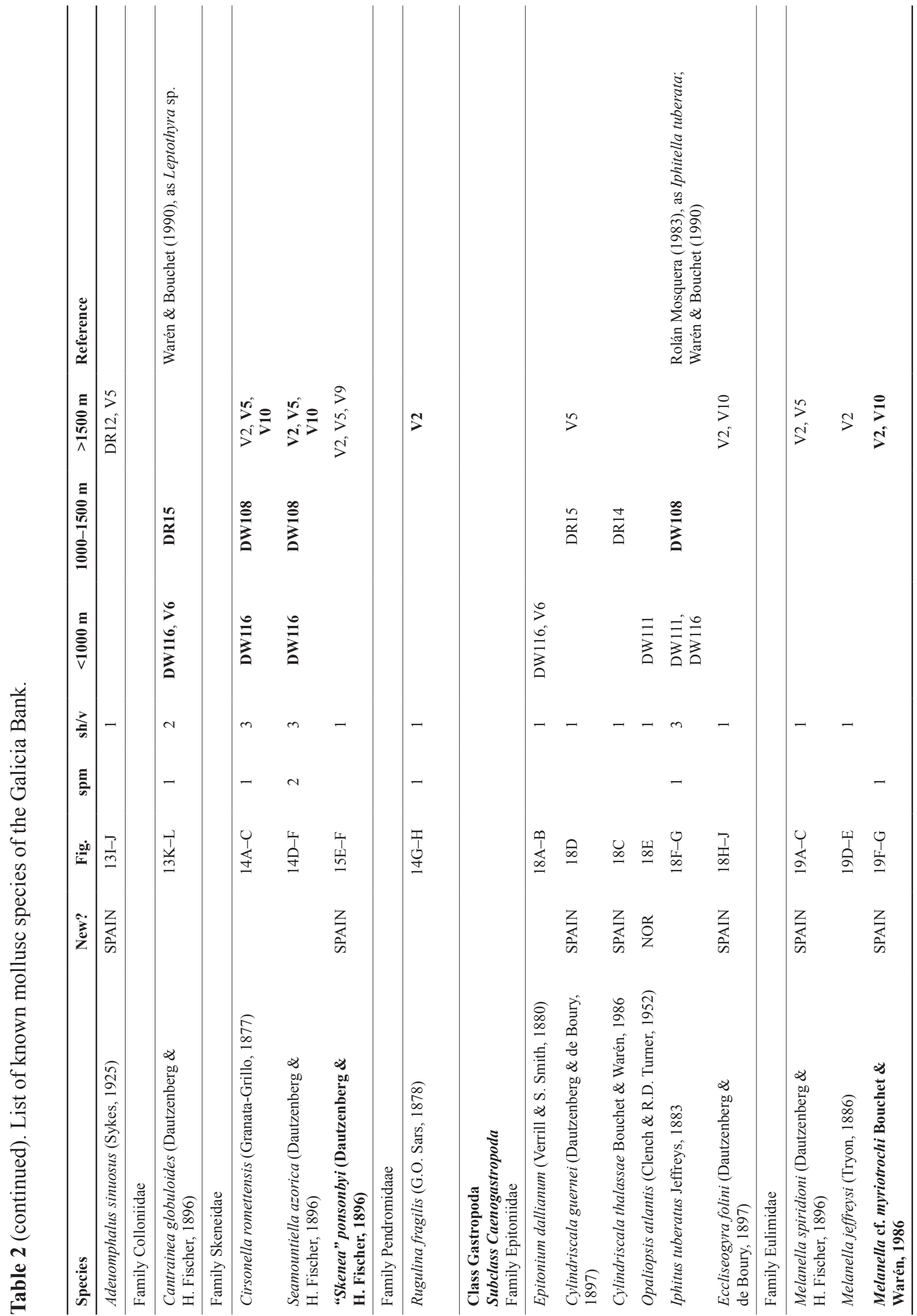




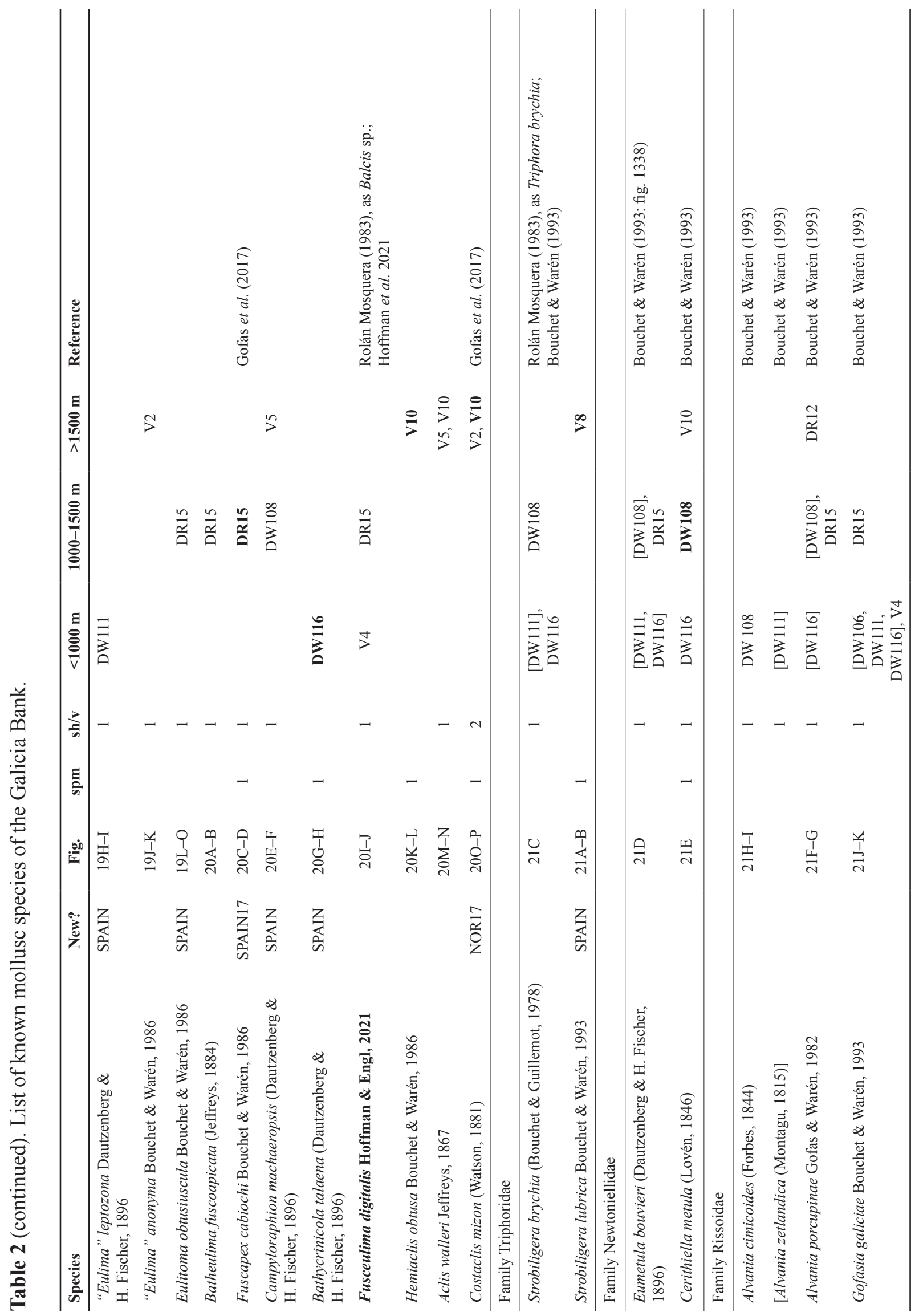




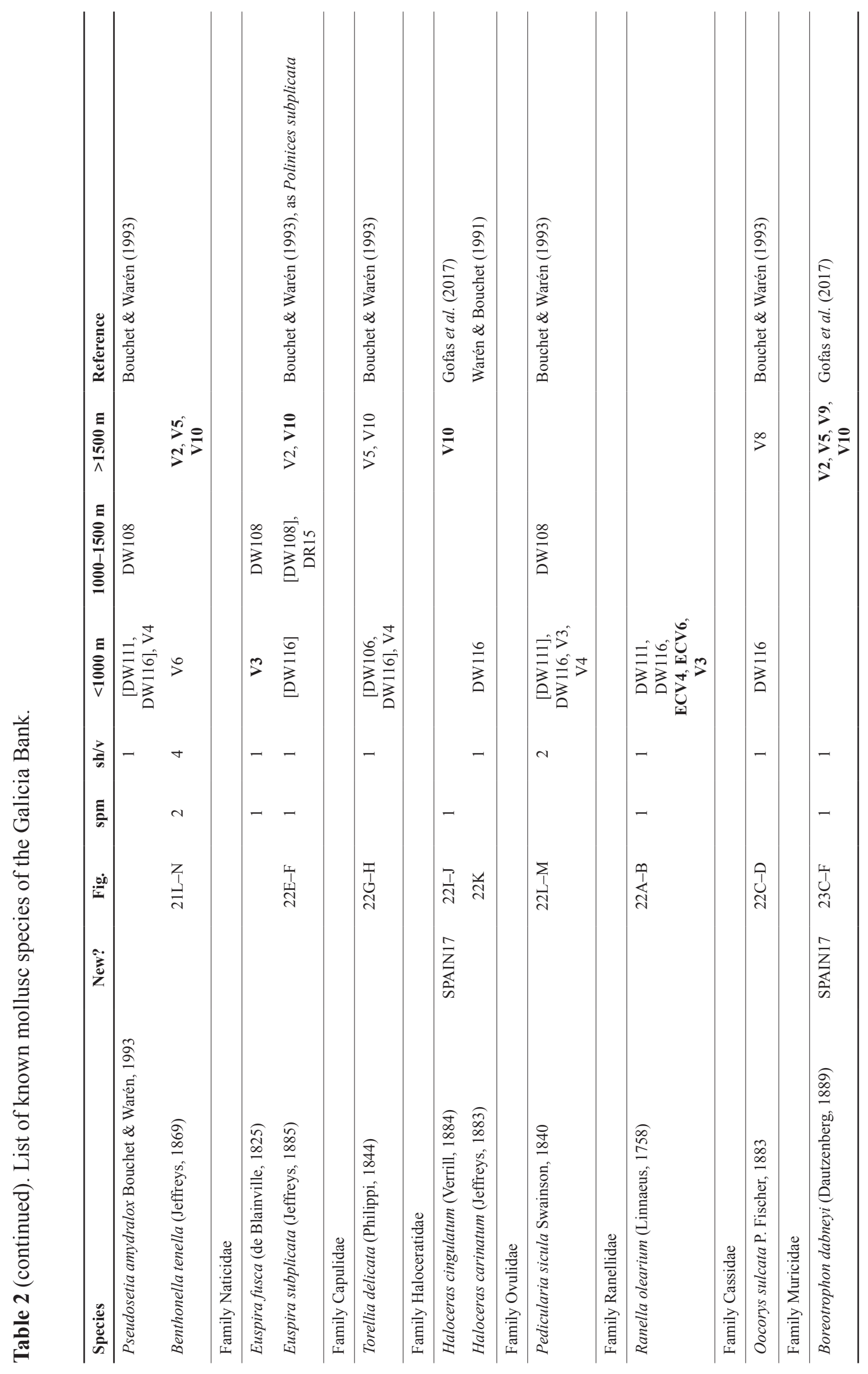




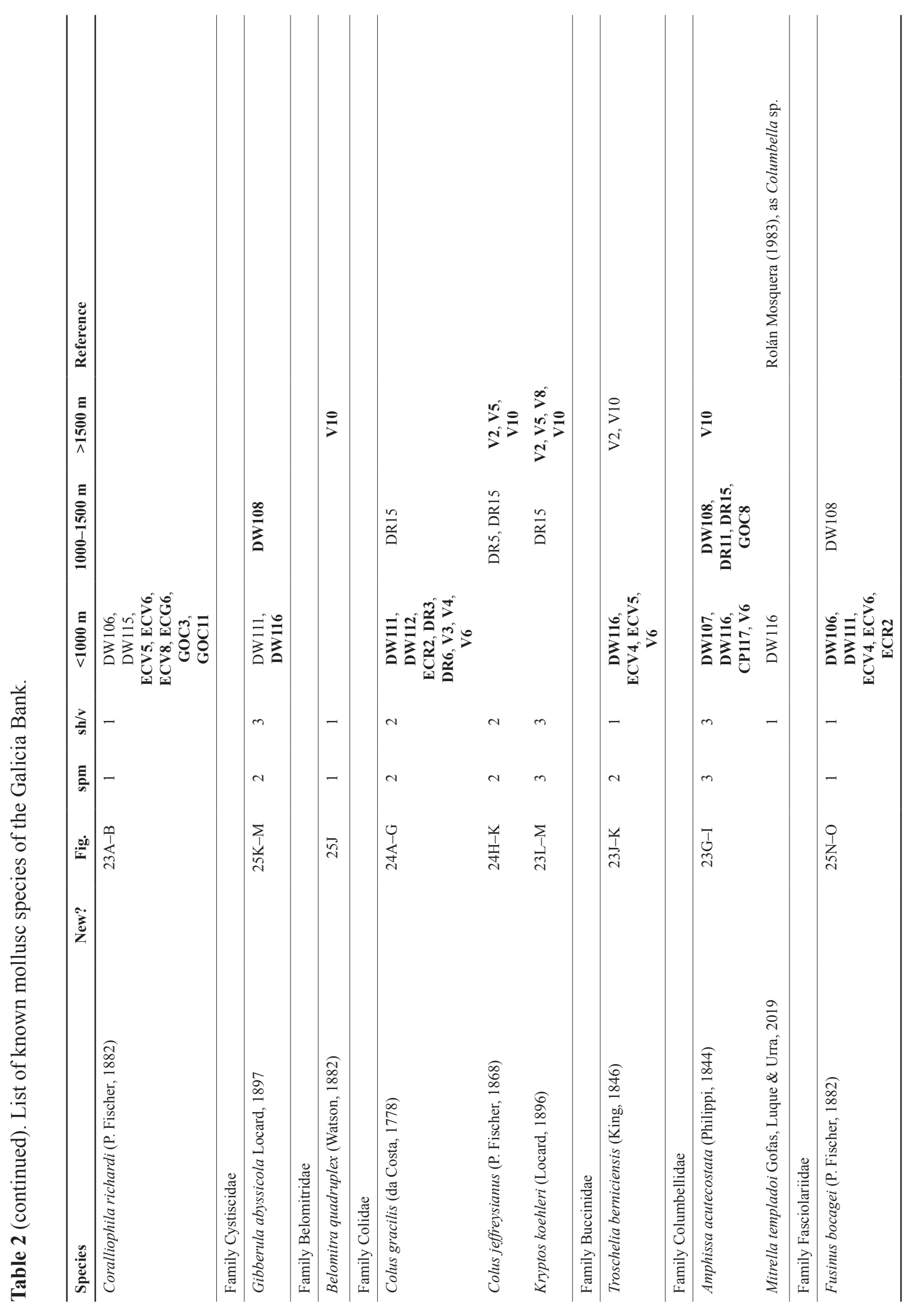




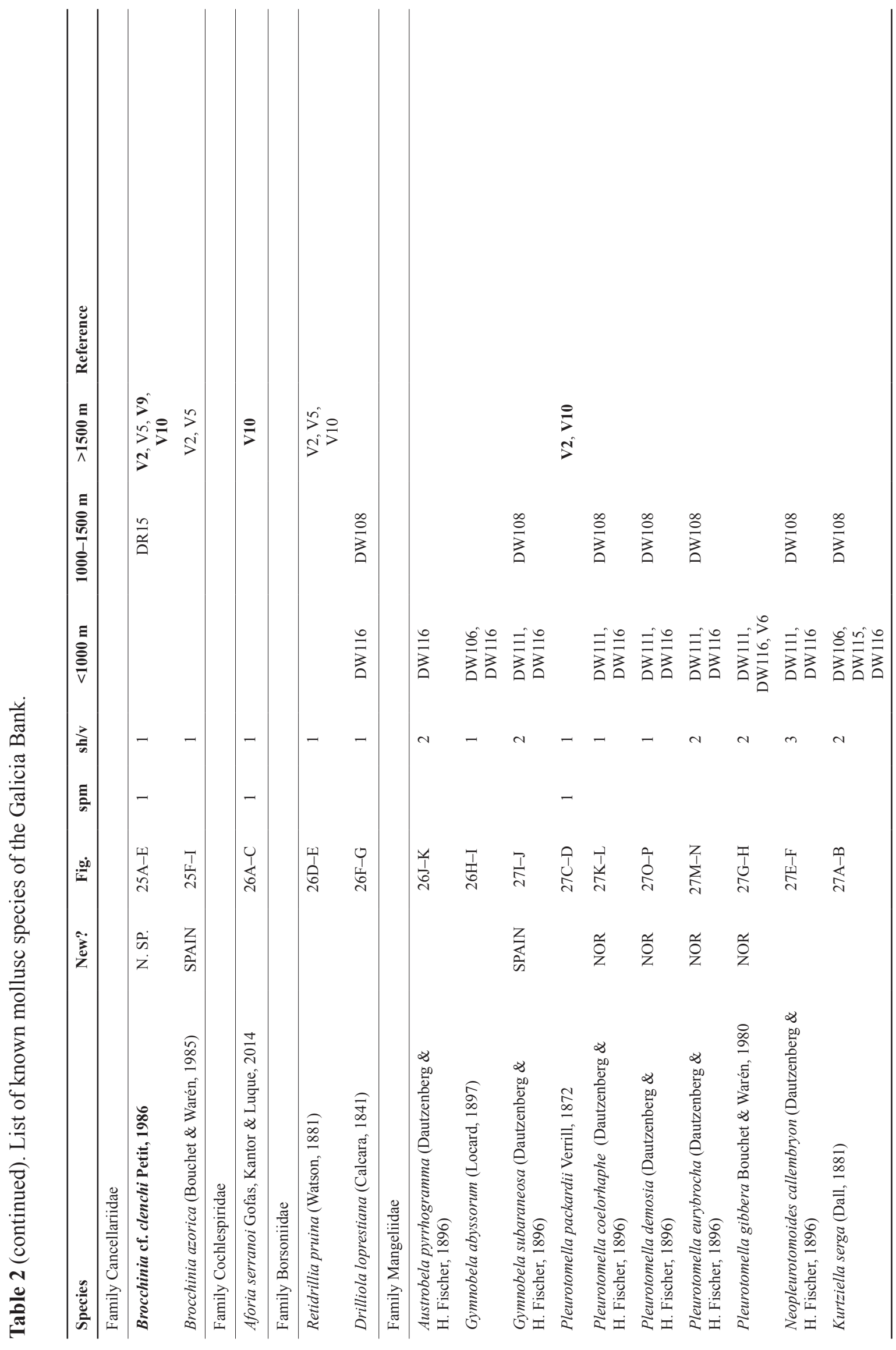




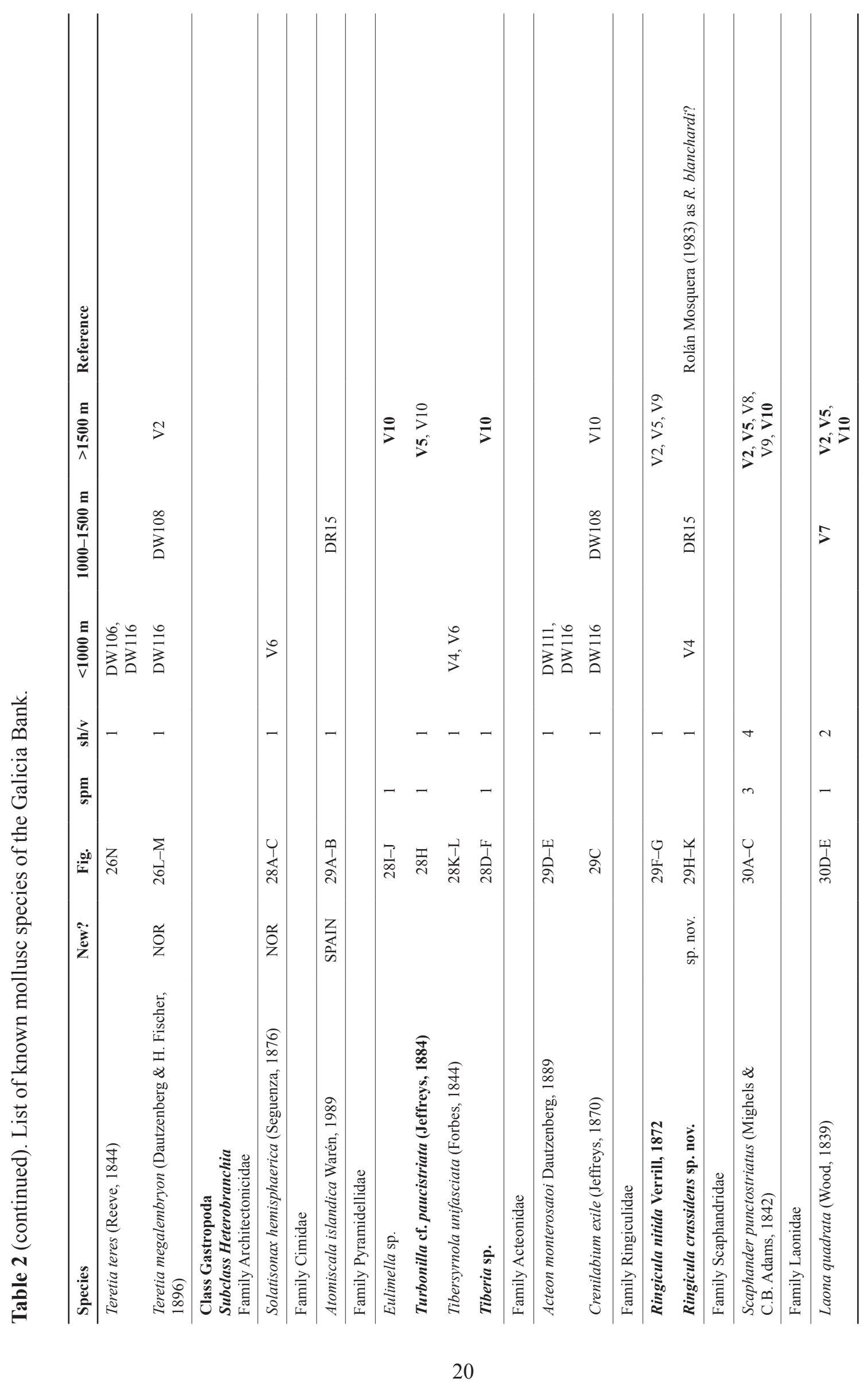




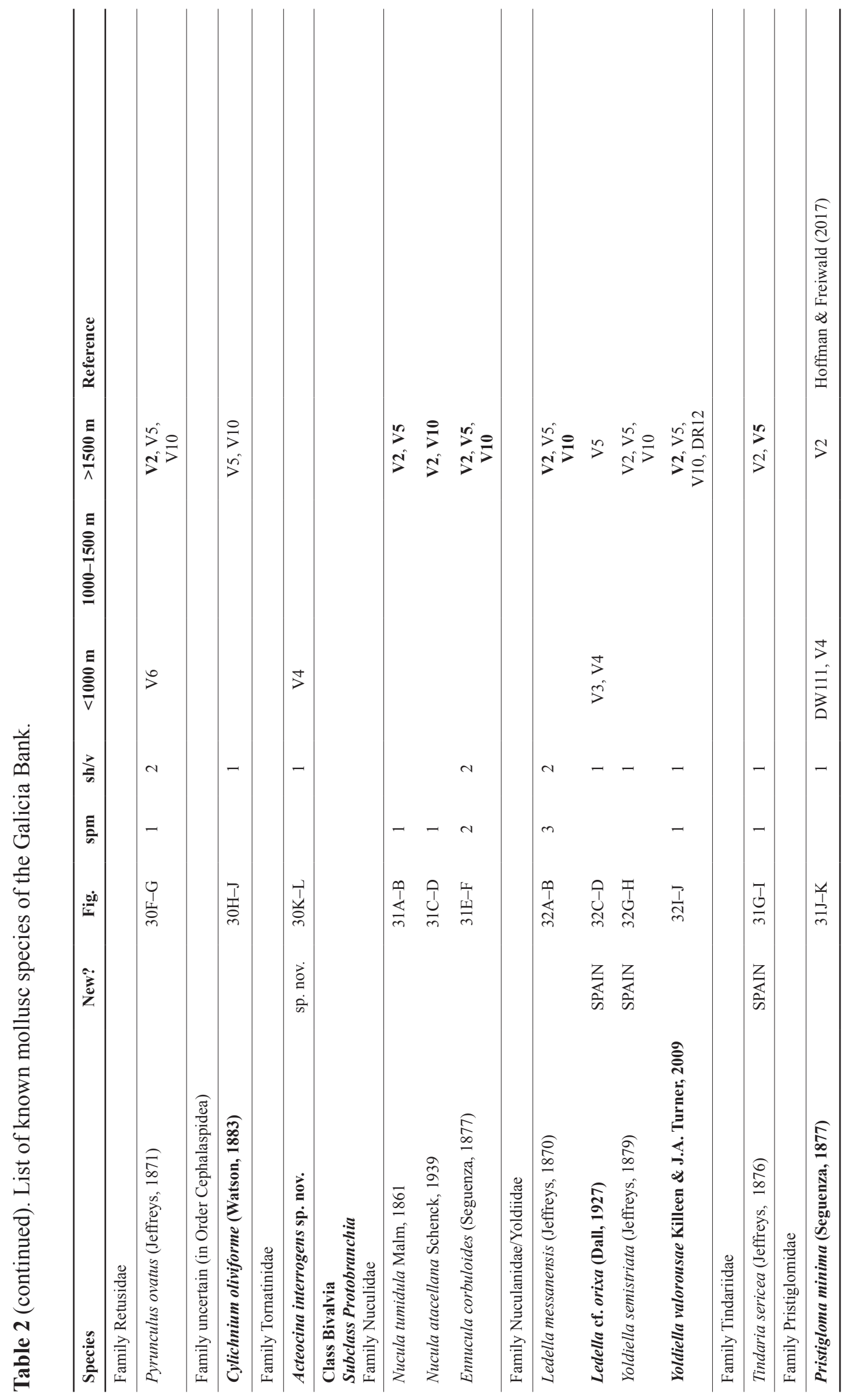




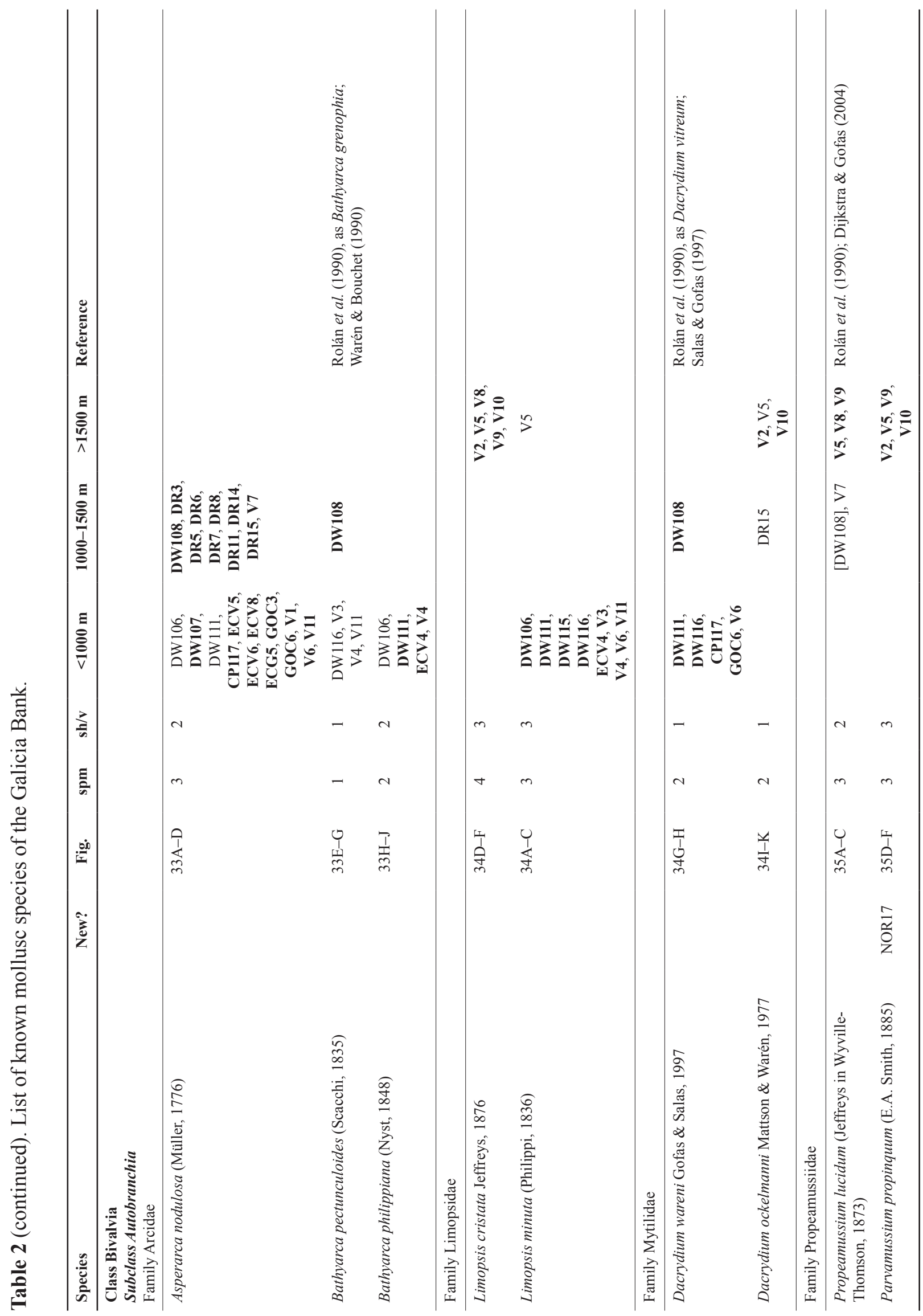




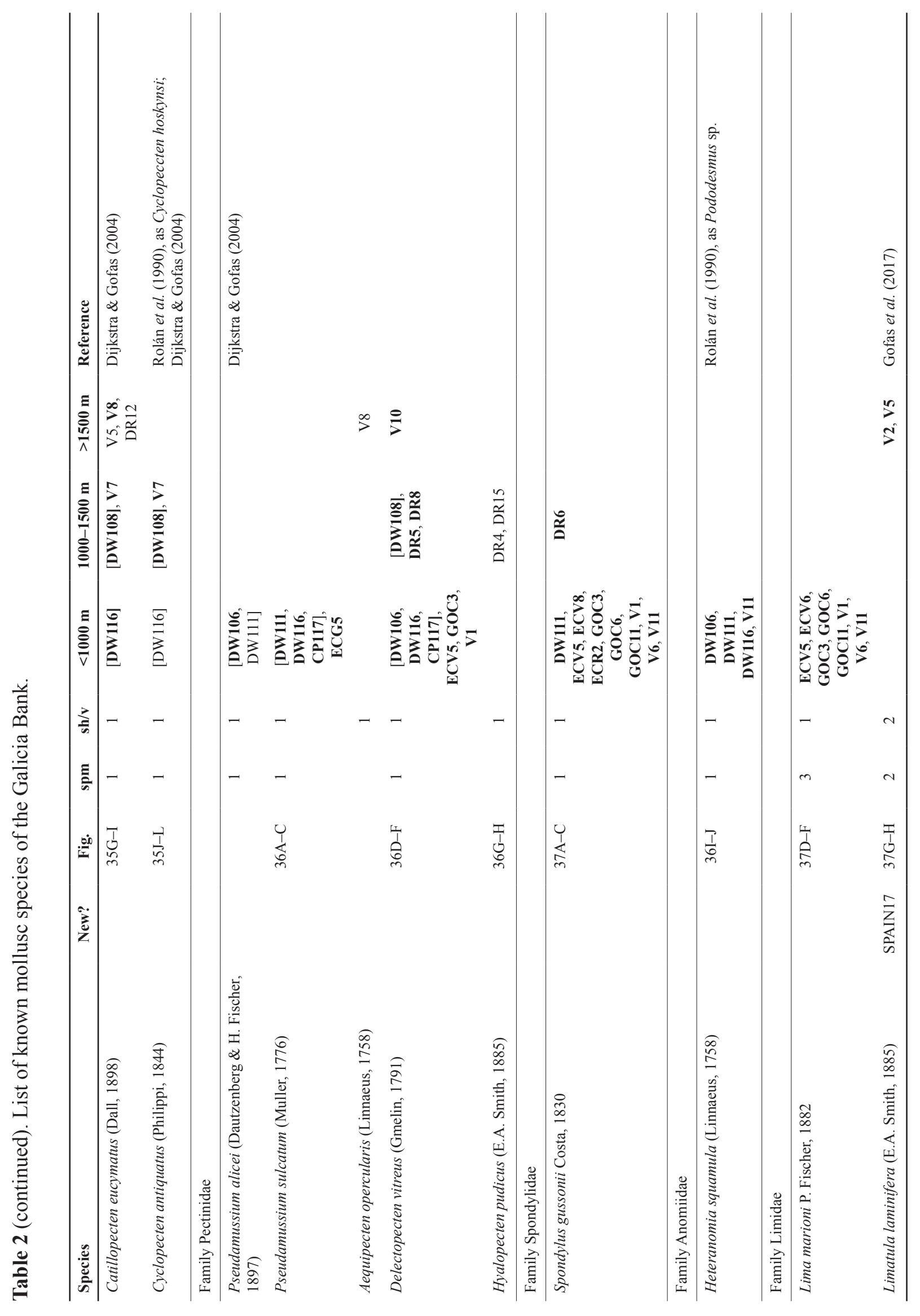




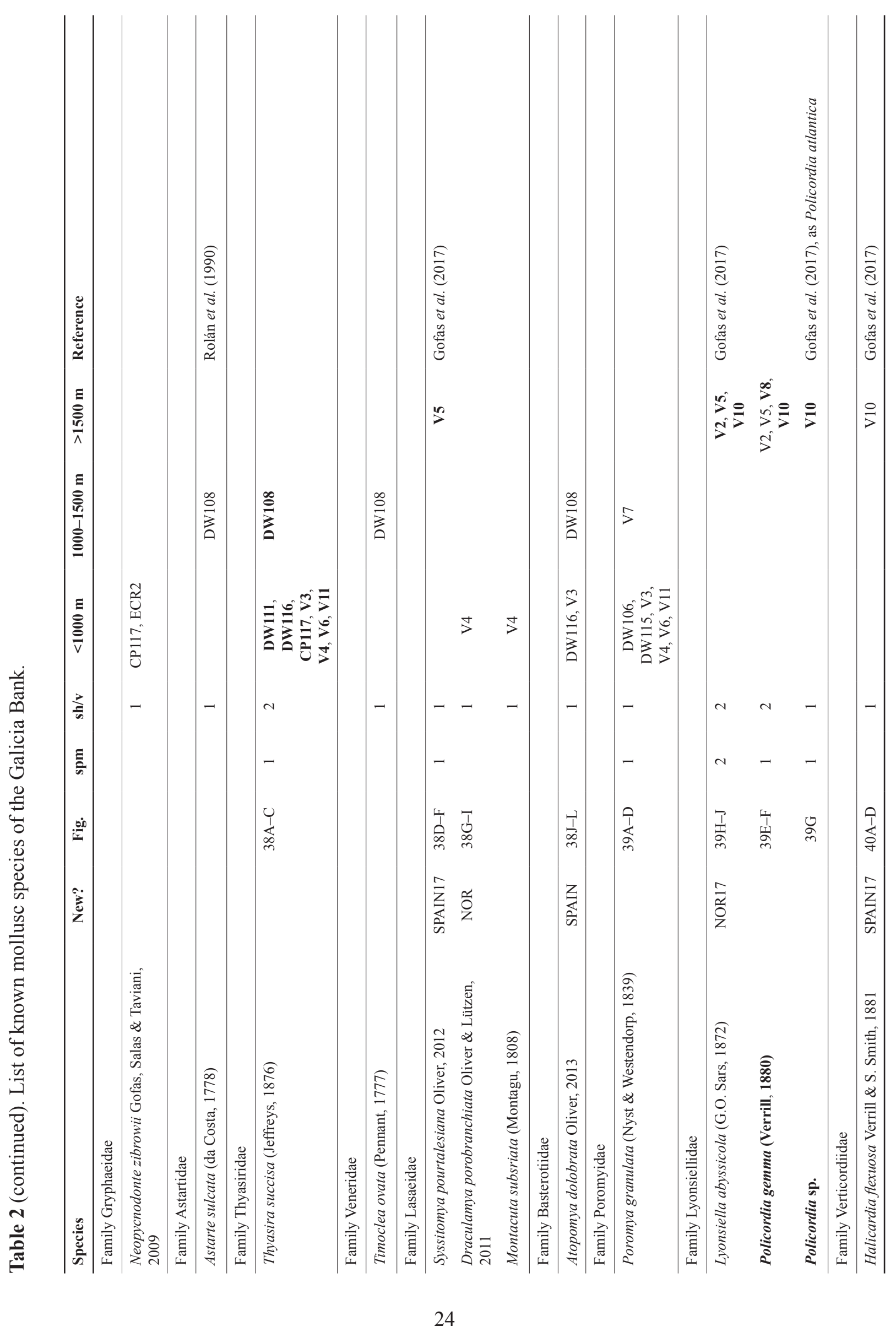




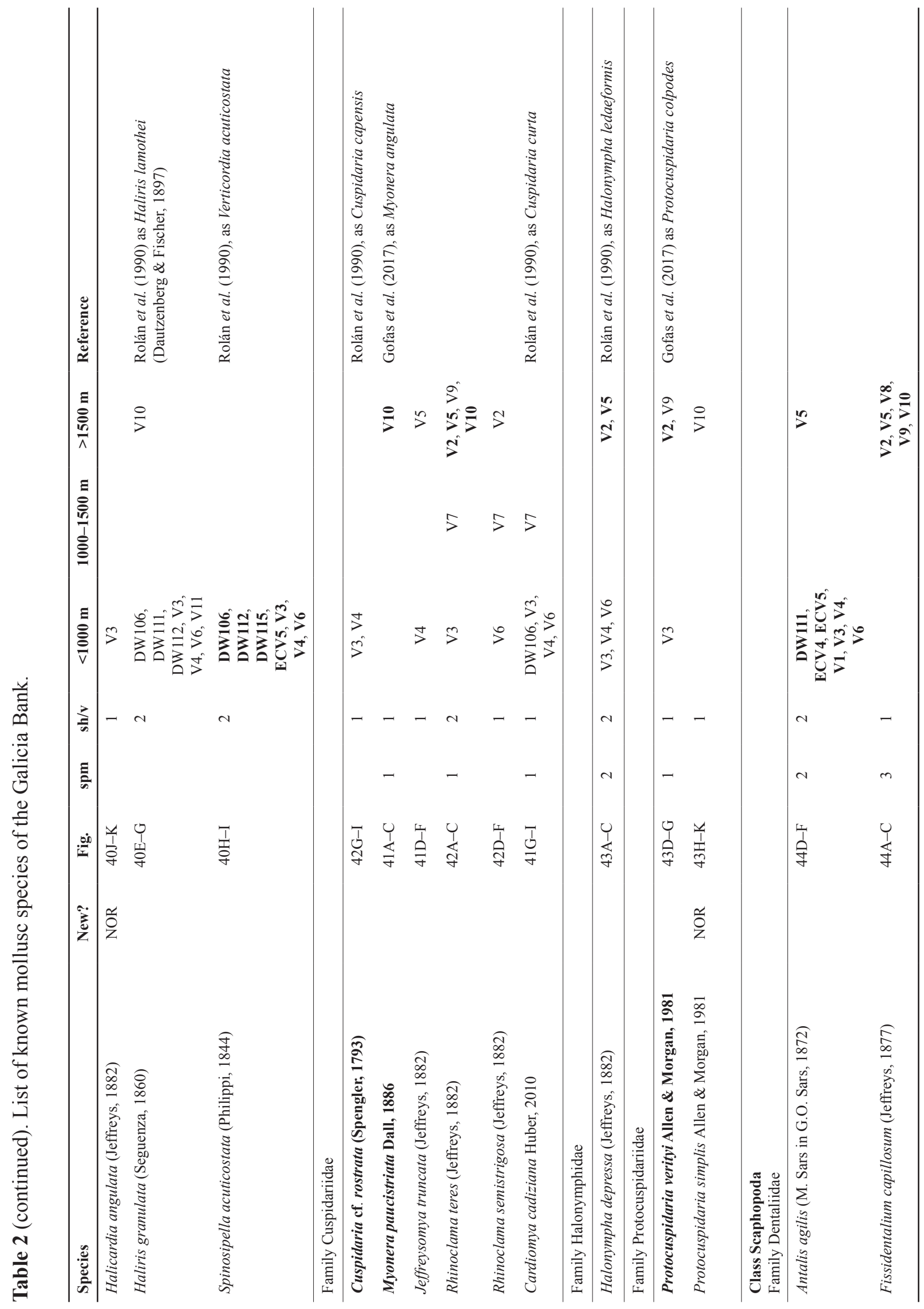




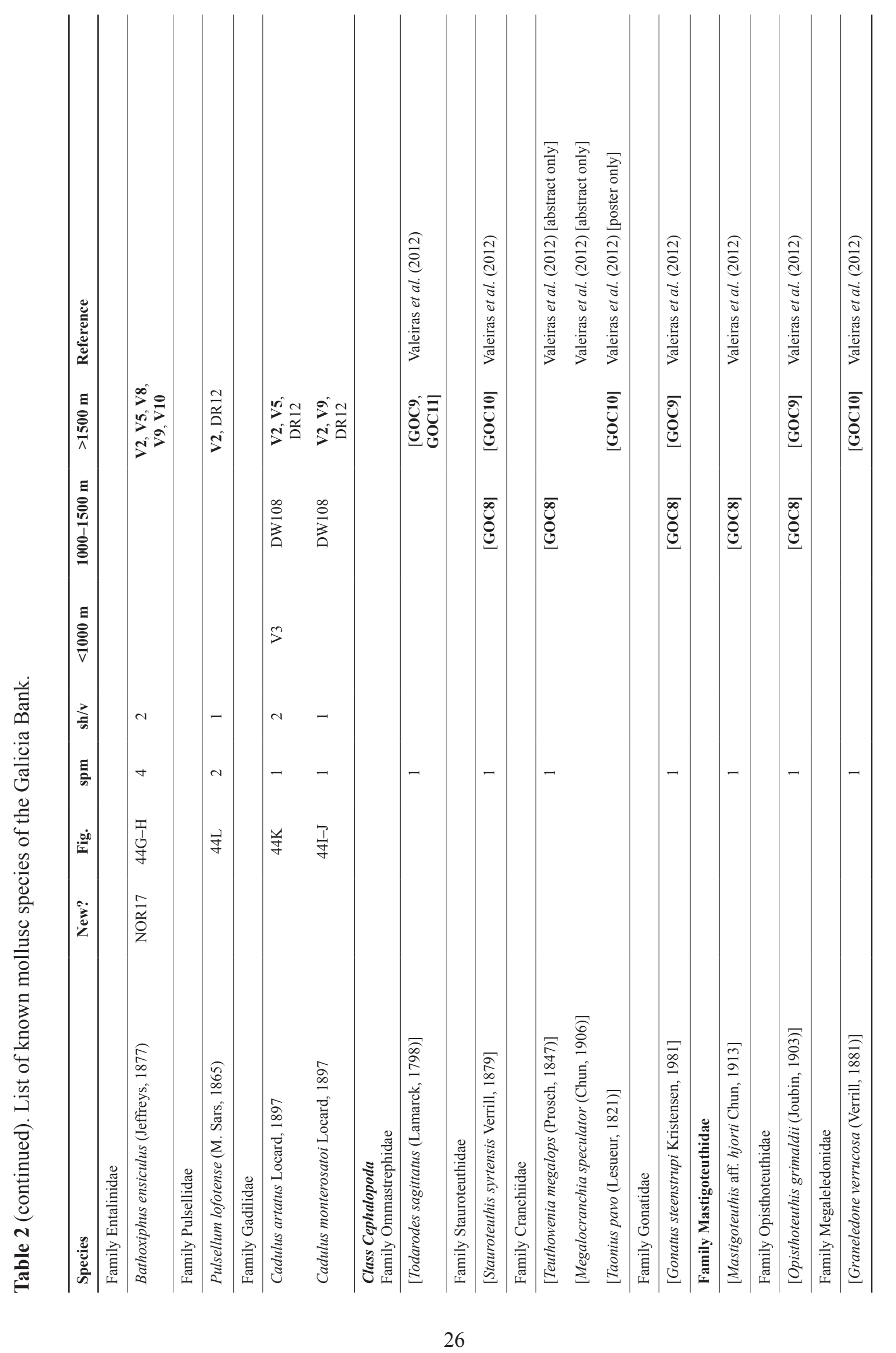


Samples examined for this study yielded over 7500 specimens collected alive, representing 104 species ( 99 identified at the species level, 5 at the genus level only), as well as a significant number of shells which were only scored on a semi-quantitative scale (Table 2). Of our material, there are 87 species represented by empty shells only, whereas eight species (the three Polyplacophora, and Strobiligera lubrica, Melanella cf. myriotrochi, Hemiaclis obtusa, Bathycrinicola talaena, Haloceras cingulatum) are only represented by one living specimen, or more (3 for Leptochiton sp., 2 for Melanella) but no shells.

Twenty one more species (Laevipilina rolani, the seven Solenogastres, Mikro scalaroides, Trenchia biangulata, Trochaclis versiliensis, Alvania zetlandica, and the nine Cephalopods) previously recorded (most of them based on the study of other SEAMOUNT 1 material and some from the FAUNA II cruise) were not represented in the material we examined.

The overlap between the species detected in the two main cruises (SEAMOUNT 1 and BANGAL 0711) is limited: 82 of the species examined were collected during SEAMOUNT 1, 160 during BANGAL 0711, and only 53 of these are shared. Most of the species are rare (scored "1" in Table 2) and 23 are represented by only one specimen or shell ("singletons").

Beam trawl samples from the survey listed in Table 1 revealed as the most efficient collecting gear for molluscs and for benthic macroinvertebrates in general, but specimens were also retrieved in most of the dredge and otter trawl samples.

\title{
Taxonomic notes, keys and new species descriptions
}

\author{
Phylum Mollusca Cuvier, 1795 \\ Class Gastropoda Cuvier, 1795 \\ Subclass Vetigastropoda Salvini-Plawen, 1980 \\ Family Lepetellidae Dall, 1882
}

Genus Lepetella Verrill, 1880

\section{Type species}

Lepetella tubicola Verrill \& S. Smith, 1880, by monotypy.

\section{Lepetella sp.}

Fig. $3 \mathrm{H}$

\section{Material examined}

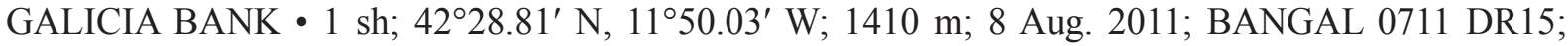
MNCN • $50 \mathrm{spm} ; 43^{\circ} 00.12^{\prime} \mathrm{N}, 11^{\circ} 57.67^{\prime} \mathrm{W} ; 1706 \mathrm{~m}$; 29 Jul. 2011; BANGAL $0711 \mathrm{~V} 2$; MNCN • $3 \mathrm{sh} ; 2^{\circ} 56.77^{\prime} \mathrm{N}, 1^{\circ} 58.53^{\prime} \mathrm{W}$; $1631 \mathrm{~m}$; 2 Aug. 2011; BANGAL $0711 \mathrm{~V} 5$; MNCN • $10 \mathrm{spm}, 40 \mathrm{sh}$; $42^{\circ} 41.87^{\prime} \mathrm{N}, 11^{\circ} 26.71^{\prime} \mathrm{W}$; $1720 \mathrm{~m}$; 8 Aug. 2011; BANGAL $0711 \mathrm{~V} 10$; MNCN.

\section{Remarks}

Numerous living specimens from 0.4 to $1.7 \mathrm{~mm}$ of a Lepetella species were found at depths of $1706 \mathrm{~m}$ (V2) and $1720 \mathrm{~m}$ (V10), attached to the external surface of empty tubes of the onuphid polychaete Hyalinoecia tubicola (Müller, 1776), which is common on deepest (1470-1809 m) sedimentary bottoms of the GB (Serrano et al. 2017a). Dantart \& Luque (1994), Lima et al. (2015) and Hoffman et al. (2019b) have described some new species of Lepetella in different areas of the Atlantic, and the latter authors mention the possible presence of the dubious taxon L. ionica Nordsieck, 1973 in the GB. Nevertheless, a comparative anatomical and molecular study of these deep-water specimens and specimens of NAtlantic shallower water species of Lepetella is necessary to ascertain if they belong to a different and perhaps undescribed species. 


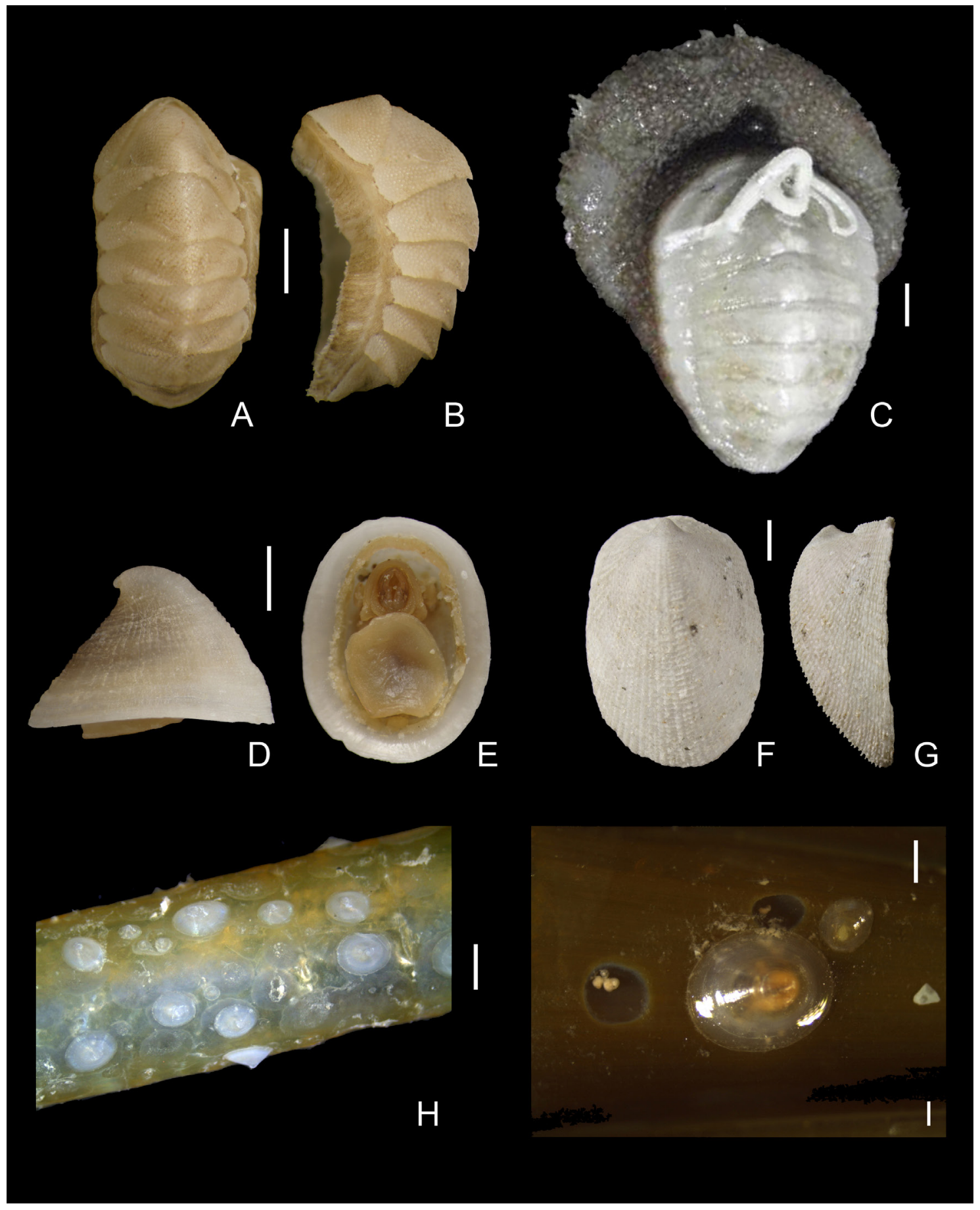

Fig. 3. Polyplacophora and Gastropoda (Patellogastropoda and Vetigastropoda Lepetelloidea). A-B. Connexochiton platynomenus Kaas, 1979, ECOMARG 0709, G5, 863 m, 4.8 mm. C. Placiphorella atlantica (Verrill \& S. Smith, 1882), BANGAL 0711, DR2, $1697 \mathrm{~m}, 10.3 \mathrm{~mm}$ (shipboard photograph by Pilar Ríos, IEO). D-E. Propilidium exiguum (Thompson, 1844), BANGAL 0711, V6, 909 m, $3.8 \mathrm{~mm}$. F-G. Iothia fulva (Müller, 1776), SEAMOUNT 1, DW116, 985-1000 m, 6.3 mm. H. Living Lepetella sp. on a tube of the polychaete Hyalinoecia tubicola (Müller, 1776), BANGAL 0711, V2, $1706 \mathrm{~m}$ (shipboard photograph). I. Two small (3.5 and $2.0 \mathrm{~mm}$ ) living specimens of Addisonia cf. excentrica (Tiberi, 1855) on the inside surface of an egg-capsule of Hydrolagus affinis (de Brito Capello, 1868), near two holes in the wall of the egg-capsule, BANGAL 0711, GOC9, $1683 \mathrm{~m}$ (shipboard photograph). Scale bars $=1 \mathrm{~mm}$. 
Family Addisoniidae Dall, 1882

Genus Addisonia Dall, 1882

\section{Type species}

Addisonia paradoxa Dall, 1882, by original designation.

Addisonia cf. excentrica (Tiberi, 1855)

Fig. 3I

Gadinia excentrica Tiberi, 1855: 13, pl. 2 figs 5-6.

Addisonia excentrica - Watson 1886: 32. — Locard 1898: 93.

\section{Material examined}

GALICIA BANK • $1 \mathrm{sh} ; 42^{\circ} 51^{\prime} \mathrm{N}, 1^{\circ} 53^{\prime} \mathrm{W}$; 1110-1125 m; 19 Oct. 1987; SEAMOUNT 1 DW108;

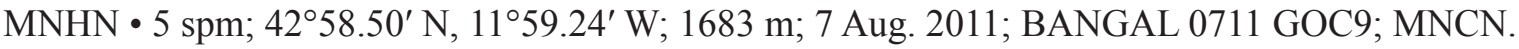

\section{Remarks}

Three living specimens $(3.5,3.4$ and $2.0 \mathrm{~mm})$ were found on the inside surface of an empty egg-capsule of the smalleyed rabbitfish, Hydrolagus affinis (de Brito Capello, 1868) (Holochephali, Chimaeridae). Two specimens $(3.5$ and $2.0 \mathrm{~mm}$ ) were attached close to small oval thinner areas or holes on the wall of the egg-capsule (Fig. 3I) caused by limpet rasping during feeding (Dantart \& Luque 1994). The shell and the external morphology of the living specimens resemble those of $A$. excentrica from shallower depths, but given their small size, further anatomical and molecular study is needed to identify them with certainty. As far as we know, this is the deepest record $(1683 \mathrm{~m})$ for living specimens of any Addisonia species. Living specimens of Addisonia excentrica were found down to 330-426 m in the Mediterranean (Dantart \& Luque 1994). The NW Atlantic Addisonia paradoxa (Dall, 1882), synonymized with A. excentrica by Dantart \& Luque (1994), was found alive by Dall (1882) from 110 to $293 \mathrm{~m}$, and McLean (1985) recorded it from 119 to $1170 \mathrm{~m}$, deepest records being probably shells. Addisonia enodis Simone, 1996, described from Brazil, was recorded alive down to $184 \mathrm{~m}$ (Simone 1996; Lima et al. 2016) and the NE Pacific A. brophyi McLean, 1985 from 155 to $174 \mathrm{~m}$ depth. Besides, this is the first record of an Addisonia species living inside a holocephalan egg-capsule. In addition to two empty eggcapsules (only one of them with Addisonia), three specimens ( 2 females and one male) of Hydrolagus affinis were caught in the same sample (Bañón et al. 2016).

Family Fissurellidae Fleming, 1822

Key to species of Fissurellidae found in the GB (see also Bogi \& Giusti 1994 for differentiating Emarginula spp.)

1. Anterior part of the aperture with a deep slit reaching the edge 2

- Anterior part of the aperture entire, shell with a slit or a hole not reaching the edge ....................... 4

2. Shell height $>$ half length, commarginal sculpture of tightly packed, vermiculate cordlets

Emarginula christiaensi Piani, 1985 (Fig. 4I-J)

- Shell height $\leq$ half length, commarginal cords elevated and narrower than intervals 3

3. Apex definitely overhanging the posterior edge of the shell

Emarginula tuberculosa Libassi, 1859 (Fig. 4F-H)

- Apex not overhanging the posterior edge of the shell

Emarginula multistriata Jeffreys, 1882 (Fig. 4D-E) 
4. Shell with a hole situated at the apex or close to it

- Shell with a slit situated between the apex and the anterior edge ................................................ 10

5. Apex retaining coiled part with larval shell, and the hole immediately anterior to it ..................... 6

- Apex without coiled part, with the hole situated on it ............................................................... 7

6. Shell height $>$ shell length, shell surface smooth

Profundisepta alicei (Dautzenberg \& H. Fischer, 1897) (Fig. 6C-D)

- Shell height $\leq$ shell length, radial sculpture of granulose riblets

Profundisepta profundi (Jeffreys, 1877) (Fig. 6E-G)

7. Shell usually large, with a sculpture of radial and commarginal riblets

Diodora tenuiclathrata (Seguenza, 1863) (Fig. 4A-C)

- Shell always smaller than $10 \mathrm{~mm}$ with a sculpture of minute granules

8. Granules arranged along radial lines ............... Fissurisepta granulosa Jeffreys, 1883 (Fig. 6A-B)

- Granules arranged quincuncially

9. Shell height nearly twice shell length Cornisepta rostrata (Seguenza, 1863) (Fig. 6H-J)

- Shell height about the same as shell length

Cornisepta microphyma (Dautzenberg \& H. Fischer, 1896) (Fig. 6K-M)

10. Shell sculpture formed by definite radial ribs intersecting commarginal cordlets

Puncturella asturiana (P. Fischer, 1882) [not found on GB]

- Shell sculpture formed by radial rows of granules, aligned to form ribs

11. Apex strongly curved, overhanging posterior edge

Puncturella granulata (Seguenza, 1863) (Fig. 4K-L)

- Apex weakly curved, not overhanging posterior edge

Puncturella agger Watson, 1883 (Fig. 5A-N)

Genus Emarginula Lamarck, 1801

\section{Type species}

Emarginula conica Lamarck, $1801=$ E. fissura $($ Linnaeus, 1758), by monotypy.

Emarginula christiaensi Piani, 1985

Fig. 4I-J

Emarginula elata Locard, 1898: 82-83, pl. 4 figs 16-18 (junior homonym of Emarginula elata Libassi, 1859) [figures erroneously called as pl. 4 figs $13-15$ in text and in plate caption].

Emarginula christiaensi Piani, 1985: 217-219, figs 65-67 (replacement name).

\section{Material examined}

GALICIA BANK • $1 \mathrm{sh} ; 42^{\circ} 42^{\prime} \mathrm{N}, 11^{\circ} 48^{\prime} \mathrm{W} ; 765 \mathrm{~m}$; 18 Oct. 1987; SEAMOUNT 1 DW106; MNHN • $2 \mathrm{sh} ; 42^{\circ} 40^{\prime} \mathrm{N}, 11^{\circ} 36^{\prime} \mathrm{W}$; 675-685 m; 19 Oct. 1987; SEAMOUNT 1 DW111; MNHN • $1 \mathrm{sh} ; 42^{\circ} 52^{\prime} \mathrm{N}$, $11^{\circ} 51^{\prime} \mathrm{W}$; $985-1000 \mathrm{~m}$; 20 Oct. 1987; SEAMOUNT $1 \mathrm{DW} 116$; MNHN $11 \mathrm{sh} ; 42^{\circ} 39.95^{\prime} \mathrm{N}, 11^{\circ} 36.42^{\prime} \mathrm{W}$; 615 m; 23 Jul. 2009; ECOMARG 0709 R2; MNCN. 


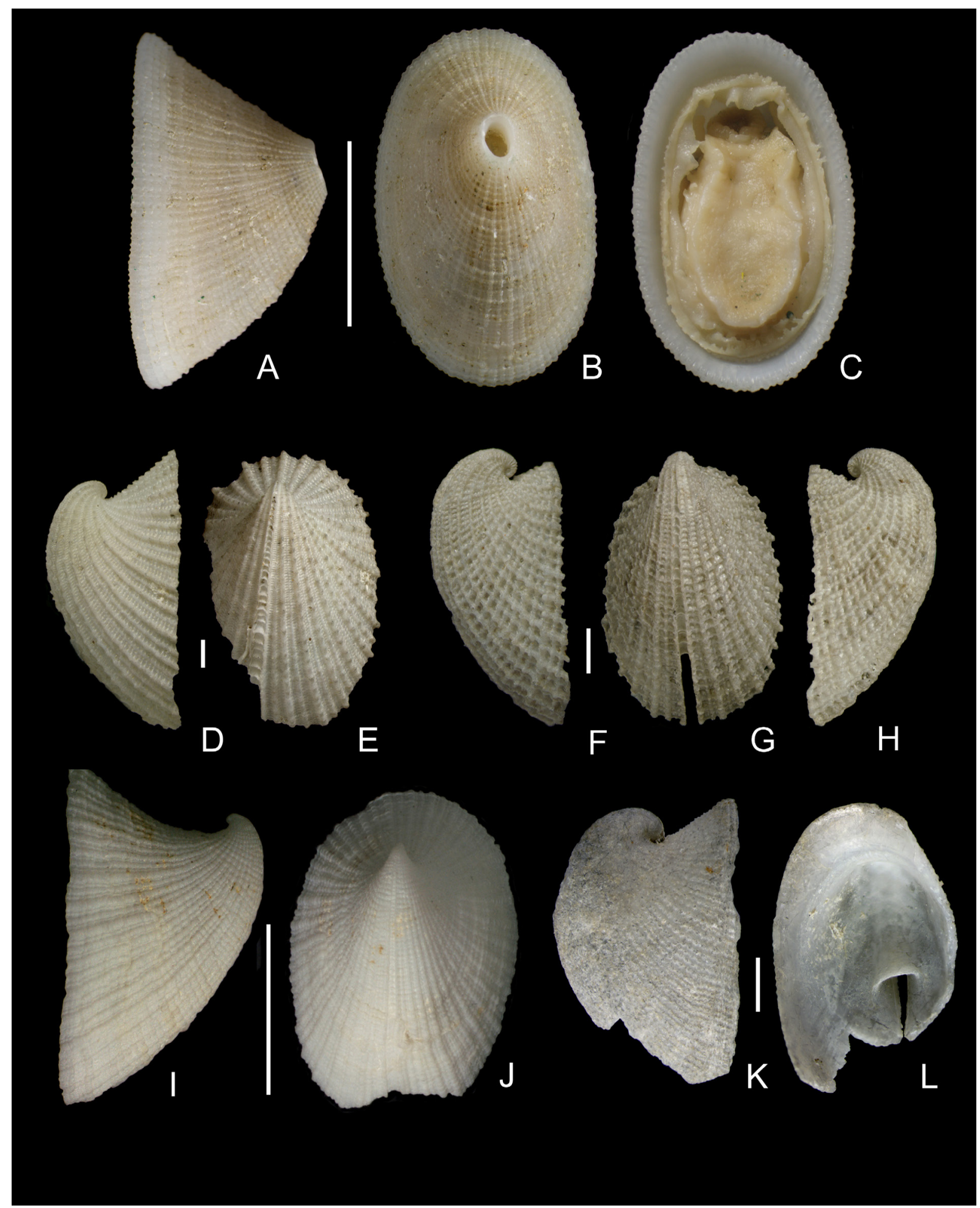

Fig. 4. Fissurellidae 1. A-C. Diodora tenuiclathrata (Seguenza, 1863), BANGAL 0711, GOC6, 903 m, 19.2 mm. D-E. Emarginula multistriata Jeffreys, 1882, SEAMOUNT 1, DW111, 675-685 m, $10.0 \mathrm{~mm}$. F-H. Emarginula tuberculosa Libassi, 1859, SEAMOUNT 1, DW116, 985-1000 m, $6.1 \mathrm{~mm}$. I-J. Emarginula christiaensi Piani, 1985, SEAMOUNT 1, DW106, 765 m, 20.0 mm. K-L. Puncturella granulata (Seguenza, 1863), SEAMOUNT 1, DW108, 1110-1125 m, $5.3 \mathrm{~mm}$. Scale bars: A-C, I-J = $10 \mathrm{~mm} ; \mathrm{D}-\mathrm{H}, \mathrm{K}-\mathrm{L}=1 \mathrm{~mm}$. 


\section{Remarks}

This species was never formally compared with Emarginula crassa Sowerby, 1813, described as a Pliocene fossil in the Crag of Ipswich (England) and reported in the Recent fauna of the British Isles and Scandinavia (Forbes \& Hanley 1850: 481) and off NW Spain in 748-1262 m (Dautzenberg \& Fischer 1897: 179). The latter species is differentiated by having a lower profile, with the apex more central and less curved backwards, and in having a more attenuated sculpture. In our experience, it has never been possible to differentiate the two species in the same locality, therefore they could represent at most geographical variants or subspecies of the same taxon. In the fossil record, Marquet (1995) separated subspecies Emarginula crassa crassa from E. crassa crassalta Wood, 1874, which is very similar, if not identical, to E. christiaensi. However, both forms did not coincide in the same geological formation. More recently, Hoffman \& Freiwald (2018) cited many empty shells of Emarginula christiaensi and two shells of E. crassa on the continental slope of Mauritania as if both were two different species, but they did not compare them and their figures do not show any differential character. The resolution of this taxonomic problem is beyond the scope of this work, but the name Emarginula crassalta Wood, 1874, would have priority if it were the same as Emarginula christiaensi.

Genus Puncturella Lowe, 1827

\section{Type species}

Patella noachina Linnaeus, 1771, by monotypy.

Puncturella agger Watson, 1883

Fig. 5A-N

Puncturella agger Watson, 1883: 32.

Puncturella agger - Watson 1886: 40, pl. 4 fig. 6.

Puncturella profundi (Jeffreys, 1877) - Rolán Mosquera \& Pérez-Gándaras 1981: 6, pl. 1 fig. 4. Rolán Mosquera 1983: 68.

Rimula granulata Seguenza, 1863 - Beck et al. 2006: 41. — Hoffman et al. 2011a: 90, pl. 108 figs 39-44. Cranopsis sp. - Corral Prado 2006: 27-30.

Cranopsis agger (Watson, 1883) - Barrio González 2015: 109-123, figs 32-34.

\section{Type material}

Syntype

VIRGIN ISLANDS • $1 \mathrm{sh}$ (Fig. 5J-L); off St. Thomas, north of Culebra Island; $18^{\circ} 38^{\prime} 30^{\prime \prime} \mathrm{N}, 65^{\circ} 5^{\prime} 30^{\prime \prime} \mathrm{W}$; 390 fathoms; 25 Mar. 1863; Challenger expedition, Station 24, coral-mud; NHMUK 1887.2.9.130.

\section{Material examined}

GALICIA BANK • $2 \mathrm{sh}$; 42 $52^{\prime} \mathrm{N}, 1^{\circ} 1^{\circ} 1^{\prime} \mathrm{W}$; 985-1000 m; 20 Oct. 1987; SEAMOUNT 1 DW116;

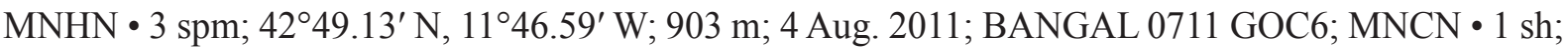

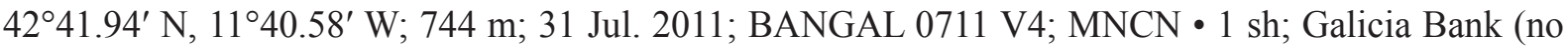
more details); 590-900 m; 1980-1981; G. Pérez-Gándaras, Instituto de Investigaciones Pesqueras de Vigo-CSIC leg.; CER-MHNS.

Description (based on material examined from GB)

Shell small (length $4.0 \mathrm{~mm}$, width $2.9 \mathrm{~mm}$, height $3.9 \mathrm{~mm}$ ), with an oval outline in apertural view, in lateral view with a conical profile, the apex located in the posterior $1 / 4$ and in the upper $1 / 3$ of the shell, curved towards the ventral side. Protoconch of one whorl, rounded, skewed to the right side, with a 


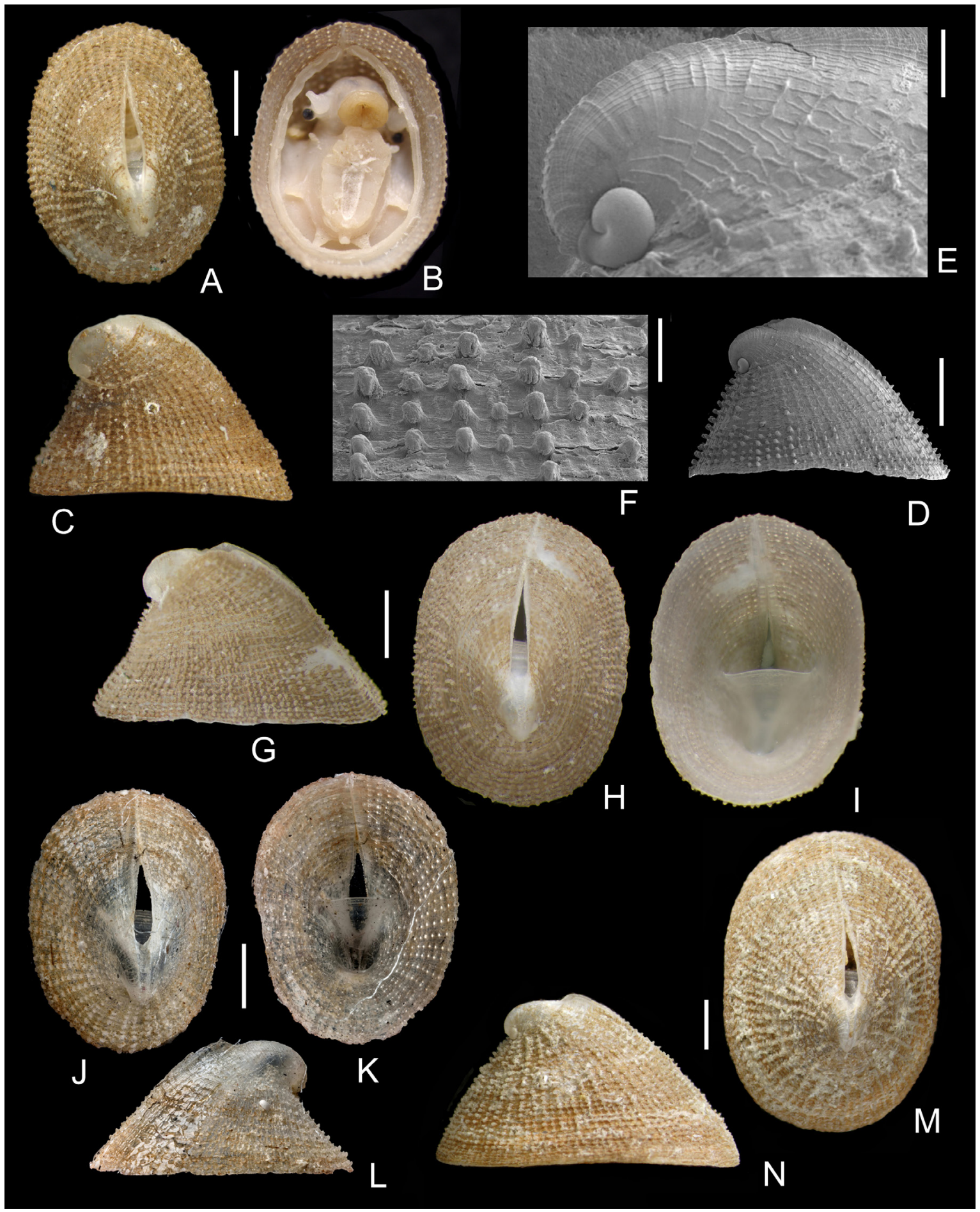

Fig. 5. Fissurellidae 2. Puncturella agger Watson, 1883. A-C. BANGAL 0711, GOC6, 903 m, 4.0 mm. D-F. SEAMOUNT 1, DW116, 985-1000 m, $4.0 \mathrm{~mm}$, SEM micrographs of protoconch and sculpture. G-I. SEAMOUNT 1, DW116, 985-1000 m, 4.4 mm. J-L. Syntype (NHMUK 1887.2 9.130), Challenger expedition, Station $24\left(18^{\circ} 38^{\prime} 30^{\prime \prime} \mathrm{N}, 65^{\circ} 5^{\prime} 30^{\prime \prime} \mathrm{W}\right)$ off Culebra Island, West Indies, 390 fathoms [713 m], 4.1 mm, courtesy and C NHMUK. M-N. Galicia Bank, campaigns 1980-1981 by Instituto de Investigaciones Pesqueras de Vigo-CSIC, 590-900 m, same specimen figured as Puncturella profundi (Jeffreys, 1887) in Rolán Mosquera \& Pérez-Gándaras (1981: 6, pl. 1 fig. 4), and Rolán Mosquera (1983: 68), $6.0 \mathrm{~mm}$. Scale bars: A-D, G-M = $1 \mathrm{~mm}$; E-F = $200 \mu \mathrm{m}$. 


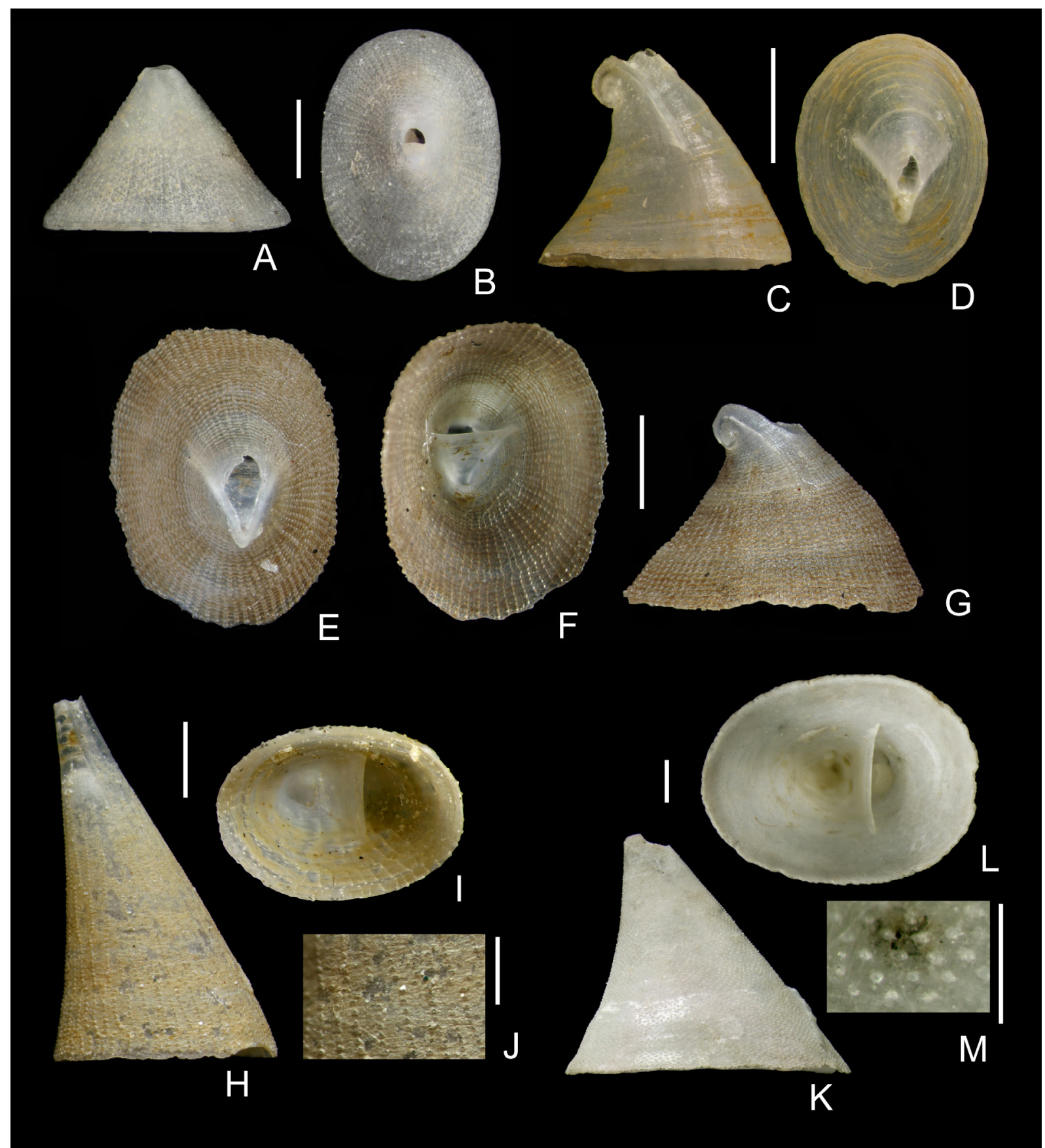

Fig. 6. Fissurellidae 3. A-B. Fissurisepta granulosa Jeffreys, 1883. Galicia Bank, 590-900 m, shell figured in Rolán Mosquera \& Pérez Gándaras (1981), $3.2 \mathrm{~mm}$. C-D. Profundisepta alicei (Dautzenberg \& H. Fischer, 1897), BANGAL 0711, V5, $1631 \mathrm{~m}, 2.2 \mathrm{~mm}$. E-G. Profundisepta profundi (Jeffreys, 1877), SEAMOUNT 1, DW116, 985-1000 m, $3.2 \mathrm{~mm}$. H-J. Cornisepta rostrata (Seguenza, 1863), SEAMOUNT 1, DW116, 985-1000 m, 4.8 mm height. K-M. Cornisepta microphyma (Dautzenberg \& H. Fischer, 1896), BANGAL 0711, V4, $744 \mathrm{~m}, 5.6 \mathrm{~mm}$ height. Scale bars: A-I, K-L = $1 \mathrm{~mm}$; J, M = $500 \mu \mathrm{m}$. 
diameter ca $245 \mu \mathrm{m}$ (Fig. 5E). Selenizone small but well marked, narrower than the foramen, bordered by a smooth and slightly raised rim. Foramen elongate, narrowing anteriorly to a sharp point, located dorsally in the highest part of the shell, bordered on each side by a flange that continues that of the selenizone; width of the foramen $9 \%$ of the width of the shell; length $30 \%$ of the length of the shell. In front of the foramen, there is a double rib along which the two halves of the shell meet. Sculpture almost absent in the initial coiled part, then mainly constituted by small pustules, aligned along a median thread to form radial cords (Fig. 5F). The width of the interspaces between radial cords is equivalent to or somewhat greater than the thickness of the pustules, and the interval between pustules along a cord is less than the diameter of the pustules. In the abapical half of the shell, appear additional radial cords that grow rapidly in thickness until the primary cords are matched. There are around $80-90$ radial cords reaching the growth edge of the shell, of which one-third was added in the abapical half. The pustules are also connected by fine, irregular commarginal lamellae. Aperture oval, contained in a plane, with its edge denticulated by the termination of the cords. Inner surface smooth, shiny, with a groove running from the foramen to the anterior edge. Large internal septum (one third of the total length of the shell), with sharp and almost straight anterior edge, concealing more than half of the foramen in apertural view.

\section{Distribution}

The type locality of Puncturella agger is Challenger station 24, off north of Culebra Island, Puerto Rico. It was subsequently recorded from Florida, Cuba and Mexico by Pérez Farfante (1947). Living specimens and shells are known from NW Galicia and Galicia Bank, shells only from Meteor, Hyères, Irving, Plato, Atlantis and Josephine seamounts (Corral Prado 2006, as Cranopsis sp.; Barrio González 2015, as Cranopsis agger (Watson, 1883)), and shells recorded as Rimula granulata Seguenza, 1863, from Ampère, Seine and Sedlo seamounts (Beck et al. 2006) and Rockall Bank (Hoffman et al. 2011a), see under remarks. The species has therefore an amphiatlantic distribution.

\section{Remarks}

This species has been reported from different locations in the northeast Atlantic with names which we consider wrong. Rolán Mosquera \& Pérez-Gándaras (1981: 6, pl. 1 fig. 4) and Rolán Mosquera (1983: 68) recorded and illustrated for the first time one specimen from the Galicia Bank, misidentified as Puncturella profundi Jeffreys, 1877, which is a different species currently named Profundisepta profundi (Jeffreys, 1877), (see Fig. 6E-G herein). The specimen figured in the aforementioned papers is illustrated again here (Fig. 5M-N).

The shell figured by Micali \& Villari (1989: figs 1-4) as Rimula granulata Seguenza, 1863, from the Pleistocene of Salice (Sicily) is somewhat similar to P. agger, but clearly differs in having an extremely inflated profile, with an apex much more anterior and much more curved towards the ventral edge so as to be situated near the half of the total height of the shell (in the upper third in Puncturella agger). The sculpture of this fossil species is also different, with the radial rows of tubercles all of similar size and thicker than the spaces between rows. An old shell, possibly subfossil, collected from the Galicia Bank (Fig. 4K-L) could represent the real Puncturella granulata, since it agrees in profile and sculpture with the original description and illustration of Rimula granulata by Seguenza (1863: 88, figs 6, 6a). Watson (1883:31) reported and described a specimen of "Puncturella (Cranopsis) granulata, Seg. [tuberculata n. sp.]", also collected in the type locality of Puncturella agger (Challenger Sta. 24). However, it is not clear whether this identification is correct since Watson's (1886: 46, pl. 4 fig. 5) illustration is a copy of Seguenza's (1863: fig. 6) and he described his specimen as "peculiarly long and narrow" which does not fit the original description. This identification was nevertheless assumed by Pérez Farfante (1947: 125-126, pl. 54 figs 4-7) who also considered that Puncturella watsoni Dall, 1889 was the same as P. (C.) granulata sensu Watson $(1883,1886)$. Puncturella watsoni is also very close to the Western Atlantic Puncturella larva Dall, 1927 (see Pérez Farfante 1947). 
Further specimens of Puncturella agger from SEAMOUNT 1 DW116 were recorded in Eva Corral's unpublished undergraduate project (Corral Prado 2006) as Cranopsis sp. Later, Lucia Barrio in her PhD Thesis (Barrio González 2015) described and illustrated as Cranopsis agger (Watson, 1883) a large amount of material (32 specimens and 362 shells) collected in several cruises from different localities of NW Galicia and several NE Atlantic seamounts (see under distribution).

Puncturella fornicata Locard, 1898, a valid species never reported since its original description from off Western Sahara, $782 \mathrm{~m}$ (Locard 1898: 78-79, pl. 5 figs 1-3), is somewhat similar to $P$. granulata in profile but with definite radial ribs as in $P$. asturiana and $P$. noachina.

None of the eight western Atlantic species of Cranopsis described and illustrated by Simone \& Cunha (2014) is identical to Puncturella agger. Cranopsis canopa Simone \& Cunha, 2014 is somewhat similar in profile and in having a relatively small septum, but it differs from $P$. agger in having fewer and broader axial ribs (46 versus up to 90 in $P$. agger), uniform axial ribs ( $P$. agger usually has larger and smaller ribs intercalated), and the ventro-anterior edge of the septum concave, while in P. agger it is convex.

Family Anatomidae McLean, 1989

Genus Anatoma Woodward, 1859

\section{Type species}

Scissurella crispata Fleming, 1828, by monotypy.

Key to the species of Anatoma found in the GB (see also Geiger 2012)

1. Last whorl very broad, about $40 \%$ of diameter in apical view; suture of last whorl along selenizone or just below it Anatoma richardi (Dautzenberg \& H. Fischer, 1896) (Fig. 7A-I)

- Last whorl less than $35 \%$ of diameter in apical view, suture definitely situated at a distance beneath selenizone

2. Umbilicus wide and deep, its diameter more than $10 \%$ of the shell diameter, adapical surface nearly smooth except for growth lines Anatoma umbilicata (Jeffreys, 1883) (Fig. 9A-E)

- Umbilicus less than $10 \%$ of the shell diameter, surface of shell with distinct sculpture of axial riblets and spiral threads

3. Selenizone situated high on the profile, making it stepped; adapical part of the whorl above it forming a shoulder and abapical part below it very convex ... Anatoma eximia (Seguenza, 1880) (Fig. 8D-I)

- Selenizone situated near the middle of the last whorl, not as above 4

4. Sculpture of conspicuous axial riblets, profile between suture and selenizone distinctly convex ....... Anatoma aspera (Philippi, 1844) (Fig. 8A-C)

- Sculpture of tenuous ribs, profile between suture and selenizone rather flat Anatoma corralae Gofas \& Luque sp. nov. (Fig. 10A-H)

Anatoma richardi (Dautzenberg \& H. Fischer, 1896)

Fig. 7A-I

Scissurella richardi Dautzenberg \& H. Fischer, 1896: 487; pl. 21 figs 2-3.

Anatoma richardi - Geiger 2012: 1108. — Ortega \& Gofas 2019: 518-519. 


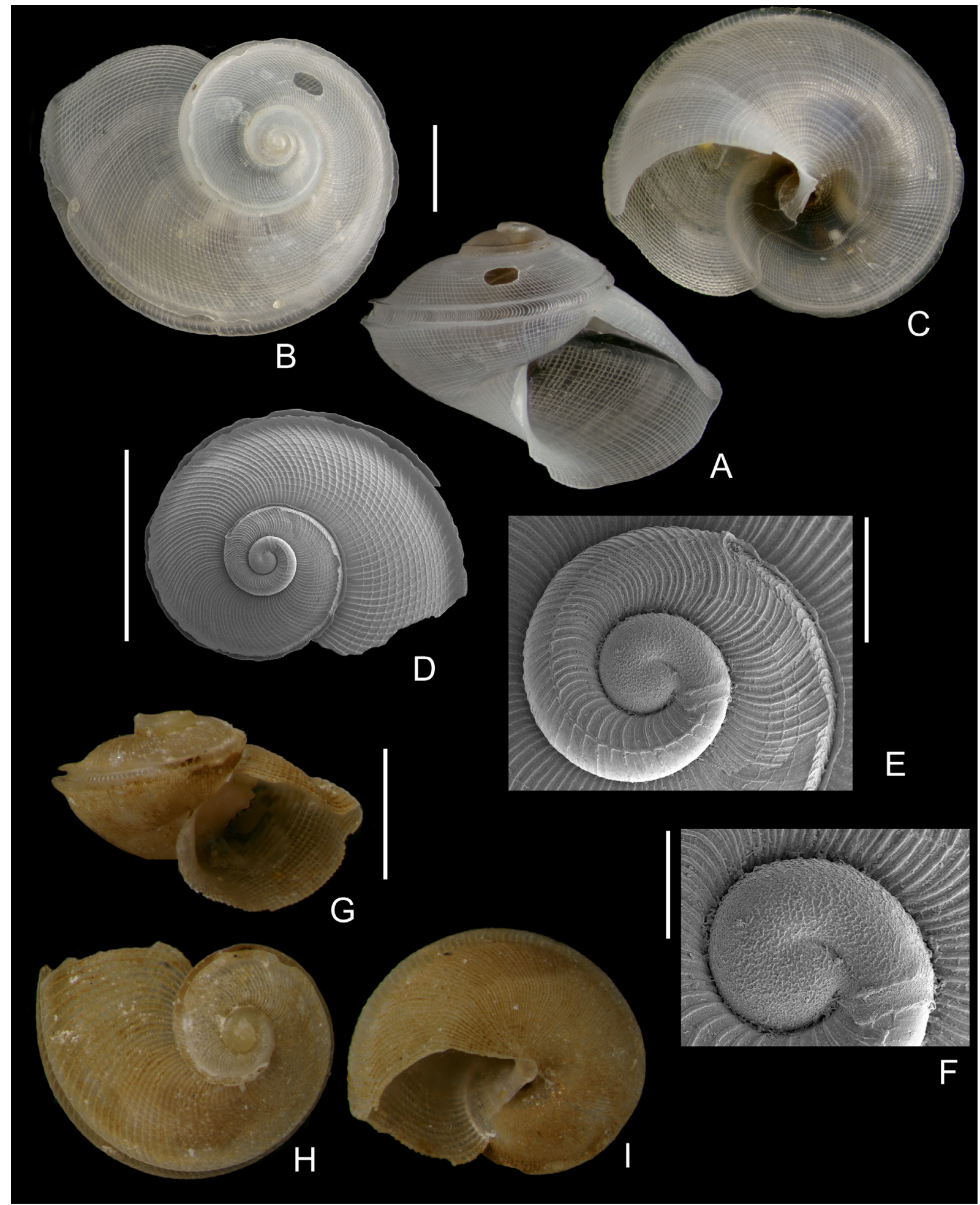

Fig. 7. Anatomidae 1. A-C. Anatoma richardi (Dautzenberg \& H. Fischer, 1896), SEAMOUNT 1, DW116, 985-1000 m, diameter $4.2 \mathrm{~mm}$. D-F. A. richardi, shell and detail of the protoconch and early teleoconch whorls, SEM micrograph, same locality, diameter $1.7 \mathrm{~mm}$. G-I. $A$. cf. richardi, BANGAL 0711, GOC6, $903 \mathrm{~m}$, diameter $2.3 \mathrm{~mm}$. Scale bars: A-D, G-I = $1 \mathrm{~mm} ; \mathrm{E}=200 \mu \mathrm{m} ; \mathrm{F}=100 \mu \mathrm{m}$. 


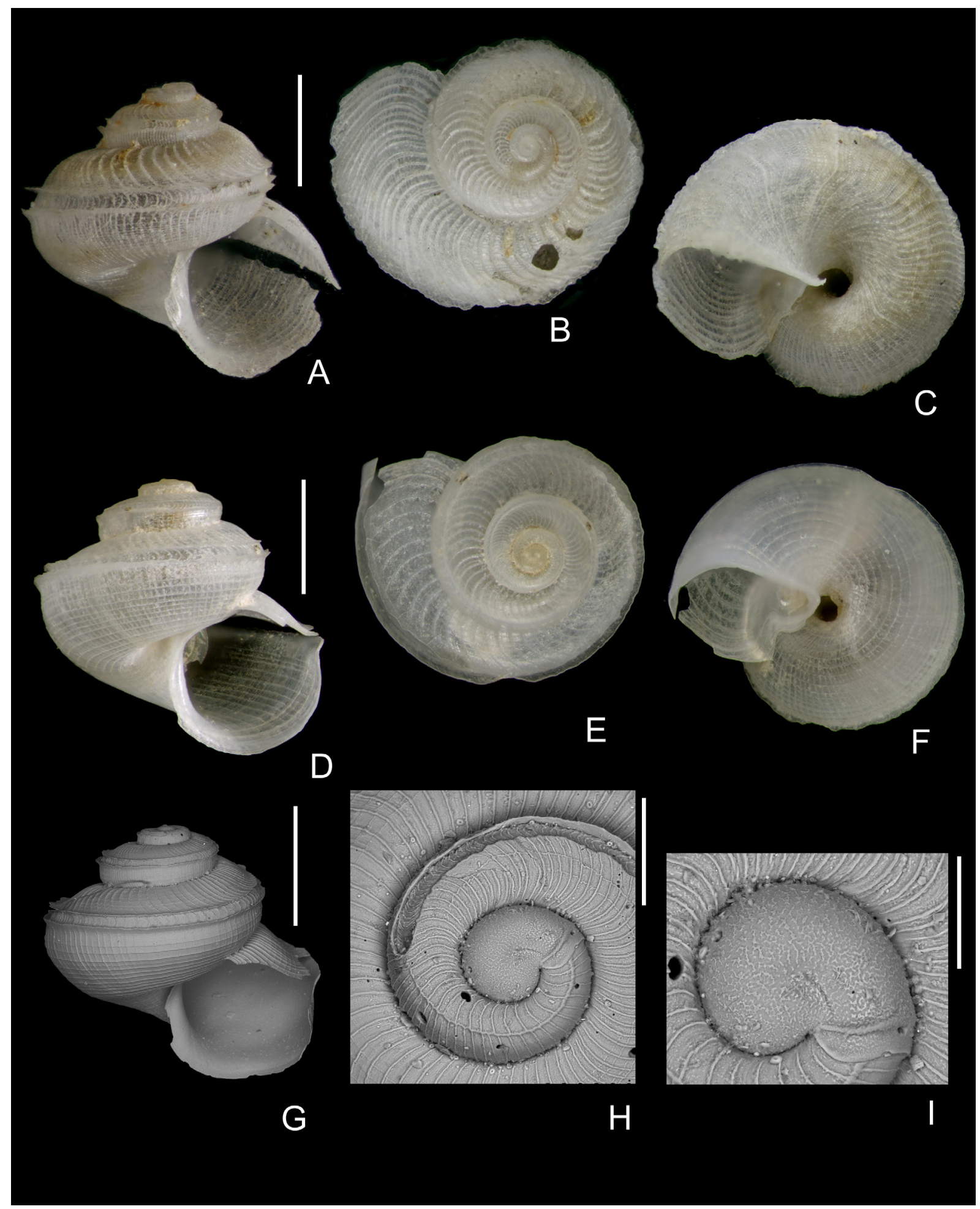

Fig. 8. Anatomidae 2. A-C. Anatoma aspera (Philippi, 1844), SEAMOUNT 1, DW116, 985-1000 m, diameter $2.8 \mathrm{~mm}$. D-F. Anatoma eximia (Seguenza, 1880), SEAMOUNT 1, DW116, 985-1000 m, diameter $2.5 \mathrm{~mm}$. G. A. eximia, SEM micrograph, BANGAL 0711, V4, $744 \mathrm{~m}$, diameter $2.3 \mathrm{~mm}$. H-I. A. eximia, SEM micrograph, details of protoconch and early teleoconch whorls of another shell, same locality. Scale bars: $A-G=1 \mathrm{~mm} ; H=200 \mu \mathrm{m} ; \mathrm{I}=100 \mu \mathrm{m}$. 


\section{Material examined}

GALICIA BANK • $1 \mathrm{spm}, 32 \mathrm{sh} ; 42^{\circ} 52^{\prime} \mathrm{N}, 1^{\circ} 51^{\prime} \mathrm{W}$; 985-1000 m; 20 Oct. 1987; SEAMOUNT 1

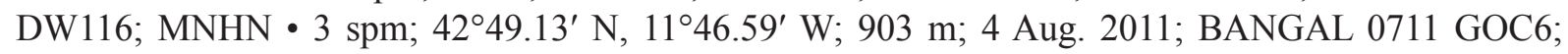
MNCN.

\section{Remarks}

Ortega \& Gofas (2019) used this name for the Anatoma species which is common at depths less than 1000 meters in the Canary Islands, and concluded that the synonymy with Scissurella tenuis Jeffreys, 1877 proposed by Geiger (2012) was not warranted. The latter, with an abyssal type locality in the northwest Atlantic, differs by the configuration of the early whorls and the habitat. Anatoma richardi, originally described from off the Azores Islands in $1360 \mathrm{~m}$, is also found on GB. In A. richardi, the suture of the body whorl may be more or less detached from the selenizone of the previous whorl (the "sutsel" in Geiger 2012), whereas in A. tenuis the suture is reported as always adjusted to it. Anatoma tenuisculpta (Seguenza, 1880), described from the Pleistocene of southern Italy and recorded as living in the Alboran Sea and Ibero-Moroccan Gulf and in several localities off NW Europe (Høisaeter \& Geiger 2011; Geiger 2012), also belongs to this species group but is distinguished by having a higher profile with the last whorl even more clearly separated from the selenizone. We have never seen any

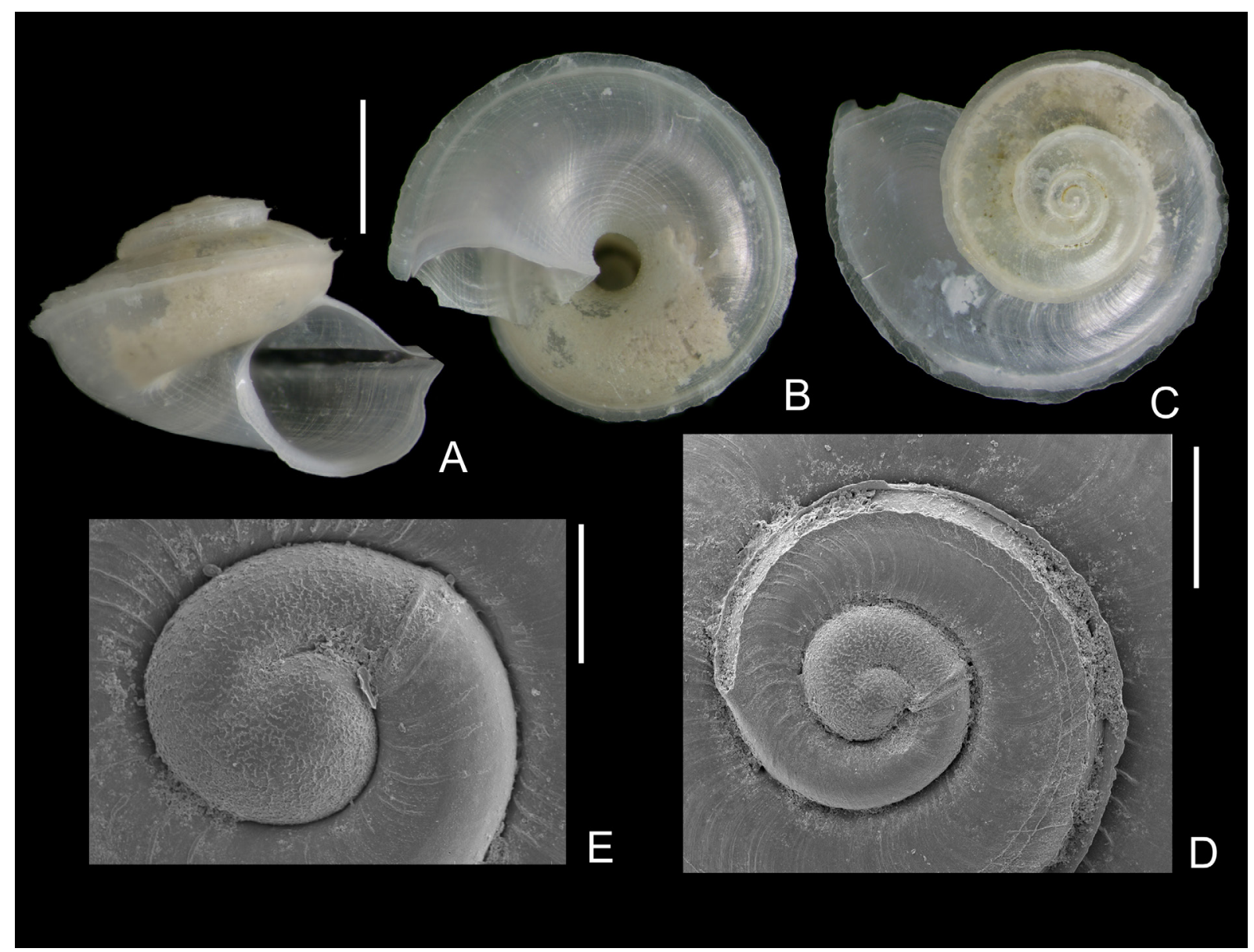

Fig. 9. Anatomidae 3. A-C. Anatoma umbilicata (Jeffreys, 1883), BANGAL 0711, V10, $1720 \mathrm{~m}$, diameter $3.1 \mathrm{~mm}$. D-E. Details of protoconch and early teleoconch whorls of another shell, same locality. Scale bars: A-C $=1 \mathrm{~mm} ; \mathrm{D}=200 \mu \mathrm{m} ; \mathrm{E}=100 \mu \mathrm{m}$. 
locality with $A$. richardi and $A$. tenuisculpta sympatric and separable, and the possibility that they represent morphological variation in a single species should be investigated. Some specimens from GB (Fig. 7G-I), here reported as $A$. cf. richardi, are rather stunted with a rather wide sutsel, but could not be convincingly delimited from typical $A$. richardi.

Anatoma corralae Gofas \& Luque sp. nov.

urn:1sid:zoobank.org:act:990DA613-088E-477A-97C1-45B6207C044B

Fig. 10

\section{Etymology}

The specific name honours Eva Corral Prado, in recognition of her valuable contribution to malacology of this area.

\section{Type material}

Holotype

GALICIA BANK $11 \mathrm{sh}$ (Fig. 10D-F, $4.0 \mathrm{~mm}$ in diameter); $42^{\circ} 41.87^{\prime} \mathrm{N}, 11^{\circ} 26.71^{\prime} \mathrm{W} ; 1720 \mathrm{~m} ; 8$ Aug. 2011; BANGAL 0711 V10; MNCN 15.05/200138H.

\section{Paratypes}

GALICIA BANK • $12 \mathrm{spm}$ and $19 \mathrm{sh}$; same collection data as for holotype; MNCN 15.05/200138P.

\section{Other material examined}

GALICIA BANK • $6 \mathrm{spm}, 14 \mathrm{sh} ; 43^{\circ} 00.12^{\prime} \mathrm{N}, 11^{\circ} 57.67^{\prime} \mathrm{W}$; $1706 \mathrm{~m}$; 29 Jul. 2011; BANGAL $0711 \mathrm{~V} 2$; $\mathrm{MNCN} \bullet 3 \mathrm{sh} ; 42^{\circ} 56.77^{\prime} \mathrm{N}, 11^{\circ} 58.53^{\prime} \mathrm{W}$; $1631 \mathrm{~m}$; 2 Aug. 2011; BANGAL $0711 \mathrm{~V} 5$; MNCN.

\section{Description}

Shell up to $3.3 \mathrm{~mm}$ high and $4.1 \mathrm{~mm}$ maximum diameter, with low conical spire, angulate periphery, moderately inflated base and a small umbilicus. Protoconch of $3 / 4$ whorl, about $240 \mu \mathrm{m}$ in maximum diameter, terminated by a slightly flaring edge; protoconch sculpture of irregular granules which tend to form spiral lines towards the periphery. Teleoconch I (until the beginning of the selenizone) about 1.1 whorl, with about 45-50 faint axial riblets, more indistinct in their adapical part, and with a distinct spiral thread abutting on the beginning of the selenizone. Teleoconch II with 2 to 2.5 whorls, separated by a deep suture, and the space between suture and selenizone (the "sutsel" according to Geiger 2012) somewhat wider than the latter. Marked peripheral keel, accentuated by the abapical edge of selenizone, which is more prominent than the adapical edge. Selenizone delimited by two narrow lamellae, inside with weakly marked growth stages. Adapical surface of whorls with axial riblets and very thin spiral threads; the riblets arched, much narrower than the interspaces, uneven and very irregularly spaced, attenuated upon reaching the selenizone, about 70 on the first whorl of teleoconch II, about 110-120 on the last whorl; spiral threads, about 20 in the last half-whorl, attenuated in the part that borders the selenizone. Base regularly convex, with sculpture of axial riblets and spiral threads similar in density and appearance to those of the adapical part; the ribs are somewhat flexuous and prolonged inside the umbilicus; the spiral cords, about 35-40, are somewhat weaker towards the periphery. Umbilicus small, without apparent funiculus. Aperture rounded, interrupted by an incision which extends on about $1 / 4$ of the last whorl and narrows at the edge. Colour white.

\section{Distribution}

So far only known from deep-water off the GB. 


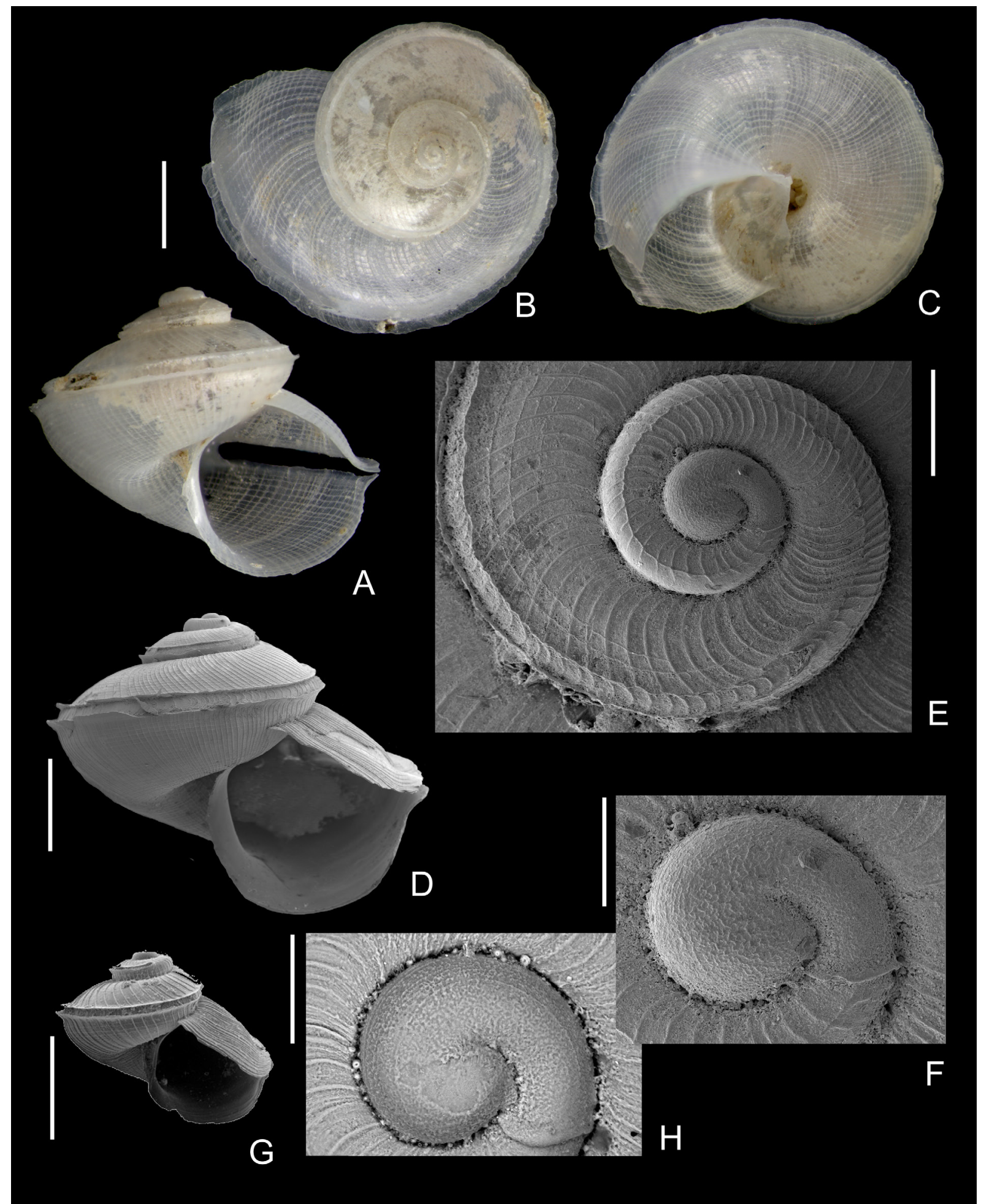

Fig. 10. Anatomidae 4. Anatoma corralae Gofas \& Luque sp. nov. A-C. Paratype (MNCN 15.05/200138P), BANGAL 0711, V10, $1720 \mathrm{~m}, 4.0 \mathrm{~mm}$ diameter. D-F. Holotype (MNCN 15.05/200138H), SEM micrograph, BANGAL 0711, V10, $4.1 \mathrm{~mm}$ diameter. E-F. Details of early teleoconch whorls and protoconch of the holotype. $\mathbf{G}-\mathbf{H}$. Shell and detail of the protoconch, SEM micrographs, from BANGAL 0711, V5, $1631 \mathrm{~m}, 2.1 \mathrm{~mm}$ diameter. Scale bars: A-D, G = $1 \mathrm{~mm}$; E = $200 \mu \mathrm{m} ; \mathrm{F}, \mathrm{H}=100 \mu \mathrm{m}$. 


\section{Remarks}

Anatoma corralae sp. nov. is most similar to A. schiottei Høisaeter \& Geiger, 2011, described from the Norwegian Sea, and was mistaken for it in the preliminary report of INDEMARES BANGAL (Gofas et al. 2014b). It differs in being larger (4 mm, compared to $2.25 \mathrm{~mm}$ in A. schiottei), having a longer teleoconch I (more than one whorl vs 0.75 whorl) with much more numerous axial riblets (50 vs 15), and in lacking a funiculus in the umbilicus (conspicuous in A. schiottei, see Høisaeter \& Geiger 2011: fig. 48). Nevertheless, both species share the same angular outline, the microsculpture of the protoconch with granules tending to be aligned along spiral lines, and the shape of the edge of the protoconch, which is only slightly flaring and has no secondary thickening. The protoconch microsculpture, unusual in the genus, suggests that they may be related.

Among the species locally present, Anatoma umbilicata, which is found together in the same hauls, differs clearly by its broad umbilicus and in being practically smooth. Anatoma tenuisculpta is quite similar to Anatoma corralae sp. nov. in size and outline, but differs in having a much coarser axial sculpture forming a regular lattice with small nodules at the intersections of riblets and spiral threads; it also has a much shorter teleoconch I, hardly over half a whorl. Anatoma richardi, which is found on GB but not in the same depth interval, also has such coarser sculpture, and its last whorl is more ample and its suture is not so far below the selenizone.

\section{"Skeneimorph" species}

This informal group includes the members of the family Skeneidae W. Clark, 1851 but also members of other Vetigastropod families including several genera of uncertain phylogenetic affinity (Hoffman et al. 2020c) which have been shown by Kano et al. (2009) to be related to the superfamily Seguenzioidea or to other non-vetigastropod clades, like neomphalids or heterobranchs (Haszprunar et al. 2011, 2016).

\section{Key to the "skeneimorph" species found in the GB}

1. Shell smooth and glossy, with reduced or filled umbilicus 2

- Shell smooth, but not glossy, or sculptured, with definite umbilicus 3

2. Shell nearly as high as broad ..............Cirsonella romettensis (Granata-Grillo, 1877) (Fig. 14A-C)

- Shell definitely broader than high ( $\mathrm{h} / \mathrm{w}$ less than 0.7$)$ Seamountiella azorica (Dautzenberg \& H. Fischer, 1896) (Fig. 14D-F)

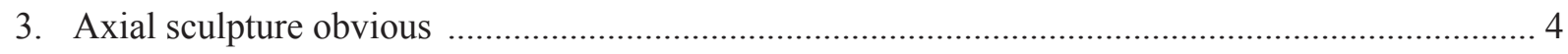

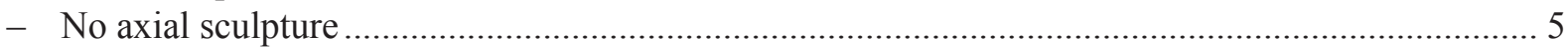

4. Axial sculpture of narrow, widely spaced ribs

Vetulonia paucivaricosa (Dautzenberg, 1889) (Fig. 13F-H)

- Axial sculpture of tightly packed wrinkles "Skenea" ponsonbyi (Dautzenberg \& H. Fischer, 1896) (Fig. 15E-F)

5. Surface, at least around the umbilicus, with a distinct sculpture 6

- No conspicuous sculpture, or only subsutural and/or periumbilical keel ...................................... 13

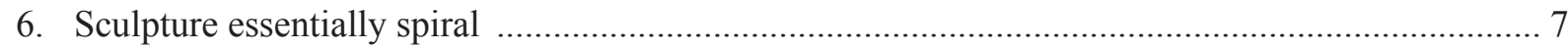

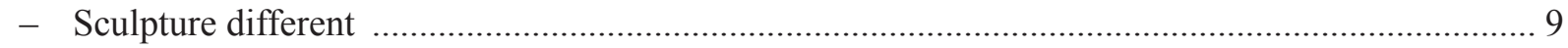

7. Spiral sculpture only surrounding the umbilical area, sometimes a subsutural cord at least on the early whorls Moelleriopsis sp. (Fig. 15C-D)

- Spiral sculpture all over the shell 8 
8. Shell yellowish, sculpture of small but definite spiral ridges

- Shell whitish, sculpture of minute spiral threads

Rugulina fragilis (G.O. Sars, 1878) (Fig. 14G-H)

Anekes spiralis Gofas \& Luque sp. nov. (Fig. 17A-H)

9. Sculpture of oblique threads, which form a mesh

- Sculpture of minute granules all over the shell (may be very tenuous) ........................................... 12

10. Sculpture forming an oblique mesh all over the shell

- Sculpture tenuous, restricted to apical and umbilical areas

Anekes paucistriata Warén, 1992 (Fig. 16F-K)

11. Shell conical, aperture height about half of total height

Anekes affinis (Jeffreys, 1883) (Fig. 16A-E)

- Shell globose, aperture height about two thirds of total height

Granigyra inflata (Warén, 1992) (Fig. 17I-L)

12. Aperture very broad, more than half the shell diameter

- Aperture diameter less than half the shell diameter

Granigyra pruinosa (Jeffreys, 1883) (Fig. 15G-J)

Granigyra tenera (Jeffreys, 1883) (Fig. 15K-L)

13. Spiral keel present at least on the first teleoconch whorl

- Whorls convex, with no spiral keel even around umbilicus

Akritogyra similis (Jeffreys, 1883) (Fig. 15A-B)

14. Abapical keel sharp and distant from the umbilicus ...... Trenchia biangulata Rubio \& Rolán, 2013

- Abapical keel blunt and situated within the umbilicus, or at its edge

15. Shell higher than broad, subsutural keel on most whorls

Mikro scalaroides (Rubio \& Rolán, 2013)

- Shell wider than high, subsutural keel fading on last whorls

Mikro minimus (Seguenza G., 1876) (Fig. 14I-L)

Family uncertain [in superfamily Seguenzioidea Verrill, 1884]

Genus Moelleriopsis Bush, 1897

\section{Type species}

Moelleriopsis abyssicola Bush, 1897, by original designation.

Moelleriopsis sp.

Fig. $15 \mathrm{C}-\mathrm{D}$

\section{Material examined}

GALICIA BANK • 1 sh.; 42 ${ }^{\circ} 51^{\prime} \mathrm{N}, 1^{\circ}{ }^{\circ} 53^{\prime} \mathrm{W}$; 1110-1125 m; 19 Oct. 1987; SEAMOUNT 1 DW108; MNHN.

\section{Remarks}

A single shell from DW108 can be assigned to the genus Moelleriopsis from the broadly umbilicate shell with spiral cords circling the umbilical area. However, the last whorl increases in diameter much more than most of the species possibly present in the area (the Mediterranean Moelleriopsis messanensis (Seguenza, 1876); M. richardi (Dautzenberg \& H. Fischer, 1896) and M. normani (Dautzenberg \& 


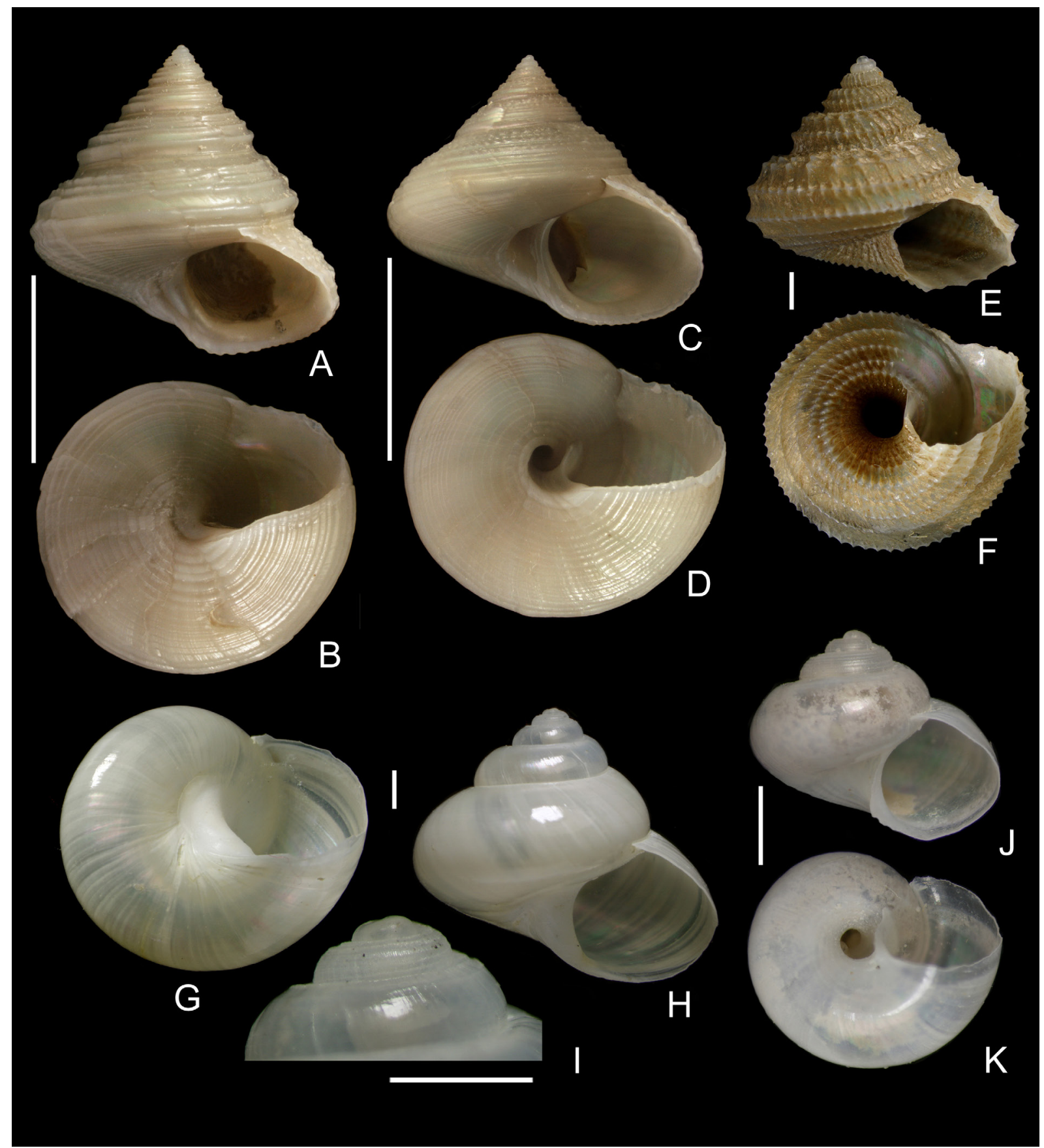

Fig. 11. Trochoidean families. A-B. Calliostoma leptophyma Dautzenberg \& H. Fischer, 1896, ECOMARG 0709, V5, 876 m, 16.5 mm. C-D. Calliostoma maurolici (Seguenza, 1876), ECOMARG 0709, V5, 876 m, 15.6 mm. E-F. Calliotropis vaillanti (P. Fischer, 1882), BANGAL 0711, V9, $1671 \mathrm{~m}$, $7.2 \mathrm{~mm}$. G-I. Bathymophila micans (Dautzenberg \& H. Fischer, 1896), BANGAL 0711, V8, $1565 \mathrm{~m}$, $8 \mathrm{~mm}$. J-K. B. micans, juvenile shell with open umbilicus, BANGAL 0711, V2, $1706 \mathrm{~m}, 3.2 \mathrm{~mm}$. Scale bars: $\mathrm{A}-\mathrm{D}=10 \mathrm{~mm}$; $\mathrm{E}-\mathrm{K}=1 \mathrm{~mm}$. 


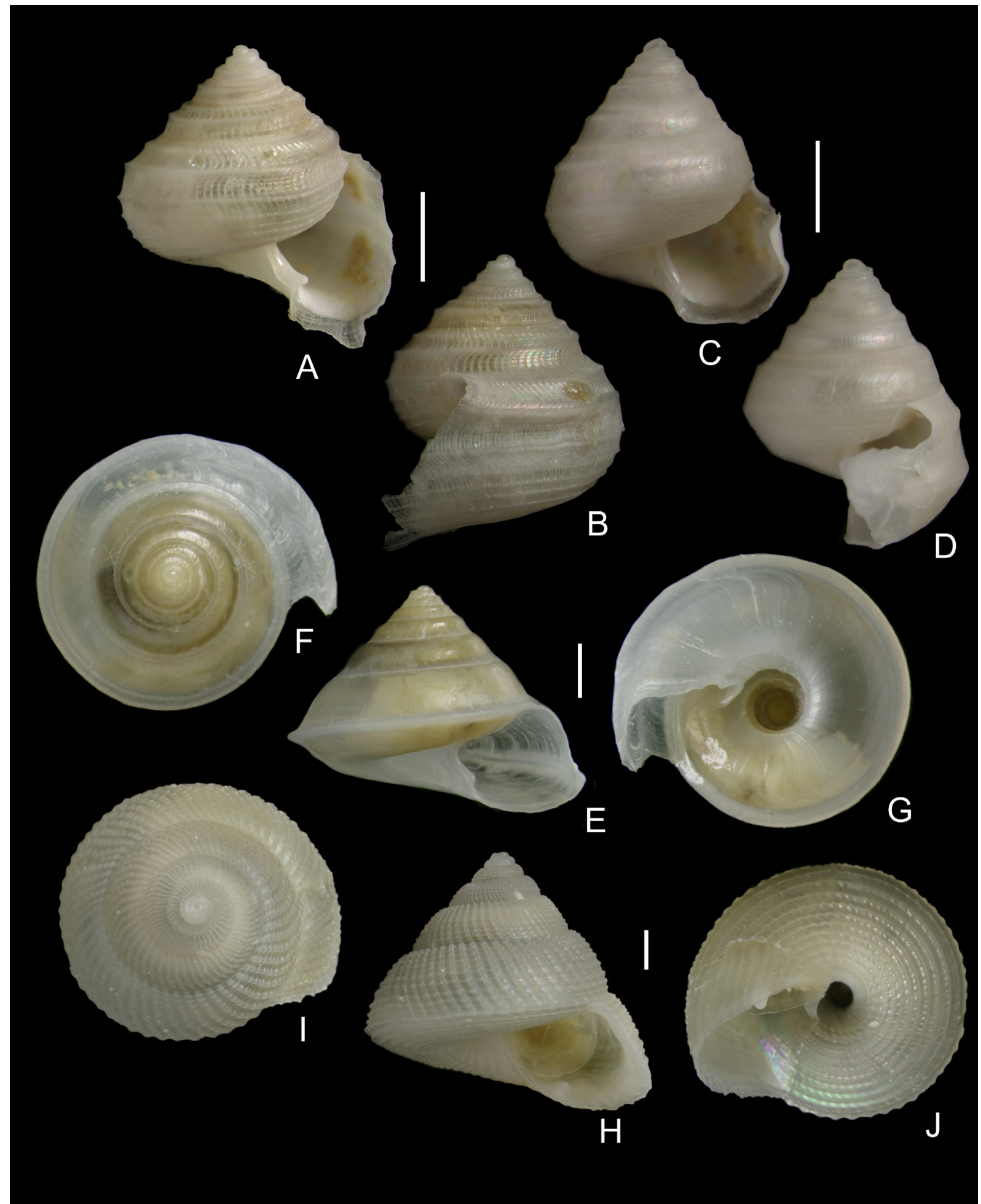

Fig. 12. Seguenziidae. A-B. Seguenzia elegans Jeffreys, 1885, BANGAL 0711, V10, $1720 \mathrm{~m}$, height $3.4 \mathrm{~mm}$. C-D. Seguenzia formosa Jeffreys, 1876, BANGAL 0711, V10, height $3.1 \mathrm{~mm}$. E-G. Carenzia carinata (Jeffreys, 1877), BANGAL 0711, V10, height $4.2 \mathrm{~mm}$. H-J. Ancistrobasis reticulata (Philippi, 1844), BANGAL 0711, V6, $909 \mathrm{~m}$, height $6.5 \mathrm{~mm}$. Scale bars $=1 \mathrm{~mm}$. 


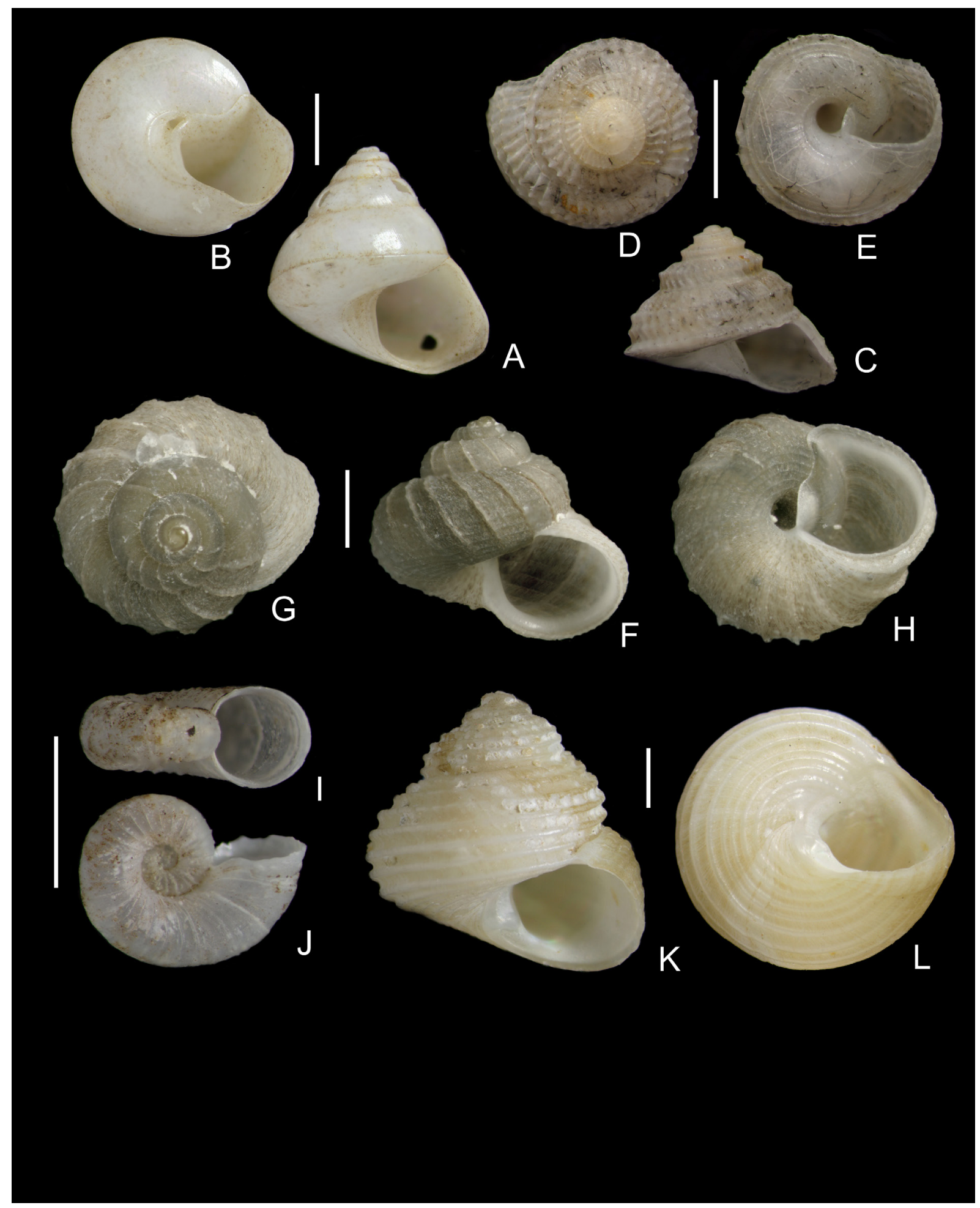

Fig. 13. Seguenzioidea and Colloniidae. A-B. Asthelys munda (Watson, 1879), BANGAL 0711, DR15, 1410 m, 3.2 mm. C-E. Basilissopsis watsoni Dautzenberg \& H. Fischer, 1897, BANGAL 0711, DR12, $1585 \mathrm{~m}, 1.8 \mathrm{~mm}$. F-H. Vetulonia paucivaricosa (Dautzenberg, 1889), BANGAL 0711, V6, $909 \mathrm{~m}$, diameter 3.3 mm. I-J. Adeuomphalus sinuosus (Sykes, 1925), BANGAL 0711, DR12, 1585 m, diameter $1.5 \mathrm{~mm}$. K-L. Cantrainea globuloides (Dautzenberg \& H. Fischer, 1896), SEAMOUNT 1, DW116, 985-1000 m, $4.7 \mathrm{~mm}$. Scale bars $=1 \mathrm{~mm}$. 


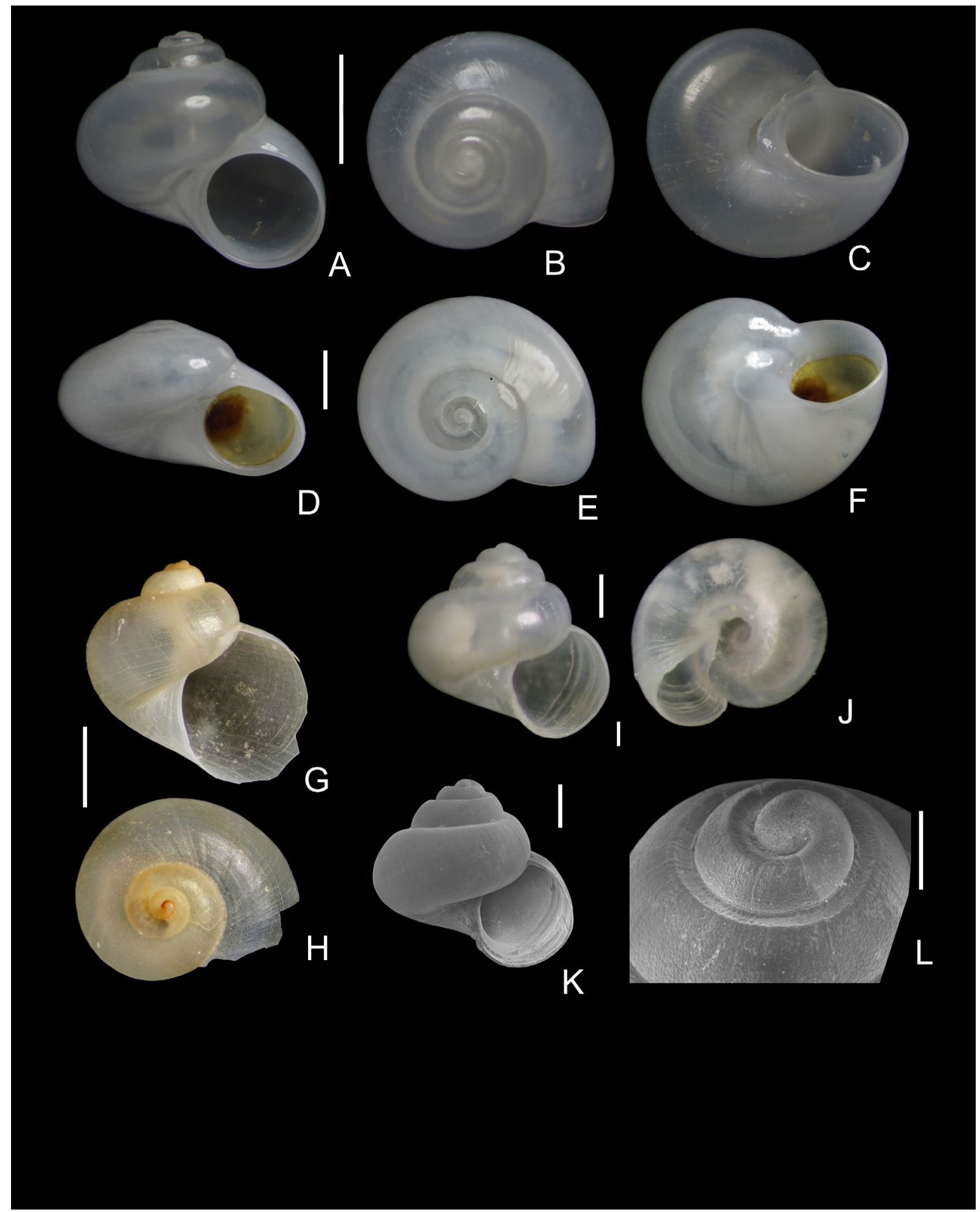

Fig. 14. Skeneimorph species 1. A-C. Cirsonella romettensis (Granata-Grillo, 1877), SEAMOUNT 1, DW116, 985-1000 m, 2.3 mm. D-F. Seamountiella azorica (Dautzenberg \& H. Fischer, 1896), SEAMOUNT 1, DW108, 1120-1125 m, 4.2 mm. G-H. Rugulina fragilis (G.O. Sars, 1878), BANGAL 0711, V2, 1706 m, 2.8 mm. I-J. Mikro minimus (Seguenza, 1876), BANGAL 0711, V5, $1631 \mathrm{~m}$, $0.95 \mathrm{~mm}$. K-L. Mikro minimus, SEM micrograph, same shell, and detail of protoconch and apical whorls. Scale bars: A-K $=1 \mathrm{~mm}: \mathrm{L}=100 \mu \mathrm{m}$. 
H. Fischer, 1897), both described from the Azores; M. atlantis Hoffman, Gofas \& Freiwald, 2020 and M. meteorminora Hoffman, Gofas \& Freiwald, 2020, both from South Azorean Seamount Chain). Moelleriopsis gritta Hoffman, 2020 has a similar coiling but has a distinctive subsutural keel whereas this shell has such a keel only poorly expressed on the first part of the first teleoconch whorl. It probably belongs to an undescribed species but more material is needed before naming it.

Genus Skenea Fleming, 1825

\section{Type species}

Helix serpuloides Montagu, 1808, by subsequent designation.

"Skenea" ponsonbyi (Dautzenberg \& H. Fischer, 1896)

Fig. 15E-F

Cyclostrema ponsonbyi Dautzenberg \& H. Fischer, 1897: 176, pl. 4 figs 12-14.

Skenea ponsonbyi - Hoffman et al. 2020c: 71-73.

\section{Material examined}

GALICIA BANK • $4 \mathrm{sh} ; 4^{\circ} 00.12^{\prime} \mathrm{N}, 1^{\circ} 57.67^{\prime} \mathrm{W}$; $1706 \mathrm{~m}$; 29 Jul. 2011; BANGAL $0711 \mathrm{~V} 2$; MNCN • $5 \mathrm{sh} ; 42^{\circ} 56.77^{\prime} \mathrm{N}, 11^{\circ} 58.53^{\prime} \mathrm{W}$; $1631 \mathrm{~m}$; 2 Aug. 2011; BANGAL $0711 \mathrm{~V} 5$; MNCN • $2 \mathrm{sh} ; 42^{\circ} 59.61^{\prime} \mathrm{N}$, 1158.41' W; 1671 m; 7 Aug. 2011; BANGAL 0711 V9; MNCN.

\section{Remarks}

This is, to our knowledge, the first time that this species is reported outside the Azores (Dautzenberg \& Fischer 1896) and the South Azorean Seamount Chain (Hoffman et al. 2020c). The external sculpture recalls that of Moelleria costulata (Møller, 1842), a boreal Atlantic species which belongs to the family Colloniidae Cossmann, 1917 and has a calcareous operculum fitting exactly the aperture; the flexuous contour of the aperture in the present species suggests that the operculum was flexible and that this similarity does not indicate reationship. For the time being, with no data on the living animal, there is no straightforward generic placement. Cyclostrema Marryat, 1819, a member of the family Liotiidae Gray, 1850 with also a calcareous operculum, is obviously inadequate and we conservatively use the catchall genus "Skenea", in a broad sense meaning a skeneimorph species, following in that WoRMS Editorial Board (2021).

Genus Anekes Bouchet \& Warén, 1979

\section{Type species}

Anekes undulisculpta Bouchet \& Warén, 1979, by original designation.

Anekes spiralis Gofas \& Luque sp. nov. urn:1sid:zoobank.org:act:CBA7FA0B-5656-47A2-ADE8-DEFE58E98B81

Fig. $17 \mathrm{~A}-\mathrm{H}$

\section{Etymology}

The specific name refers to the characteristic spiral sculpture.

\section{Type material}

\section{Holotype}

GALICIA BANK $11 \mathrm{sh}$ (Fig. 17A-G, $1.7 \mathrm{~mm}$ in diameter); $42^{\circ} 56.77^{\prime} \mathrm{N}, 1^{\circ} 58.53^{\prime} \mathrm{W} ; 1631 \mathrm{~m} ; 2$ Aug. 2011; BANGAL 0711 V5; MNCN 15.05/200139H. 


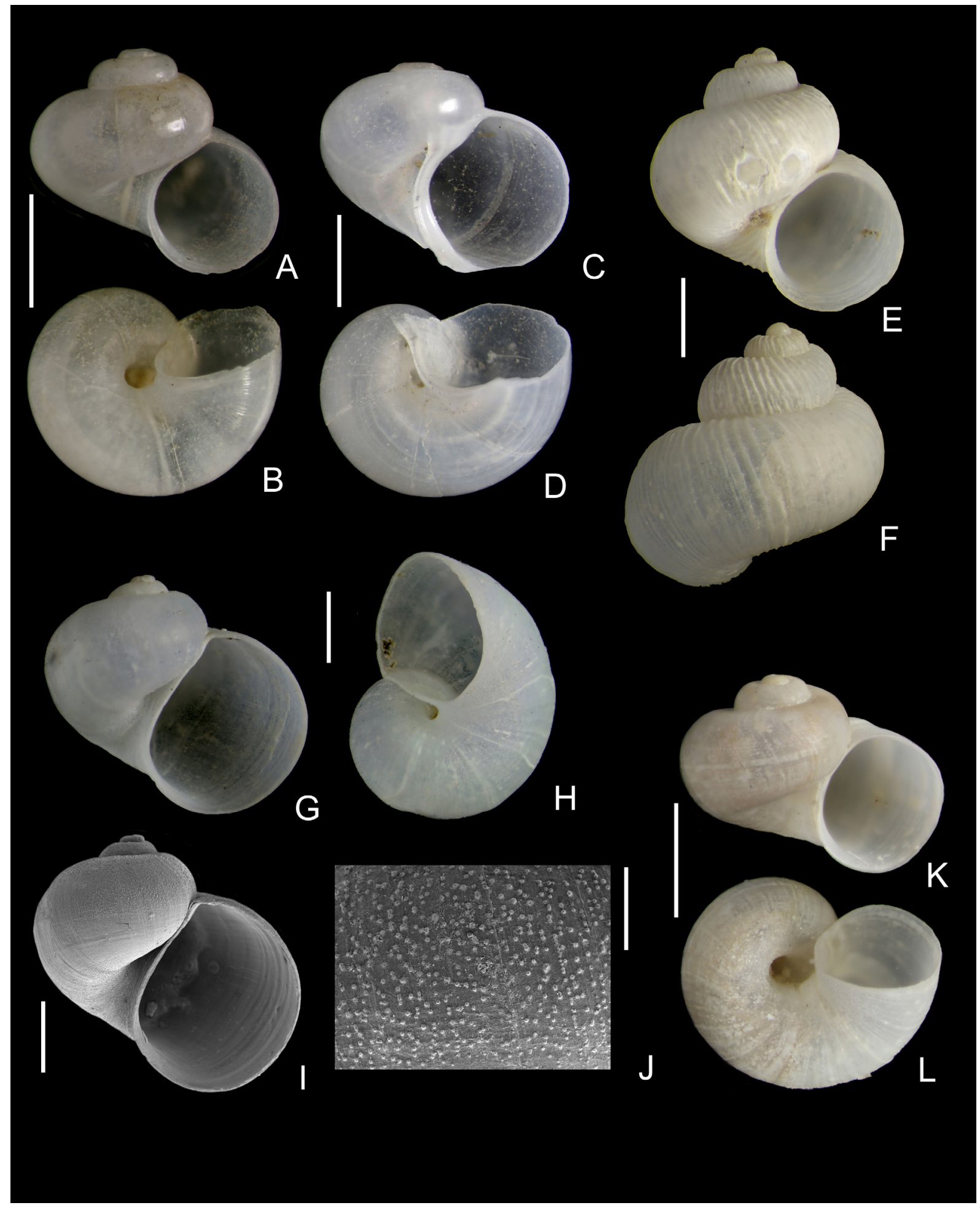

Fig. 15. Skeneimorph species 2. A-B. Akritogyra similis (Jeffreys, 1883), BANGAL 0711, V5, $1631 \mathrm{~m}$, diameter $2.2 \mathrm{~mm}$. C-D. Moelleriopsis sp., SEAMOUNT 1, DW108, 1120-1125 m, $2.7 \mathrm{~mm}$. E-F. "Skenea" ponsonbyi (Dautzenberg \& H. Fischer, 1896), BANGAL 0711, V9, $1671 \mathrm{~m}, 3.2 \mathrm{~mm}$. G-H. Granigyra pruinosa (Jeffreys, 1883), BANGAL 0711, V10, 1720 m, 3.7 mm. I-J. SEM micrograph, same shell, and detail of microsculpture. K-L. Granigyra tenera (Jeffreys, 1883), BANGAL 0711, V10, $1720 \mathrm{~m}, 2.3 \mathrm{~mm}$. Scale bars: A-I, K-L = $1 \mathrm{~mm} ; \mathrm{J}=200 \mu \mathrm{m}$. 


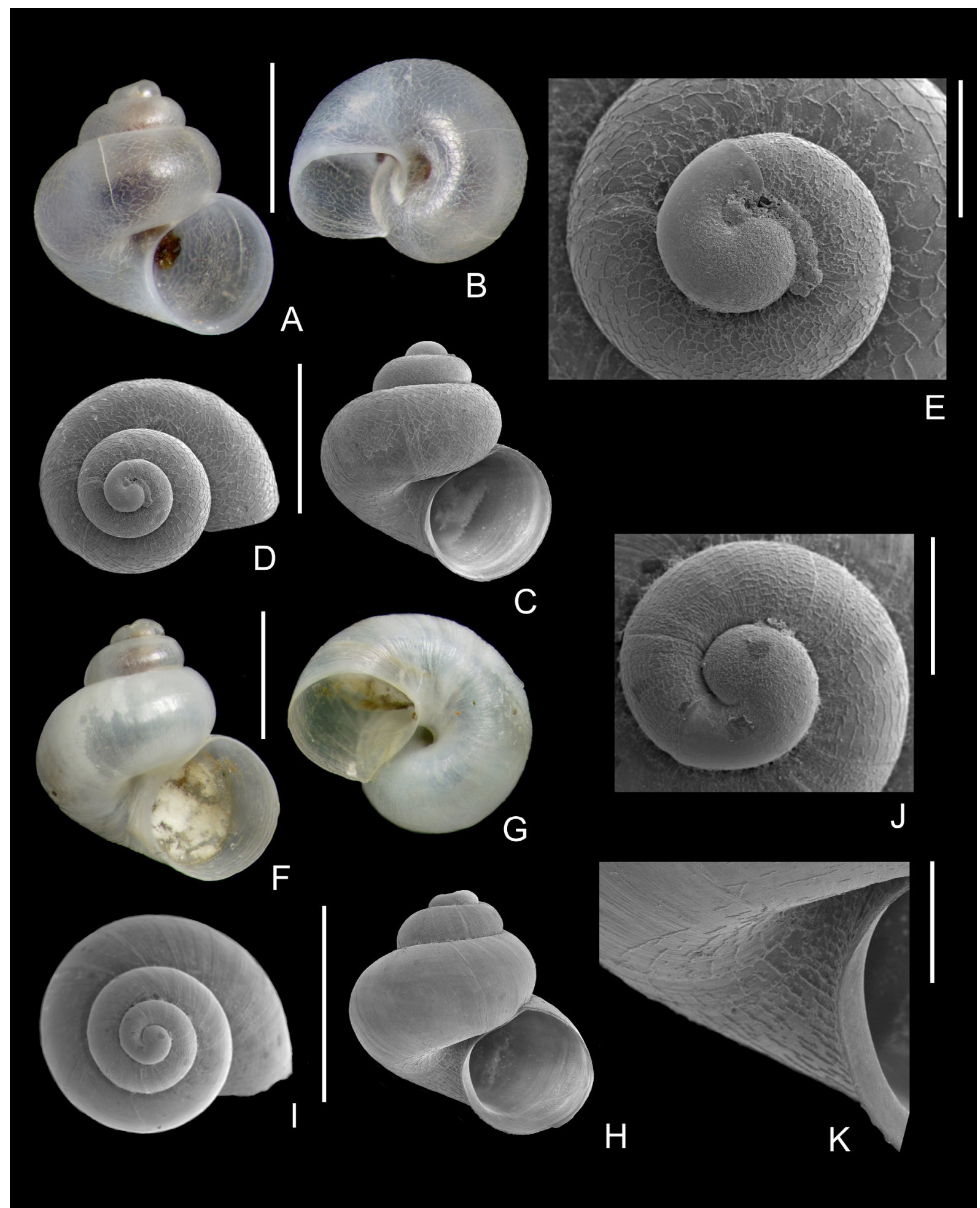

Fig. 16. Skeneimorph species 3. A-B. Anekes affinis (Jeffreys, 1883), BANGAL 0711, V5, $1631 \mathrm{~m}$, diameter $1.4 \mathrm{~mm}$. C-E. SEM micrograph, same specimen, and detail of protoconch and apical whorls, showing the characteristic "Anekes sculpture". F-G. Anekes paucistriata Warén, 1992, BANGAL 0711, V5, $1631 \mathrm{~m}$, live taken specimen, diameter $1.9 \mathrm{~mm}$. H-K. SEM micrograph of another shell, detail of protoconch and apical whorls, and detail of the umbilical area. Scale bars: A-D, F-I $=1 \mathrm{~mm}$; $\mathrm{E}, \mathrm{J}-\mathrm{K}=200 \mu \mathrm{m}$. 


\section{Paratypes}

GALICIA BANK • $1 \mathrm{spm}$ and $7 \mathrm{sh}$; same collection data as for holotype; MNCN 15.05/200139P.

\section{Other material examined}

GALICIA BANK • $1 \mathrm{sh} ; 43^{\circ} 00.12^{\prime} \mathrm{N}, 11^{\circ} 57.67^{\prime} \mathrm{W} ; 1706 \mathrm{~m}$; 29 Jul. 2011; BANGAL $0711 \mathrm{~V} 2$; MNCN.

\section{Description}

Shell minute, very fragile and translucent, up to $2.1 \mathrm{~mm}$ height and maximum diameter, trochiform, with a moderately low, slightly cyrtoconoid spire, a rounded periphery and body whorl, and a small but definite umbilicus. Protoconch of $3 / 4$ whorl, about $260 \mu \mathrm{m}$ in maximum diameter, terminated by a simple, curved edge; protoconch sculpture of minute, irregularly spaced granules. Teleoconch with up to 3 convex whorls. First whorls sculptured by minute spiral threads, irregular in size and spacing, about half the size of interspaces; occasionally these threads are interrupted or anastomosing. The spiral threads become inconspicuous on the later whorls, persisting in the subsutural zone and within the umbilical area, but lacking in the median part of the body whorl, where only growth lines can be seen. Umbilicus narrow and deep, not delimited from the rest the whorl. Aperture evenly rounded except for a slight angle at the termination of the suture; outer lip very thin, slightly flexuous, slightly prosocline. Colour slightly yellowish on fresh shells, otherwise whitish.

\section{Remarks}

Species of Anekes are mostly characterized by a peculiar "Anekes sculpture" which consists of minute raised lines, anastomosing in a criss-cross pattern. In Anekes affinis (Jeffreys, 1883) this sculpture is spread over the entire surface and quite noticeable. Anekes sculpturata Warén, 1992 is similar but smaller (hardly exceeds $1 \mathrm{~mm}$ ) and the microsculpture has a preferential orientation in the spiral direction, while in A. affinis it forms a non-directional network. In Anekes paucistriata Warén, 1992 the sculpture is evident only on the first whorl and may also occur in the umbilicus, but it is almost completely missing in intermediate surface and an attentive examination is required, under strong magnification and preferably under SEM, to detect it. This kind of sculpture is not exclusive of the genus Anekes, and it is also present on Granigyra inflata (Warén, 1992), originally described in Anekes but later (Warén 1996) found to have radular characters closer to Granigyra Dall, 1889.

Anekes spiralis sp. nov. differs from the other species of Anekes in that the microsculpture is definitely spiral, not just with a preferential orientation like in A. sculpturata or in A. undulisculpta, but a limited anastomosing pattern occurs on some (especially the very early) parts of the shell of A. spiralis sp. nov., supporting the generic placement.

Subclass Caenogastropoda Cox, 1960

Family Eulimidae Philippi, 1853

\section{Key to the species of Eulimidae found in the GB}

Adapted from Bouchet \& Warén (1986), to whom we refer for a detailed account of identification criteria and for descriptive terminology. Caution must be taken as more species are likely to occur on GB, so that the identification through the key should be carefully checked against the illustrations; Bouchet \& Warén (1986) should anyway be consulted regarding this group. The supraspecific classification in this group still needs elaboration, and "Eulima" with quotes is used (e.g., Bouchet \& Warén 1986) as a catchall for nondescript species for which a generic assignment is not straightforward.

1. Apex and/or whole shell brownish or yellowish, or with a pattern with such colours ..................... 2

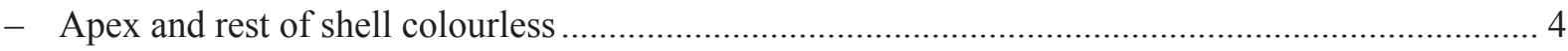


2. Teleoconch with a blurry yellowish band

“Eulima" leptozona Dautzenberg \& H. Fischer, 1896 (Fig. 19H-I)

- Teleoconch colourless or uniformly yellowish

3. Last whorl about half of the total height

- Last whorl about $40 \%$ or less of the total height

Fuscapex cabiochi Bouchet \& Warén, 1986 (Fig. 20C-D)

Batheulima fuscoapicata (Jeffreys, 1884) (Fig. 20A-B)

4. Shell with a thin columella and an umbilical chink, without any scars of growth stages ................ 5

- Shell with thickened columella, imperforate, with scars marking former growth stages (may need careful examination under strong illumination reflected on the glossy surface) ............................... 7

5. Shell rather large (may be $>10 \mathrm{~mm}$ ), with distinct prosocline ribs

Costaclis mizon (Watson, 1881) (Fig. 20O-P)

- Shell small, smooth or with axial growth lines

6. Last whorl nearly half of the total height

.Hemiaclis obtusa Bouchet \& Warén, 1986 (Fig. 20K-L)

- Last whorl hardly more than one-third of total height .....Aclis walleri Jeffreys, 1867 (Fig. 20M-N)

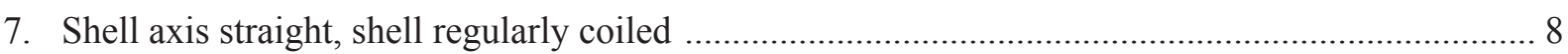

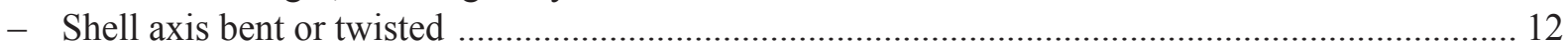

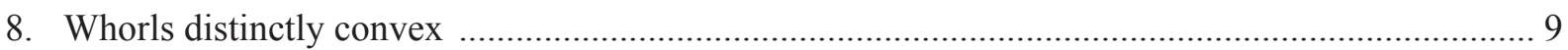

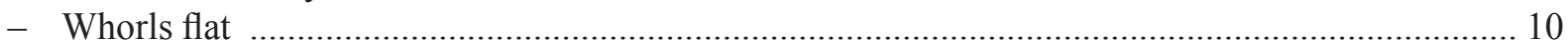

9. Shell tall, last whorl less than half the total height

Melanella cf. myriotrochi Bouchet \& Warén, 1986 (Fig. 19F-G)

- Shell relatively short, last whorl about $60 \%$ of total height

Bathycrinicola talaena (Dautzenberg \& H. Fischer, 1896) (Fig. 20G-H)

10. Larval shell with more than two whorls, apex pointed

“Eulima" anonyma Bouchet \& Warén, 1986 (Fig. 19J-K)

- Larval shell with less than 2 whorls, apex globose

11. Shell about $2 \mathrm{~mm}$, cylindrical, with flaring outer lip

Fusceulima digitalis Hoffman \& Engl, 2021 (Fig. 20I-J)

- Shell reaching more than $2 \mathrm{~mm}$, high-conical, outer lip not flaring Melanella jeffreysi (Tryon, 1886) (Fig. 19D-E)

12. Shell small $(<3 \mathrm{~mm})$ and curved only in one plane, parietal edge continuous with columella

Eulitoma obtusiuscula Bouchet \& Warén, 1986 (Fig. 19L-O)

- Shell large (>5 mm), distorted, parietal edge and columella differentiated

13. Shell very slender $(\mathrm{h} / \mathrm{w}>3.6)$

Campylorhaphion machaeropsis (Dautzenberg \& H. Fischer, 1896) (Fig. 20E-F)

- Shell moderately slender (h/w about 3)

Melanella spiridioni (Dautzenberg \& H. Fischer, 1896) (Fig. 19A-C) 


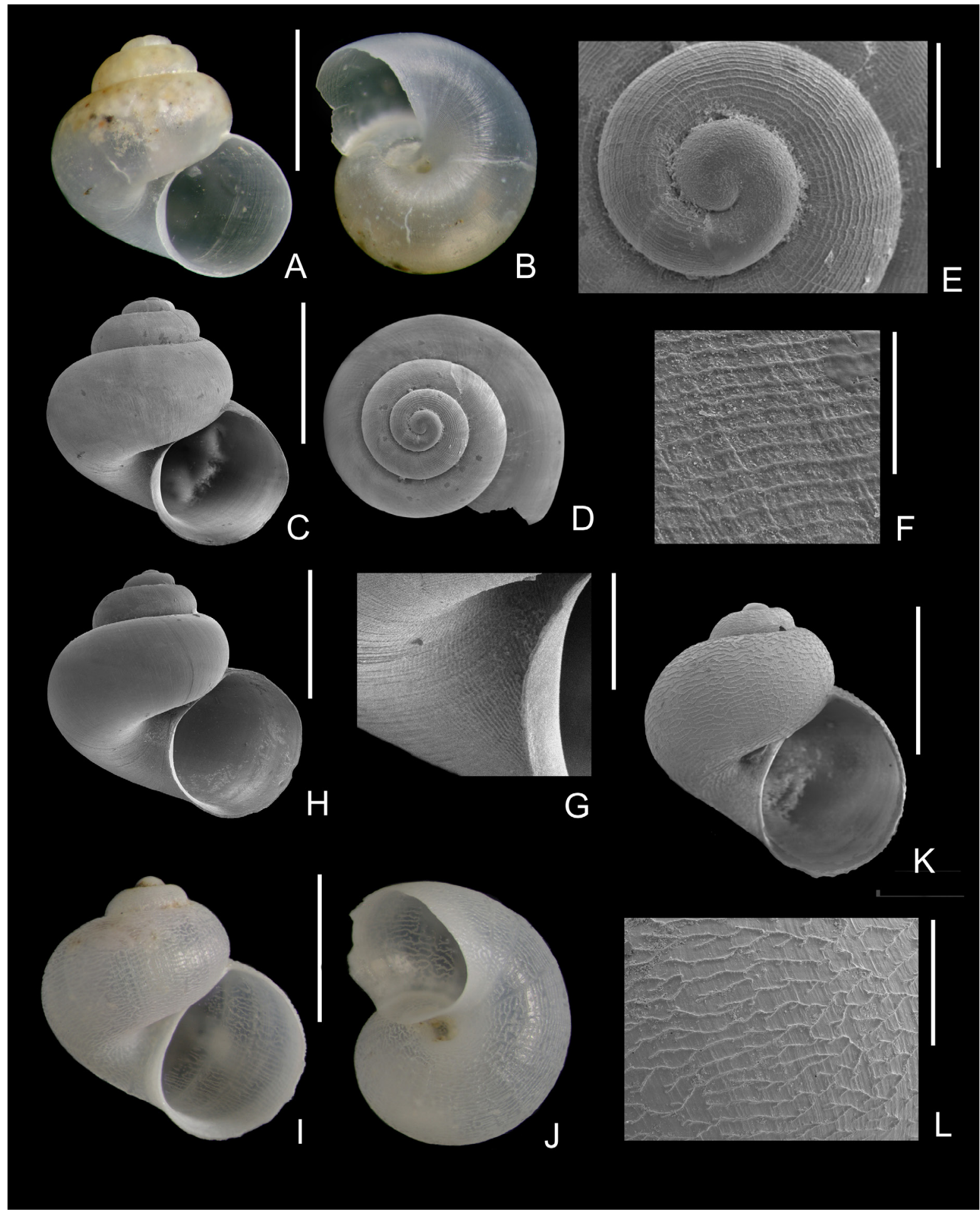

Fig. 17. Skeneimorph species 4. A-H. Anekes spiralis Gofas \& Luque sp. nov. A-B. Holotype (MNCN 15.05/200139H), BANGAL 0711, V5, $1631 \mathrm{~m}$, diameter $1.7 \mathrm{~mm}$. C-D. SEM micrograph of the holotype. E. Apical view, protoconch and early teleoconch whorl of the holotype. F. Detail of the microsculpture of the adapical part of the last whorl. G. Detail of the umbilical area of the holotype. H. Paratype (MNCN 15.05/200139P), SEM micrograph, same locality, $2.0 \mathrm{~mm}$. I-J. Granigyra inflata (Warén, 1992), BANGAL 0711, V5, $1631 \mathrm{~m}$, diameter $1.8 \mathrm{~mm}$. K-L. Same shell, SEM micrograph and detail of the microsculpture of the last whorl. Scale bars: A-D, H-K $=1 \mathrm{~mm} ; \mathrm{E}, \mathrm{G}, \mathrm{L}=200 \mu \mathrm{m} ; \mathrm{F}=50 \mu \mathrm{m}$. 


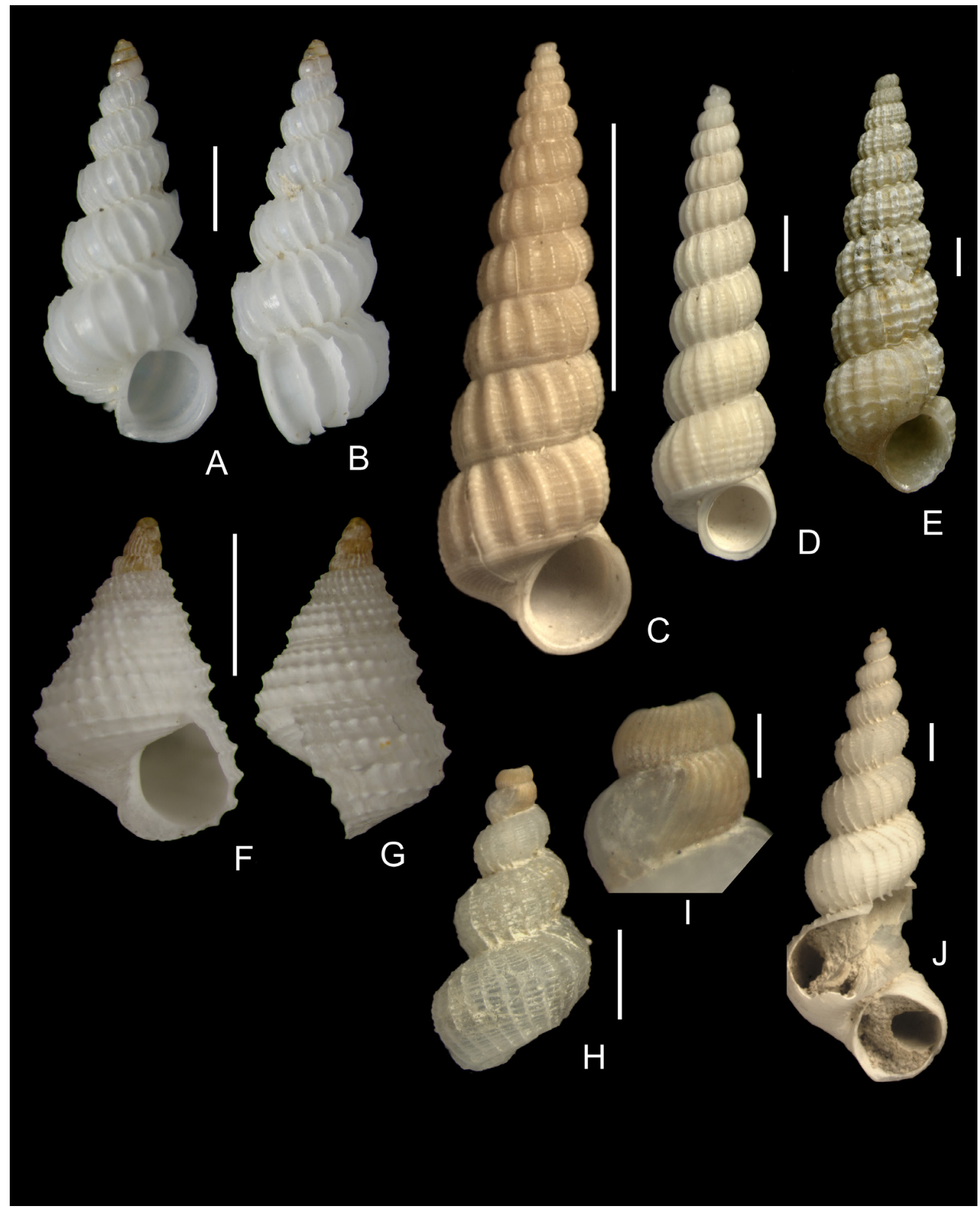

Fig. 18. Epitoniidae. A-B. Epitonium dallianum (Verrill \& S. Smith, 1880), SEAMOUNT 1, DW116, 985-1000 m, 5.0 mm. C. Cylindriscala thalassae Bouchet \& Warén, 1986, BANGAL 0711, DR14, $1130 \mathrm{~m}, 23.5 \mathrm{~mm}$. D. Cylindriscala guernei (Dautzenberg \& de Boury, 1897), BANGAL 0711, DR15, $1410 \mathrm{~m}, 8.5 \mathrm{~mm}$. E. Opaliopsis atlantis (Clench \& R.D. Turner, 1952), SEAMOUNT 1, DW111, 675-685 m, 11.0 mm. F-G. Iphitus tuberatus Jeffreys, 1883, SEAMOUNT 1, DW108, 1120-1125 m, $2.3 \mathrm{~mm}$. H-I. Eccliseogyra folini (Dautzenberg \& de Boury, 1897), shell and detail of protoconch, BANGAL 0711, V2, 1706 m, 3.4 mm. J. E. folini, BANGAL 0711, V10, 1720 m, 12.3 mm. Scale bars: A-B, D-H, J = $1 \mathrm{~mm} ; \mathrm{C}=10 \mathrm{~mm}$; $=200 \mu \mathrm{m}$. 
Genus Melanella Bowdich, 1822

\section{Type species}

Melanella dufresnei Bowdich, 1822, by monotypy.

Melanella cf. myriotrochi Bouchet \& Warén, 1986

Fig. 19F-G

Melanella? myriotrochi Bouchet \& Warén, 1986: 383, figs 906-907.

\section{Material examined}

GALICIA BANK • $1 \mathrm{spm} ; 43^{\circ} 00.12^{\prime} \mathrm{N}, 1^{\circ} 57.67^{\prime} \mathrm{W}$; $1706 \mathrm{~m}$; 29 Jul. 2011; BANGAL $0711 \mathrm{~V} 2$; MNCN

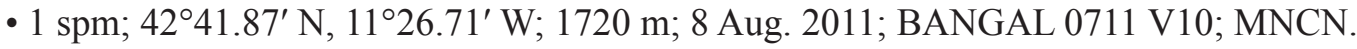

\section{Remarks}

This species was described on a single specimen, probably immature judging from the very thin, brittle aperture. The specimen illustrated here is larger and definitely adult, but has, like the holotype, a small mucronate protoconch, teleoconch whorls unusually convex for a eulimid, and a projecting profile of the outer lip, making this the closest match we could find among the species described from the area. This identification remains tentative, especially taking into account that the host holothurian species was not found in our material.

\section{Genus Fusceulima Laseron, 1955}

\section{Type species}

Fusceulima jacksonensis Laseron, 1955, by original designation.

Fusceulima digitalis Hoffman \& Engl, 2021

Fig. 20I-J

Balcis sp. - Rolán Mosquera 1983: 199.

\section{Material examined}

GALICIA BANK • $1 \mathrm{sh} ; 42^{\circ} 41.94^{\prime} \mathrm{N}, 11^{\circ} 40.58^{\prime} \mathrm{W} ; 744 \mathrm{~m}$; 31 Jul. 2011; BANGAL $0711 \mathrm{~V} 4$; MNCN • $3 \mathrm{sh} ; 4^{\circ} 28.81^{\prime} \mathrm{N}, 11^{\circ} 50.03^{\prime} \mathrm{W}$; $1410 \mathrm{~m}$; 8 Aug. 2011; BANGAL $0711 \mathrm{DR} 15$; MNCN.

\section{Remarks}

This recently described species is very different from any known eulimid in European waters. It is tentatively included in the genus Fusceulima Laseron, 1955, due to its small shell, with few, almost flat whorls, short aperture and curved outer lip (see diagnosis of Fusceulima in Bouchet \& Warén 1986, Souza \& Pimenta 2014 and Engl et al. 2021). It was described and illustrated for the first time as Balcis sp. by Rolán Mosquera (1983: 199), from the Galicia Bank.

Families Buccinidae Rafinesque, 1815 and Colidae Gray, 1857

Key to species of Buccinidae and Colidae found in the GB (see also Bouchet \& Warén 1985)

1. Sculpture conspicuous, with definite spiral ridges 2

- Sculpture attenuated, consisting only of fine spiral grooves 3 


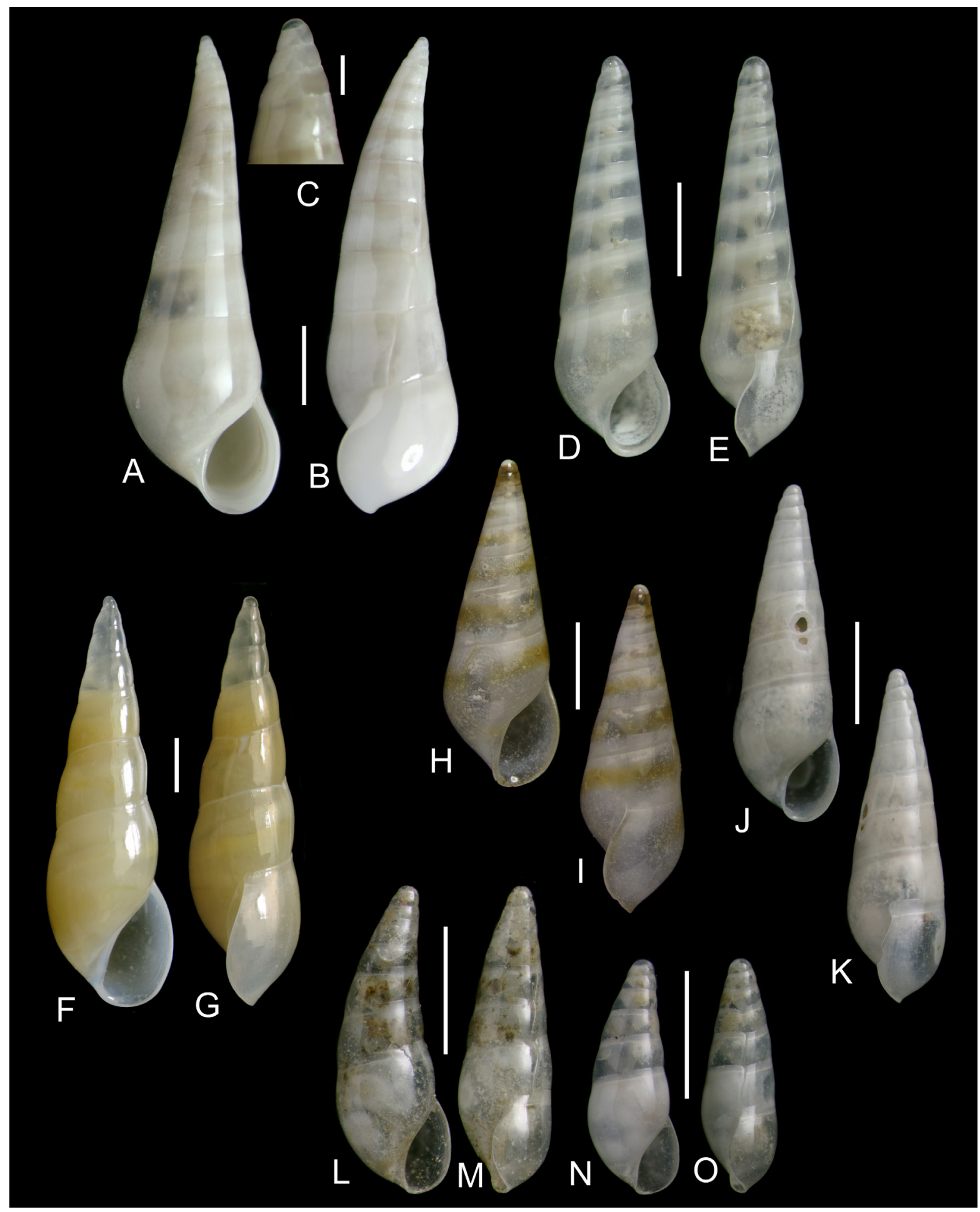

Fig. 19. Eulimidae 1. A-C. Melanella spiridioni (Dautzenberg \& H. Fischer, 1896) and detail of protoconch, BANGAL 0711, V5, $1631 \mathrm{~m}, 6.0 \mathrm{~mm}$. D-E. Melanella jeffreysi (Tryon, 1886), BANGAL 0711, V2, 1706 m, 4.3 mm. F-G. Melanella cf. myriotrochi Bouchet \& Warén, 1986, BANGAL 0711, V2, 7.6 mm. H-I. "Eulima" leptozona Dautzenberg \& H. Fischer, 1896, SEAMOUNT 1, DW111, 675-685 m, 3.8 mm. J-K. "Eulima" anonyma Bouchet \& Warén, 1986, BANGAL 0711, V2, 3.3 mm. L-O. Eulitoma obtusiuscula Bouchet \& Warén, 1986, BANGAL 0711, DR15, $1410 \mathrm{~m}, 2.4$ and $1.85 \mathrm{~mm}$. Scale bar for A-B, D-O = $1 \mathrm{~mm} ; \mathrm{C}=200 \mu \mathrm{m}$. 


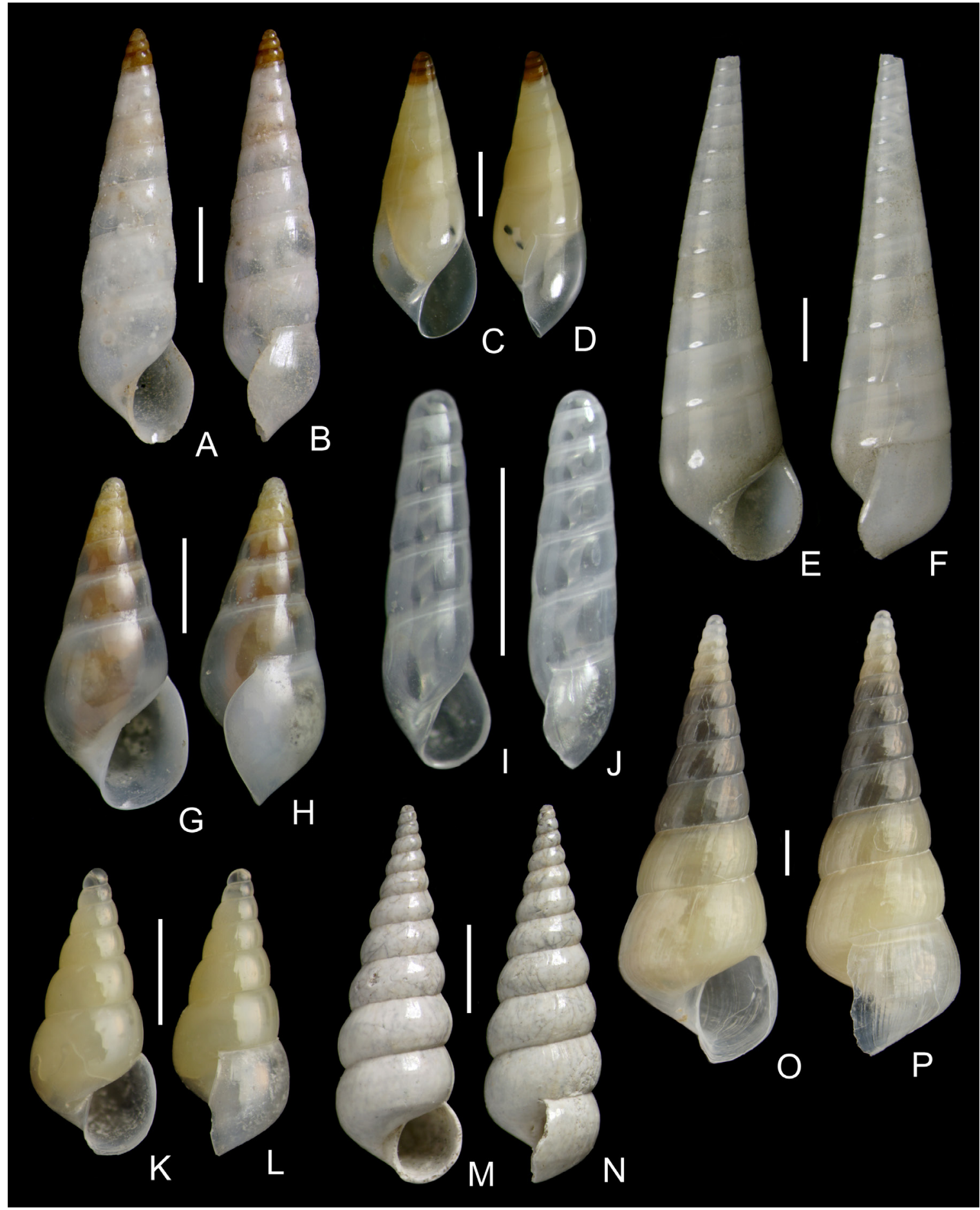

Fig. 20. Eulimidae 2. A-B. Batheulima fuscoapicata (Jeffreys, 1884), BANGAL 0711, DR15, 1410 m, 5.5 mm. C-D. Fuscapex cabiochi Bouchet \& Warén, 1986, BANGAL 0711, DR15, 4.4 mm. E-F. Campyloraphion machaeropsis (Dautzenberg \& H. Fischer, 1896), SEAMOUNT 1, DW108, 1110-1125 m, 8.0 mm. G-H. Bathycrinicola talaena (Dautzenberg \& H. Fischer, 1896), SEAMOUNT 1, DW116, 985-1000 m, 3.5 mm. I-J. Fusceulima digitalis Hoffman \& Engl, 2021, BANGAL 0711, DR15, $2.0 \mathrm{~mm}$. K-L. Hemiaclis obtusa Bouchet \& Warén, 1986, BANGAL 0711, V10, $1720 \mathrm{~m}$, $2.7 \mathrm{~mm}$. M-N. Aclis walleri Jeffreys, 1867, BANGAL 0711, V5, $1631 \mathrm{~m}, 4.3 \mathrm{~mm}$. O-P. Costaclis mizon (Watson, 1881), BANGAL 0711, V10, $9.8 \mathrm{~mm}$. Scale bars $=1 \mathrm{~mm}$. 


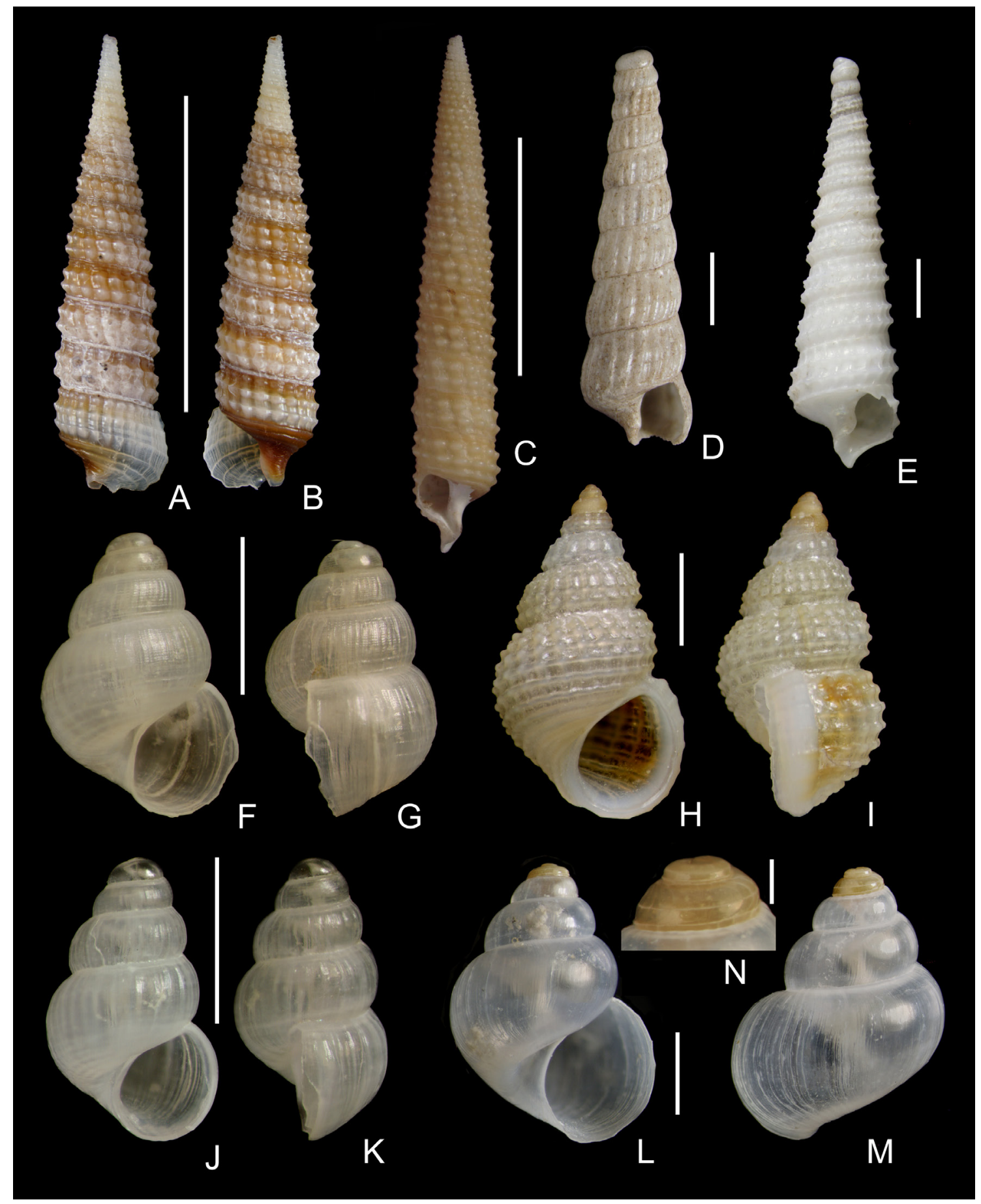

Fig. 21. Triphoridae, Newtoniellidae, Rissoidae. A-B. Strobiligera lubrica (Bouchet \& Warén, 1993), BANGAL 0711, V8, 1565 m, 14.6 mm. C. Strobiligera brychia (Bouchet \& Guillemot, 1978), SEAMOUNT 1, DW116, 985-1000 m, $21.5 \mathrm{~mm}$. D. Eumetula bouvieri (Dautzenberg \& H. Fischer, 1896), BANGAL 0711, DR15, 1410 m, 5.5 mm. E. Cerithiella metula (Lovén, 1846), BANGAL 0711, V10, 1720 m, 7.0 mm. F-G. Alvania porcupinae Gofas \& Warén, 1982, BANGAL 0711, DR15, $1.8 \mathrm{~mm}$. H-I. Alvania cimicoides (Forbes, 1844), SEAMOUNT 1, DW108, 1110-1125 m, 3.6 mm. J-K. Gofasia galiciae Bouchet \& Warén, 1993, BANGAL 0711, DR15, 1.7 mm. L-N. Benthonella tenella (Jeffreys, 1869), BANGAL 0711, V5, $1631 \mathrm{~m}, 3.4 \mathrm{~mm}$, and detail of the protoconch. Scale bars: A-C $=10 \mathrm{~mm}$; $\mathrm{D}-\mathrm{M}=1 \mathrm{~mm} ; \mathrm{N}=200 \mu \mathrm{m}$. 


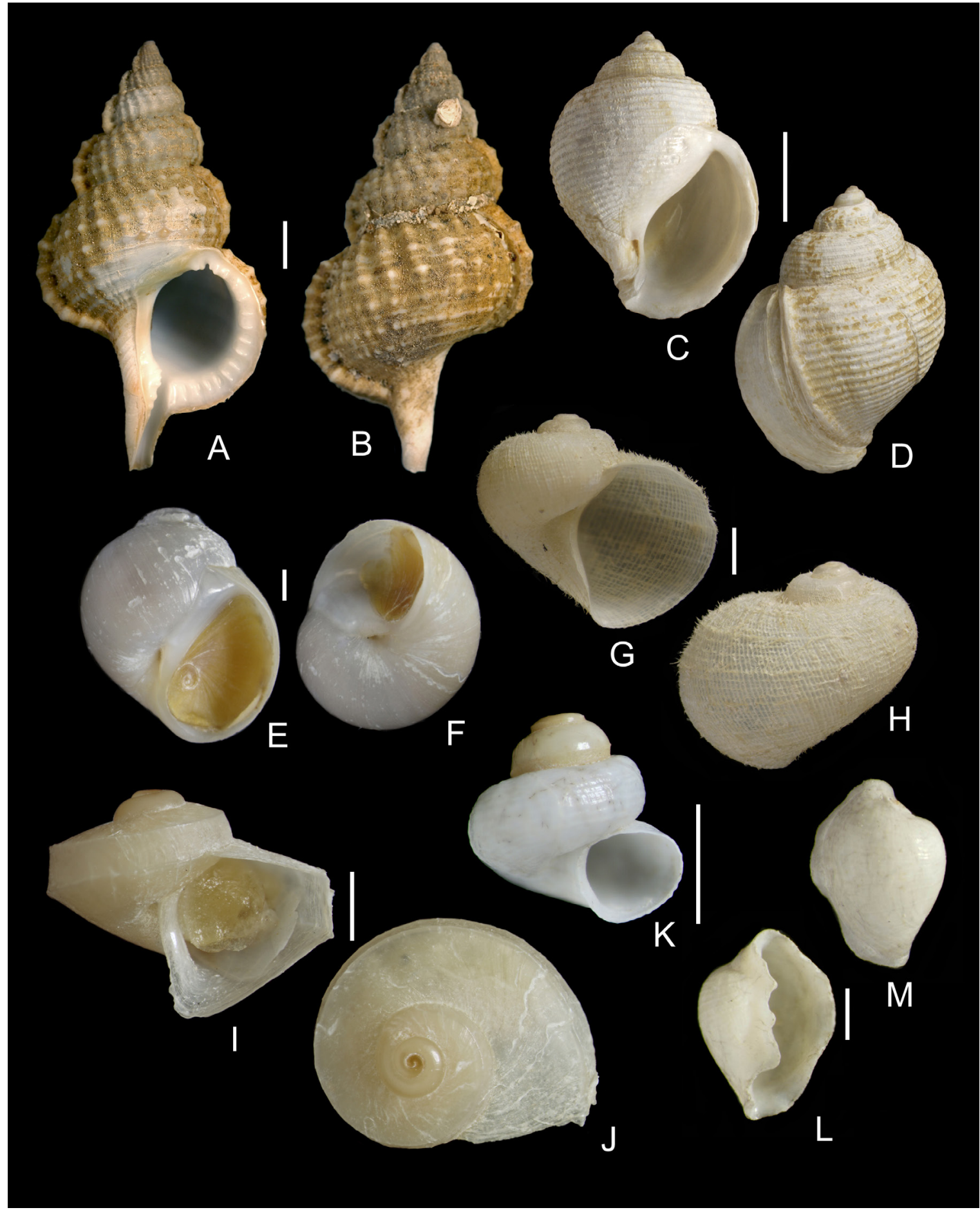

Fig. 22. Ranellidae, Cassidae, Naticidae, Capulidae, Haloceratidae, Ovulidae. A-B. Ranella olearium (Linnaeus, 1758), BANGAL 0711, V6, 909 m, $90 \mathrm{~mm}$. C-D. Oocorys sulcata P. Fischer, 1884, BANGAL 0711, V8, 1565 m, 32 mm. E-F. Euspira subplicata (Jeffreys, 1885), BANGAL 0711, V10, 1720 m, 7.5 mm. G-H. Torellia delicata (Philippi, 1844), BANGAL 0711, V10, $5.2 \mathrm{~mm}$. I-J. Haloceras cingulatum (Verrill, 1884), live-collected specimen, BANGAL 0711, V10, diameter $4.1 \mathrm{~mm}$. K. Haloceras carinatum (Jeffreys, 1883), SEAMOUNT 1, DW116, 985-1000 m, diameter $1.8 \mathrm{~mm}$. L-M. Pedicularia sicula Swainson, 1840, SEAMOUNT 1, DW108, 1110-1125 m, $3.7 \mathrm{~mm}$. Scale bars: A-D = $10 \mathrm{~mm}$; $-\mathrm{M}=1 \mathrm{~mm}$. 


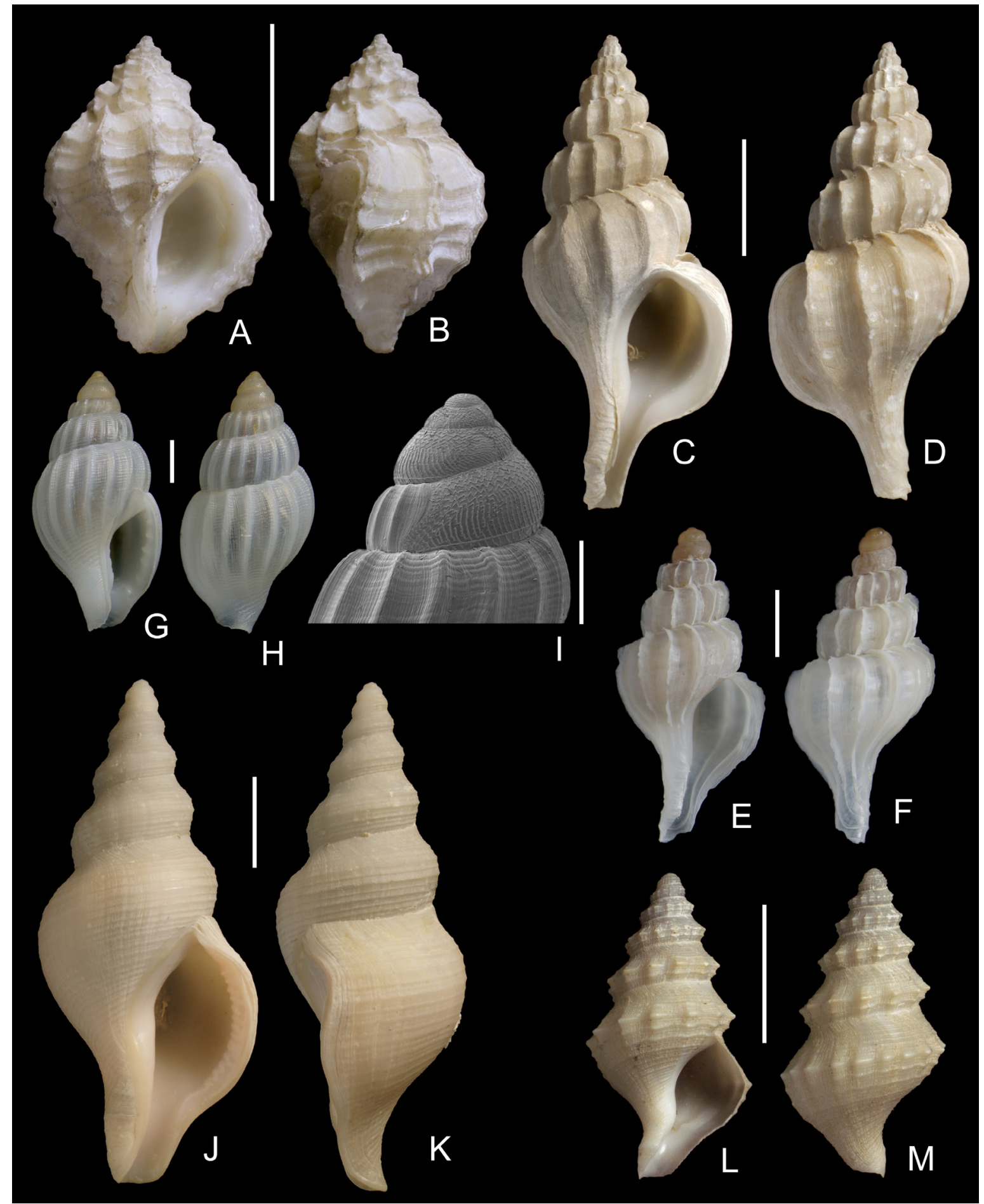

Fig. 23. Muricidae, Fasciolariidae, Columbellidae, Buccinidae, Colidae. A-B. Coralliophila richardi (P. Fischer, 1882), SEAMOUNT 1, DW106, 765 m, 17.9 mm. C-D. Boreotrophon dabneyi (Dautzenberg, 1889), BANGAL 0711, V5, $1631 \mathrm{~m}, 40.8 \mathrm{~mm}$. E-F. B. dabneyi, juvenile specimen with well-preserved brown protoconch, BANGAL 0711, V2, $1706 \mathrm{~m}, 4.7 \mathrm{~mm}$. G-H. Amphissa acutecostata (Philippi, 1844), SEAMOUNT 1, DW116, 985-1000 m, $6.0 \mathrm{~mm}$. I. A. acutecostata, protoconch of another specimen, SEAMOUNT 1, CP117, 770 m. J-K. Troschelia berniciensis (King, 1846), ECOMARG 0709, V4, 735 m, 55 mm. L-M. Kryptos koehleri (Locard, 1896), BANGAL 0711, V8, 1565 m, 22.0 mm. Scale bars: A-D, J-M = $10 \mathrm{~mm}$; E-H = $1 \mathrm{~mm} ; \mathrm{I}=500 \mu \mathrm{m}$. 


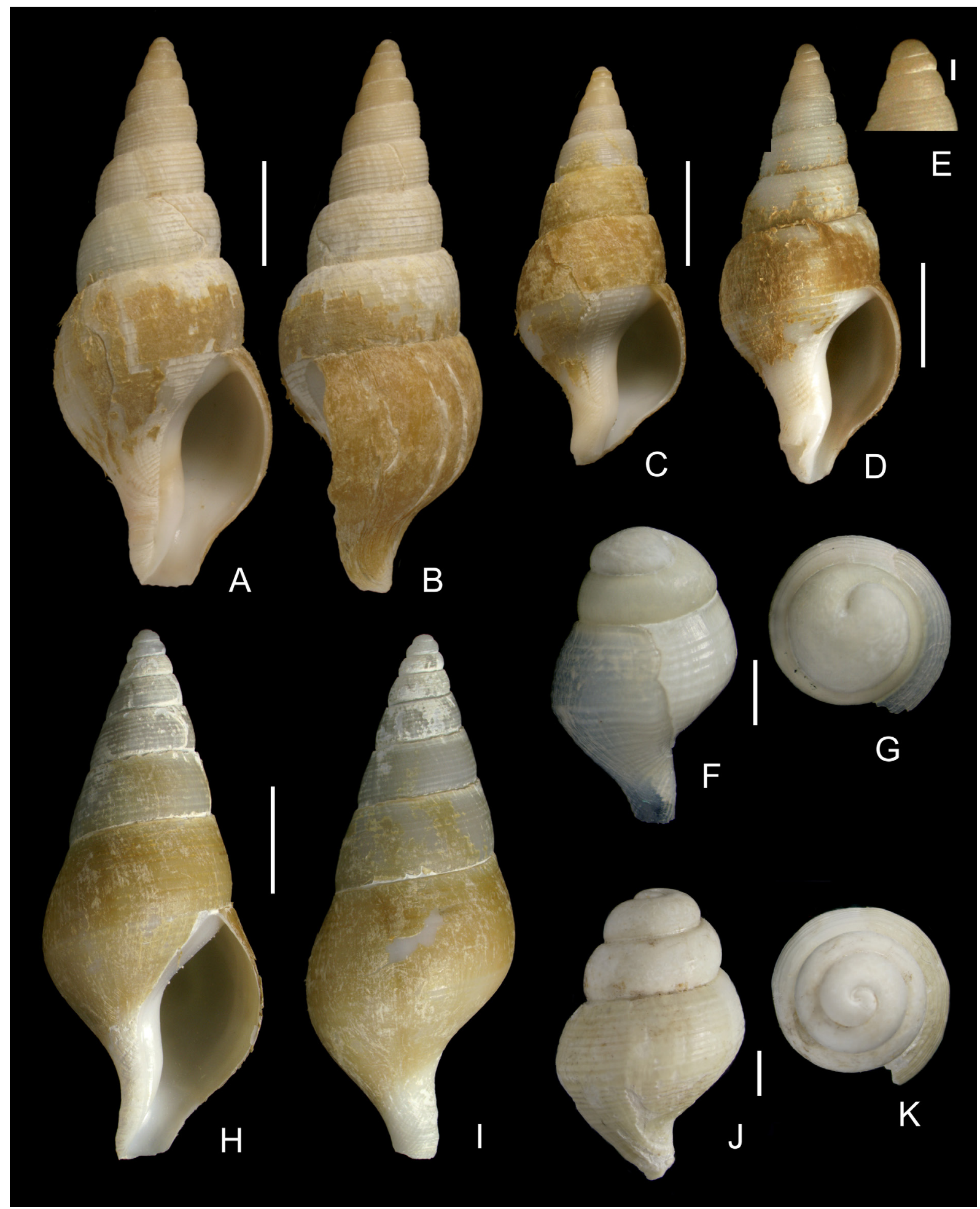

Fig. 24. Colidae. A-D. Colus gracilis (da Costa, 1778), ECOMARG 0709, R2, 615 m, 52 mm, $38 \mathrm{~mm}$ and $42 \mathrm{~mm}$. E. Detail of apical whorls, same specimen as D. F-G. C. gracilis, juvenile shell with protoconch and half teleoconch whorl, BANGAL 0711, V4, $744 \mathrm{~m}, 4.5 \mathrm{~mm}$. H-I. Colus jeffreysianus (P. Fischer, 1868), BANGAL 0711, V10, $1720 \mathrm{~m}, 49.3 \mathrm{~mm}$. J-K. C. jeffreysianus, juvenile shell with protoconch and half teleoconch whorl, $6.5 \mathrm{~mm}$, from the same locality. Scale bars: A-D, $\mathrm{H}-\mathrm{I}=10 \mathrm{~mm}$; $\mathrm{E}-\mathrm{G}, \mathrm{J}-\mathrm{K}=1 \mathrm{~mm}$. 
2. Sculpture mostly spiral, shell commonly $>5 \mathrm{~cm}$

Troschelia berniciensis (King, 1846) (Fig. 23J-K)

- Sculpture with conspicuous knobs along the periphery Kryptos koehleri (Locard, 1896) (Fig. 23L-M)

3. Protoconch of little more than 1 whorl, with a large nucleus

Colus gracilis (da Costa, 1778) (Fig. 24A-G)

- Protoconch of more than 2 whorls, with a small nucleus

Colus jeffreysianus (P. Fischer, 1868) (Fig. 24H-K)

\section{Remarks}

There are two species of Colus Röding, 1798 to be found on GB (Fig. 24), and their correct identification is crucial since they are an important component of the benthic community and food chain. Both have extremely similar shells and their accurate identification relies essentially on the diagnostic character of the protoconch. Colus gracilis is found on the summit platform and the adult is somewhat larger and more solid, whereas $C$. jeffreysianus has a broad distribution on the deeper part of the slope. Colus aurariae Fraussen, Rosado, Afonso \& Monteiro, 2009, described from off Portugal in 200-500 m depth, differs from C. gracilis in having both early whorls and siphonal canal more stretched out; it was not found on GB.

Family Cancellariidae Forbes \& Hanley, 1851

Genus Brocchinia Jousseaume, 1887

\section{Type species}

Voluta mitraeformis Brocchi, 1814, by monotypy.

Brocchinia cf. clenchi Petit, 1986

Fig. 25A-E

Brocchinia clenchi Petit, 1986: 23-26.

Brocchinia clenchi - Verhecken 2007: 311-313.

\section{Material examined}

GALICIA BANK • $5 \mathrm{spm}$ and $7 \mathrm{sh} ; 43^{\circ} 00.12^{\prime} \mathrm{N}, 11^{\circ} 57.67^{\prime} \mathrm{W} ; 1706 \mathrm{~m}$; 29 Jul. 2011; BANGAL 0711 $\mathrm{V} 2$; MNCN • $5 \mathrm{sh} ; 42^{\circ} 56.77^{\prime} \mathrm{N}, 11^{\circ} 58.53^{\prime} \mathrm{W}$; $1631 \mathrm{~m}$; 2 Aug. 2011; BANGAL 0711 V5; MNCN • $1 \mathrm{spm}$ (Fig. 25A-B, $10.8 \mathrm{~mm}$ high); 42 $59.61^{\prime} \mathrm{N}, 1^{\circ} 58.41^{\prime} \mathrm{W}$; $1671 \mathrm{~m}$; 7 Aug. 2011; BANGAL $0711 \mathrm{~V} 9$; MNCN • $1 \mathrm{spm}, 6 \mathrm{sh} ; 42^{\circ} 41.87^{\prime} \mathrm{N}, 1^{\circ} 26.71^{\prime} \mathrm{W} ; 1720 \mathrm{~m} ; 8$ Aug. 2011; BANGAL $0711 \mathrm{~V} 10$; MNCN • $5 \mathrm{sh} ; 42^{\circ} 28.81^{\prime} \mathrm{N}, 11^{\circ} 50.03^{\prime} \mathrm{W}$; $1410 \mathrm{~m}$; 8 Aug. 2011; BANGAL $0711 \mathrm{DR} 15$; MNCN.

\section{Description}

Shell rather solid, creamy white, conical and elongated, up to $10.8 \mathrm{~mm}$ in height, $5.4 \mathrm{~mm}$ width. Protoconch paucispiral, globose, of $1 \frac{1}{2}$ whorl, $330 \mu \mathrm{m}$ in nucleus diameter and about $650 \mu \mathrm{m}$ in maximum diameter, smooth, with a clear thickened edge marking the transition to teleoconch. Teleoconch with up to 5 convex whorls, first whorl with 2 initially smooth and then slightly nodulose spiral cords, with third cord appearing at the end of this whorl. Spiral sculpture formed by 3 nodulose spiral cords on last 2 whorls, and 3-4 more basal cords almost smooth on body whorl; uppermost basal cord meeting a level close to the suture at the posterior end of aperture. Axial sculpture formed by nodulose ribs, crossed by the three equally spaced upper spiral cords. Shell entirely marked by strong axial growth lines. Suture 


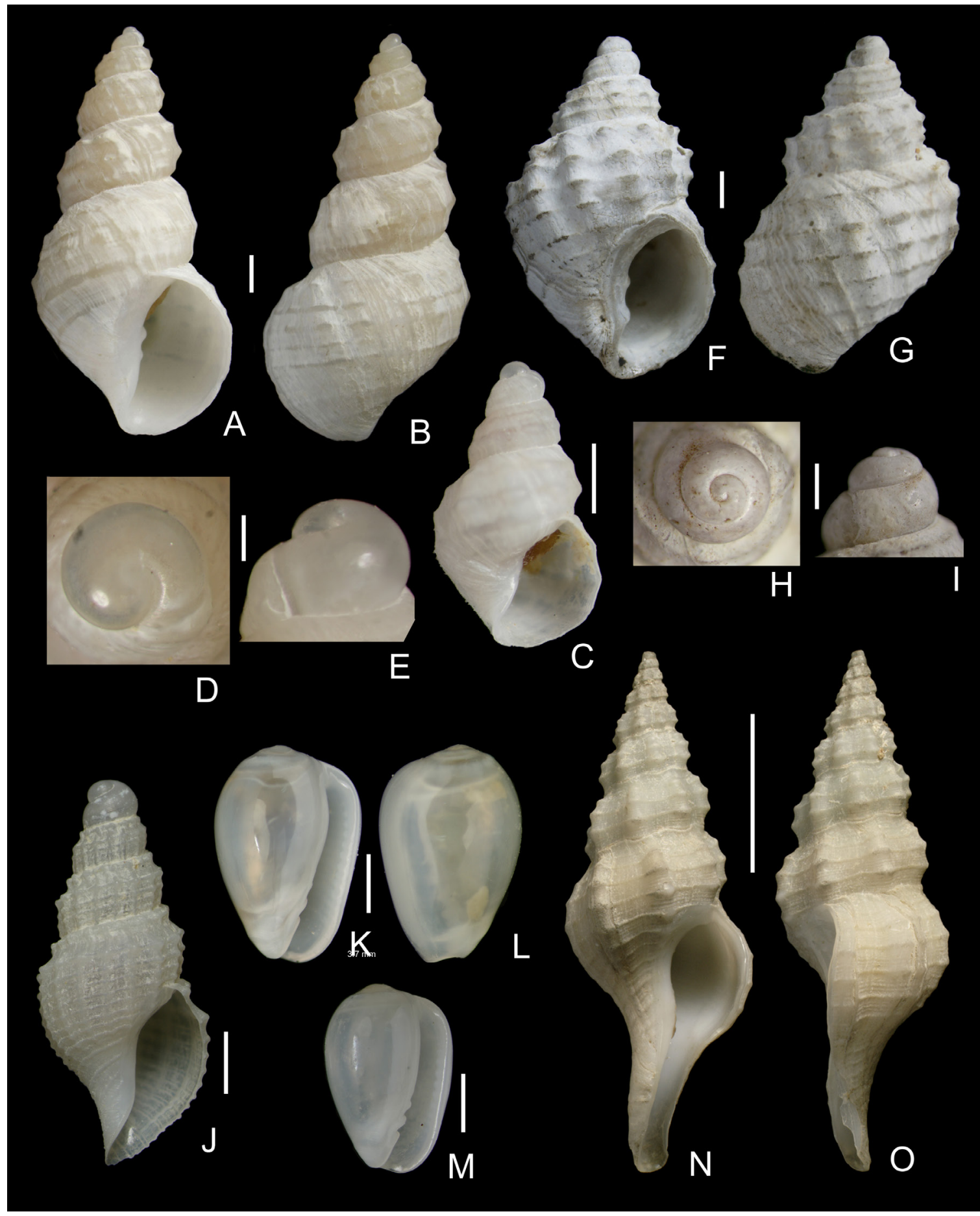

Fig. 25. Cancellariidae, Belomitridae, Cystiscidae, Fasciolariidae. A-B. Brocchinia cf. clenchi Petit, 1986, BANGAL 0711, V9, $1671 \mathrm{~m}$, live collected specimen, $10.8 \mathrm{~mm}$. C. Brocchinia cf. clenchi, juvenile specimen, BANGAL 0711, V2, $1706 \mathrm{~m}, 4.1 \mathrm{~mm}$. D-E. Same specimen, detail of the protoconch. F-G. Brocchinia azorica (Bouchet \& Warén, 1985), BANGAL 0711, V5, $1631 \mathrm{~m}, 9.3 \mathrm{~mm}$. H-I. Detail of the protoconch of another shell, BANGAL 0711, V2. J. Belomitra quadruplex (Watson, 1882), BANGAL 0711, V10, 1720 m, 6.2 mm. K-M. Gibberula abyssicola Locard, 1897, SEAMOUNT 1, DW116, 985-1000 m, 3.7 and 3.2 mm. N-O. Fusinus bocagei (P. Fischer, 1882), ECOMARG 0709, V4, $735 \mathrm{~m}, 33 \mathrm{~mm}$. Scale bars:A-C, F-G, J-M = $1 \mathrm{~mm}$; D-E, $\mathrm{H}-\mathrm{I}=200 \mu \mathrm{m} ; \mathrm{N}-\mathrm{O}=10 \mathrm{~mm}$. 
incised, with suprasutural furrow. Base conical, with 2 smooth spiral cords that emerge from the interior of the aperture. Aperture elliptical, outer lip thin, prosocline, smooth inside. Inner lip strongly reflected, with a thin and shiny vitreous callus on the parietal area. Columella somewhat inclined to right, with 2 strong folds, posterior larger, columellar end somewhat angled at its end and forming a weak siphonal canal when it meets the outer lip.

\section{Remarks}

Specimens and shells of this species were only found in the deepest BANGAL samples (1631-1720 m), together with shells of Brocchinia azorica (Bouchet \& Warén, 1985) in samples V2 and V5.

Brocchinia clenchi Petit, 1986 was originally described from the Josephine Bank at 610-770 m depth (Petit 1986); the holotype being faintly sculptured and measuring $4.5 \mathrm{~mm}$. The species was later found deeper (1350-1360 m) in the same locality; shells and specimens were recorded from the Canary Islands $(65-1520 \mathrm{~m})$, Selvagem Grande (830 m), Azores (15-1250 m) and off Western Sahara (1000-1100 m) (Verhecken 2002, 2007). Both extremes of the bathymetric range (15-1520 m) are based on live collected specimens (Verhecken 2007).

Verhecken (2007: fig. 29c-d) illustrated as B. clenchi two larger and more sculptured shells in a lot of six collected in PORCUPINE stn 28 (S of Sagres, 548 m, BMNH 1885.11.5.2607-12), which are closely similar to those from GB and were identified by Jeffreys (1885: 49) as 'Cancellaria mitraeformis, Brocchi'. Verhecken (2007) noted that shells of B. clenchi of similar size coming from shallow or deep waters of the Canary Islands may be faintly or strongly sculptured, whereas shells from deeper water were larger (up to $8.5 \mathrm{~mm}$ ). He nevertheless preferred to consider one species awaiting for more material from different localities. In disagreement with this view, Rolán \& Hernández (2009) described Brocchinia canariensis as different from $B$. clenchi. These authors also concluded that the paratype of $B$. clenchi (a shell of $6 \mathrm{~mm}, \mathrm{BMNH}$ 1855.4.4.202, from the Canary Islands) illustrated by Petit (1986), as "possibly the type of Cancellaria pusilla H. Adams, 1869" (a junior primary homonym of Cancellaria pusilla G.B. Sowerby I, 1832) was different from both B. clenchi and B. canariensis, therefore their choice to describe a new species from the Canaries rather than propose a replacement name for C. pusilla.

Other N Atlantic species, as Brocchinia azorica (Bouchet \& Warén, 1985) (see Fig. 25F-I), B. pustulosa Verhecken, 1991, and B. nodosa (Verrill \& S. Smith, 1885) have the inside of the outer lip smooth, but are larger and have a more solid and conical shell with stronger nodulose sculpture; $B$. azorica and B. nodosa also have multispiral protoconchs. The $\mathrm{S}$ Atlantic $B$. decapensis (Barnard, 1960) is the largest Atlantic species (up to $27.3 \mathrm{~mm}$ ), and has also a more solid and conical shell. Finally, the NE Brazilian species Brocchinia verheckeni Barros \& Lima, 2007 and B. harasewychi Barros \& Lima, 2007, have a paucispiral protoconch, but they are smaller (up to 4.4 and $6.3 \mathrm{~mm}$, respectively), less elongated than the species from GB, and have a stronger nodulose sculpture; $B$. verheckeni has lyrae inside the outer lip, whereas B. harasewychi lacks them (see Barros \& Lima 2007).

\section{Superfamily Conoidea Fleming, 1822}

This species-rich superfamily is represented on Galicia Bank by members of the families Cochlespiridae Powell, 1942 (Aforia Dall, 1889), Borsoniidae Bellardi, 1875 (Drilliola Locard, 1897, Retidrillia J.H. McLean, 2000), Mangeliidae P. Fischer, 1883 (Kurtziella Dall, 1918), and mostly Raphitomidae Bellardi, 1875 (Pleurotomella Verrill, 1872, Gymnobela Verrill, 1884, Austrobela Criscione, Hallan, Puillandre \& Fedosov, 2020, Teretia Norman, 1888, Neopleurotomoides Shuto, 1971). The separation of Pleurotomella species is very difficult, Bouchet \& Warén (1980) should be consulted for identification in this genus. 


\section{Key to the species of Conoidea found in the GB}

1. Sculpture formed by clearly predominant spiral cords or keels ................................................... 2

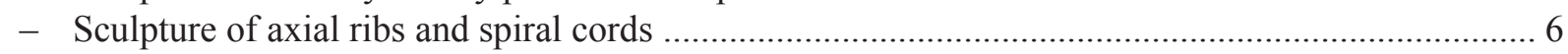

2. Shell up to $35 \mathrm{~mm}$ high, with two keels and finer spiral threads

Aforia serranoi Gofas, Kantor \& Luque, 2014 (Fig. 26A-C)

- Shell usually less than $10 \mathrm{~mm}$, not keeled or with only one subsutural keel ................................... 3

3. Last whorl hardly more than half of total height, protoconch ribbed

Drilliola loprestiana (Calcara, 1841) (Fig. 26F-G)

- Last whorl nearly two-thirds of total height, protoconch not ribbed

4. Subsutural keel present; sometimes a very faint ribbing

Gymnobela subaraneosa (Dautzenberg \& H. Fischer, 1896) (Fig. 27I-J)

- No subsutural keel

5. Spiral cords coarse, protoconch small $<0.5 \mathrm{~mm}$ ..Teretia teres (Reeve, 1844) (Fig. 26N)

- Spiral cords fine, protoconch large $>0.7 \mathrm{~mm}$

Teretia megalembryon (Dautzenberg \& H. Fischer, 1896) (Fig. 26L-M)

6. Spiral sculpture comprising spiral cords, and finer spiral threads in the interspaces of the main cords

Kurtziella serga (Dall, 1881) (Fig. 27A-B)

- Spiral cords or threads maybe unequal, but not as above 7

7. Protoconch whitish, with a marked peripheral keel and axial riblets

...Neopleurotomoides callembryon (Dautzenberg \& H. Fischer, 1896) (Fig. 27E-F)

- Protoconch generally brownish, with a cris-cross microsculpture of oblique riblets ........................ 8

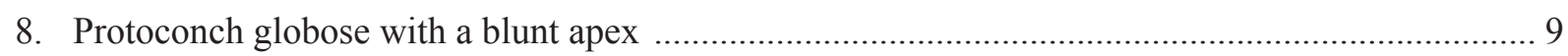

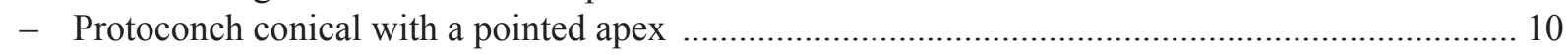

9. Whorls with a sharp keel bearing fine knobs ........ Retidrillia pruina (Watson, 1881) (Fig. 26D-E)

- Whorls bluntly angular, with definite flexuose ribs

Pleurotomella packardii Verrill, 1872 (Fig. 27C-D)

10. Shell robust, distinctly shouldered, with fine spiral cordlets and broader axial folds

- Shell thin, not distinctly shouldered, with spiral cords and axial ribs 12

11. Shell stout (diameter more than half the height), ribs few

Gymnobela abyssorum (Locard, 1897) (Fig. 26H-I)

- Shell slender (diameter less than half the height), ribs numerous Austrobela pyrrhogramma (Dautzenberg \& H. Fischer, 1896) (Fig. 26J-K)

12. Shell rather solid, brownish with faint spiral banding

- Shell white or vitreous except for brown protoconch

13. Ribs thin and flexuous, much narrower than interspaces; spiral cords delicate and also widely spaced ..Pleurotomella coelorhaphe (Dautzenberg \& H. Fischer, 1896) (Fig. 27K-L)

- Ribs rather robust, may be oblique but not definitely flexuous 
14. Ribs and cords forming a definite lattice, with interspaces about twice as broad as those; ribs ca 12 on last whorl Pleurotomella eurybrocha (Dautzenberg \& H. Fischer, 1896) (Fig. 27M-N)

- Ribs and cords with interspaces only slightly broader than them, ribs ca, 20 on last whorl Pleurotomella demosia (Dautzenberg \& H. Fischer, 1896) (Fig. 27O-P)

Subclass Heterobranchia Family Pyramidellidae Gray, 1840

Members of the family Pyramidellidae, all of which are ectoparasites on other invertebrates (mostly annelids and molluscs), are unusually rare on GB, totalizing only 3 specimens and 8 shells.

Genus Tiberia Jeffreys, 1884

\section{Type species}

Pyramidella minuscula Monterosato, 1880, by subsequent designation.

\section{Tiberia sp.}

Fig. 28D-F

\section{Material examined}

GALICIA BANK • $1 \mathrm{spm}, 2 \mathrm{sh} ; 42^{\circ} 41.87^{\prime} \mathrm{N}, 1^{\circ} 26.71^{\prime} \mathrm{W} ; 1720 \mathrm{~m}$; 8 Aug. 2011; BANGAL $0711 \mathrm{~V} 10$; MNCN.

\section{Remarks}

The genus Tiberia is diagnosed by being umbilicate and having a straight columella with three folds, of which the two abapical ones are inconspicuous. The type species Pyramidella minuscula Monterosato, 1880 has a rather thick shell with brown spiral bands, one below the suture and another one above it, prolonged on the middle part of the last whorl. One specimen collected in $1720 \mathrm{~m}$ deep on GB (Fig. 28D-F) is definitely a Tiberia but differs from T. minuscula in being colourless, and in having a very thin shell with a markedly keeled last whorl.

Pyramidella curtissima Locard, 1897, described from deep water (Travailleur 1881, stn 3, 3307 m; stn 30, $1203 \mathrm{~m}$; Travailleur 1882, stn 13, $2030 \mathrm{~m}$ ) off Portugal, is much stouter than the specimen illustrated here. The figured syntype could not be traced in the "Travailleur" and "Talisman" collection of MNHN, Paris; one shell with no indication of station number, labelled "Portugal" (Fig. 28G) is in poor condition, and four other shells from "Travailleur" 1881 stn 31 (not mentioned in Locard 1897) are the rissoid Benthonella tenella.

Without additional material at hand, the observed differences are not sufficient to demonstrate that our specimen is specifically distinct from T. minuscula and it is therefore reported as Tiberia sp.

Genus Turbonilla Risso, 1826

\section{Type species}

Turbonilla costulata Risso, 1826, by subsequent designation.

Turbonilla cf. paucistriata (Jeffreys, 1884)

Fig. $28 \mathrm{H}$

\section{Material examined}

GALICIA BANK • $1 \mathrm{spm}, 1 \mathrm{sh}$; 42 $2^{\circ} 56.77^{\prime} \mathrm{N}, 1^{\circ} 58.53^{\prime} \mathrm{W}$; $1631 \mathrm{~m}$; 2 Aug. 2011; BANGAL $0711 \mathrm{~V} 5$; MNCN • 2 sh; $42^{\circ} 41.87^{\prime} \mathrm{N}, 1^{\circ} 26.71^{\prime} \mathrm{W} ; 1720 \mathrm{~m}$; 8 Aug. 2011; BANGAL $0711 \mathrm{~V} 10$; MNCN. 


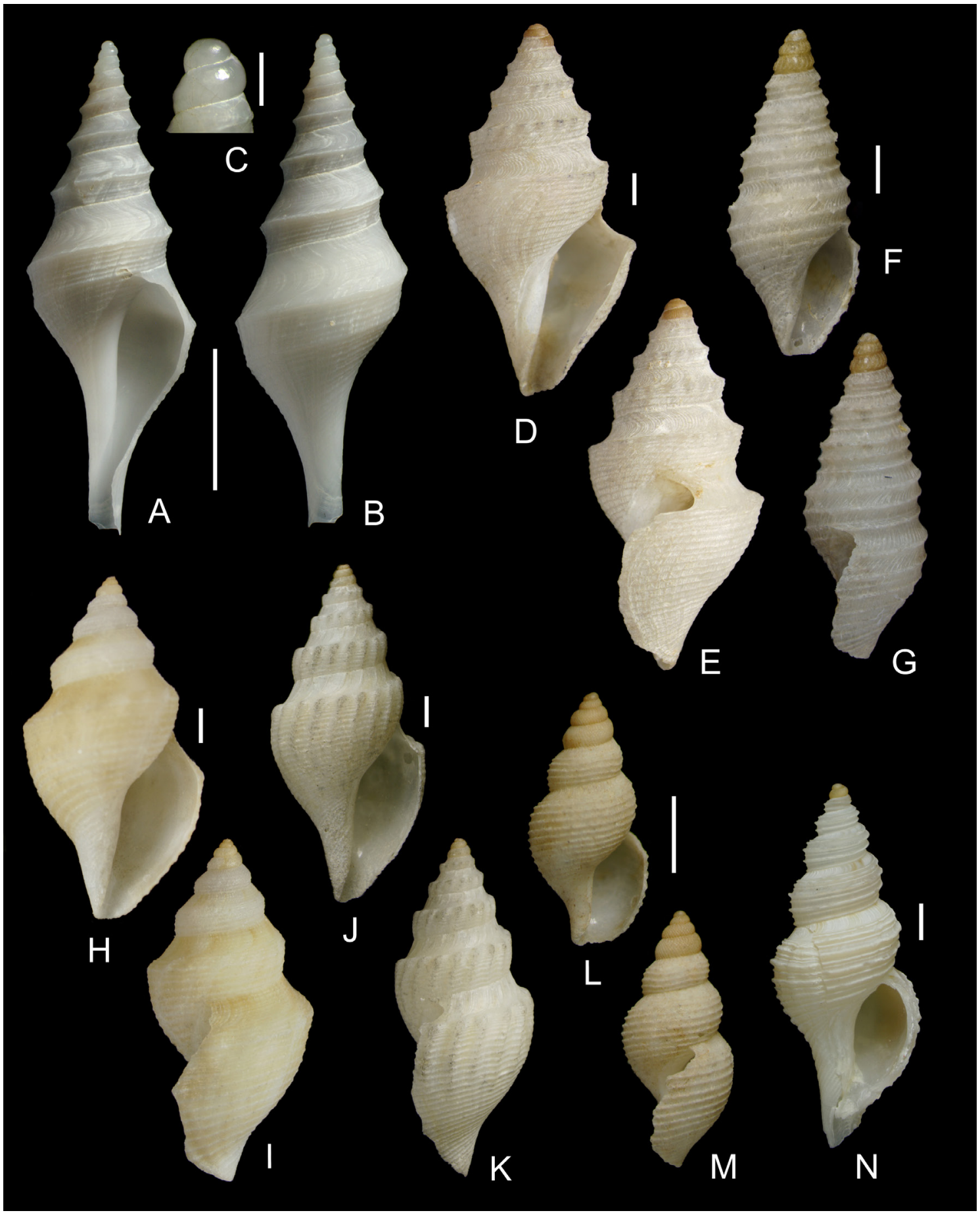

Fig. 26. Conoidea 1 (Cochlespiridae, Borsoniidae, Raphitomidae). A-C. Aforia serranoi Gofas, Kantor \& Luque, 2014, holotype, BANGAL 0711, V10, $1720 \mathrm{~m}, 35 \mathrm{~mm}$, and detail of the protoconch. D-E. Retidrillia pruina (Watson, 1881), BANGAL 0711, V5, $1631 \mathrm{~m}, 11.7 \mathrm{~mm}$. F-G. Drilliola loprestiana (Calcara, 1841), SEAMOUNT 1, DW108, 1110-1125 m, $6.8 \mathrm{~mm}$. H-I. Gymnobela abyssorum (Locard, 1897), SEAMOUNT 1, DW116, 985-1000 m, $10.0 \mathrm{~mm}$. J-K. Austrobela pyrrhogramma (Dautzenberg \& H. Fischer, 1896), SEAMOUNT 1, DW116, $10.8 \mathrm{~mm}$. L-M. Teretia megalembryon (Dautzenberg \& H. Fischer, 1896), SEAMOUNT 1, DW116, 985-1000 m, 3.3 mm. N. Teretia teres (Reeve, 1844), SEAMOUNT 1, DW106, $765 \mathrm{~m}, 10.1 \mathrm{~mm}$. Scale bars: A-B = $10 \mathrm{~mm}$; $\mathrm{C}-\mathrm{N}=1 \mathrm{~mm}$. 


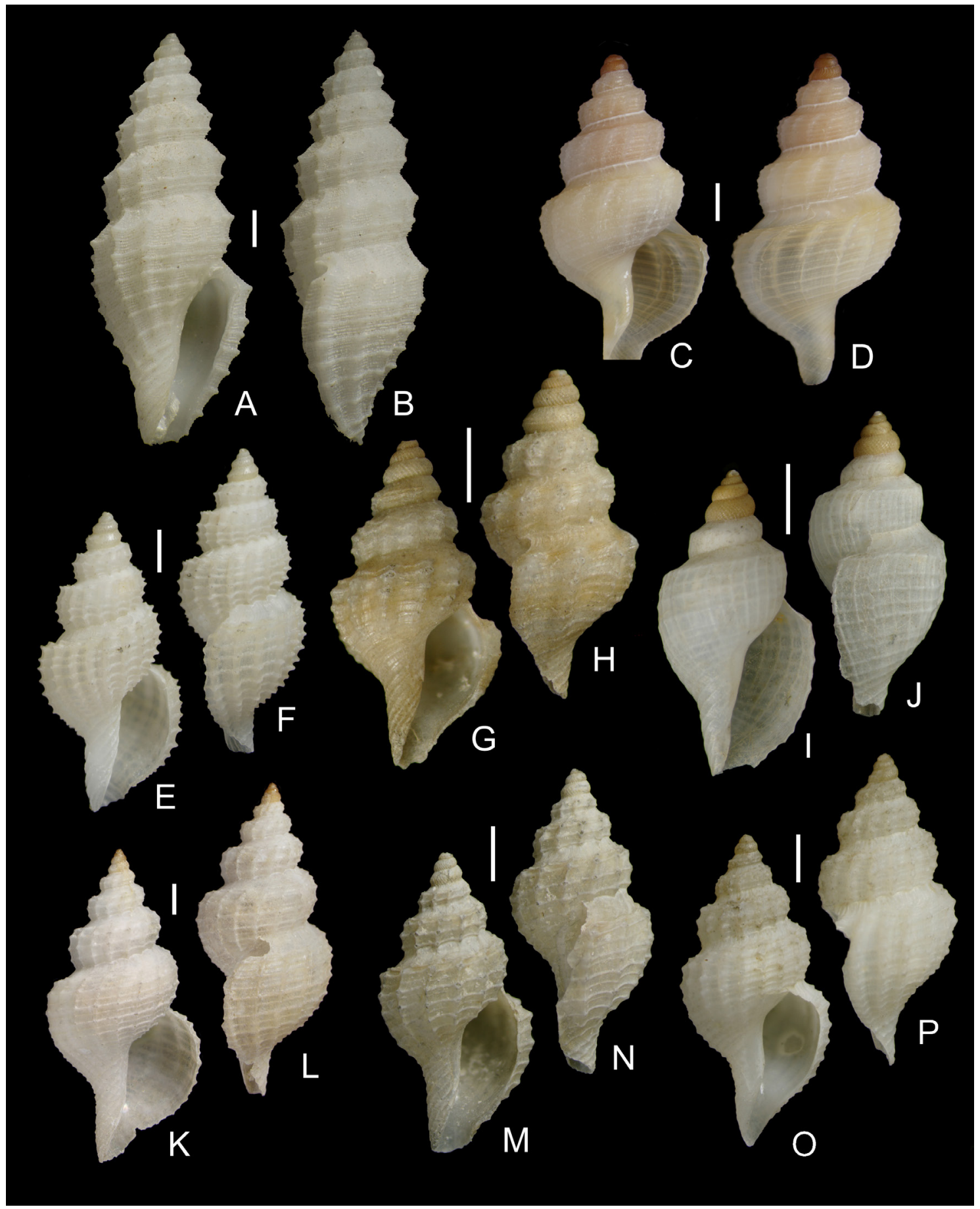

Fig. 27. Conoidea 2 (Mangeliidae, Raphitomidae). A-B. Kurtziella serga (Dall, 1881), SEAMOUNT 1, DW115, 880-885 m, 11.3 mm. C-D. Pleurotomella packardii Verrill, 1872, BANGAL 0711, V2, 1706 m, $8.9 \mathrm{~mm}$. E-F. Neopleurotomoides callembryon (Dautzenberg \& H. Fischer, 1896), SEAMOUNT 1, DW111, 675-685 m, 7.1 mm. G-H. Pleurotomella gibbera Bouchet \& Warén, 1980, SEAMOUNT 1, DW116, 985-1000 m, $4.2 \mathrm{~mm}$. I-J. Gymnobela subaraneosa (Dautzenberg \& H. Fischer, 1896), SEAMOUNT 1, DW116, 4.3 mm. K-L. Pleurotomella coelorhaphe (Dautzenberg \& H. Fischer, 1896), SEAMOUNT 1, DW116, $10.0 \mathrm{~mm}$. M-N. Pleurotomella eurybrocha (Dautzenberg \& H. Fischer, 1896), SEAMOUNT 1, DW108, 1110-1125 m, 5.5 mm. O-P. Pleurotomella demosia (Dautzenberg \& H. Fischer, 1896), SEAMOUNT 1, DW111, $6.5 \mathrm{~mm}$. Scale bars $=1 \mathrm{~mm}$. 


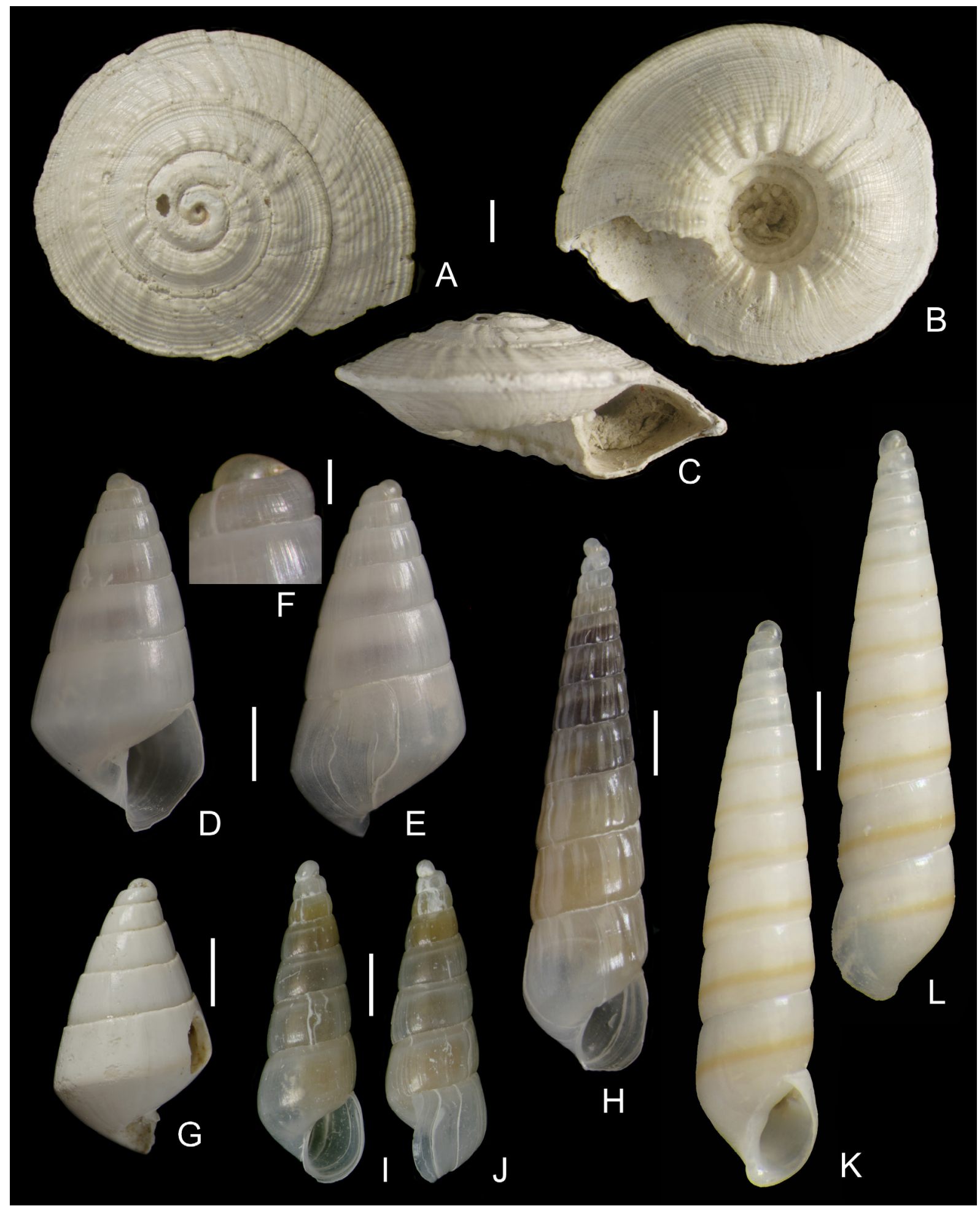

Fig. 28. Heterobranchia 1 (Architectonicidae, Pyramidellidae). A-C. Solatisonax hemisphaerica (Seguenza, 1876), BANGAL 0711, V6, 909 m, 8.9 mm. D-F. Tiberia sp., BANGAL 0711, V10, 1720 m, $4.8 \mathrm{~mm}$. G. Syntype of Pyramidella curtissima Locard, 1897, Travailleur 1881 or 1882, $4.0 \mathrm{~mm}$. H. Turbonilla cf. paucistriata (Jeffreys, 1884), BANGAL 0711, V5, $1631 \mathrm{~m}, 7.8 \mathrm{~mm}$. I-J. Eulimella sp., BANGAL 0711, V10, 5.3 mm. K-L. Tibersyrnola unifasciata (Forbes, 1844), BANGAL 0711, V6, $7.2 \mathrm{~mm}$. Scale bars: A-E, G-L=1 mm; $\mathrm{F}=200 \mu \mathrm{m}$. 


\section{Remarks}

The single specimen and three shells resemble Turbonilla paucistriata (Jeffreys, 1884), originally described from much shallower depth of the Mediterranean (in the Sicily Channel), but differ in being more slender and having a more distinctly protruding protoconch, also of van Aartsen's (1987) "type B" i.e., with coiling axis making an angle of ca $100^{\circ}$ with teleoconch axis. Turbonilla amoena (Monterosato, 1878) is also similar but broader. Not much more can be said without additional material from the area.

Family Ringiculidae Philippi, 1853

Genus Ringicula Deshayes, 1838

\section{Type species}

Marginella auriculata Ménard de la Groye, 1811, by subsequent designation.

Ringicula nitida Verrill, 1872

Fig. $29 \mathrm{~F}-\mathrm{G}$

Ringicula nitida Verrill, 1872: 16.

Ringicula nitida-Bouchet 1975: 329-331.

\section{Material examined}

GALICIA BANK • $20 \mathrm{sh} ; 43^{\circ} 00.12^{\prime} \mathrm{N}, 11^{\circ} 57.67^{\prime} \mathrm{W} ; 1706 \mathrm{~m}$; 29 Jul. 2011; BANGAL $0711 \mathrm{~V} 2$; MNCN - $1 \mathrm{sh} ; 4^{\circ} 56.77^{\prime} \mathrm{N}, 11^{\circ} 58.53^{\prime} \mathrm{W}$; $1631 \mathrm{~m}$; 2 Aug. 2011; BANGAL $0711 \mathrm{~V} 5 ; \mathrm{MNCN} \bullet 1 \mathrm{sh} ; 42^{\circ} 59.61^{\prime} \mathrm{N}$,

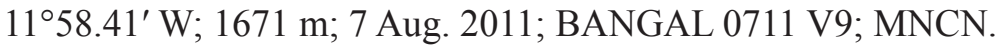

\section{Remarks}

Bouchet (1975) considered several deep-sea species of Ringicula as synonyms of $R$. nitida and, based on this, cited that species from several localities off the northwestern Iberian Peninsula, including GB. However, Mariottini et al. (2000) considered R. nitida as restricted to the Western Atlantic and referred the records by Bouchet (1975) to R. gianninii Nordsieck, 1974, which differs by having a higher spire, more convex whorls, and by forming a parietal tooth ("columellar tooth" in Mariottini et al. 2000) which R. nitida does not have. However, the specimens collected on GB have a low spire with slightly convex whorls and lack a parietal tooth, therefore being so similar to the lectotype of the American species (Mariottini et al. 2000: fig. 7) that, except for the geographic distance, we see no reason for their specific separation with the material at hand. The only difference observed is the number of spiral striae, which are around 30 in GB shells, less conspicuous in the abapical part of the whorls, while they are about 14 in the lectotype of $R$. nitida. Bearing in mind that most of the other heterobranchs present in the area such as Acteon monterosatoi Dautzenberg, 1889, Crenilabium exile (Jeffreys, 1870), Pyrunculus ovatus (Jeffreys, 1871) and Scaphander punctostriatus (Mighels \& C.B. Adams, 1842) are considered amphiatlantic, we find more prudent to assign these specimens, tentatively, to $R$. nitida rather than describe them as a new species.

Ringicula crassidens Gofas \& Luque sp. nov. urn:1sid:zoobank.org:act:8E4FB886-47AD-479C-9B49-238DD01F4F27

Fig. $29 \mathrm{H}-\mathrm{K}$

\section{Etymology}

The specific name refers to the characteristic columellar folds ('crassidens', thick teeth). 
GOFAS S. et al., Mollusca of Galicia Bank

\section{Type material}

\section{Holotype}

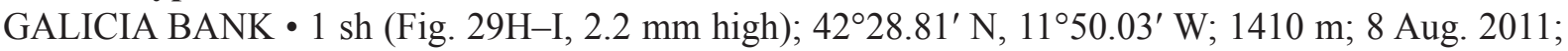
BANGAL 0711 DR15; MNCN 15.05/200140H.

\section{Paratypes}

GALICIA BANK • $3 \mathrm{sh}$; same collection data as for holotype; MNCN 15.05/200140P.

\section{Other material examined}

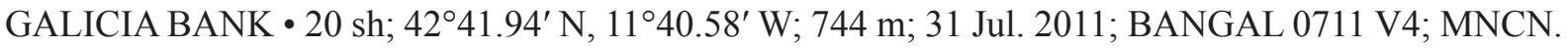

\section{Description}

Shell small (holotype height $2.2 \mathrm{~mm}$ ), semi-transparent, not very solid, globose, with a well defined suture and moderately elevated spire. Protoconch of a little more than half a whorl, smooth, without microsculpture even at high magnification. Teleoconch formed by $2 \frac{1}{2}$ whorls, the first one almost smooth, the last with about 38-40 well marked, irregularly spaced spiral grooves which, under high magnification, appear as continuous series of square pits, and also with very fine growth lines; in the holotype there is also a growth stage in the last half whorl. Aperture slightly more than $2 / 3$ of the total height, with two very marked columellar folds, the abapical one slightly larger, and with a very blunt and thick tooth in the middle of the parietal edge. Outer lip only slightly thickened, with a rounded edge. Very short siphonal canal. Colour uniformly white.

\section{Remarks}

This tiny species resembles Ringicula blanchardi Dautzenberg \& H. Fischer, 1896, described from the bathyal of the Azores, with which it shares the considerable development of the parietal tooth and the very clear spiral sculpture. It differs from it, however, because of its smaller size and more globose shape and lower spire with almost one whorl less. The great development of the parietal tooth, absent even in adults of $R$. nitida, indicates that, despite the scarce thickening of the outer lip, these are adult shells. The specimen from the GB reported by Rolán Mosquera (1983: 280) as Ringicula blanchardi Dautzenberg \& H. Fischer, 1896 is in such a bad state that it cannot be recognized.

Family uncertain

Genus Cylichnium Dall, 1908

\section{Type species}

Utriculus domitus Dall, 1889, by original designation.

Cylichnium oliviforme (Watson, 1883)

Fig. $30 \mathrm{H}-\mathrm{J}$

Utriculus oliviformis Watson, 1883: 332.

Utriculus sp. - Watson 1886: 648, pl. 48 fig. 6.

Utriculus oliviformis - Dautzenberg \& Fischer 1896: 400.

Cylichnium oliviforme (Watson, 1883) - Fechter 1979: 37-38.

\section{Material examined}

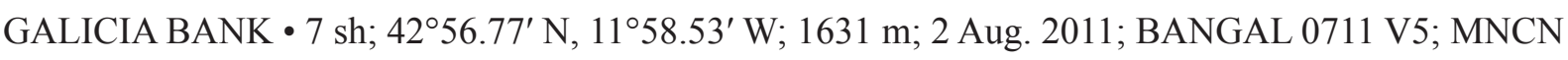

- $6 \mathrm{sh} ; 42^{\circ} 41.87^{\prime} \mathrm{N}, 1^{\circ} 26.71^{\prime} \mathrm{W}$; 1720 m; 8 Aug. 2011; BANGAL 0711 V10; MNCN. 


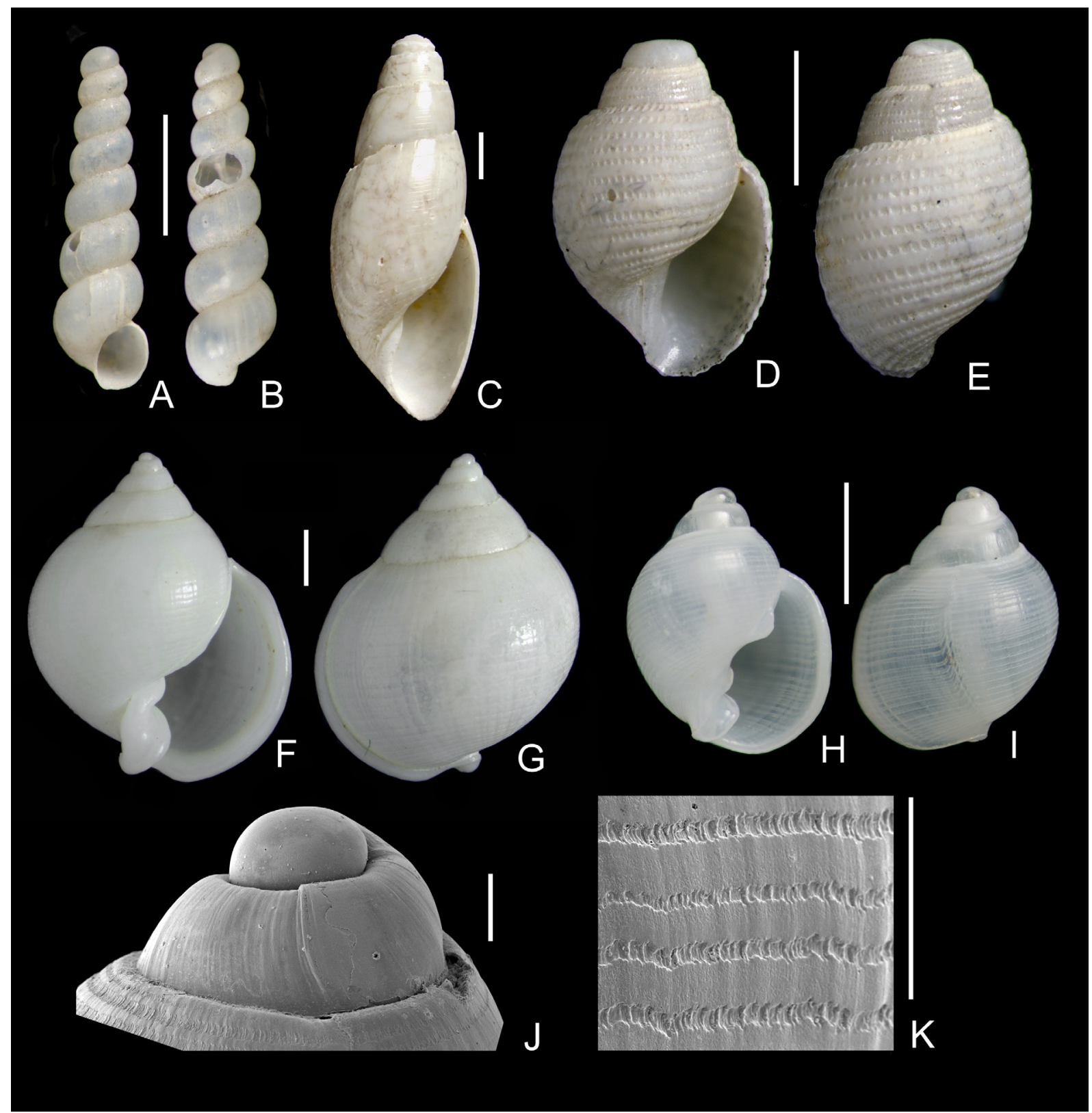

Fig. 29. Heterobranchia 2 (Cimidae, Acteonidae, Ringiculidae). A-B. Atomiscala islandica Warén, 1989, BANGAL 0711, DR15, 1410 m, 2.8 mm. C. Crenilabium exile (Jeffreys, 1870), BANGAL 0711, V10, 1720 m, 8.2 mm. D-E. Acteon monterosatoi Dautzenberg, 1889, SEAMOUNT 1, DW116, 985-1000 m, 2.5 mm. F-G. Ringicula nitida Verrill, 1872, BANGAL 0711, V2, 1706 m, 5.8 mm. H-I. Ringicula crassidens Gofas \& Luque sp. nov., holotype (MNCN 15.05/200140H), BANGAL 0711, DR15, $2.2 \mathrm{~mm}$ high. J. Protoconch of a paratype (MNCN 15.05/200140P), same locality. K. Microsculpture of the second teleoconch whorl, same shell as J. Scale bars: A-I $=1 \mathrm{~mm} ; \mathrm{J}-\mathrm{K}=100 \mu \mathrm{m}$. 


\section{Remarks}

This species was described tentatively by Watson (1883) and later retracted by Watson (1886) on the grounds of poor condition of the material examined, originating from off the Azores in 1000 fathoms $(1850 \mathrm{~m})$. The species was again found off the Azores by Dautzenberg \& Fischer (1896) and confirmed as valid. It was later reported from off the NW Iberian Peninsula by Fechter (1979) and transferred to the genus Cylichnium Dall, 1908. The size given 0.32 inches $(8.1 \mathrm{~mm})$ and the depth of the type locality are in good agreement with our material. Bouchet (1975) reported Cylichnium africanum (Locard, 1897)

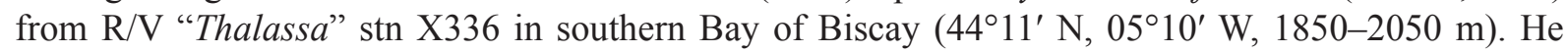
considered it distinct from Cylichnium oliviforme because, in his words, the latter is more distinctly flattened below the suture and has a finely reticulated sculpture in the upper part of the last whorl. Nevertheless, according to these characters we consider the shell figured by Bouchet (1975: pl. 4, c) as conspecific with our material. Conversely Locard (1897: pl. 2 figs 15-19) illustrated, to represent his Aceras africana, a shell in which the last whorl almost completely covers the spire whereas both the type of $C$. oliviforme and our specimens have a descending last whorl. Therefore, we follow Fechter (1979) in using the name $C$. oliviforme for the Iberian species.

Family Tornatinidae P. Fischer, 1883

Genus Acteocina Gray, 1847

\section{Type species}

Acteon wetherellii Lea, 1833, by original designation.

Acteocina interrogens Gofas \& Luque sp. nov. urn:lsid:zoobank.org:act:7B1EE4AD-8C25-4465-B07C-7E65B8F5F5C5

Fig. 30K-L

\section{Etymology}

The specific name refers to shape of the protoconch resembling a question mark.

\section{Type material}

\section{Holotype}

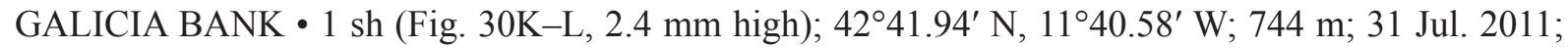
BANGAL 0711 V4; MNCN 15.05/200141H.

\section{Paratype}

GALICIA BANK • $1 \mathrm{sh}$; same collection data as for holotype; MNCN 15.05/200141P.

\section{Description}

Shell small (holotype height $2.4 \mathrm{~mm}$, diameter $1.2 \mathrm{~mm}$ ), opaque white, cylindrical with a protruding spire. Protoconch of about 1.5 rounded whorls, with a diameter of ca $300 \mu \mathrm{m}$, sinistral with a very low spire, its coiling axis forming an angle of ca $100^{\circ}$ with coiling axis of teleoconch, markedly protruding and distinctly demarcated from the teleoconch. The holotype has 2.5 teleoconch whorls, slightly convex, only ornamented with faint growth lines; last whorl being about $80 \%$ of total height in apertural view, and covering most of the previous teleoconch whorl, adapically with a sharp keel situated at a short distance from the suture and delimiting a flat subsutural shoulder. Aperture occupying two thirds of the total height, broadly rounded abapically and gradually narrowing adapically. Columella curved, continuous with the parietal wall, delimited by a very narrow callus. There is no umbilicus. External lip thin and cutting, straight in its median part, markedly curved at both ends. 


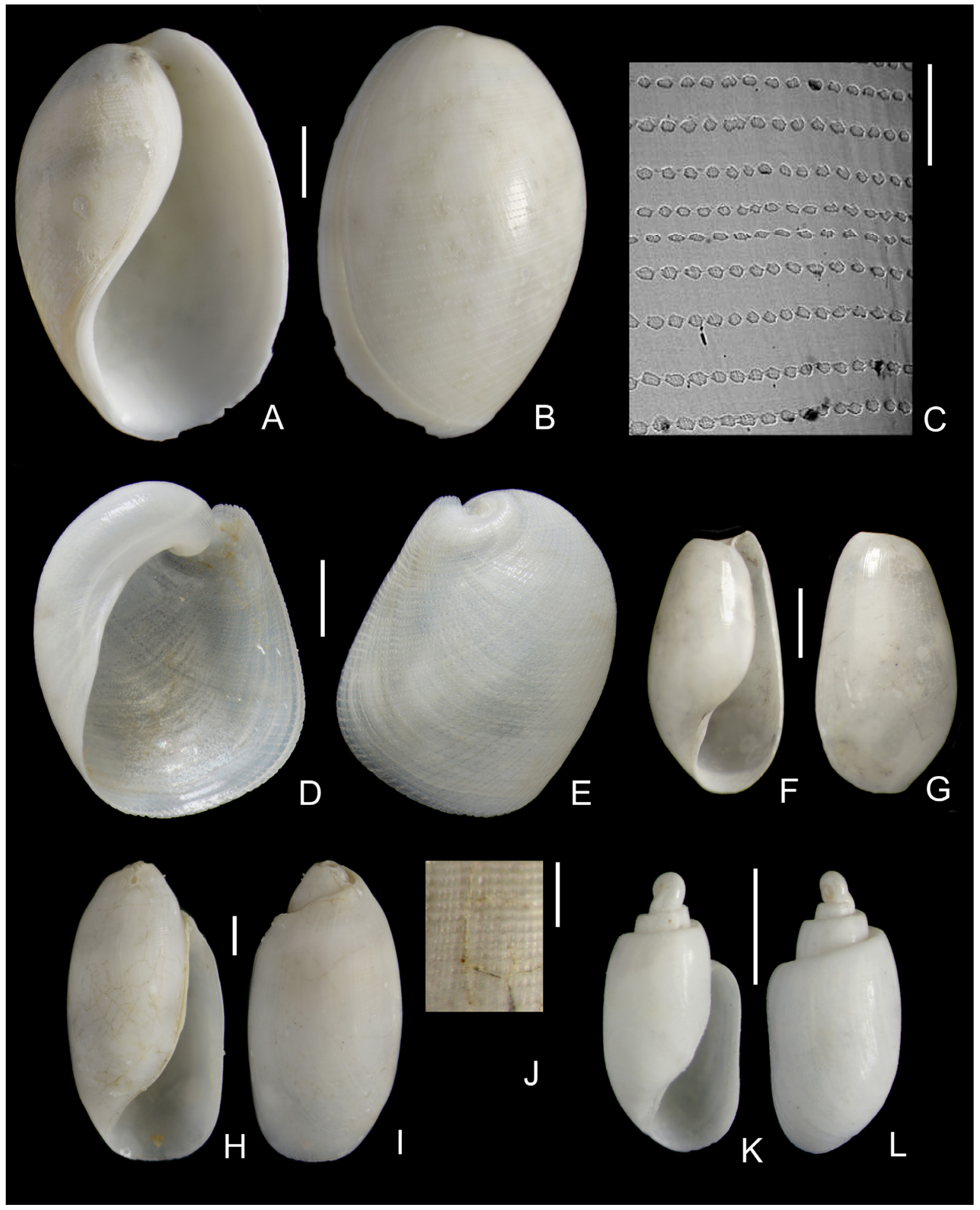

Fig. 30. Heterobranchia 3 (Scaphandridae, Philinidae, Retusidae). A-B. Scaphander punctostriatus (Mighels \& C.B. Adams, 1842), BANGAL 0711, V2, 1706 m. 5.8 mm. C. S. punctostriatus, SEM micrograph of the sculpture of the body whorl, BANGAL 0711, V5, $1631 \mathrm{~m}$. D-E. Laona quadrata (Wood, 1839), BANGAL 0711, V5, 4.4 mm. F-G. Pyrunculus ovatus (Jeffreys, 1871), BANGAL 0711, V5, $3.8 \mathrm{~mm}$. H-I. Cylichnium oliviforme (Watson, 1883), BANGAL 0711, V10, $1720 \mathrm{~m}, 7.6 \mathrm{~mm}$. J. Same specimen, detail of microsculpture of last whorl. K-L. Acteocina interrogens Gofas \& Luque sp. nov., holotype (MNCN 15.05/200141H), BANGAL 0711, V4, 744 m, 2.4 mm. Scale bars: A-B, D-I, $\mathrm{K}-\mathrm{L}=1 \mathrm{~mm} ; \mathrm{C}, \mathrm{J}=200 \mu \mathrm{m}$. 


\section{Remarks}

This species is so distinctive that we describe it despite the very scanty material. Acteocina knockeri (E.A. Smith, 1872), described from shallow water of Benin, West Africa, is twice as large, with a proportionally tiny hyperstrophic protoconch, and the adapical part of the whorls has two keels and bears axial folds which project, crown-like, on the subsutural flat. Acteocina protracta (Dautzenberg, 1889), described from deep water off the Azores, also has a much smaller protoconch and the last whorl accounts for $90 \%$ of total height in apertural view. We do not know of any Atlantic species approaching this GB species in shell morphology.

Class Bivalvia Linnaeus, 1758

Subclass Protobranchia Pelseneer, 1889

\section{Key to genera and species of Protobranchia found on GB}

See also Killeen \& Turner (2009) for identification of many North Atlantic Yoldiella Verrill \& Bush, 1897 and Ledella Verrill \& Bush, 1897 species not found in the present material.

1. Hinge plate narrowing but not interrupted under the umbo, with teeth forming a continuous series

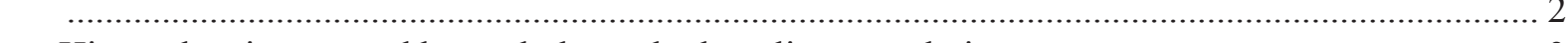

- Hinge plate interrupted beneath the umbo by a ligamental pit ....................................................... 3

2. Outline regularly oval, longer than high .................. Tindaria sericea (Jeffreys, 1876) (Fig. 31G-I)

- Outline rounded anteriorly and tapering posteriorly

Pseudoneilonella latior (Jeffreys, 1876) [not found on GB]

3. Outline triangular with rounded ends; inside of shell nacreous 4

- Outline rounded, oval, or with anterior end rounded and posterior end tapering; inside of shell not nacreous

4. Ventral margin smooth

Ennucula corbuloides (Seguenza, 1877) (Fig. 31E-F)

- Ventral margin crenulated by the termination of internal rods

5. Shell plump, externally with fine radial microsculpture

- Shell rather compressed, sculpture mostly commarginal

Nucula atacellana Schenck, 1939 (Fig. 31C-D)

Nucula tumidula Malm, 1861 (Fig. 31A-B)

6. Posterior end acute or more or less angular

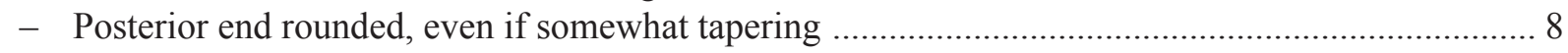

7. Posterior end acute, umbo anterior to vertical midline

Ledella messanensis (Jeffreys, 1870) (Fig. 32A-B)

- Posterior end bluntly angular, umbo posterior to vertical midline

Ledella cf. orixa (Dall, 1927) (Fig. 32C-D)

8. Shell less than $2 \mathrm{~mm}$, white, rounded in outline

Pristigloma minima (Seguenza, 1877) (Fig. 31J-K)

- Shell larger, definitely longer than high

9. Shell inflated, posteriorly tapering

Yoldiella semistriata (Jeffreys, 1879) (Fig. 32G-H)

- Shell very compressed, posterior part broadly rounded

Yoldiella valorousae Killeen \& J. A. Turner, 2009 (Fig. 32I-J) 
Family Nuculanidae H. \& A. Adams, 1858

Genus Ledella Verrill \& Bush, 1897

\section{Type species}

Ledella bushae Warén, 1978, by subsequent designation, ICZN Opinion 1306.

Ledella cf. orixa (Dall, 1927)

Fig. 32C-D

Leda orixa Dall, 1927: 8-9.

Ledella oxira [sic] (Dall, 1927) - Allen \& Hannah 1989: 148.

\section{Material examined}

GALICIA BANK • $1 \mathrm{sh} ; 42^{\circ} 37.77^{\prime} \mathrm{N}, 1^{\circ} 49.46^{\prime} \mathrm{W} ; 818 \mathrm{~m}$; 30 Jul. 2011; BANGAL $0711 \mathrm{~V} 3$; MNCN • $1 \mathrm{sh}, 45 \mathrm{v} ; 42^{\circ} 41.94^{\prime} \mathrm{N}, 11^{\circ} 40.58^{\prime} \mathrm{W} ; 744 \mathrm{~m}$; 31 Jul. 2011; BANGAL $0711 \mathrm{~V} 4 ;$ MNCN • $1 \mathrm{v} ; 42^{\circ} 56.77^{\prime} \mathrm{N}$, $11^{\circ} 58.53^{\prime} \mathrm{W}$; $1631 \mathrm{~m}$; 2 Aug. 2011; BANGAL 0711 V5; MNCN.

\section{Remarks}

This minute species is represented both in shallow and deep samples from INDEMARES BANGAL. The illustrated syntype (Fig. 32E-F), deemed to be a holotype in Allen \& Hannah (1989), is larger, with more robust teeth, but otherwise shares with our specimens the unusual inequilateral outline with the pointed posterior part shorter than the anterior. Sizes $(3.12$ and $1.74 \mathrm{~mm}$ ) reported by Allen \& Hannah (1989) for additional specimens are in the same range. Although this may be an undescribed species similar to L. orixa, we prefer to use tentatively this name and await the availability of live-taken material for further study.

Family Yoldiidae Dall, 1908

Genus Yoldiella Verrill \& Bush, 1897

\section{Type species}

Yoldia lucida Lovén, 1846, by original designation.

Yoldiella valorousae Killeen \& J.A. Turner, 2009

Fig. 32I-J

\section{Material examined}

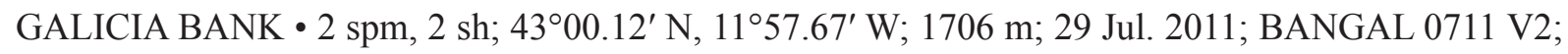
MNCN • 2 sh, $1 \mathrm{v} ; 42^{\circ} 56.77^{\prime} \mathrm{N}, 1^{\circ} 58.53^{\prime} \mathrm{W} ; 1631 \mathrm{~m} ; 2$ Aug. 2011; BANGAL $0711 \mathrm{~V} 5$; MNCN • $1 \mathrm{v} ; 42^{\circ} 41.87^{\prime} \mathrm{N}, 11^{\circ} 26.71^{\prime} \mathrm{W} ; 1720 \mathrm{~m}$; 8 Aug. 2011; BANGAL $0711 \mathrm{~V} 10 ;$ MNCN ・ $1 \mathrm{v} ; 42^{\circ} 32.16^{\prime} \mathrm{N}$, $12^{\circ} 03.79^{\prime} \mathrm{W} ; 1585 \mathrm{~m}$; 5 Aug. 2011; BANGAL 0711 DR12; MNCN.

\section{Remarks}

There is a complicated nomenclatural and taxonomic history for the small Yoldiella species originally described by Jeffreys (1876) as Leda lata, from abyssal depths of the North Atlantic. The name is a secondary homonym of Nucula lata Hinds, 1843, for which reason it was renamed Leda jeffreysi Hidalgo, 1877. Allen et al. (1995) considered that Jeffreys' type material comprised two different species; they used the preoccupied name Yoldiella lata for one of them and the replacement name Yoldiella jeffreysi for the 


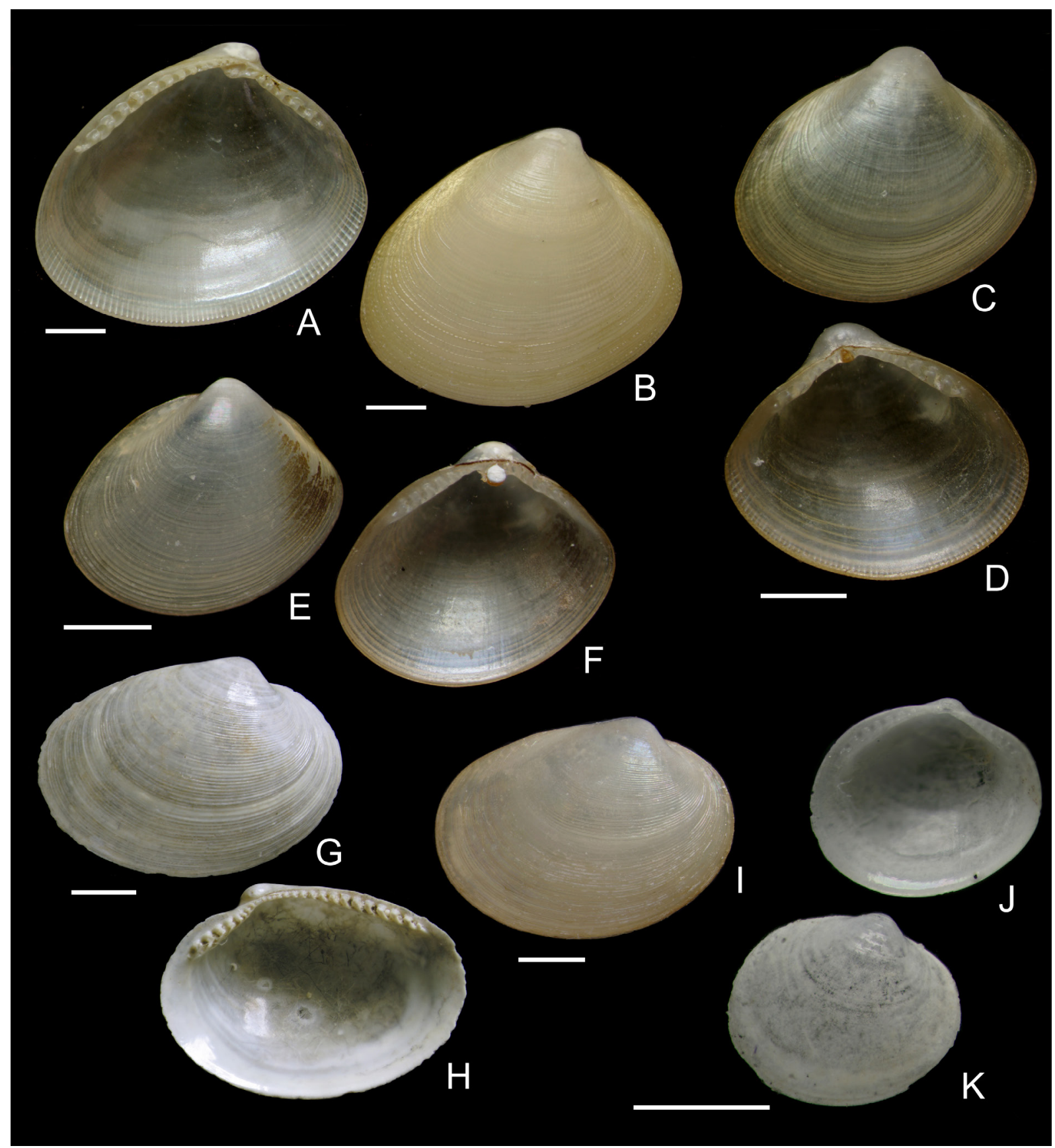

Fig. 31. Protobranchia 1. A-B. Nucula tumidula Malm, 1861, BANGAL 0711, V5, $1631 \mathrm{~m}, 5.5$ and $5.4 \mathrm{~mm}$. C-D. Nucula atacellana Schenck, 1939, BANGAL 0711, V10, $1720 \mathrm{~m}, 3.5 \mathrm{~mm}$. E-F. Ennucula corbuloides (Seguenza, 1877), BANGAL 0711, V2, 1706 m, 3.2 mm. G-H. Tindaria sericea (Jeffreys, 1876), BANGAL 0711, V2, 4.7 mm. I. Tindaria sericea, BANGAL 0711, V5, $4.5 \mathrm{~mm}$. J-K. Pristigloma minima (Seguenza, 1877), SEAMOUNT 1, DW111, 675-685 m, $1.7 \mathrm{~mm}$. Scale bars $=1 \mathrm{~mm}$. 
other one, disregarding the nomenclatural rule (ICZN Art. 72.7) which makes them objective synonyms. The nomenclatural flaw was fixed by Killeen \& Turner (2009), who endorsed the specific distinction, based Yoldiella jeffreysi on the lectotype of Y. lata (USNM 199696, from "Valorous" stn 16, west of Rockall Plateau, 1785 fms [3265 m]) designated by Allen \& Hannah (1989) for their concept of Yoldiella jeffreysi, and named Yoldiella valorousae the second species (treated as "Yoldiella lata" in Allen \& Hannah 1989), based on a shell (USNM 199695) from "Valorous" stn 9, off S Greenland, 1750 fms [3200 m]. Allen \& Hannah (1989) and Killeen \& Turner (2009) reported both species as widespread in the North Atlantic. Both species are similar in outline but $Y$. valorousae differs from $Y$. jeffreysi in being more compressed.

Family Pristiglomidae Sanders \& Allen, 1973

Genus Pristigloma Dall, 1900

\section{Type species}

Glomus nitens Jeffreys, 1876, retained from replaced name.

Pristigloma minima (Seguenza, 1877)

Fig. $31 \mathrm{~J}-\mathrm{K}$

Yoldia minima Seguenza, 1877a: 96.

Yoldia minima - Seguenza 1877b: 1178, pl. 5 figs 27, 27a-c.

Pristigloma minima (Seguenza, 1877) - Hoffman \& Freiwald 2017: 69.

\section{Material examined}

GALICIA BANK • $1 \mathrm{sh} ; 42^{\circ} 40^{\prime} \mathrm{N}, 1^{\circ} 36^{\prime} \mathrm{W} ; 675-685 \mathrm{~m}$; 19 Oct. 1987; SEAMOUNT 1 DW111; MNHN • $1 \mathrm{v} ; 43^{\circ} 00.12^{\prime} \mathrm{N}, 1^{\circ} 57.67^{\prime} \mathrm{W} ; 1706 \mathrm{~m}$; 29 Jul. 2011; BANGAL $0711 \mathrm{~V} 2$; MNCN • $2 \mathrm{v}$; $42^{\circ} 41.94^{\prime} \mathrm{N}, 11^{\circ} 40.58^{\prime} \mathrm{W}$; $744 \mathrm{~m}$; 31 Jul. 2011; BANGAL 0711 V4; MNCN.

\section{Remarks}

This minute species, originally described from the Pleistocene of Sicily (see Di Geronimo \& La Perna 1997), has been reported from the Canaries (Ortega \& Gofas 2019) and from several North Atlantic seamounts including GB (Hoffman \& Freiwald 2017). Pseudoglomus pompholyx (Dall, 1890) from the Western Atlantic is superficially very similar, but larger $(4 \mathrm{~mm})$ and differs in that the ligament is set in a pit dorsally to the hinge line which remains unaffected (see Ockelmann \& Warén 1998 for a good figure), whereas the present species has a resilifer interrupting the hinge. The generic placement could only be ascertained with live-taken specimens.

$$
\begin{gathered}
\text { Subclass Autobranchia Grobben, } 1894 \\
\text { Superorder Anomalodesmata } \\
\text { Family Lyonsiellidae Dall, } 1895
\end{gathered}
$$

Genus Policordia Dall, Bartsch \& Rehder, 1938

\section{Type species}

Policordia diomedea Dall, Bartsch \& Rehder, 1938, by original designation.

Policordia gemma (Verrill, 1880)

Fig. 39E-F

\section{Material examined}

GALICIA BANK • $6 \mathrm{v} ; 43^{\circ} 00.12^{\prime} \mathrm{N}, 11^{\circ} 57.67^{\prime} \mathrm{W}$; $1706 \mathrm{~m}$; 29 Jul. 2011; BANGAL $0711 \mathrm{~V} 2$; MNCN • $2 \mathrm{v} ; 4^{\circ} 56.77^{\prime} \mathrm{N}, 1^{\circ} 58.53^{\prime} \mathrm{W}$; $1631 \mathrm{~m} ; 2$ Aug. 2011; BANGAL $0711 \mathrm{~V} 5 ; \mathrm{MNCN} \bullet 2 \mathrm{spm} ; 42^{\circ} 38.48^{\prime} \mathrm{N}$, 


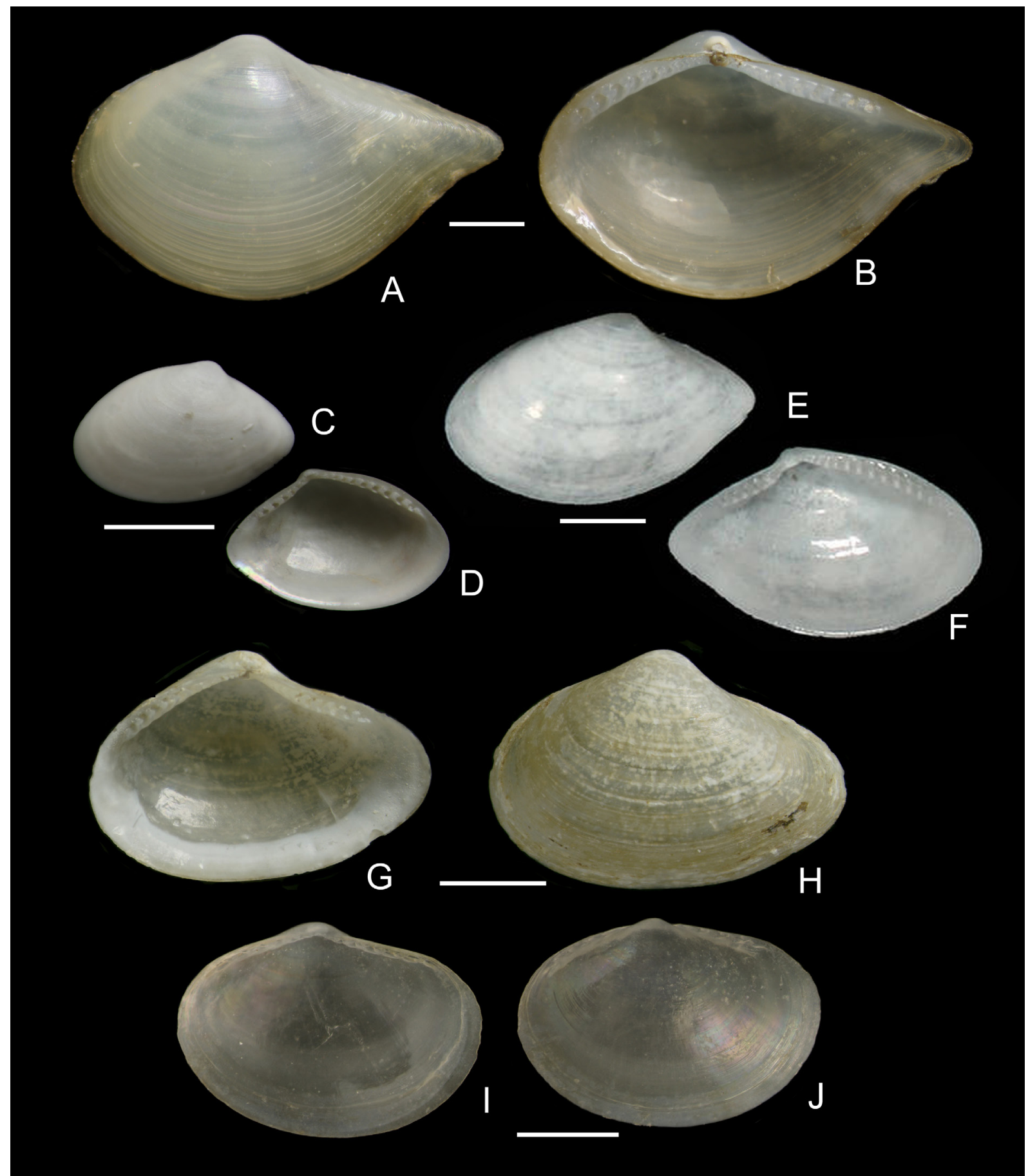

Fig. 32. Protobranchia 2. A-B. Ledella messanensis (Jeffreys, 1870), BANGAL 0711, V10, $1720 \mathrm{~m}$, $5.8 \mathrm{~mm}$. C-D. Ledella cf. orixa (Dall, 1927), BANGAL 0711, V5, $1631 \mathrm{~m}, 2.0 \mathrm{~mm}$. E-F. Syntype (USNM 108190) of Leda orixa Dall, 1927, off Georgia $30.975^{\circ} \mathrm{N}, 79.6417^{\circ} \mathrm{W}, 538 \mathrm{~m}, \mathrm{R} / \mathrm{V}$ Albatross, $3.6 \mathrm{~mm}$ (photograph by Ellen Strong, reproduced with the permission of the National Museum of Natural History, Smithsonian Institution, $10^{\text {th }}$ and Constitution Ave. N.W., Washington, DC 20560-0193 http://www.nmnh.si.edu/). G-H. Yoldiella semistriata (Jeffreys, 1879), BANGAL 0711, V2, 1706 m, $3.2 \mathrm{~mm}$. I-J. Yoldiella valorousae Killeen \& J.A. Turner, 2009, BANGAL 0711, V2, 1706 m, 3.0 mm. Scale bars $=1 \mathrm{~mm}$. 


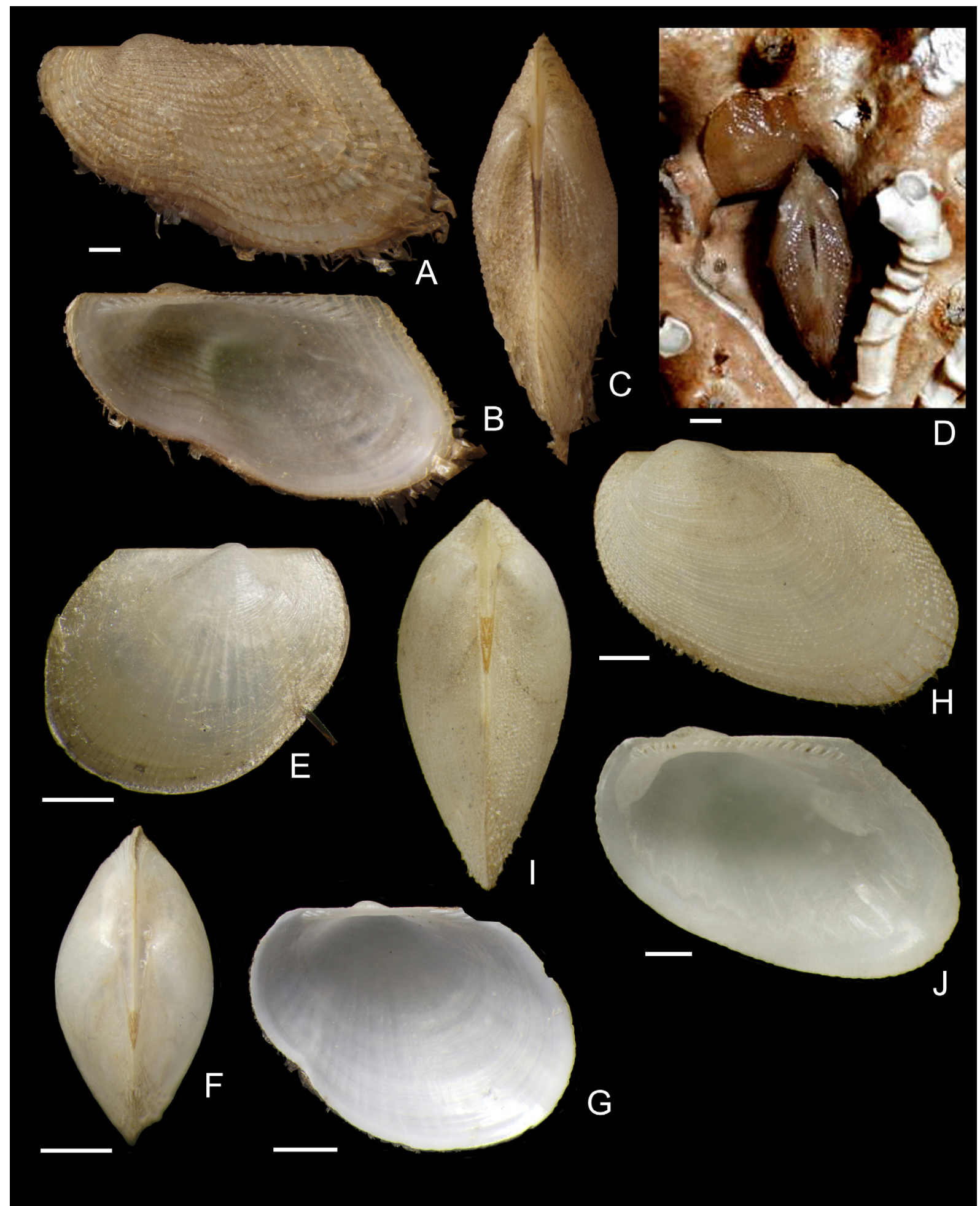

Fig. 33. Arcidae. A-C. Asperarca nodulosa (Müller, 1776), BANGAL 0711, DR14, $1130 \mathrm{~m}, 13.3 \mathrm{~mm}$. D. A. nodulosa among dead coral branches, BANGAL 0711, GOC6, $903 \mathrm{~m}$. E-G. Bathyarca pectunculoides (Scacchi, 1835), SEAMOUNT 1, DW 108, 1110-1125 m, $4.3 \mathrm{~mm}, 4.4 \mathrm{~mm}$ and $5.1 \mathrm{~mm}$. H-J. Bathyarca philippiana (Nyst, 1848), SEAMOUNT 1, DW111, 675-685 m, 7.2 and $7.9 \mathrm{~mm}$. Scale bars $=1 \mathrm{~mm}$. 


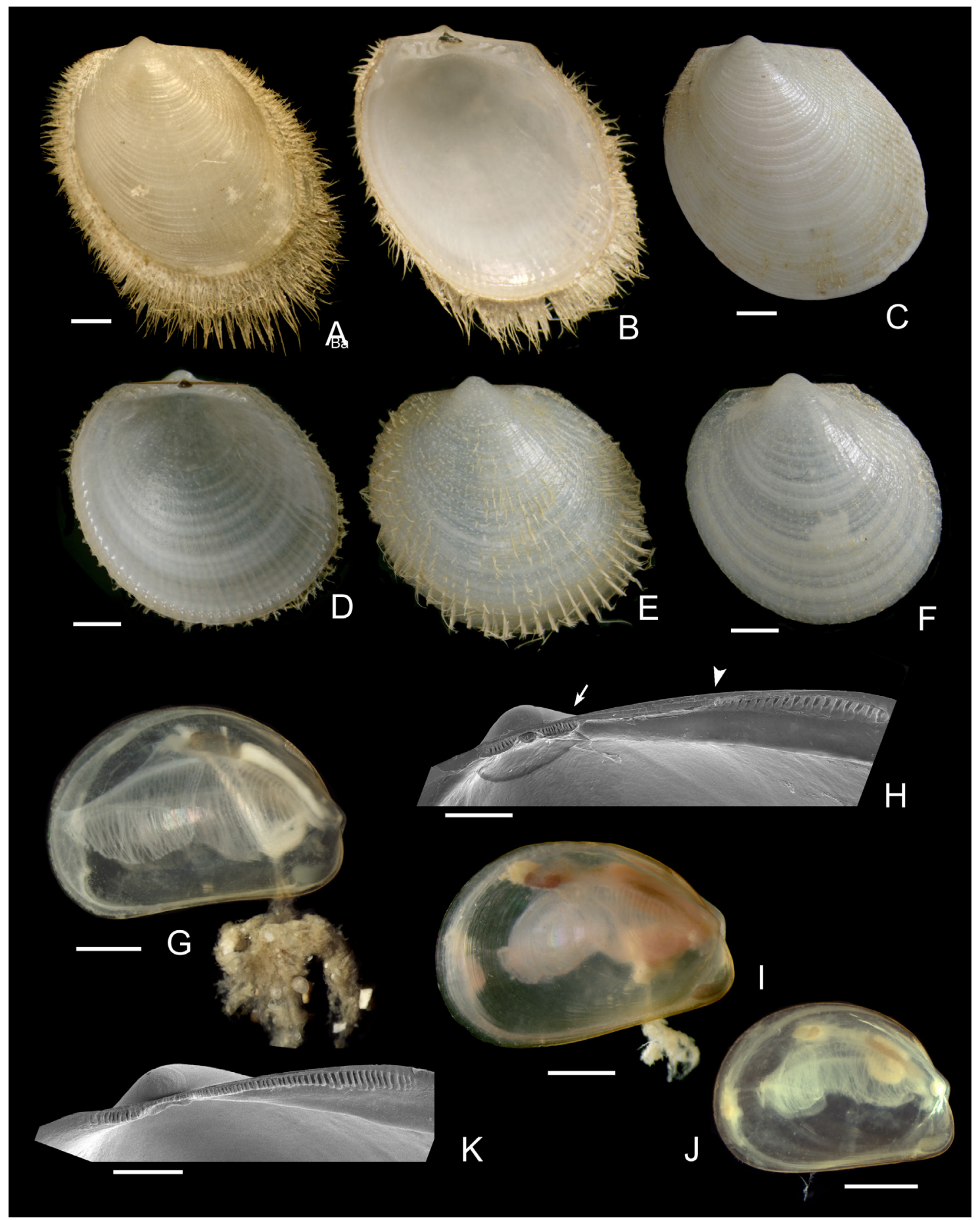

Fig. 34. Limopsidae and Mytilidae. A-B. Limopsis minuta (Philippi, 1836), ECOMARG 0709 V4, $744 \mathrm{~m}$, height $7.8 \mathrm{~mm}$. C. Limopsis minuta, valve without periostracum, same locality, $6.7 \mathrm{~mm}$. D-E. Limopsis cristata Jeffreys, 1876, BANGAL 0711, V10, $1720 \mathrm{~m}$, height $5.6 \mathrm{~mm}$. F. Limopsis cristata, valve without periostracum, BANGAL 0711, V5, $1631 \mathrm{~m}, 5.3 \mathrm{~mm}$. G. Dacrydium wareni Salas \& Gofas, 1997, BANGAL 0711, V6, $903 \mathrm{~m}, 4.5 \mathrm{~mm}$. H. D. wareni, SEM micrograph of the hinge of a right valve; arrow points to the posterior end of the first (embryonic) set of teeth, arrowhead to the beginning of the second set. I-J. D. ockelmanni Mattson \& Warén, 1977, BANGAL 0711, V10, 4.4 and $3.3 \mathrm{~mm}$. K. D. ockelmanni, SEM micrograph of the hinge of a right valve showing the continuous set of teeth. Scale bars: A-G, I-J = 1mm; H, K = $200 \mu \mathrm{m}$. 


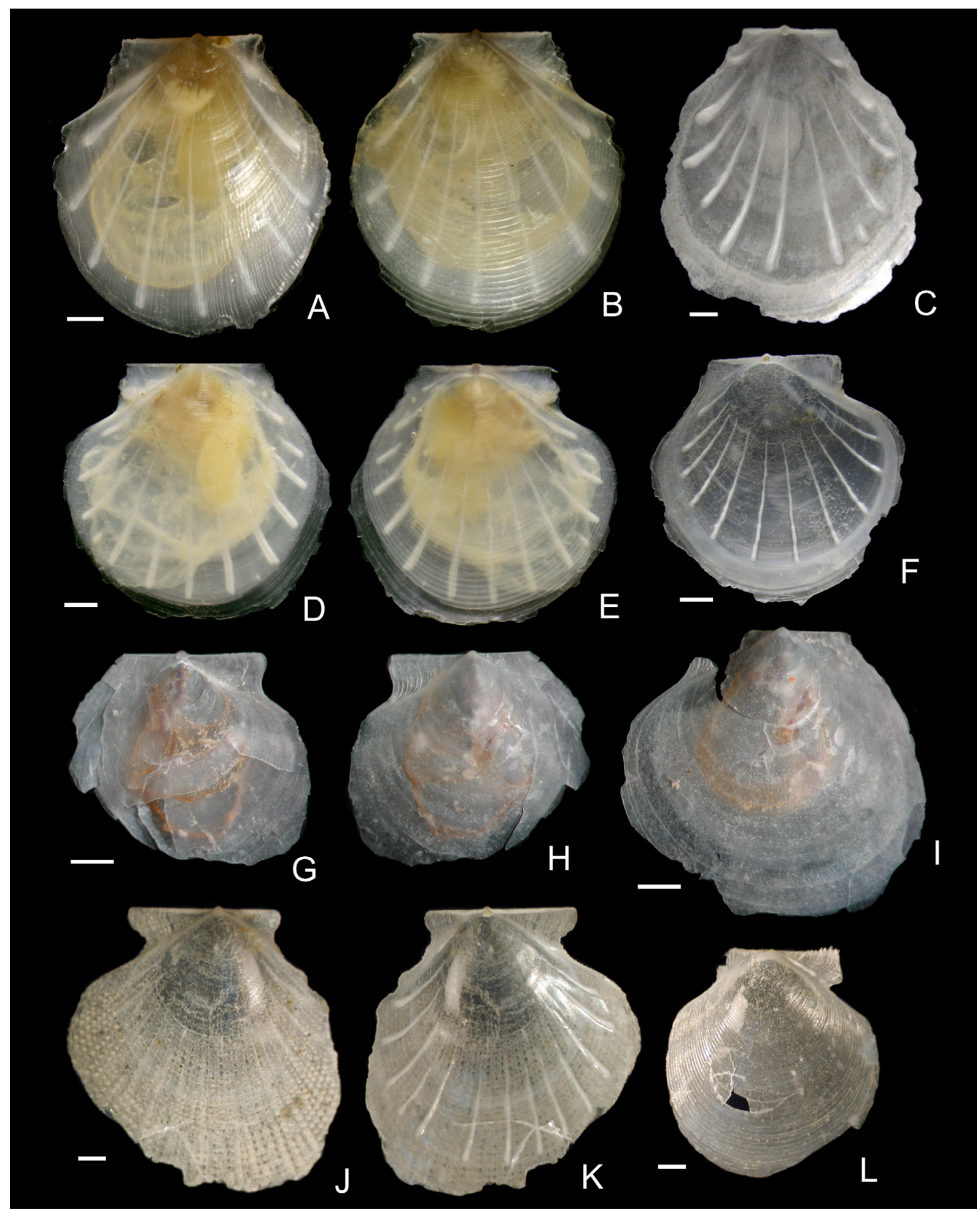

Fig. 35. Propeamussiidae. A-B. Propeamussium lucidum (Jeffreys in Wywille-Thomson, 1873), BANGAL 0711, V8, $1565 \mathrm{~m}, 8.2 \mathrm{~mm}$. C. P. lucidum, BANGAL 0711, V7, $1462 \mathrm{~m}, 10.5 \mathrm{~mm}$. D-F. Parvamussium propinquum (E.A. Smith, 1885), BANGAL 0711, V10, $1720 \mathrm{~m}$, height $7.8 \mathrm{~mm}$ and $7.5 \mathrm{~mm}$. G-I. Catillopecten eucymatus (Dall, 1898), SEAMOUNT 1, DW108, 1110-1125 m, 5.0 and $6.7 \mathrm{~mm}$. J-K. Cyclopecten antiquatus (Philippi, 1844), SEAMOUNT 1, DW116, 985-1000 m, right valve, $10.2 \mathrm{~mm}$. L. C. antiquatus, left valve, SEAMOUNT 1, DW108, $8.0 \mathrm{~mm}$. Scale bars $=1 \mathrm{~mm}$. 


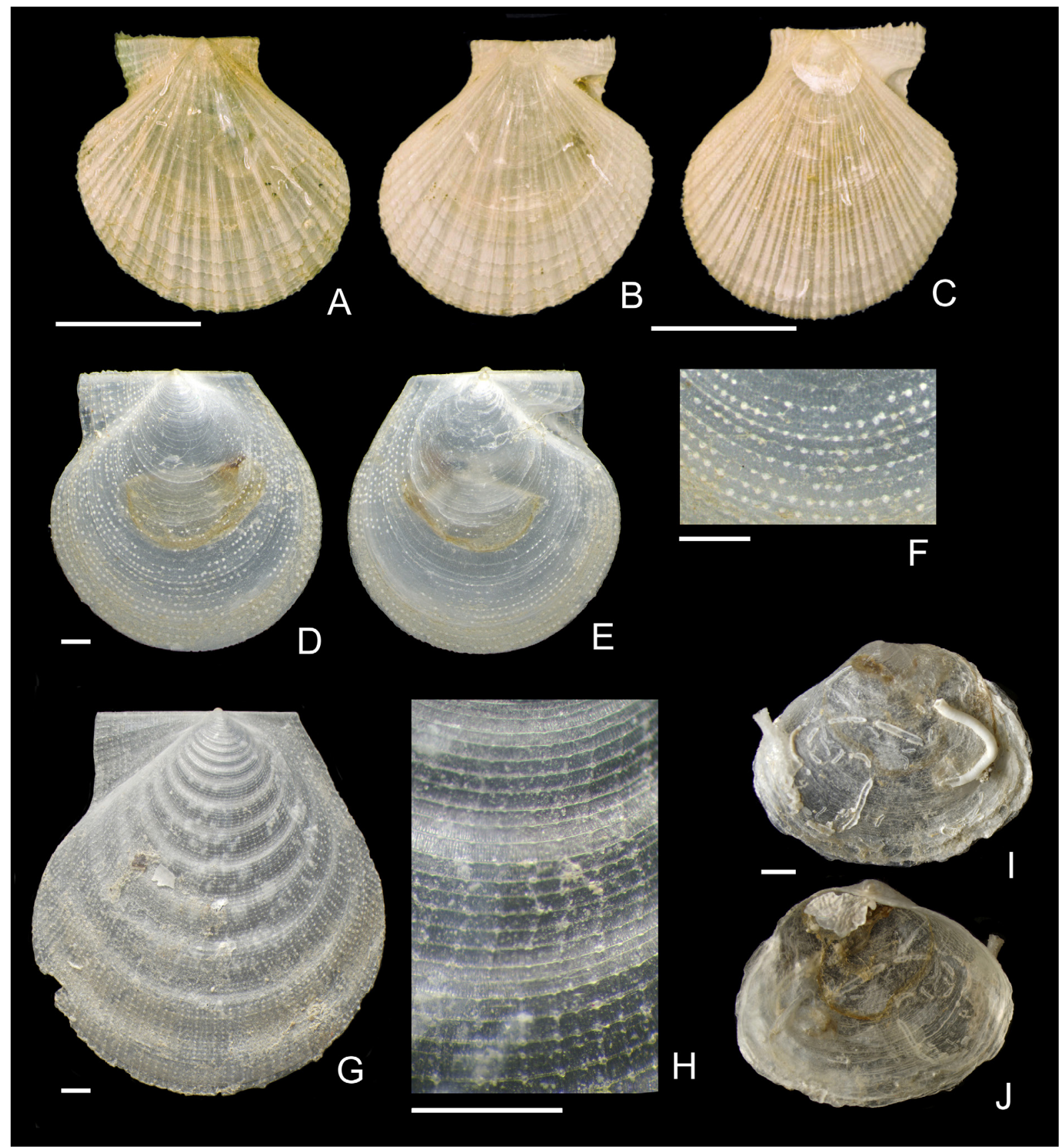

Fig. 36. Pectinidae, Anomiidae. A-C. Pseudamussium sulcatum (Müller, 1776), SEAMOUNT 1, DW116, 985-1000 m, 19.1 and $20.1 \mathrm{~mm}$. D-F. Delectopecten vitreus (Gmelin, 1791), BANGAL 0711, GOC3, $785 \mathrm{~m}, 9.5 \mathrm{~mm}$, and detail of the sculpture of the right valve. G-H. Hyalopecten pudicus (E.A. Smith, 1885), right valve, BANGAL 0711, DR15, $1410 \mathrm{~m}$, height $13.2 \mathrm{~mm}$, and detail of the sculpture. I-J. Heteranomia squamula (Linnaeus, 1758), SEAMOUNT 1, DW106, 765 m, $8.0 \mathrm{~mm}$. Scale bars: A-C $=10 \mathrm{~mm}$; D- $\mathrm{J}=1 \mathrm{~mm}$. 


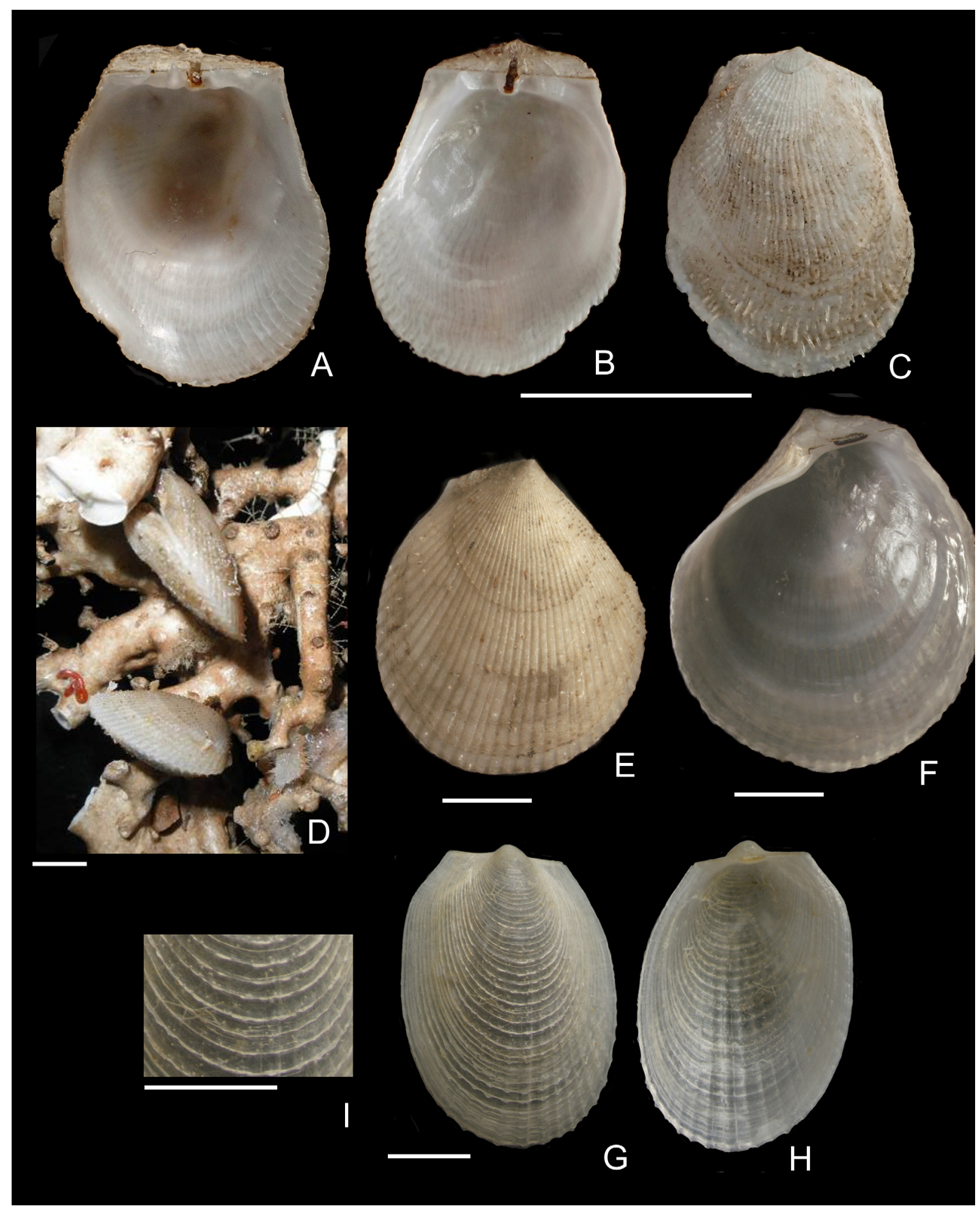

Fig. 37. Limidae, Spondylidae. A-C. Spondylus gussonii Costa, 1830, ECOMARG 0709, V5, 876 m, $14.5 \mathrm{~mm}$. D. Lima marioni P. Fischer, 1882, among dead coral branches, BANGAL 0711, GOC6, 903 m. E-F. L. marioni, ECOMARG 0709, V5, $876 \mathrm{~m}, 35.5$ and $41 \mathrm{~mm}$. G-H. Limatula laminifera (E.A. Smith, 1885), BANGAL 0711, V2, $1706 \mathrm{~m}$, height $3.6 \mathrm{~mm}$. I. Same specimen, detail of the sculpture. Scale bars: A-F $=10 \mathrm{~mm} ; \mathrm{G}-\mathrm{I}=1 \mathrm{~mm}$. 


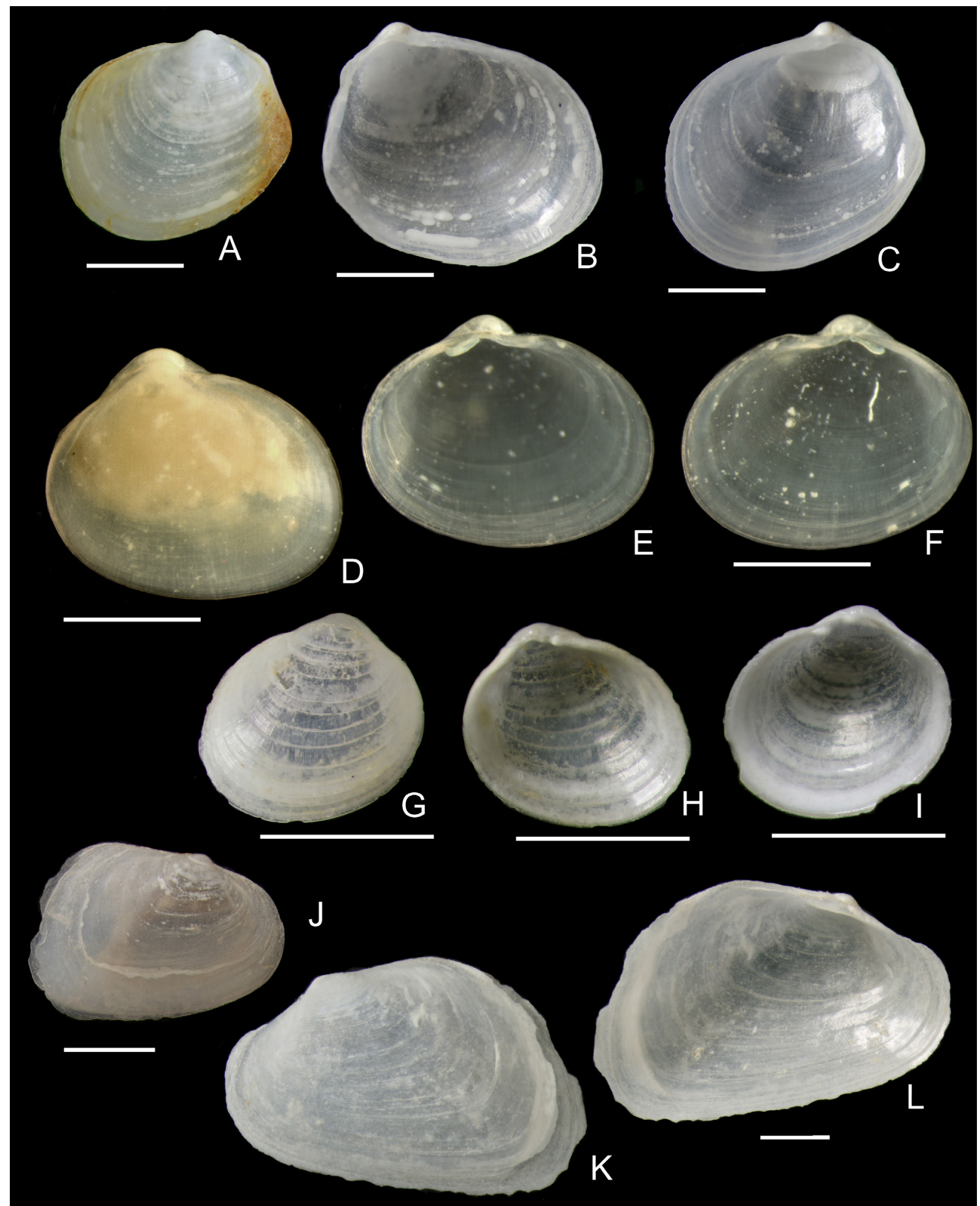

Fig. 38. Thyasiridae, Lasaeidae, Basterotiidae. A-C. Thyasira succisa (Jeffreys, 1876), SEAMOUNT 1, DW108, 1110-1125 m, 2.4, 2.9 and $2.7 \mathrm{~mm}$. D-F. Syssitomya pourtalesiana Oliver, 2012, BANGAL 0711, V5, $1631 \mathrm{~m}, 2.2 \mathrm{~mm}$. G-I. Draculamya porobranchiata Oliver \& Lützen, 2011, BANGAL 0711, V4, 744 m, 1.3 mm. J-L. Atopomya dolobrata Oliver, 2013, SEAMOUNT 1, DW116, 985-1000 m, 2.8 and $5.2 \mathrm{~mm}$. Scale bars $=1 \mathrm{~mm}$. 


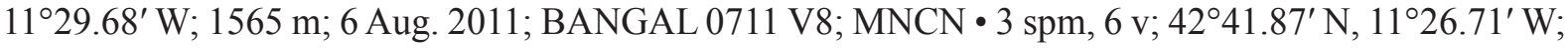
1720 m; 8 Aug. 2011; BANGAL 0711 V10; MNCN.

\section{Remarks}

Most of the specimens collected during BANGAL 0711 were assigned to Policordia gemma as represented on Fig. 39E-F. Nevertheless, a second species, represented by only three specimens and one shell, was present in sample V10 $(1720 \mathrm{~m})$ together with $P$. gemma and was tentatively identified in the preliminary INDEMARES BANGAL 0711 report (Gofas et al. 2014b) and in Gofas et al. (2017) as Policordia atlantica Allen \& J.F. Turner, 1974.

\section{Policordia sp.}

Fig. 39G

\section{Material examined}

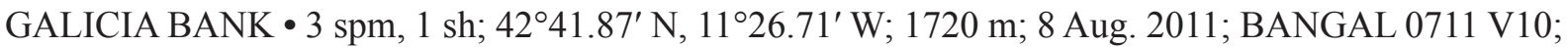
MNCN.

\section{Remarks}

This second species differs in being less inflated and having an outline with a more produced posterior end, resulting in that the shell is longer than high (higher than long in P. gemma). Whereas our specimens agree in shape and size with the specimens from the Porcupine Sea Bight (1630-1640 m) illustrated on the NMW website (Oliver et al. 2016), we are reluctant to confirm this identification taking into account the taxonomic uncertainty surrounding $P$. atlantica.

Families Cuspidariidae Dall, 1886, Halonymphidae Scarlato \& Starobogatov, 1983 and Protocuspidariidae Scarlato \& Starobogatov, 1983

\section{Key to genera and species of the superfamily Cuspidarioidea found on GB}

1. Sculpture with definite radial ribs

- Sculpture only commarginal (may include faint ridges from umbo to posterior part), or surface of shell smooth

2. Two strong radial ribs on posterior half, anterior with commarginal undulations

Myonera paucistriata Dall, 1886 (Fig. 41 A-C)

- Numerous fine radial ribs on posterior half ......Cardiomya cadiziana M. Huber, 2010 (Fig. 41G-I)

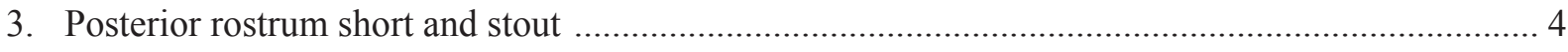

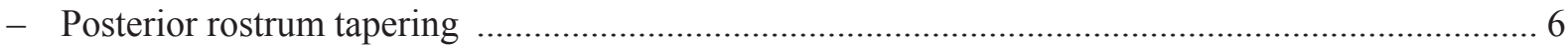

4. Shell inflated, smooth and glossy ................ Jeffreysomya truncata (Jeffreys, 1882) (Fig. 41D-F)

- Shell compressed, with marked growth lines and wrinkles on posterior part .................................. 5

5. An anterior lateral tooth on the right valve .Protocuspidaria verityi Allen \& Morgan, 1981 (Fig. 43 D-G)

- No teeth on either valve ................... Protocuspidaria simplis Allen \& Morgan, 1981 (Fig. 43 H-K)

6. Hinge of right valve with a small knob-like cardinal and no lateral teeth; posterior rostrum pointed, not definitely distinct from rest of the shell ....Halonympha depressa (Jeffreys, 1882) (Fig. 43 A-C)

- Hinge of right valve with at least one (posterior) lateral tooth 
7. Hinge of right valve with anterior and posterior lateral teeth (genus Rhinoclama) ........................ 8

- Hinge of right valve with only a posterior lateral tooth

Cuspidaria cf. rostrata (Spengler, 1793) (Fig. 42G-I)

8. Posterior part of shell (excluding rostrum) with widely spaced commarginal cordlets; anterior lateral long and lamellar Rhinoclama semistrigosa (Jeffreys, 1882) (Fig. 42D-F)

- Posterior part of shell (excluding rostrum) with growth lines only; anterior lateral short and bulging Rhinoclama teres (Jeffreys, 1882) (Fig. 42A-C)

Genus Cuspidaria Nardo, 1840

\section{Type species}

Cuspidaria typus Nardo, 1840 = Cuspidaria cuspidata (Olivi, 1792), by monotypy.

\section{Cuspidaria cf. rostrata (Spengler, 1793)}

Fig. 42G-I

\section{Material examined}

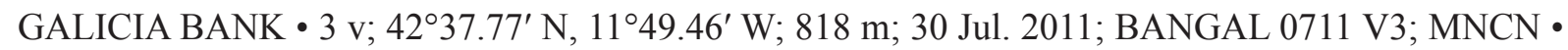

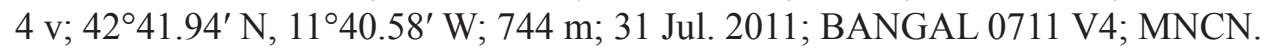

\section{Remarks}

A specimen of this species from GB was figured by Rolán et al. (1990) as Cuspidaria capensis (E.A. Smith, 1885). Specimens from GB have a posterior rostrum shorter than usually seen in Cuspidaria rostrata, and are smaller, resembling in those features Cuspidaria meteoris Krylova, 2006, described from the mid-Atlantic seamount group. However, they do not show the sloping postero-ventral margin characteristic of the latter, and are therefore conservatively identified to the mainland species.

\section{Genus Myonera Dall \& E.A. Smith, 1886}

\section{Type species}

Myonera paucistriata Dall, 1886, by original designation.

Myonera paucistriata Dall, 1886

Fig. $41 \mathrm{~A}-\mathrm{C}$

\section{Material examined}

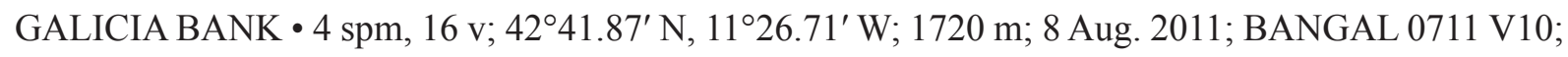
MNCN.

\section{Remarks}

This species was mistaken in the preliminary INDEMARES BANGAL 0711 report (Gofas et al. 2014b), for the similar M. angularis (Jeffreys, 1876) which has been reported from off Portugal (type locality) and off northwestern Morocco (Salas 1996: fig. 127) but not in Spain. The latter differs in having only one sharp keel delimiting the smooth posterior area and in having more numerous and finer commarginal ridges on the anterior and median part of the shell. Myonera acutecarinata (Dautzenberg \& H. Fischer, 1906), described from off the Cape Verde Islands, is also very similar but more tapering posteriorly. Myonera bicarinata E.A. Smith, 1896 and Myonera dispar (Dall, Bartsch \& Rehder, 1938) have been synonymized by Allen \& Morgan (1981) but cautiously retained as separate species by Huber (2010), taking into account their type localities in the Indian Ocean and off Hawaii, respectively. 


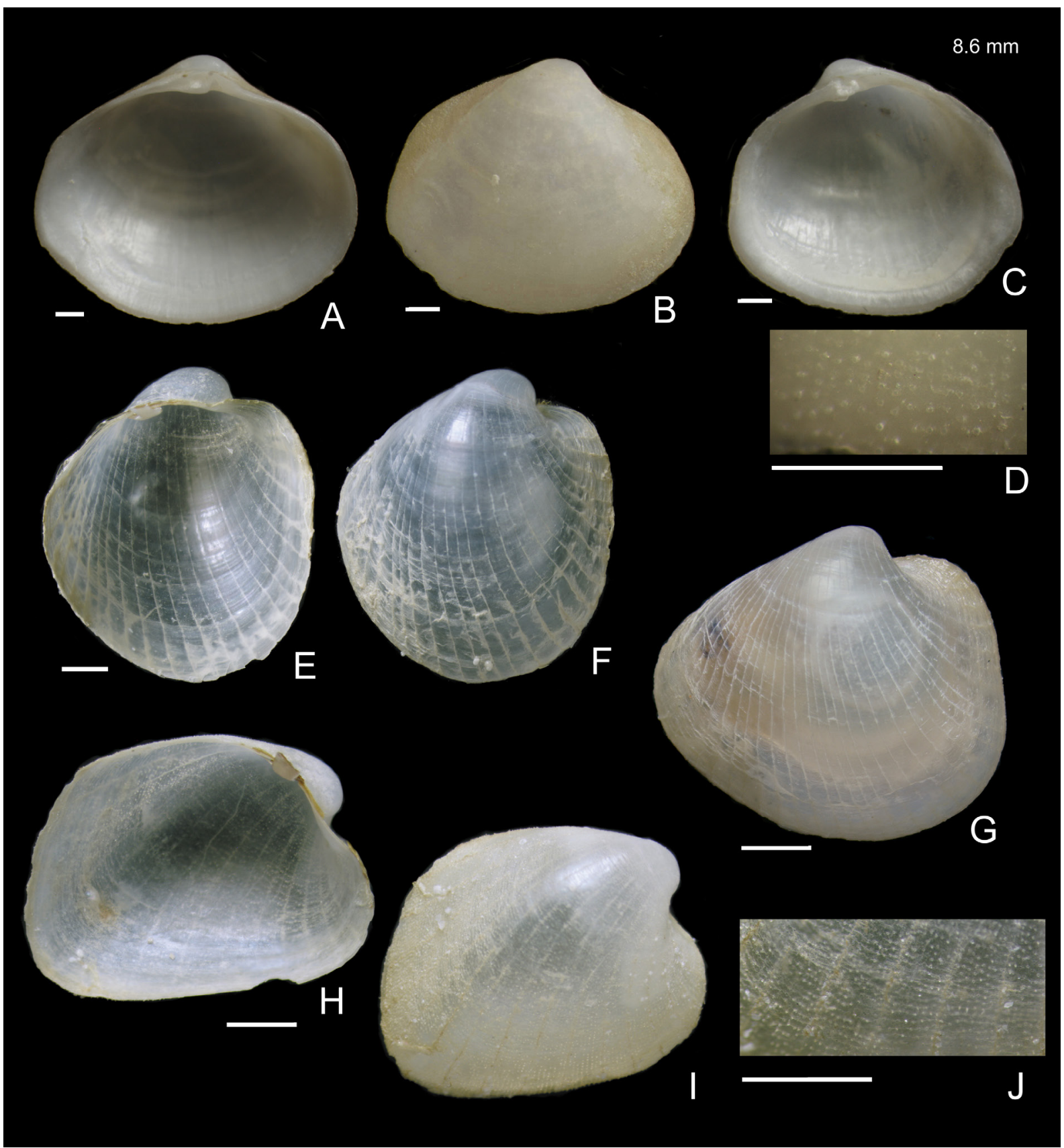

Fig. 39. Poromyidae, Lyonsiellidae. A-D. Poromya granulata (Nyst \& Westendorp, 1839), SEAMOUNT 1, DW106, $765 \mathrm{~m}, 11.3 \mathrm{~mm}, 9.0 \mathrm{~mm}$ and $8.6 \mathrm{~mm}$, and detail of the sculpture. E-F. Policordia gemma (Verrill, 1880), BANGAL 0711, V10, $1720 \mathrm{~m}$, height $6.8 \mathrm{~mm}$. G. Policordia sp., BANGAL 0711, V10, $1720 \mathrm{~m}$, length $5.0 \mathrm{~mm}$. H-J. Lyonsiella abyssicola (G.O. Sars, 1872), BANGAL 0711, V5, $1631 \mathrm{~m}, 5.0 \mathrm{~mm}$, and detail of the sculpture. Scale bars $=1 \mathrm{~mm}$. 


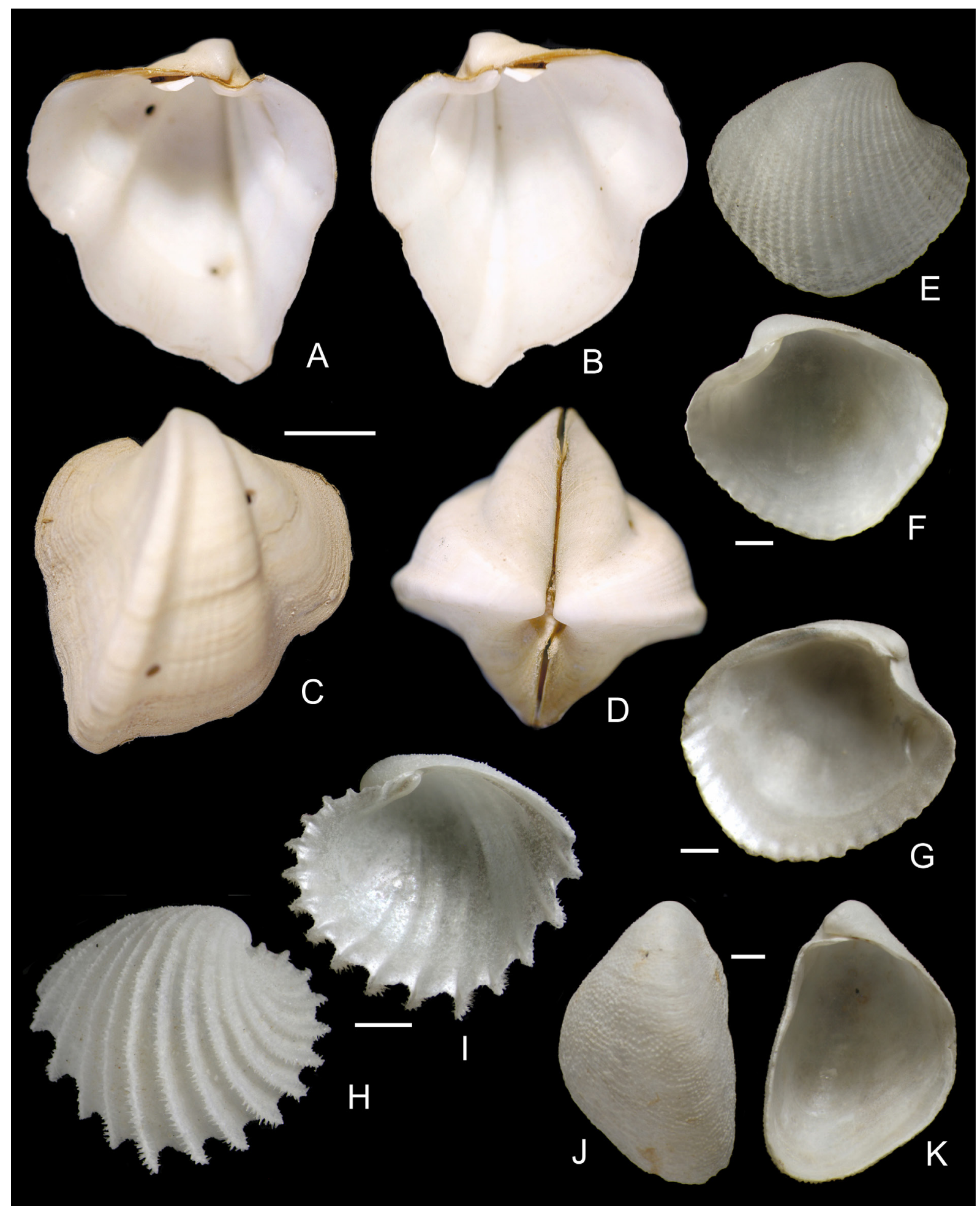

Fig. 40. Verticordiidae. A-D. Halicardia flexuosa Verrill \& S. Smith, 1881, BANGAL 0711, V10, 1720 m, $38 \mathrm{~mm}$. E-G. Haliris granulata (Seguenza, 1860), SEAMOUNT 1, DW106, $765 \mathrm{~m}, 6.9$ and $7.3 \mathrm{~mm}$. H-I. Spinosipella acuticostata (Philippi, 1844), BANGAL 0711, V3, 818 m, 5.0 mm. J-K. Halicardia angulata (Jeffreys, 1882), BANGAL 0711, V3, $818 \mathrm{~m}$, height $8.6 \mathrm{~mm}$. Scale bars: A-D = $10 \mathrm{~mm}$; E-K = $1 \mathrm{~mm}$. 


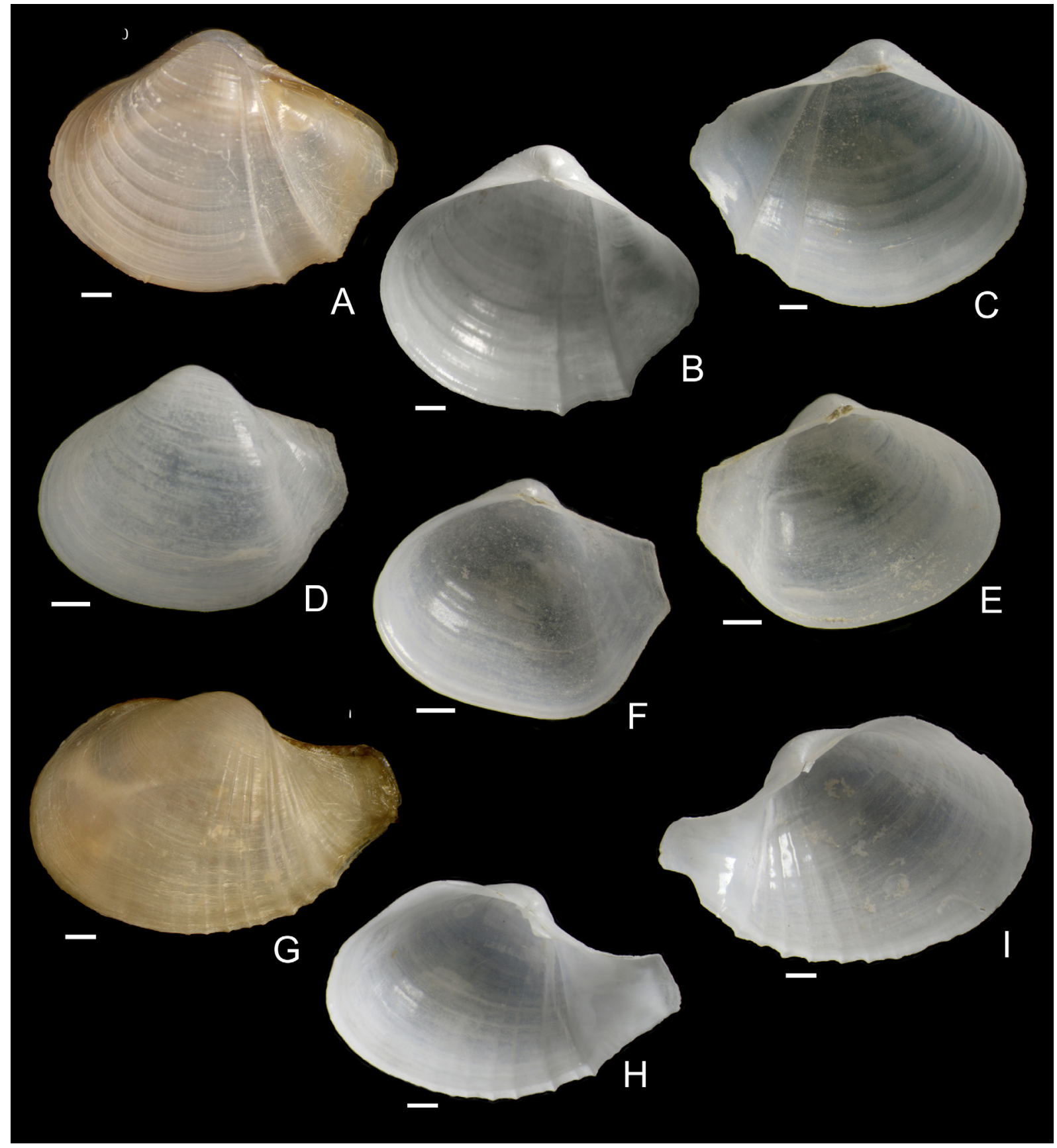

Fig. 41. Cuspidariidae. A-C. Myonera paucistriata Dall, 1886, BANGAL 0711, V10, 1720 m, 11.6 mm, $10.5 \mathrm{~mm}$ and $12.2 \mathrm{~mm}$. D-F. Jeffreysomya truncata (Jeffreys, 1882), BANGAL 0711, V4, $744 \mathrm{~m}$, $7.9 \mathrm{~mm}$ and $7.5 \mathrm{~mm}$. G-I. Cardiomya cadiziana Huber, 2010, BANGAL 0711, V6, $909 \mathrm{~m}, 12.0 \mathrm{~mm}$, $11.6 \mathrm{~mm}$ and $12.2 \mathrm{~mm}$. Scale bars $=1 \mathrm{~mm}$. 


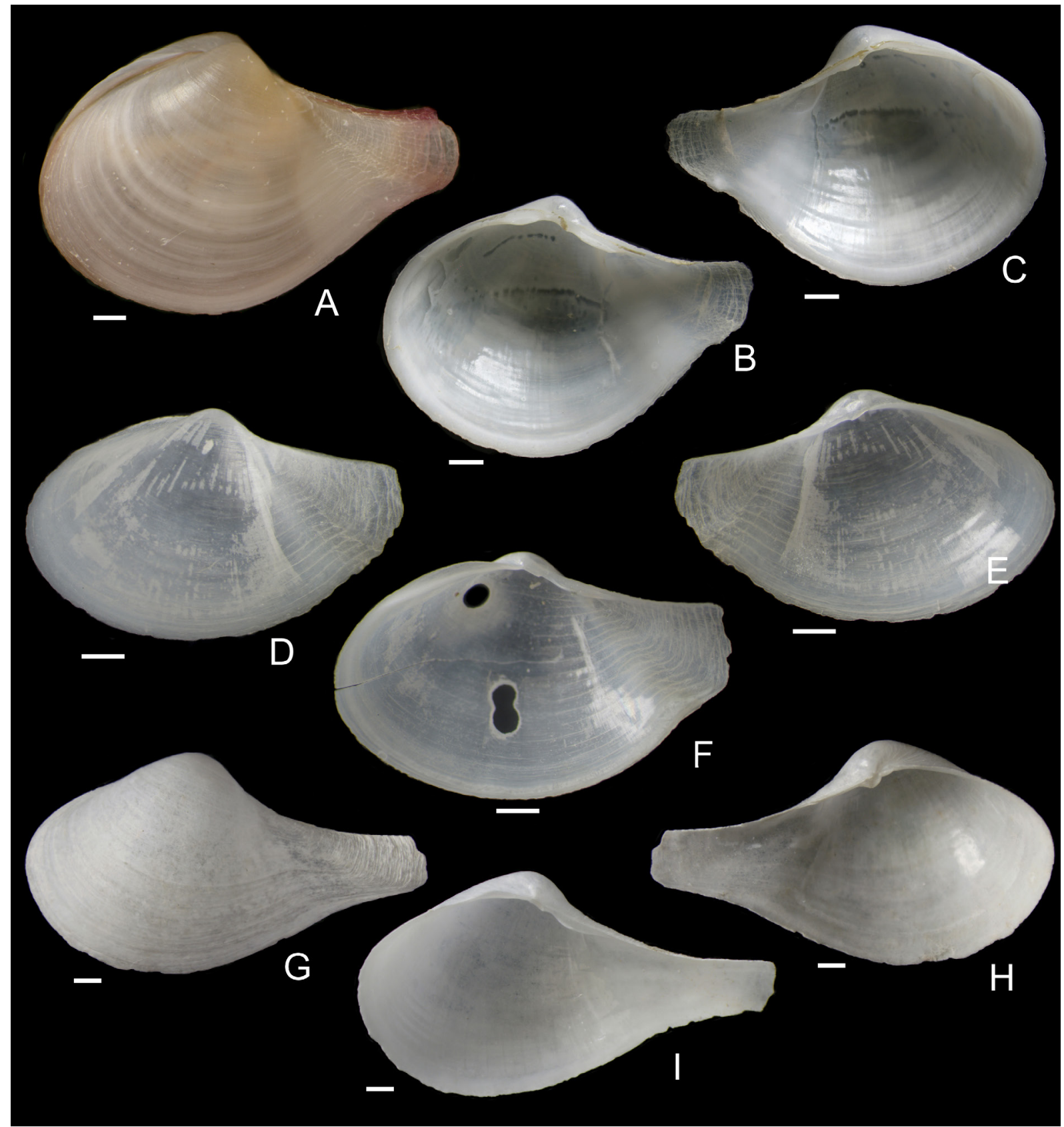

Fig. 42. Cuspidariidae. A-C. Rhinoclama teres (Jeffreys, 1882), BANGAL 0711, V5, $1631 \mathrm{~m}, 12.8 \mathrm{~mm}$ and $10.6 \mathrm{~mm}$. D-F. Rhinoclama semistrigosa (Jeffreys, 1882), BANGAL 0711, V7, $1462 \mathrm{~m}, 9.1$ and $8.7 \mathrm{~mm}$. G-I. Cuspidaria cf. rostrata (Spengler, 1793), BANGAL 0711, V3, $818 \mathrm{~m}, 14.6$ and $15.2 \mathrm{~mm}$. Scale bars $=1 \mathrm{~mm}$. 


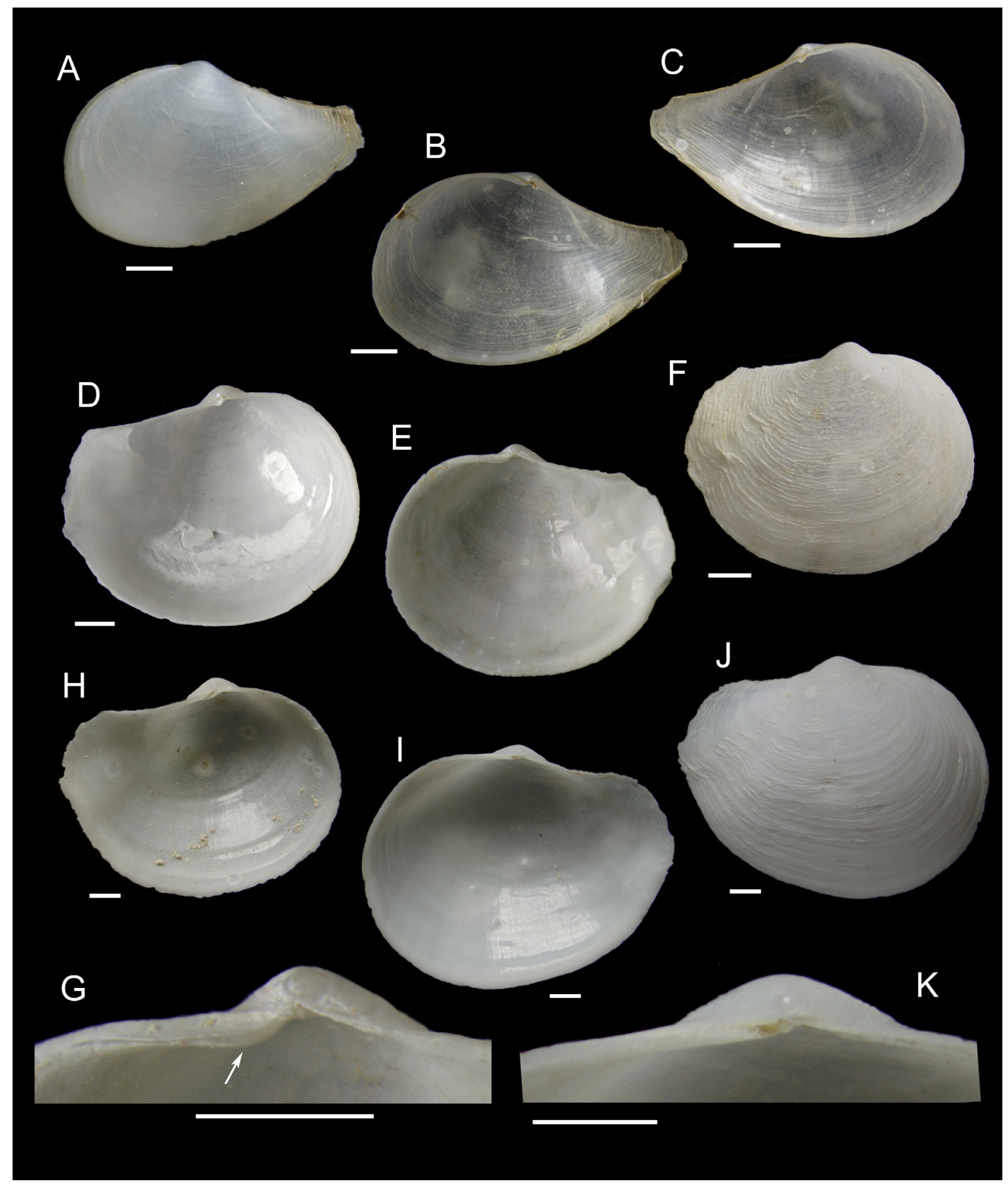

Fig. 43. Halonymphidae, Protocuspidariidae. A-C. Halonympha depressa (Jeffreys, 1882), BANGAL 0711, V2, 1706 m, 6.5 and 6.8 mm. D-F. Protocuspidaria verityi Allen \& Morgan, 1981, BANGAL 0711, V2, 7.3 and $6.4 \mathrm{~mm}$. G. Detail of the hinge of the right valve (same as E), the arrow points to the diagnostic anterior tooth. H-J. Protocuspidaria simplis Allen \& Morgan, 1981, BANGAL 0711, V10, $1720 \mathrm{~m}, 9.0 \mathrm{~mm}, 10.1 \mathrm{~mm}$. K. Detail of the hinge of the right valve (same as I), without tooth. Scale bars $=1 \mathrm{~mm}$. 


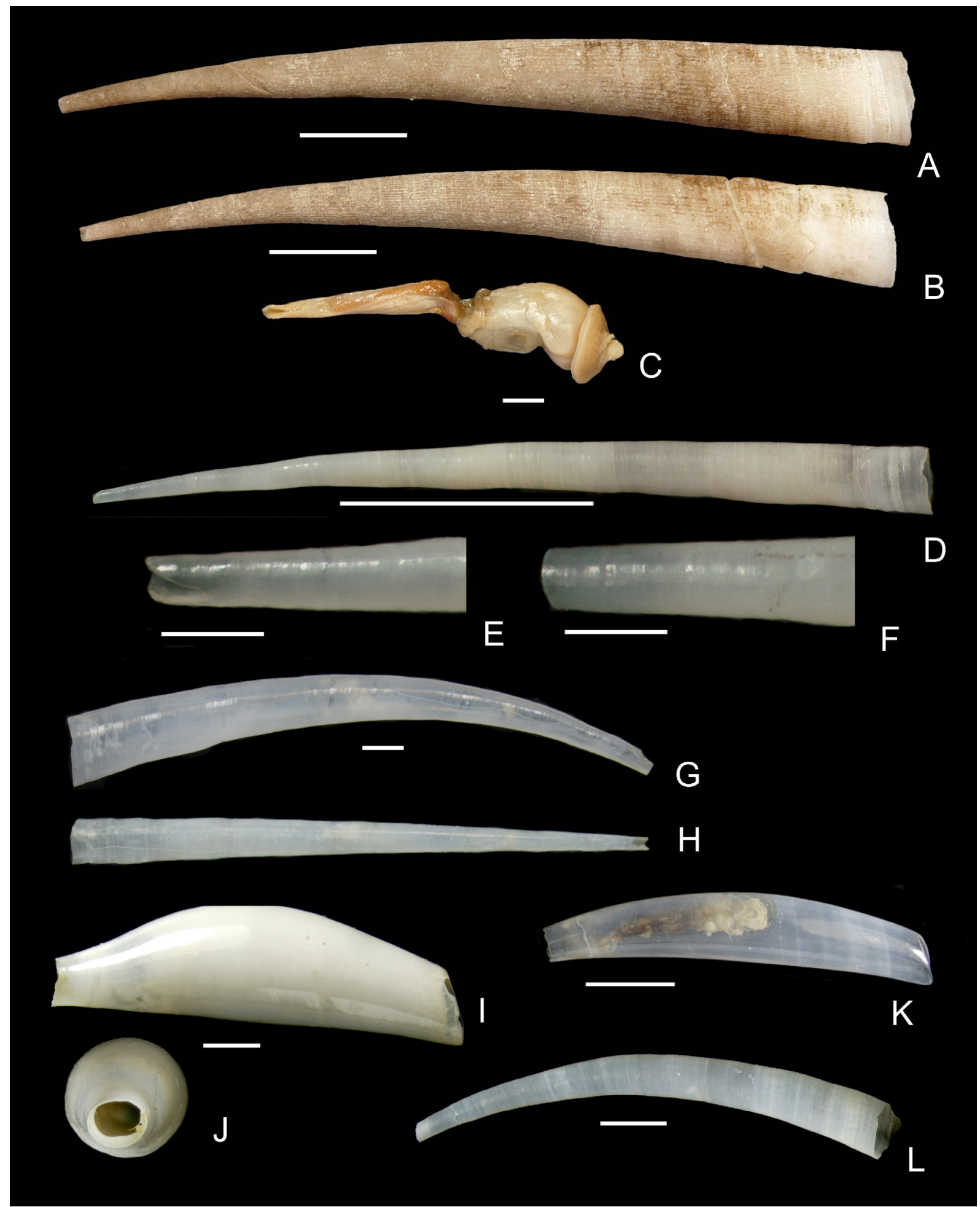

Fig. 44. Scaphopoda. A-C. Fissidentalium capillosum (Jeffreys, 1877), shell and soft parts, BANGAL 0711, V2, $1706 \mathrm{~m}$, shells 80 and $74 \mathrm{~mm}$. D-F. Antalis agilis (M. Sars in G.O. Sars, 1872), ECOMARG 0709, V5, $876 \mathrm{~m}, 32.8 \mathrm{~mm}$ and details of the posterior end. G-H. Bathoxiphus ensiculus (Jeffreys, 1877), BANGAL 0711, V5, 1631 m, 14.0 mm. I-J. Cadulus monterosatoi Locard, 1897, BANGAL 0711, V9, $1671 \mathrm{~m}, 7.2 \mathrm{~mm}$. K. Cadulus artatus Locard, 1897. BANGAL 0711, V2, $4.3 \mathrm{~mm}$. L. Pulsellum lofotense (M. Sars, 1865), BANGAL 0711, V2, $7.1 \mathrm{~mm}$. Scale bars: A-D = $10 \mathrm{~mm}$; E-L = $1 \mathrm{~mm}$. 
Family Protocuspidariidae Scarlato \& Starobogatov, 1983

Genus Protocuspidaria Allen \& Morgan, 1981

\section{Type species}

Protocuspidaria verityi Allen \& Morgan, 1981, by monotypy.

\section{Protocuspidaria verityi Allen \& Morgan, 1981}

Fig. 43D-G

\section{Material examined}

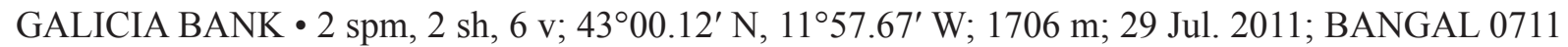
V2; MNCN • 3 v; 42 ${ }^{\circ} 37.77^{\prime} \mathrm{N}, 11^{\circ} 49.46^{\prime} \mathrm{W} ; 818 \mathrm{~m}$; $30 \mathrm{Jul}$. 2011; BANGAL $0711 \mathrm{~V} 3$; MNCN • $1 \mathrm{v}$; $42^{\circ} 59.61^{\prime} \mathrm{N}, 11^{\circ} 58.41^{\prime} \mathrm{W} ; 1671 \mathrm{~m}$; 7 Aug. 2011; BANGAL 0711 V9; MNCN.

\section{Remarks}

This species was misidentified as Protocuspidaria colpodes (Dautzenberg \& H. Fischer, 1897) in Salas (1996), in the preliminary INDEMARES BANGAL report (Gofas et al. 2014b) and in Gofas et al. (2017), on the grounds that could be an older name, but Krylova (1995) convincingly recognized these as separate species and the GB specimens would then go to $P$. verityi.

\section{Bathymetric distribution of the species}

There is a clearcut separation between mollusc communities on the shallower summit platform of GB and the deeper samples collected below the Mediterranean outflow (i.e., below $1200 \mathrm{~m}$ ). This is highly supported when involving the beam-trawl catches only (Fig. 45B) by the Bray-Curtis similarity index and a R ANOSIM value of 0.7 (both on quantitative and on presence/absence data). The grouping of the deep samples is also retrieved when taking into account all samples (Fig. 45A), even though the sampled
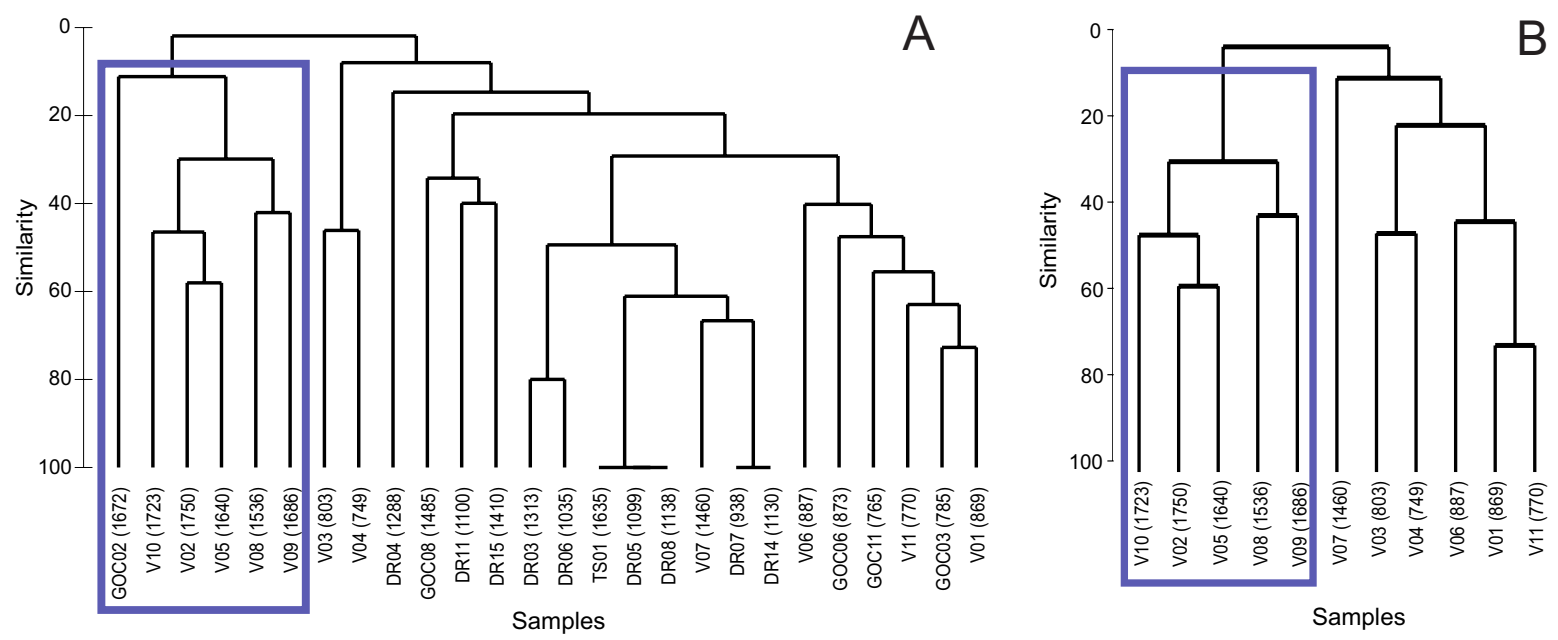

Fig. 45. Similarity between samples from the BANGAL 0711 campaign, based on presence/absence data of living specimens for molluscan species and on the Bray-Curtis similarity index (A, all samples; B, beam trawl samples only). Sample labels with depth in brackets. A similar topology was obtained using the abundance data transformed to fourth root. 
Table 3. Contribution of the species to the similarity between samples.

\begin{tabular}{lccccc}
\hline & $\begin{array}{c}\text { Av. } \\
\text { Abund }\end{array}$ & $\begin{array}{c}\text { Av. } \\
\text { Sim }\end{array}$ & $\begin{array}{c}\text { Sim/ } \\
\text { SD }\end{array}$ & $\begin{array}{c}\text { Contrib. } \\
\mathbf{\%}\end{array}$ & $\begin{array}{c}\text { Cum. } \\
\text { \% }\end{array}$ \\
\hline Group S (shallow). Average similarity: 16.93 & & & & & \\
Limopsis minuta (Philippi, 1836) & 92.20 & 6.70 & 0.57 & 39.58 & 39.58 \\
Lima marioni P. Fischer, 1882 & 18.40 & 6.47 & 0.49 & 38.21 & 77.79 \\
Antalis agililis (M. Sars in G.O. Sars, 1872) & 10.20 & 1.64 & 0.59 & 9.66 & 87.45 \\
Asperarca nodulosa (Müller, 1776) & 57.60 & 0.97 & 0.41 & 5.75 & 93.19 \\
Group D (deep). Average similarity: 11.77 & & & & & \\
Limopsis cristata Jeffreys, 1876 & 340.50 & 5.16 & 0.59 & 43.84 & 43.84 \\
Bathoxiphus ensiculus (Jeffreys, 1877) & 227.50 & 2.82 & 0.29 & 23.99 & 67.84 \\
Fissidentalium capillosum (Jeffreys, 1877) & 43.83 & 1.12 & 0.84 & 9.53 & 77.36 \\
Parvamussium propinquum (E.A. Smith, 1885) & 121.50 & 0.98 & 0.63 & 8.29 & 85.66 \\
Propeamussium lucidum (Jeffreys in & 29.50 & 0.71 & 0.40 & 6.02 & 91.67 \\
Wyville-Thomson, 1873) & & & & & \\
Groups S \& D. Average dissimilarity: 99.33 & & & & & \\
\hline
\end{tabular}

surfaces and the meshed are unequal between dredge, beam trawl and otter trawl. Table 3 shows the contribution of the species to the similarity between samples, calculated on the quantitative data for beam trawls only.

\section{Trophic groups}

Filter feeders, mostly the bivalves, account for more than half of the individuals collected (Fig. 46). Among these, Limopsis Sasso, 1827 represent roughly half of the specimens of the "filter feeders" group (but different species on the plateau and in the deeper samples), while the presence of the many ectoparasitic species (mostly, in the family Eulimidae) is testimonial from a quantitative point of view.

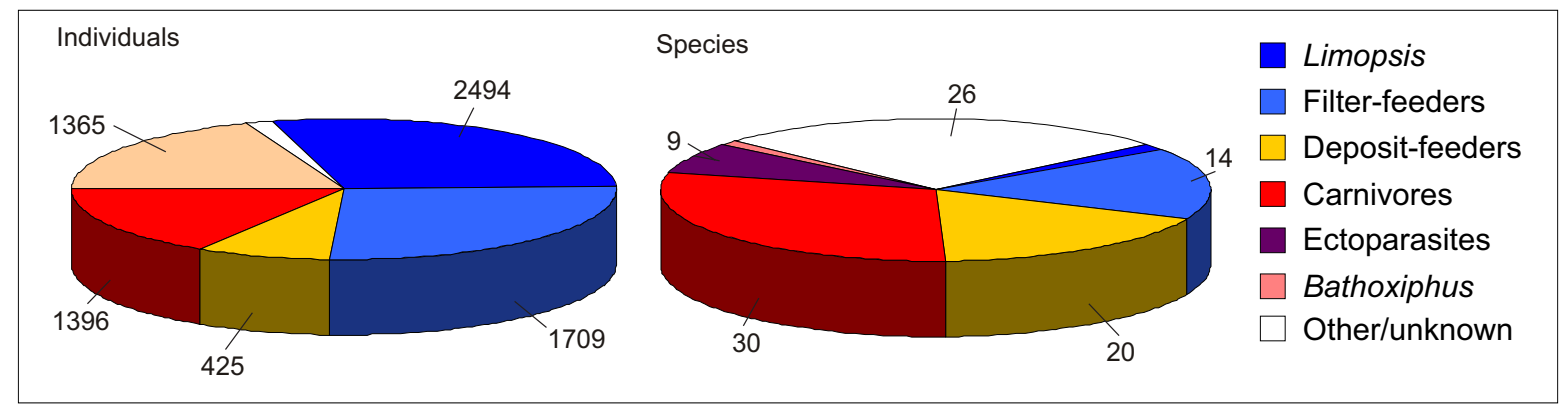

Fig. 46. Percentage of the different trophic groups, in number of live-taken individuals (left) and species represented by at least one live-taken specimen (right). 


\section{Discussion}

\section{Species diversity}

The total number of species (212) could be considered relatively low, despite having considered fractions of less than $1 \mathrm{~mm}$ and despite a broad bathymetric range, compared with 269 species on Seine Seamount and 243 on Ampère Seamount (Beck et al. 2006), located further south of GB. However, both seamounts have a shallower summit (170 m depth in Seine Seamount, which rises from more than $4000 \mathrm{~m}$, and $60 \mathrm{~m}$ in Ampère Seamount, which is part of the Horseshoe Seamounts chain and rises from $4800 \mathrm{~m}$ ) and the bathymetric range sampled was different, with the presence of several littoral species. Conversely, the GB, with a summit at $625 \mathrm{~m}$ of depth, can be classified as a deep seamount and its malacofauna is mainly constituted by deepwater species. On the other hand, GB has been considered as a site of high diversity in terms of $\gamma$-diversity regarding the decapod and fish faunas by Cartes et al. (2014) and Bañon et al. (2016), respectively. Sixty-seven species of decapod crustaceans, 6 euphausiids, 19 peracarids and 1 ostracod were recorded at depths between 744 and $1808 \mathrm{~m}$ by Cartes et al. (2014), while Bañón et al. (2016) obtained 139 species of fishes within the campaigns of the project INDEMARES, that according to these authors represent $14.6 \%$ of the 955 species listed for the European Atlantic waters.

Of the total species for which material was examined, 49 (23\%) have been collected only in one sample, and only 30 were collected in five or more. This means that most of the species have an irregular, haphazard and patchy distribution and that therefore the species collected can be a substantial underestimate of the total that really exist. Dredge DR15, as an example, yielded no less than ten species found only there, or there and in one more site. The species which appeared in more samples were the gastropods Coralliophila richardi, Colus gracilis and Amphissa acutecostata, the bivalves Asperarca nodulosa, Limopsis minuta and Delectopecten vitreus, and the scaphopod Antalis agilis.

The malacofauna of GB includes species that are usually considered rare. Representatives of the almost extinct class Monoplacophora are considered among the most unique findings in a faunistic campaign. Laevipilina rolani Warén \& Bouchet, 1990, was found in the material of the SEAMOUNT 1 at 985-1000 m (DW116). The class Scaphopoda (the scaphopods), usually considered as a 'minor class', has an unusually prominent role on the GB, especially regarding the number of individuals (1777, $25 \%$ of the total of Mollusca in BANGAL 0711 campaign). These infaunal molluscs live buried in the sediment with the tapering end emerging from the surface. The most spectacular species, and one of the largest species in the class, is Fissidentalium capillosum, collected between 1640 and $1750 \mathrm{~m}$. In shallower depths, only Antalis agilis is found, a quite ubiquitous species also present in the more muddy sediments on the continental margin.

Another unusual feature on GB is the relative abundance and diversity of the Solenogastres. These vermiform molluscs live associated with cnidarians, on which they feed, and are usually extremely rare. In the INDEMARES BANGAL 0711 campaign, 16 specimens of Solenogastres were collected in eight stations, representing at least 7 species, still awaiting study for identification or description and not taken into account in this study. It should be remembered that since the year 2000, eight new species of solenogastres have been described from the Galicia Bank (three of them giving rise to new genera; García-Alvarez et al. 2000, 2001; Garcia-Alvarez \& Salvini-Plawen 2001; García-Alvarez \& Urgorri 2001).

A few species (the gastropod Ansates pellucida and the bivalves Aequipecten opercularis, Astarte sulcata and Timoclea ovata), all of them represented by a single shell, are from shallow water. Obviously those species do not live, and did not live even during lowstands of the sea level, on GB. Their transport may have occurred through algal rafting for the first, or through the gut contents of fish moving from the shelf to the bank. 


\section{Bathymetric distribution and habitat}

Only little more than half of the species (107) were found on the summit shelf of the GB shallower than $1000 \mathrm{~m}$. On the soft bottoms of the summit platform the most abundant species was the bivalve Limopsis minuta, an epifaunal suspension-feeder, which lives attached to coarse particles by its byssus (Oliver \& Allen 1980b) and is common on seamounts elsewhere (Beck et al. 2006). Other common species at the summit were the bivalves Thyasira succisa, Spinosipella acuticostata and Haliris granulata, among others, the gastropods Gibberula abyssicola, Colus gracilis, Austrobela pyrrhogramma and Neopleurotomoides callembryon, and the scaphopod Antalis agilis. Also common in the summit are some species of the genus Anatoma (A. aspera, A. eximia, A. richardi), probably where coral debris is present.

Between 800 and $1000 \mathrm{~m}$ appear some species more or less strictly associated to the CWC, such as the gastropods Calliostoma maurolici, C. leptophyma, Coralliophila richardi, Iphitus tuberatus, Diodora tenuiclathrata, Profundisepta profundi, Puncturella agger and Emarginula christiaensi, and the bivalves Asperarca nodulosa, Lima marioni, Spondylus gussonii and Delectopecten vitreus. Epifaunal bivalves normally use the dead corals as a substrate, on which they are cemented (Spondylus) or byssally attached. Some of the abovementioned gastropods probably feed on corals, on anemones or hydroids which grow on coral skeletons (Calliostoma maurolici, C. leptophyma, Coralliophila richardi, Iphitus tuberatus), or on epifaunal sponges (Diodora tenuiclathrata, Puncturella profundi, P. agger, Emarginula christiaensi). The association of deep white Calliostoma species and CWC has been pointed out on several occasions (e.g., Beck et al. 2006; Hoffman et al. 2019a) and C. maurolici has been photographed grazing on live Madrepora oculata and on the actiniaria Phelliactis hertwigii Simon, 1892, common in the CWC framework (Hoffman et al. 2019a). On the other hand, Iphitus tuberatus, Asperarca nodulosa, Lima marioni, Delectopecten vitreus and Spondylus gussonii are common species in the Mediterranean CWC ecosystem (see Rueda et al. 2019 for a review) and they are also widespread in the N Atlantic. Hoffman \& Freiwald (2018) recorded Diodora tenuiclathrata, Puncturella profundi and Emarginula christiaensi in Pleistocene thanatocoenoses associated with CWC habitats along the continental shelf and slope off Mauritania and here only empty shells have been found, except for a living specimen of the former species. Deeper, in Rucabado seamount (stn DR14, 1130 m), where well-developed CWC reefs have been located, the epitoniid Cylindriscala thalassae and the pectinid Delectopecten vitreus have been obtained. The former is a very rare species only known previously from the type locality in the N part of the Bay of Biscay at $1055 \mathrm{~m}$ depth (Bouchet \& Warén 1986). These authors pointed out that the species of the genus Cylindriscala are probably associated to sea anemones of CWC habitats. On the other hand, $D$. vitreus is widely distributed throughout GB and is a species of wide geographical and bathymetric distribution (Janssen \& Krylova 2014).

Also noteworthy are two adjacent samples placed on the NW edge of the summit (DW116, 985-1000 m) and on the higher part of the shelf break (DW108, 1110-1125 m), where 41 and 42 species were respectively found, with 26 shared species. Quite abundant and almost exclusive of these samples are Iphitus tuberatus and Pedicularia sicula (only empty shells). This would indicate the presence in this area of CWC patches with the stylasterid coral Errina sp., because P. sicula is strictly associated to corals of that genus (Arnaud \& Zibrowius 1979). A high number of "conoidean" species were found in both samples, being especially abundant empty shells of Austrobela pyrrhogramma.

The deepest samples of the campaign BANGAL 0711, between 1600 and $1720 \mathrm{~m}$, were the most diverse. The most abundant mollusc species (not only in these samples, but in general in the campaign) were the bivalve Limopsis cristata, followed by the scaphopods Bathoxyphus ensiculus and Fissidentalium capillosum and the also epifaunal bivalve Parvamussium propinquum. The bivalves Ledella messanensis, Ennucula corbuloides and Lyonsiella abyssicola were also abundant and exclusive of the deepest samples. Among the gastropods, we noted the abundance of Scaphander punctostriatus, an infaunal 
species which feeds on small organisms, especially foraminifera, and moves within the sediment; perhaps due to this way of life we collected a large number of live juveniles, whereas adult shells were almost always empty. Also abundant in the deepest samples were Colus jeffreysianus, species of the family Eulimidae and "skeneimorph" species.

Sample V10, collected at 1720 m depth in the transition zone between the GB itself and the Inland Basin of Galicia, not far from the east cliff of the Bank, is unique. In this sample the species richness is one of the highest of the campaign (37 live collected species, 1995 individuals), with notable numbers of the carnivorous gastropods Kryptos koehleri, Colus jeffreysianus and Troschelia berniciensis, which are species shared with the slope of the continent itself along the entire Bay of Biscay and the Iberian west coast. Also in this sample, rare species such as the gastropod Aforia serranoi and the bivalve Halicardia flexuosa were found.

On the other hand, very few species were only found in samples from intermediate depths $(1000-1500 \mathrm{~m})$, all of them in low number, such as Basilissopsis watsoni, Asthelys munda, Moelleriopsis sp., Batheulima fuscoapicata, Fuscapex cabiochi, Eulitoma obtusiuscula or Cylindriscala guernei, but all of them represented only by a small number of empty shells. These depths correspond mostly to steep rocky slopes, difficult to sample with conventional gears, and are probably undersampled. Dredge BANGAL DR15 successfully sampled this interval and contains several unique species.

There is a striking pattern of congeneric species pairs occurring respectively on the summit platform and on the deeper slope below $1500 \mathrm{~m}$ : Anatoma eximia and A. richardi on the summit vs Anatoma umbilicata and $A$. corralae sp. nov. deep; Colus gracilis on the summit and Colus jeffreysianus deep; Limopsis minuta on the summit vs Limopsis cristata deep; Dacrydium wareni on the summit vs Dacrydium ockelmanni deep (see Table 2). The Limopsis species pair comprises two of the most abundant species, with hardly any overlap; the few valves of $L$. minuta collected in the deep stations being probably an artifact from specimens entangled in the trawl. This disjunct bathymetric distribution has also been reported for pairs of congeneric species of decapods by Serrano et al. (2017a).

\section{Trophic groups}

The GB is entirely situated below the photic zone and therefore the herbivorous species that predominate in shallow environments are completely absent. The species found are essentially distributed among more or less specialized filter feeders, detritivores and carnivores. Among the filter feeders are all the epifaunal bivalves, predominating quantitatively the Limopsis species, but other bivalves associated to white coral, such as Lima marioni, Asperarca nodulosa and Spondylus gussonii are also common.

Colus gracilis (Fig. 47) and C. jeffreysianus are among the largest gastropods, belonging to a genus of predatory habits, although quite eclectic in the choice of prey and occasionally scavengers. According to Kosyan (2007), stomach contents of these species revealed the presence of amphipod remains, while in other species of the same genus, foraminiferans, molluscs, brittlestars and other organisms were also detected, so everything indicates that they feed on small infaunal organisms without much specialization. There are many other species of gastropods with carnivorous habits, among which Amphissa acutecostata and Kryptos koehleri are relatively abundant.

The scaphopods, very abundant especially in the deepest samples, are known (Glover et al. 2003, with references) as predators that feed essentially on foraminifers and occasionally on other small organisms, which they collect in the sediment through tiny tentacles (the "captacules"). There are no concrete data on the diet of the species collected on GB, except those provided by Langer et al. (1995) on the genus Fissidentalium. However, for the tiny Bathoxiphus ensiculus, Steiner (1994) speculated that a 
detritivorous diet would be more likely considering its very long digestive tract; for this reason it has been scored as "unknown" in our counts.

A striking aspect in the deep benthos is the development of carnivorous habits in groups that usually are not. In this case are the bivalves Propeamussium lucidum (see Morton \& Thurston 1989) and the septibranch bivalves (Reid \& Reid 1974; Morton 1981). It is also worth mentioning the presence of the predatory polyplacophoran Placiphorella atlantica (see McLean 1962).

Among the proven detritivores can be mentioned the bivalves of the subclass Protobranchia, present although not very abundant in the deepest stations of the periphery of GB. The two species of this group that appear in a relatively high number were Ennucula corbuloides and Ledella messanensis, from which most of the specimens were collected in the V10 haul, in the transition zone towards the inner basin. In this trophic group also enter small gastropods such as Cirsonella romettensis, Benthonella tenella, Anatoma spp. and possibly the smaller scaphopods Bathoxiphus ensiculus and Pulsellum lofotense.

Some gastropods have highly specialized diets. This is the case of the tiny gastropods Lepetella sp. and Addisonia cf. excentrica, which feed respectively on the organic tubes of the onuphid polychaete Hyalinoecia Malmgren, 1867 and on egg cases of chondrichtyans. As mentioned above, there is also a close relationship between the gastropod Pedicularia Swainson, 1840 and stylasterid corals of the genus Errina Gray, 1835, typical of bathyal cliffs in current-swept hard bottoms (Arnaud \& Zibrowius 1979). The sampling of this community is very difficult and it was not collected during the BANGAL 0711 campaign, but shells of Pedicularia were collected in 1987 during the SEAMOUNT 1 campaign and indicate that this interesting community exists on the NW ridge of the Bank. To the same category of specialized carnivores belong the Calliostoma species, Coralliophila richardi and Epitoniidae species, all them feeding on anthozoans, the Eulimidae, ectoparasites of echinoderms, and the Pyramidellidae, ectoparasites of polychaetes or other molluscs. The eulimids present a high species diversity in the GB, where diverse species of echinoderms dominate in certain habitats.

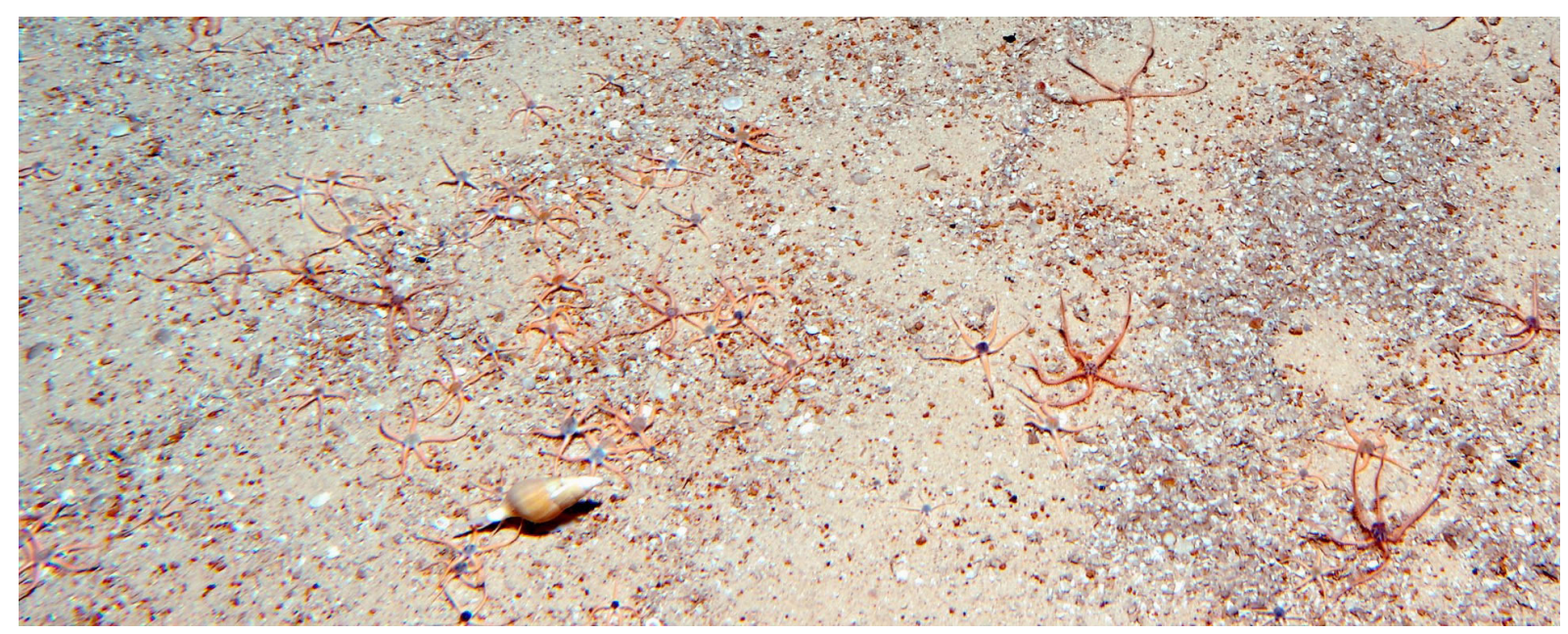

Fig. 47. A gastropod of the genus Colus Röding, 1798 (probably C. gracilis (da Costa, 1778)), roaming a sedimentary bottom of the summit platform where there are abundant brittlestars and small bivalves of the genus Limopsis Sasso, 1827 (probably L. minuta (Philippi, 1836), white dots in the photograph). Photo: Indemares project; Bangal_E09L1_0080. 


\section{Endemism and biogeographical relationships}

A certain level of endemism can be expected in the benthic fauna of a remote seamount. This is not straightforward the case of GB, which is large and not very distant from the mainland slope. In fact, hardly any species were found to be endemic of Galicia Bank. Only a few solenogastres, and the gastropod species described herein, are only known from the original lot. The rissoid Gofasia galiciae Bouchet \& Warén, 1993, at that time recorded as endemic, was later found (Gofas 2007) on other seamounts of the Ibero-Moroccan region. Souto et al. (2016) recorded 25 species of cheilostomate bryozoans in the GB, 12 of them described as new to science, and pointed out that the level of endemism could be between $48 \%$ and $60 \%$. Nevertheless, Cartes et al. (2014) only considered the two newly described species as potentially endemic species among the 67 recorded decapods, and Bañón et al. (2016) did not find any endemic species among the 139 fish recorded in the GB.

From the first studies on seamounts emerged the general paradigm that they harbour high levels of endemism (see Rowden et al. 2010 for a review). However, recent studies have questioned this paradigm (e.g., Samadi et al. 2006; McClain 2007; Castelin et al. 2010, 2011), and the levels of endemicity may vary between seamounts, regions, and taxa, and it depend of a series of factors, among other the dispersal capability of species.

The dispersal and colonization capacity of molluscs generally depends on the type of larval development, being those with a prolonged larval phase (weeks or even months) in the plankton ("planktotrophic" development, larvae feed while they are in the water column) having the greatest capacity of dispersal, but those with direct development (intracapsular larval development, without planktonic phase) have better capacity to persist once installed in a locality. Between both extremes, many mollusc species have lecithotrophic larvae (that feed on yolk, though some species can also feed in the water column) of short duration, of hours or days. The knowledge from other seamounts suggests that a distance in the order of magnitude of $200 \mathrm{~km}$ is not a barrier to the dispersal of species with a short pelagic phase, for example the trochid and rissoid gastropods (Gofas 2005, 2007) and this may apply to many other gastropods, polyplacophorans, scaphopods and bivalves. These latter species may use intermediate seamounts with suitable habitats as "stepping stones", a matter discussed by several authors (e.g., Samadi et al. 2006; McClain 2007; Castelin et al. 2010, 2011). It is not likely that the width of the Galician Inland Basin could represent a barrier, so that most species are shared with the Iberian continental margin or even more widely distributed. Compared to the Iberian margin, the differentiation as a "GB seamount fauna" is not obvious and is only manifest through the presence of species such as Seamountiella azorica, Puncturella agger, Ancistrobasis reticulata, Gofasia galiciae or Fusinus bocagei, shared with the more remote seamounts of the Northeastern Atlantic, the Azores or the South Azores Seamount Chain (Beck et al. 2006; Gofas 2000, 2007) and not found along the mainland. Only 17 species are known exclusively from Galicia Bank, and these include eight Solenogastres never recorded again after their original description, the four species described as new herein, so that the level of endemism on GB, if not nil, is certainly very low compared to more remote seamounts.

The shared GB species with other N Atlantic areas is summarized in Fig. 48. The highest number is shared with Bay of Biscay and numbers decrease in relation to more distant sites. Altogether, a majority of GB species have a relatively wide distribution in the $\mathrm{N}$ Atlantic, and the number of shared species is quite even across all the areas considered.

Considering only the species present on GB (those behind the numbers on Fig. 48), the outcome of the similarity analysis (Fig. 49) was that GB clustered with Bay of Biscay, Ibero Moroccan Gulf and British Isles (i.e., areas of the continental margin) whereas Lusitanian seamounts and the Azores clustered separately. However, this similarity analysis must also take into account the species in the 500-2000 m depth interval which are present in the other areas and not on GB. When this is implemented, GB clustered 


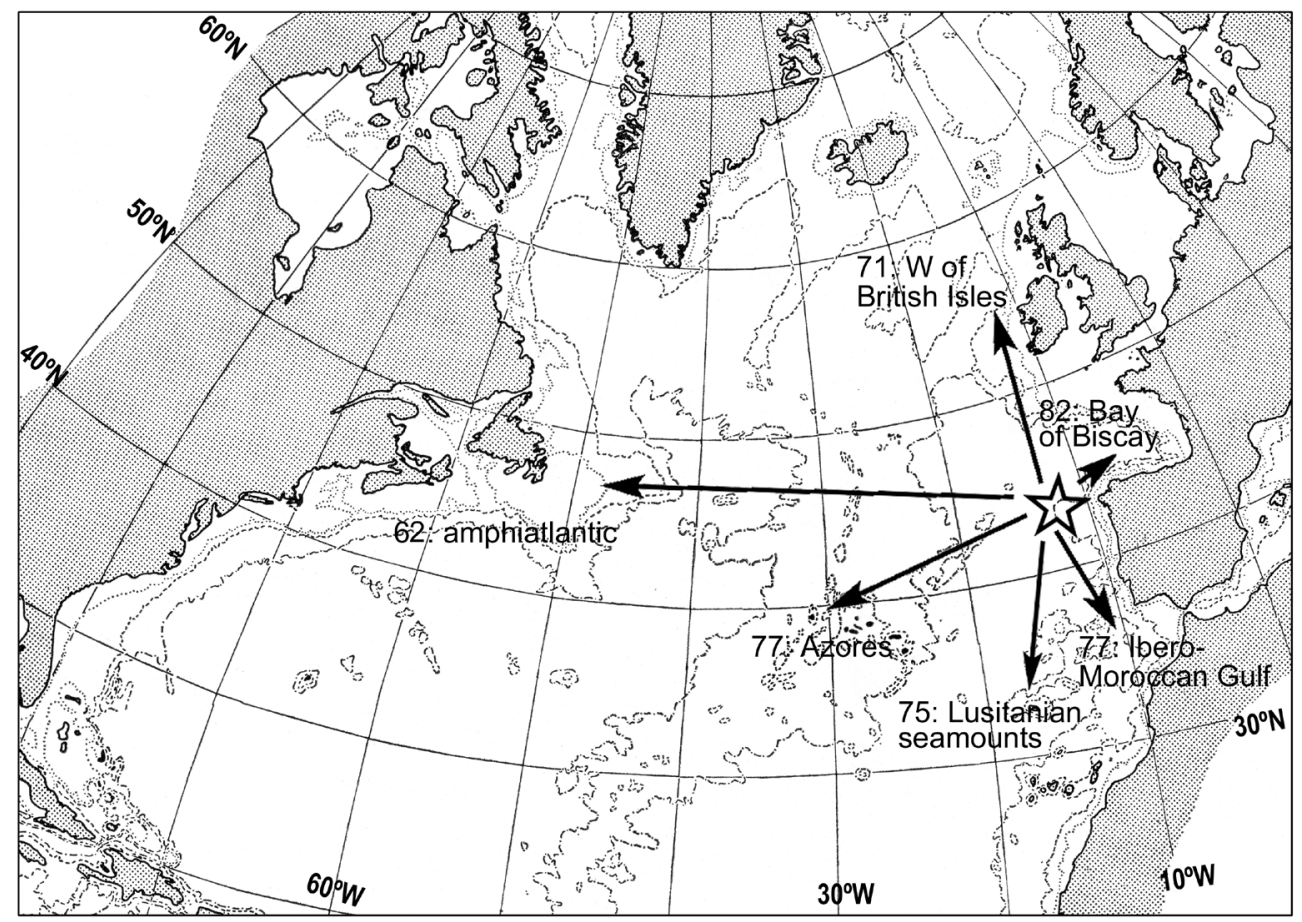

Fig. 48. Number of Galicia Bank species shared with other distant regions of the Atlantic (Bay of Biscay, Ibero-Moroccan region, seamounts of Lusitanian region and Western Atlantic).

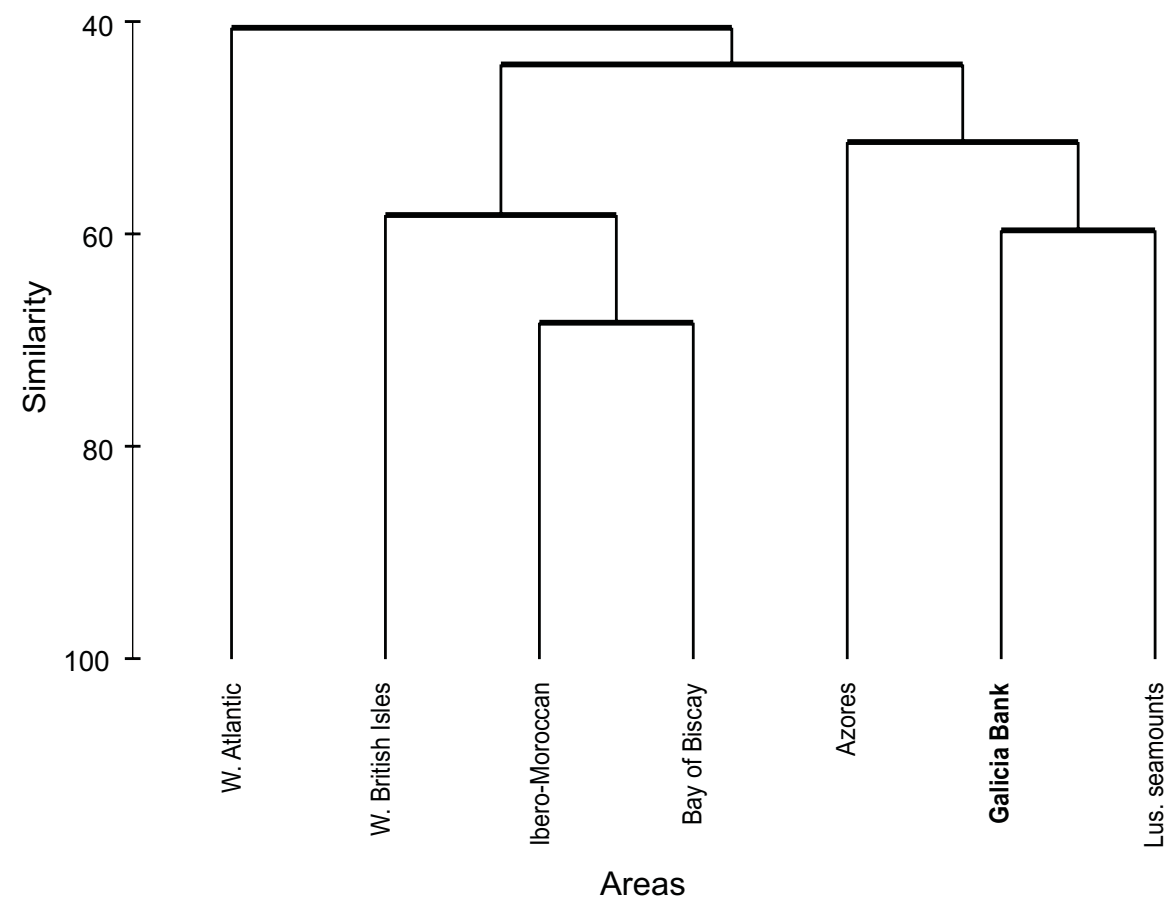

Fig. 49. Similarity between Galicia Bank and other areas of the North Atlantic, based on presence/ absence data of molluscan species and on the Bray-Curtis similarity index. Areas as on Fig. 48. 
with the Lusitanian seamounts and the Azores rather than with the mainland. We explain this because Bay of Biscay, Ibero Moroccan Gulf and British Isles slopes share many species that are not on GB, therefore supporting the consideration of GB as a seamount.

\section{Conservation issues}

It is common knowledge that the international conventions and legal texts in which species of molluscs are granted a protection regime are focused on the terrestrial and coastal environments. In the context of the Galicia Bank, and more generally of the bathyal fauna, it should be borne in mind that the species present there have never been evaluated for their possible inclusion in lists of protected or threatened species. With these circumstances, the only species collected in the GB and that is included in such lists is the gastropod Ranella olearium, listed in Annex II of the Bern and Barcelona conventions, the latter only relevant to the Mediterranean Sea. However, this lack of representation reflects the inadequacy of those lists for the management of the deep sea, rather than the lack of species of interest for conservation purposes in the area. Among molluscs present in the GB, a choice of representative species would include the oyster Neopycnodonte zibrowii, whose adult individuals may be hundreds of years old and which is structuring a habitat collected in the Spanish Inventory of Marine Habitats (code 04010403 "Scarps, walls and rocky slopes of the deep sea with Neopycnodonte zibrowii"; Templado et al. 2012). In the deepest part of the study area, species such as the scaphopod Fissidentalium capillosum and the bivalve Halicardia flexuosa, whose large size also suspect slow growth.

The GB was proposed to the European Commission to be included in the Natura 2000 list of Sites of Community Importance in 2014 (Ministerio de Agricultura, Alimentación y Medio Ambiente, 2014) and is planned to be proposed soon as Special Area of Conservation. Being huge and relatively undisturbed, it would also qualify as a UICN Type Ib area (wilderness areas, Dudley 2008) in terms of conservation goals. Nevertheless, a protection management plan is not yet approved. The remoteness and the difficult access to its vulnerable ecosystems are at the present time the better protection shield for the Galicia Bank.

\section{Acknowledgements}

This study was mainly financed by the EC contract INDEMARES-LIFE (07/NAT/E/000732). We thank all the participants and crews of the cruises ECOMARG 0709 and BANGAL 0711 performed, respectively, on board R/Vs "Cornide de Saavedra" and "Miguel Oliver", for efficient and pleasant collaboration during the cruises, and all the members of the Indemares-Bangal project team. SG and AL participated in the BANGAL 0711 cruise through collaboration agreements between the Instituto Español de Oceanografía and the University of Málaga and the Foundation of the Universidad Autónoma de Madrid. SG and AL are also grateful to Philippe Bouchet for the invitation to participate in the SEAMOUNT 1 cruise and for handing over the material for study. The authors dedicate a special thought to the late Rafael Araujo (MNCN), whose assistance with this paper was one of his last actions as a curator. We thank Vivian Brusa for her collaboration in the study of two of the BANGAL 0711 samples; Emilio Rolán, for his participation on SEAMOUNT 1 cruise and the loan of Fissurellidae material from campaigns 1980-1981 by Instituto de Investigaciones Pesqueras de Vigo-CSIC; Gregorio Martín Caballero (SCAI, Universidad de Málaga) and Enrique Rodríguez (SIDI, Universidad Autónoma de Madrid) for SEM micrographs; and Andreia Salvador and Kevin Webb (NHMUK), for the images of the syntype of Puncturella agger. We also thank Anders Warén for useful help and comments on the manuscript, and Philippe Bouchet for the background map of Fig. 48 (reproduced from Bouchet 1975).

\section{References}

Albaigés J.B., Morales-Nin B. \& Vilas F. 2006. The Prestige oil spill: a scientific response. Marine Pollution Bulletin 53: 205-207. https://doi.org/10.1016/j.marpolbul.2006.03.012 
Allen J.A. \& Hannah F.J. 1989. Studies on deep-sea Protobranchia (Bivalvia). The subfamily Ledellinae (Nuculanidae). Bulletin of the British Museum (Natural History), Zoology Series 55 (2): 123-171.

Allen J.A. \& Morgan R.E. 1981. The functional morphology of Atlantic deep water species of the families Cuspidariidae and Poromyidae (Bivalvia): an analysis of the evolution of the septibranch condition. Philosophical Transactions of the Royal Society of London 294: 413-546.

https://doi.org/10.1098/rstb.1981.0117

Allen J.A. \& Turner J.F. 1974. On the functional morphology of the family Verticordiidae (Bivalvia) with descriptions of new species from the abyssal Atlantic. Philosophical Transactions of the Royal Society of London (B) 268 (894): 401-536, pl. 58. https://doi.org/10.1098/rstb.1974.0038

Allen J.A., Sanders H.L. \& Hannah F. 1995. Studies on deep-sea Protobranchia (Bivalvia). The subfamily Yoldiellinae. Bulletin of the British Museum (Natural History) Zoology Series 61 (1): 11-90.

Alonso B., Ercilla G., Casas D., Estrada F., Farrán M., García M., Rey D. \& Rubio B. 2008. Late Pleistocene and Holocene sedimentary facies on the SW Galicia Bank (Atlantic NW Iberian Peninsula). Marine Geology 249: 46-63. https://doi.org/10.1016/j.margeo.2007.09.012

Arnaud P.M. \& Zibrowius H. 1979. L'association Pedicularia sicula - Errina aspera en Méditerranée (Gastropoda Prosobranchia et Hydrocorallia Stylasterina). Rapports et Procès-verbaux des Réunions, Commission Internationale pour l'Exploration Scientifique de la Mer Méditerranée 2526 (4): 123-124.

Ávila S.P. \& Malaquias M.A.E. 2003. Biogeographical relationships of the molluscan fauna of the Ormonde Seamount (Gorringe Bank, Northeast Atlantic Ocean). Journal of Molluscan Studies 69: 145150. https://doi.org/10.1093/mollus/69.2.145

Baba K. \& Macpherson E. 2012. A new squat lobster (Crustacea: Decapoda: Anomura: Chirostylidae) from off NW Spain. Zootaxa 3224: 49-56. https://doi.org/10.11646/zootaxa.3224.1.3

Bañón R., Arronte J.C., Rodríguez-Cabello C., Piñeiro C.G., Punzón A. \& Serrano A. 2016. Commented checklist of marine fishes from the Galicia Bank seamount (NW Spain). Zootaxa 4067 (3): 293-333. https://doi.org/10.11646/zootaxa.4067.3.2

Barrio González L. 2015. Estudio Sistemático, Anatómico y Filogenético de los Moluscos de la Subfamilia Emarginulinae (Gastropoda, Vetigastropoda, Fissurellidae) de los Fondos Batiales del Atlántico Norte. $\mathrm{PhD}$ thesis, Universidade de Santiago de Compostela. Available from http://hdl.handle.net/10347/14700 [accessed 7 Mar. 2021].

Barros J.C.N. de \& Lima S.F.B. de. 2007. Three new species of Cancellariidae (Gastropoda: Neogastropoda) from northeast Brazil with first record of Gergovia for the Atlantic Ocean. Zootaxa 1387: 59-68. https://doi.org/10.11646/zootaxa.1387.1.5

Beck T., Metzger T. \& Freiwald A. 2006. Biodiversity inventorial atlas of macrobenthic seamount animals. FAU-Friedrich Alexander University of Erlangen-Nuremberg. Available from https://epic.awi.de/id/eprint/37314/7/OASIS_BIAS.pdf [accessed 7 Mar. 2021].

Black M., Hill M.N., Laughton A.S. \& Matthews D.H. 1964. Three non-magnetic seamounts off the Iberian coast. Quarterly Journal of the Geological Society 120: 477-517.

https://doi.org/10.1144/gsjgs.120.1.0477

Bogi C. \& Giusti Fr. 1994. Emarginula tuberculosa \& Emarginula multistriata: ritrovamento di esemplari viventi. La Conchiglia 273: 41-44.

Bouchet P. 1975. Opisthobranches de profondeur de l'Océan Atlantique. I Cephalaspidea. Cahiers de Biologie Marine 16 (3): 317-365. 
Bouchet P. \& Métivier B. 1988. Campagne Océanographique "SEAMOUNT 1". Compte rendu et liste des stations. INSU/CNRS (unpublished cruise report). https://doi.org/10.5281/zenodo.5726877

Bouchet P. \& Warén A. 1980. Revision of the Northeast Atlantic bathyal and abyssal Turridae (Mollusca, Gastropoda). Journal of Molluscan Studies Supplement 8: 1-119.

https://doi.org/10.1093/mollus/46.Supplement_8.1

Bouchet P. \& Warén A. 1985. Revision of the Northeast Atlantic bathyal and abyssal Neogastropoda excluding Turridae (Mollusca, Gastropoda). Bollettino Malacologico Supplemento 1: 123-296.

https://doi.org/10.5962/bhl.title.140763

Bouchet P. \& Warén A. 1986. Revision of the Northeast Atlantic bathyal and abyssal Aclidiidae, Eulimidae, Epitoniidae (Mollusca, Gastropoda). Bollettino Malacologico Supplemento 2: 297-576. https://doi.org/10.5962/bhl.title.140762

Bouchet P. \& Warén A. 1993. Revision of the Northeast Atlantic bathyal and abyssal Mesogastropoda. Bollettino Malacologico Supplemento 3: 577-840. https://doi.org/10.5962/bhl.title.140732

Cartes J.E., Papiol V., Frutos I., Macpherson E., González-Pola C., Punzón A., Valeiras X. \& Serrano A. 2014. Distribution and biogeographic trends of decapod assemblages from Galicia Bank (NE Atlantic) at depths between 700 and $1800 \mathrm{~m}$, with connexions to regional water masses. Deep Sea Research II 106: 165-178. https://doi.org/10.1016/j.dsr2.2013.09.034

Castelin M., Lambourdiere J., Boisselier C., Lozouet P., Coloux A., Cruaud C. \& Samadi S. 2010. Hidden diversity and endemism on seamounts: focus on poorly dispersive neogastropods. Biological Journal of the Linnean Society 100 (2): 420-438. https://doi.org/10.1111/j.1095-8312.2010.01424.x

Castelin M., Puillandre N., Lozouet P., Sysoev A., Richer de Forges B. \& Samadi S. 2011. Molluscan species richness and endemism on New Caledonian seamounts: are they enhanced compared to adjacent slopes? Deep Sea Research I 58 (6): 637-646. https://doi.org/10.1016/j.dsr.2011.03.008

Clark M.R., Rowden A.A., Schlacher T., Williams A., Consalvey M., Stocks K.I., Rogers A.D., O'Hara T.D., White M., Shank T.M. \& Hall-Spencer J.M. 2010. The ecology of seamounts: structure, function, and human impacts. Annual Review of Marine Science 2: 253-278.

https://doi.org/10.1146/annurev-marine-120308-081109

Clarke K.R. 1993. Non-parametric multivariate analyses of changes in community structure. Australian Journal of Ecology 18: 117-143. https://doi.org/10.1111/j.1442-9993.1993.tb00438.x

Clarke K.R. \& Warwick R.M. 1994. Change in Marine Communities: An Approach to Statistical Analysis and Interpretation. Plymouth Marine Laboratory, Plymouth.

Corral Prado E. 2006. Moluscos Gasterópodos Prosobranquios da familia Fissurellidae recollidos na campaña francesa Seamount 1. Graduate student project, Universidade de Santiago de Compostela.

Council of the European Communities. 1992. Council Directive 92/43/EEC of 21. May 1992 on the conservation of natural habitats and of wild fauna and flora. Official Journal of the European Communities 35: 7-50.

Cristobo J., Ríos P., Pomponi S.A. \& Xavier J. 2015. A new carnivorous sponge, Chondrocladia robertballardi sp. nov. (Porifera: Cladorhizidae) from two north-east Atlantic seamounts. Journal of the Marine Biological Association of the United Kingdom 95 (7): 1345-1352.

https://doi.org/10.1017/S0025315414001325

Dall W.H. 1882. On certain limpets and chitons from the deep waters off the eastern coast of the United States. Proceedings of the United States National Museum 4: 400-414.

https://doi.org/10.5479/si.00963801.4-246.400 
Dall W.H. 1927. Small shells from dredgings off the southeast coast of the United States by the United States Fisheries Steamer Albatross, in 1885 and 1886. Proceedings of the United States National Museum 70 (2667): 1-134. https://doi.org/10.5479/si.00963801.70-2667.1

Dantart L. \& Luque A. 1994. Cocculiniformia and Lepetidae (Gastropoda: Archaeogastropoda) from Iberian waters. Journal of Molluscan Studies 60: 277-313. https://doi.org/10.1093/mollus/60.3.277

Dautzenberg P. \& Fischer H. 1896. Dragages effectués par l'Hirondelle et par la Princesse Alice 18881895. 1. Mollusques Gastéropodes. Mémoires de la Société zoologique de France 9: 395-498, pl. 15-22.

Dautzenberg P. \& Fischer H. 1897. Dragages effectués par l'Hirondelle et par la Princesse Alice 18881896. Mémoires de la Société zoologique de France 10: 139-234, pl. 3-7.

de la Torriente A., Serrano A., Druet M., Gómez-Ballesteros M., Acosta J., Parra S., et al. 2014. Banco de Galicia. Áreas de estudio del proyecto LIFE + INDEMARES. Proyecto LIFE + INDEMARES, Fundación Biodiversidad del Ministerio de Agricultura, Alimentación y Medio Ambiente, Madrid. Available from https://www.indemares.es/sites/default/files/banco_de_galicia.pdf [accessed 7 Mar. 2021].

Di Geronimo I. \& La Perna R. 1997. Pleistocene bathyal molluscan assemblages from southern Italy. Revista Italiana di Paleontologia e Stratigrafia 103 (3): 389-426.

Dijkstra H.H. \& Gofas S. 2004. Pectinoidea (Bivalvia: Propeamussiidae and Pectinidae) from some northeastern Atlantic seamounts. Sarsia 89 (1): 33-78. https://doi.org/10.1080/00364820410003469

Dudley N. (ed.) 2008. Guidelines for Applying Protected Area Management Categories. IUCN, Gland, Switzerland. WITH Stolton S., Shadie P. \& Dudley N. 2013. IUCN WCPA Best Practice Guidance on Recognising Protected Areas and Assigning Management Categories and Governance Types, Best Practice Protected Area Guidelines Series No. 21, IUCN, Gland, Switzerland. Available from https://portals.iucn.org/library/sites/library/files/documents/PAG-021.pdf [accessed 7 Mar. 2021].

Duineveld G.C.A., Lavaleye M.S.S. \& Berghuis E.M. 2004. Particle flux and food supply to a seamount cold-water coral community (Galician Bank, NW Spain). Marine Ecology Progress Series 277: 13-23. https://doi.org/10.3354/meps277013

Ercilla G. \& Vilas F. 2008. Geological characterization of the Galicia Bank Region (Atlantic Ocean, NW Iberia): the marine geology community's response to the Prestige disaster. Marine Geology 249: 1-6. https://doi.org/10.1016/j.margeo.2007.09.008

Ercilla G., Casas D., Vázquez J.T., Iglesias J., Somoza L., Juan C., Medialdea T., León R., Estrada F., García-Gil S., Farrán M., Bohoyo F., García M. \& Maestro A. 2011. Imaging the recent sediment dynamics of the Galicia Bank Region (Atlantic, NW Iberian Peninsula). Marine Geophysical Research 32: 99-126. https://doi.org/10.1007/s11001-011-9129-x

Engl W., Swinnen F. \& Hoffman L. 2021. A review of species in Fusceulima (Gastropoda: Eulimidae) from the NE Atlantic Ocean and the Western Mediterranean Sea with illustration of key type specimens. Conchylia 51 (3-4): 3-16.

Fechter R. 1979. Gastropoden aus der Iberischen Tiefsee. Meteor Forchungs-Ergebnisse (D) 30: 23-40.

Fiúza A.F.G., Hamann M., Ambar I., Díaz del Río G., González N. \& Cabanas J.M. 1998. Water masses and their circulation off western Iberia during May 1993. Deep Sea Research I 45: 1127-1160. https://doi.org/10.1016/S0967-0637(98)00008-9

Flach E., Muthumbi A. \& Heip C. 2002. Meio- and macrofauna community structure in relation to sediment composition at the Iberian margin compared to the Goban Spur (NE Atlantic). Progress in Oceanography 52 (2-4): 433-457. https://doi.org/10.1016/S0079-6611(02)00018-6 
Forbes E. \& Hanley S.C. 1849-1850. A History of British Mollusca and their Shells. Vol. 2: 1-480 [1 dec. 1849], 481-557 [1850]. Van Voorst, London. https://doi.org/10.5962/bhl.title.16341

Garcia-Alvarez O. \& Salvini-Plawen L.v. 2001. Urgorria compostelana gen. et sp. nov. (Mollusca, Solenogastres, Rhopalomeniidae), a new species from off Galicia, Northwest of Spain. Sarsia 86 (3): 183-189. https://doi.org/10.1080/00364827.2001.10420474

García-Alvarez O. \& Urgorri V. 2001. Luitfriedia minuta gen. et sp. nov. (Mollusca: Solenogastres), a new species from Galicia, North-West Spain. Cahiers de Biologie Marine 42: 197-202.

García-Alvarez O., Urgorri V. \& Salvini-Plawen L.v. 2000. Sputoherpia galliciensis, a new species from off Galicia (Mollusca, Solenogastres: Amphimeniidae). Ophelia 53 (3): 181-188.

https://doi.org/10.1080/00785326.2000.10409448

García-Alvarez O., Salvini-Plawen L.v. \& Urgorri V. 2001. Unciherpia hirsuta a new genus and species of Aplacophoran (Mollusca Solenogastres: Pararrhopaliidae) from Galicia, Northwest Spain. Journal of Molluscan Studies 67: 113-119. https://doi.org/10.1093/mollus/67.1.113

Geiger D.L. 2012. Monograph of the Little Slit Shells. Santa Barbara Museum of Natural History, Santa Barbara.

Glover E., Taylor J. \& Whittaker J. 2003. Distribution, abundance and foraminiferal diet of an intertidal scaphopod, Laevidentalium lubricatum, around the Burrup Peninsula, Dampier, Western Australia. In: Wells F.E., Walker D.I. \& Jones D.S. (eds) The Marine Flora and Fauna of Dampier, Western Australia: 225-240. Western Australiam Museum, Perth.

Gofas S. 2000. Four species of the family Fasciolariidae (Gastropoda) from the North Atlantic seamounts. Journal of Conchology 37 (1): 7-16.

Gofas S. 2002. An endemic radiation of Trituba (Mollusca, Gastropoda) on the north Atlantic seamounts. American Malacological Bulletin 17 (1-2): 45-63.

Gofas S. 2005. Geographical differentiation in Clelandella (Gastropoda: Trochidae) in the northeastern Atlantic. Journal of Molluscan Studies 71: 133-144. https://doi.org/10.1093/mollus/eyi016

Gofas S. 2007. Rissoidae (Mollusca: Gastropoda) from northeast Atlantic seamounts. Journal of Natural History 41 (13-16): 779-885. https://doi.org/10.1080/00222930701298085

Gofas S. \& Beu A. 2002. Tonnoidean gastropods of the North Atlantic seamounts and the Azores. American Malacological Bulletin 17: 91-108.

Gofas S. \& Hoffman L. 2020. Deep-water Calliostomatidae (Vetigastropoda, Gastropoda) from the South Azorean Seamount Chain. Iberus 38 (2): 195-211.

Gofas S., Kantor Y. \& Luque Á.A. 2014a. A new Aforia (Gastropoda: Conoidea: Cochlespiridae) from Galicia Bank (NW Iberian Peninsula). Iberus 32 (1): 45-51. https://doi.org/10.5281/zenodo.4583436

Gofas S., Salas C. \& Luque Á.A. 2014b. Anexo 6 - Informe sobre los Moluscos del banco de Galicia. In: Informe final del proyecto LIFE + INDEMARES (LIFE07/NAT/E/000732) "Caracterización ecológica del banco de Galicia”: 181-195. Instituto Español de Oceanografía, Santander and Fundación Biodiversidad, Madrid.

Gofas S., Luque Á.A., Templado J. \& Salas C. 2017. A national checklist of marine Mollusca in Spanish waters. Scientia Marina 81 (2): 241-254, and supplementary material.

https://doi.org/10.3989/scimar.04543.21A

Gubbay S. 2003. Seamounts of the North-East Atlantic. OASIS (Oceanic Seamounts: an Integrated Study). Hamburg \& WWF, Frankfurt am Main, Germany. 
Hadley A. 2006. Combine ZP public domain image processing software. Available from https://web.archive.org/web/20160221032141/http://www.hadleyweb.pwp.blueyonder.co.uk/ [accessed 7 Mar. 2021].

Haszprunar G., Speimann E., Hawe A. \& Heß M. 2011. Interactive 3D anatomy and affinities of the Hyalogyrinidae, basal Heterobranchia (Gastropoda) with a rhipidoglossate radula. Organisms, Diversity \& Evolution 11: 201-236. https://doi.org/10.1007/s13127-011-0048-0

Haszprunar G., Kunze T., Brückner M. \& Heß M. 2016. Towards a sound definition of Skeneidae (Mollusca, Vetigastropoda): 3D interactive anatomy of the type species, Skenea serpuloides (Montagu, 1808) and comments on related taxa. Organisms, Diversity and Evolution 16: 577-595. https://doi.org/10.1007/s13127-015-0260-4

Heezen B. 1959. Dynamic processes of abyssal sedimentation: erosion, transportation, and redeposition on the deep-sea floor. Geophysical Journal of the Royal Astronomical Society 2 (2): 142-172.

https://doi.org/10.1111/j.1365-246X.1959.tb05790.x

Hoffman L. \& Freiwald A. 2017. A unique and diverse amalgamated mollusk assemblage from the Coral Patch Seamount, eastern Atlantic. Miscellanea Malacologica 7 (4): 61-79.

Hoffman L. \& Freiwald A. 2018. Last snails standing: a tale of Fissurellidae (Gastropoda) from deepwater coral habitats off Mauritania since the Pleistocene. Miscellanea Malacologica 7 (6): 115-126.

Hoffman L., van Heugten B. \& Lavaleye M.S.S. 2010. Skeneimorph species (Gastropoda) from the Rockall and Hatton Banks, northeastern Atlantic Ocean. Miscellanea Malacologica 4 (4): 47-61.

Hoffman L., van Heugten B. \& Lavaleye M.S.S. 2011a. Gastropoda (Mollusca) from the Rockall and Hatton Banks, northeastern Atlantic Ocean. Part 2. Miscellanea Malacologica 4 (6): 85-118.

Hoffman L., van Heugten B. \& Lavaleye M.S.S. 2011b. Gastropoda (Mollusca) from the Rockall and Hatton Banks, northeastern Atlantic Ocean. Part 3. Miscellanea Malacologica 5 (2): 23-52.

Hoffman L., Beuck L., van Heugten B., Lavaleye M.S.S. \& Freiwald A. 2019a. Last snails standing since the Early Pleistocene, a tale of Calliostomatidae (Gastropoda) living in deep-water coral habitats in the north-eastern Atlantic. Zootaxa 4613 (1): 93-110. https://doi.org/10.11646/zootaxa.4613.1.4

Hoffman L., Lavaleye M.S.S., Freiwald A. \& van Heugten B. 2019b. Lepetella (Gastropoda: Lepetellidae) in deep-water coral habitats in the North Atlantic. Miscellanea Malacologica 8 (1): 19-26.

Hoffman L., Gofas S. \& Freiwald A. 2020a. New and little-known Seguenziidae (Vetigastropoda, Gastropoda) from the South Azorean Seamount Chain. Iberus 38 (1): 1-18.

Hoffman L., Gofas S. \& Freiwald A. 2020b. Ten new species in Papuliscala de Boury, 1911 (Gastropoda, Epitoniidae) from the South Azorean Seamount Chain. Iberus 38 (1): 29-53.

Hoffman L., Gofas S. \& Freiwald A. 2020c. A large biodiversity of "skeneimorph" (Gastropoda, Vetigastropoda) from the South Azorean Seamount Chain with the description of seventeen new species. Iberus supplement 9: 1-82.

Høisæter T. \& Geiger D.L. 2011. Species of Anatoma (Gastropoda: Anatomidae) in Norwegian and adjacent waters, with the description of two new species. The Nautilus 125 (3): 89-112.

Huber M. 2010. Compendium of Bivalves. A Full-color Guide to 3,300 of the World's Marine Bivalves. A status on Bivalvia after 250 Years of Research. ConchBooks, Hackenheim.

Janssen R. \& Krylova E.M. 2014. Deep-sea fauna of European seas: An annotated species check-list of benthic invertebrates living deeper than $2000 \mathrm{~m}$ in the seas bordering Europe. Bivalvia. Invertebrate Zoology 11 (1): 43-82. https://doi.org/10.15298/invertzool.11.1.06 
Jeffreys J.G. 1878-1885. On the Mollusca procured during the H.M.S. "Lightning" and "Porcupine" expedition. Proceedings of the Zoological Society of London. Part 1 (1878): 393-416, pls 22-23; Part 2 (1879): 553-588 pl. 45-46 [October 1879]; Part 3 (1881): 693-724, pl. 61; Part 4 (1881): 922-952, pls 70-71 [1882]; Part 5 (1882): 656-687, pls 49-50 [1883]. Part 6 (1883): 88-115 pls 19-20; Part 7 (1884): 111-149, pls 9-10; Part 8 (1884): 341-372, pls 26-28; Part 9 (1885): 27-63 pls 4-6.

Kano Y., Chikyu E. \& Warén A. 2009. Morphological, ecological and molecular characterization of the enigmatic planispiral snail genus Adeuomphalus (Vetigastropoda: Seguenzioidea). Journal of Molluscan Studies 75 (4): 397-418. https://doi.org/10.1093/mollus/eyp037

Killeen I.J. \& Turner J.A. 2009. Yoldiella and Portlandia (Bivalvia) from the Faroe-Shetland Channel and Rockall Trough, northeast Atlantic. Journal of Conchology 39 (6): 733-778.

Kosyan A.R. 2007. Morphological features, ecology, and distribution of poorly studied molluscan genera of the Colinae subfamily (Gastropoda, Buccinidae) from the far eastern seas of Russia. Oceanology 47 (4): 531-536. https://doi.org/10.1134/S0001437007040108

Krylova E.M. 1995. Dvustvorchatye molliuski semeistva Protocuspidariidae (Septibranchia, Cuspidarioidea): Sostav i osobennosti resprostraneniia. [Clams of the family Protocuspidariidae (Septibranchia, Cuspidarioidea): taxonomy and distribution]. Zoologicheskii Zhurnal 74: 20-38. [In Russian.]

Krylova E.M. 2006. Bivalves of seamounts of the north-eastern Atlantic. In: MironovA.N., GebrukA.V.\& Southward A.J. (eds) Biogeography of the North Atlantic Seamounts: 76-95. KMK Press, Moscow.

Langer M.R., Lipps J.H. \& Moreno G. 1995. Predation on foraminifera by the dentaliid deep-sea scaphopod Fissidentalium megathyris. Deep Sea Research I 42 (6): 849-857.

https://doi.org/10.1016/0967-0637(95)00025-2

Lavaleye M.S.S., Duineveld G.C.A., Berghuis E.M. \& Witbaard R. 2002. A comparison between the megafauna communities on the NW Iberian and Celtic continental margins-effects of coastal upwelling? Progress in Oceanography 52: 459-476.

Lima S.F.B., Guimarães C.R.P. \& Simone L.R.L. 2015. Lepetella furuncula sp. nov. (Vetigastropoda: Lepetelloidea): the first species of the genus discovered in the South Atlantic Ocean (northeastern Brazil). Bulletin of Marine Science 92: 257-262.

Lima S.F.B., Simone L.R.L. \& Guimarães C.R.P. 2016. Addisonia enodis (Vetigastropoda: Lepetelloidea) associated with an elasmobranch egg capsule from the South Atlantic Ocean and the discovery of the species from deep waters off northeastern Brazil. Biota Neotropica 16 (3): e20160202.

https://doi.org/10.1590/1676-0611-BN-2016-0202

Locard A. 1897-1898. Expéditions scientifiques du Travailleur et du Talisman pendant les années 1880, 1881, 1882 et 1883. Mollusques testacés. Masson, Paris. https://doi.org/10.5962/bhl.title.98313

Mariottini P., Smriglio C. \& Oliverio M. 2000. The Ringicula leptocheila complex, with the description of a new species (Opisthobranchia Ringiculidae). Bollettino Malacologico 36 (5-8): 71-82.

Marquet R. 1995. Pliocene gastropod faunas from Kallo (Oost-Vlaanderen, Belgium) - Part 1. Introduction and Archaeogastropoda. Mededelingen van de Werkgroep voor Tertiaire en Kwartaire Geologie 32 (1-3): 53-85.

McClain C.R. 2007. Seamounts: identity crisis or split personality? Journal of Biogeography 34 (12): 2001-2008. https://doi.org/10.1111/j.1365-2699.2007.01783.x

McLean J.H. 1962. Feeding behavior of the chiton Placiphorella. Proceedings of the Malacological Society of London 35: 23-26. 
McLean J.H. 1985. The Archaeogastropod Family Addisoniidae Dall, 1882: life habit and review of species. The Veliger 28 (1): 99-108.

Micali P. \& Villari A. 1989. I1 deposito fossilifero di Salìce (Messina) con particolare riferimento alle specie istituite da Giuseppe Seguenza. Bollettino Malacologico 25 (1-4): 77-84.

Ministerio de Agricultura, Alimentación y Medio Ambiente. 2014. Orden AAA/1299/2014, de 9 de julio, por la que se aprueba la propuesta de inclusión en la lista de lugares de importancia comunitaria de la Red Natura 2000 de los espacios marinos ESZZ16001 Sistema de cañones submarinos occidentales del Golfo de León, ESZZ16002 Canal de Menorca, ESZZ12002 Volcanes de fango del Golfo de Cádiz y ESZZ12001 Banco de Galicia. Boletín Oficial del Estado 2014 (176): 58534-58542.

Morton B. 1981. Prey capture in the septibranch Poromya granulata (Bivalvia: Anomalodesmata: Poromyacea). Sarsia 66 (4): 241-256. https://doi.org/10.1080/00364827.1981.10414543

Morton B. \& Thurston M.H. 1989. The functional morphology of Propeamussium lucidum (Bivalvia: Pectinacea), a deep-sea predatory scallop. Journal of Zoology 218 (3): 471-496.

https://doi.org/10.1111/j.1469-7998.1989.tb02558.x

Ockelmann K. \& Warén A. 1998. Taxonomy of and biological notes on the bivalve genus Microgloma, with comments on protobranch nomenclature. Ophelia 48 (1): 1-24.

https://doi.org/10.1080/00785236.1998.10428674

Oliver P.G. 2012. Taxonomy of some Galeommatoidea (Mollusca, Bivalvia) associated with deep-sea echinoids: a reassessment of the bivalve genera Axinodon Verrill \& Bush, 1898 and Kelliola Dall, 1899 with descriptions of new genera Syssitomya gen. nov. and Ptilomyax gen. nov. European Journal of Taxonomy 12: 1-24. https://doi.org/10.5852/ejt.2012.12

Oliver P.G. 2013. Description of Atopomya dolobrata gen. et sp. nov.: first record of bacterial symbiosis in the Saxicavellinae (Bivalvia). Journal of Conchology 41 (3): 359-367.

Oliver G. \& Allen J.A. 1980a. The functional and adaptive morphology of the deep-sea species of the Arcacea (Mollusca: Bivalvia) from the Atlantic. Philosophical Transactions of the Royal Society B: Biological Sciences 291 (1045): 45-76. https://doi.org/10.1098/rstb.1980.0127

Oliver G. \& Allen J.A. 1980b. The functional and adaptative morphology of deep-sea species of the family Limopsidae (Bivalvia: Arcoida) from the Atlantic. Philosophical Transactions of the Royal Society B: Biological Sciences 291 (1045): 77-125. https://doi.org/10.1098/rstb.1980.0128

Oliver P.G., Holmes A.M., Killeen I.J. \& Turner J.A. 2016. Marine Bivalve Shells of the British Isles. Amgueddfa Cymru - National Museum Wales. Available from http://naturalhistory.museumwales.ac.uk/britishbivalves [accessed 7 Mar. 2021].

Ortega J. \& Gofas S. 2019. The unknown bathyal of the Canaries: new species and new records of deepsea Mollusca. Zoosystema 41 (26): 513-551. https://doi.org/10.5252/zoosystema2019v41a26

OSPAR Commission. 2008. OSPAR List of Threatened and/or Declining Species and Habitats. Reference number 2008-6. Available from http://www.ospar.org/documents/ [accessed 7 Mar. 2021].

OSPAR Commission. 2010. Background document for seamounts. OSPAR Commission, biodiversity series. Available from

https://www.ospar.org/about/publications?q=Background + document + for + seamounts $\& a=\& y=[$ accessed 7 Mar. 2021]

Peñas A. \& Rolán E. 1999. Pyramidellidae (Gastropoda, Heterostropha) de la misión oceanográfica “Seamount 2". Iberus suplemento 5: 151-199. https://doi.org/10.5281/zenodo.4731128 
Peñas A., Rolán E. \& Swinnen F. 2019. Pyramidellidae (Gastropoda, Heterobranchia) from the EMEPC/ $\mathrm{PEPC} / \mathrm{Luso} / 2012$ oceanographic expedition to Josephine Seamount in the Northern Atlantic. Iberus 37 (1): 7-21.

Pérez Farfante I. 1947. The genera Zeidora, Nesta, Emarginula, Rimula and Puncturella in the western Atlantic. Johnsonia 2: 93-148.

Petit R.E. 1986. Notes on species of Brocchinia (Gastropoda: Cancellariidae). The Nautilus 100: 23-27. https://doi.org/10.5962/bhl.part.26490

Piani P. 1985. Revisione del genere Emarginula Lamarck, 1801 in Mediterraneo. Lavori, Società Italiana di Malacologia 21: 193-238.

Reid R.G.B. \& Reid A.M. 1974. The carnivorous habit of members of the septibranch genus Cuspidaria (Mollusca: Bivalvia). Sarsia 56: 47-56. https://doi.org/10.1080/00364827.1974.10411261

Rogers A.D. 1994. The biology of seamounts. Advances in Marine Biology 30: 305-350. https://doi.org/10.1016/S0065-2881(08)60065-6

Rogers A.D. 2018. The biology of seamounts: 25 years on. Advances in Marine Biology 79: 137-224. https://doi.org/10.1016/bs.amb.2018.06.001

Rolán Mosquera E. 1983. Moluscos de la ría de Vigo 1. Gasterópodos. Thalassas 1 (1) Anexo 1: 1-383.

Rolán E. \& Hernández J.M. 2009. Nueva información sobre el Género Brocchinia (Gastropoda, Cancellariidae) en Canarias. Revista de la Academia Canaria de Ciencias 20 (3-4): 103-109.

Rolán Mosquera E. \& Pérez-Gándaras G. 1981. Molluscs collected at the Galicia Bank (Spain). La Conchiglia 13 (150-151): 6-7, 10, 15.

Rolán E. \& Suárez M. 2007. Primera cita de Calliostoma leptophyma (Mollusca, Calliostomatidae) para aguas de la Península Ibérica. Noticiario de la Sociedad Española de Malacología 47: 39-43.

Rolán E., Otero Schmitt J. \& Rolán Álvarez E. 1990. Moluscos de la Ría de Vigo II. Poliplacóforos, Bivalvos, Escafópodos, Cefalópodos. Thalassas Anexo 2: 1-276.

Rosenberg G. 2009. Malacolog 4.1.1: A Database of Western Atlantic Marine Mollusca. [WWW database (version 4.1.1)]. Available from http://www.malacolog.org/ [accessed 28 May 2021].

Rowden A.A., Dower J.F., Schlacher T.A., Consalvey M. \& Clark M.R. 2010. Paradigms in seamount ecology: fact, fiction and future. Marine Ecology 31 (Suppl. 1): 226-241.

https://doi.org/10.1111/j.1439-0485.2010.00400.x

Rubio F. \& Rolán E. 2013. Some new species of Skeneinae (Prosobranchia, Turbinidae). Iberus 31 (1): 1-9. https://doi.org/10.5281/zenodo.4579452

Rueda J.L., Urra J., Aguilar R., Angeletti L., Bo M. et al. 2019. Cold-water coral associated fauna in the Mediterranean Sea and adjacent areas. In: Orejas C. \& Jiménez C. (eds). Mediterranean Cold-Water Corals: Past, Present and Future: 295-333. Coral Reefs of the World vol. 9. Springer, Cham.

https://doi.org/10.1007/978-3-319-91608-8

Salas C. 1996. Marine Bivalves from off the Southern Iberian Peninsula collected by the Balgim and Fauna I expeditions. Haliotis 25: 33-100.

Salas C. \& Gofas S. 1997. Brooding and non-brooding Dacrydium (Bivalvia, Mytilidae): a review of the Atlantic species. Journal of Molluscan Studies 63 (2): 261-283. https://doi.org/10.1093/mollus/63.2.261

Salas C., Gofas S., Luque Á.A. \& Serrano A. 2011. Megabenthic mollusca collected in the bathyal zone NW Iberian Peninsula by the ECOMARG programme. $6^{\text {th }}$ Congress of the European Malacological Societies: 108. 
Salvini-Plawen L.v. 2006. Five new Iberian Neomeniamorpha (Mollusca, Solenogastres). Iberus 24 (2): 1-26. https://doi.org/10.5281/zenodo.4531182

Samadi S., Bottan L., Macpherson E., Richer De Forges B. \& Boisselier M.C. 2006. Seamount endemism questioned by the geographic distribution and population genetic structure of marine invertebrates. Marine Biology 149: 1463-1475. https://doi.org/10.1007/s00227-006-0306-4

Sanders H.L. \& Allen J.A. 1973. Studies on deep-sea Protobranchia (Bivalvia) Prologue and the Pristiglomidae. Bulletin of the Museum of Comparative Zoology, Harvard 145 (6): 237-262. Available from https://www.biodiversitylibrary.org/page/4336413 [accessed 7 Mar. 2021].

Sanders H.L. \& Allen J.A. 1977. Studies on deep-sea Protobranchia (Bivalvia). The family Tindariidae and the genus Pseudotindaria. Bulletin of the Museum of Comparative Zoology, Harvard 148 (2): 2359. Available from https://www.biodiversitylibrary.org/page/4314803 [accessed 7 Mar. 2021].

Seguenza G. 1863. Paleontologia malacologica delle rocce terziarie del distretto di Messina studiata nei suoi rapporto zoologici e geognostici. Annali dell'Accademia degli Aspiranti Naturalisti, Napoli 3 (2): $2-77$.

Seguenza G. 1877a. Studi stratigrafici sulla formazione pliocenica dell'Italia meridionale. Bollettino dell R. Comitato Geologico d'Italia 8: 91-99.

Seguenza G. 1877b. Nuculidi terziarie rinvenute nelle provincie meridionali d'Italia. Atti della Reale Accademia dei Lincei, Memorie della Classe di Scienze Fisiche, Matematiche e Naturali (3) 274 (1): 1163-1200. https://doi.org/10.5962/bhl.title.12578

Serrano A., Cartes J.E., Papiol V., Punzón A., García-Alegre A., Arronte J.C., Ríos P., Lourido A., Frutos I. \& Blanco M. 2017a. Epibenthic communities of sedimentary habitats in a NE Atlantic deep seamount (Galicia Bank). Journal of Sea Research 130: 154-165.

https://doi.org/10.1016/j.seares.2017.03.004

Serrano A., González-Irusta J.M., Punzón A., García-Alegre A., Lourido A., Ríos P., Blanco M., GómezBallesteros M., Druet M., Cristobo J. \& Cartes J.E. 2017b. Deep-sea benthic habitats modeling and mapping in a NE Atlantic seamount (Galicia Bank). Deep Sea Research I 126: 115-127.

https://doi.org/10.1016/j.dsr.2017.06.003

Simone L.R.L. 1996. Addisonia enodis, a new species of Addisoniidae (Mollusca, Archaeogastropoda) from the southern Brazilian coast. Bulletin of Marine Science 58 (3): 775-785.

Simone L.R.L. \& Cunha C.M. 2014. Taxonomical study on the mollusks collected in Marion-Dufresne (MD55) and other expeditions to SE Brazil: the Fissurellidae (Mollusca, Vetigastropoda). Zootaxa 3835 (4): 437-468. https://doi.org/10.11646/zootaxa.3835.4.2

Somoza L., Ercilla G., Urgorri V., León R., Medialdea T., Paredes M., González F.J. \& Nombela M.A. 2014. Detection and mapping of cold-water coral mounds and living Lophelia reefs in the Galicia Bank, Atlantic NW Iberia margin. Marine Geology 349: 73-90. https://doi.org/10.1016/j.margeo.2013.12.017

Souto J., Berning B. \& Ostrovsky A.N. 2016. Systematics and diversity of deep-water Cheilostomata (Bryozoa) from Galicia Bank (NE Atlantic). Zootaxa 4067 (4): 401-459.

https://doi.org/10.11646/zootaxa.4067.4.1

Souza L.S. de \& Pimenta A.D. 2014. Fusceulima and Halielloides (Gastropoda: Eulimidae) in the southwestern Atlantic, with descriptions of two new species of Fusceulima. Zoologia 31 (6): 621-633. https://doi.org/10.1590/S1984-46702014000600008

Staudigel H., Koppersa A.P., Lavelle J.W., Pitcher T.J.P. \& Shank T.M. 2010. Defining the word "seamount". Oceanography 23 (1): 20-21. https://doi.org/10.5670/oceanog.2010.85 
Steiner G. 1994. Variations in the number of intestinal loops in Scaphopoda. Marine Ecology 15 (2): 165-174. https://doi.org/10.1111/j.1439-0485.1994.tb00051.x

Steiner G. \& Kabat A.R. 2004. Catalog of species-group names of Recent and fossil Scaphopoda (Mollusca). Zoosystema 26 (4): 549-726.

Surugiu V., Dauvin J.-C., Gillet P. \& Ruellet T. 2008. Can seamounts provide a good habitat for polychaete annelids? Example of the northeastern Atlantic seamounts. Deep Sea Research I 55 (11): 1515-1531. https://doi.org/10.1016/j.dsr.2008.06.012

Templado J., Ballesteros E., Galparsoro I., Borja A., Serrano A., Martín L. \& Brito A. 2012. Guía Interpretativa. Inventario Español de Hábitats Marinos. Ministerio de Agricultura, Alimentación y Medio Ambiente, Madrid.

Tiberi N. 1855. Descrizione di alcuni testacei viventi viventi nel Mediterraneo. Lettere di Nicola Tiberi. Privately printed, Napoli. https://doi.org/10.5962/bhl.title.50981

Valeiras J., Abad E., Serrano A., Punzón A. \& Guerra Á. 2012. Records of cephalopod species collected during deepwater surveys at Galicia Bank. In: XIII International Symposium on Oceanography of the Bay of Biscay. ISOBAY 13. Santander, Spain. 11-13 April 2012. Book of Abstracts: 129. Available from http://www.ieo-santander.net/isobay13/abstract_booklet.pdf [accessed 7 Mar. 2021].

van Aartsen J.J. 1987. European Pyramidellidae: III. Odostomia and Ondina. Bollettino Malacologico $23(1-4): 1-34$.

Vázquez J.T., Medialdea T., Ercilla G., Somoza L., Estrada F., Fernández Puga M.C., Gallart J., Gràcia E., Maestro A. \& Sayago M. 2008. Cenozoic deformational structures on the Galicia Bank Region (NW Iberian continental margin). Marine Geology 249 (1): 128-149.

https://doi.org/10.1016/j.margeo.2007.09.014

Vázquez J.T., Alonso B., Fernández-Puga M.C., Gómez-Ballesteros M., Iglesias J., Palomino D., Roque C., Ercilla G. \& Díaz-del-Río V. 2015. Seamounts along the Iberian Continental Margins. Boletín Geológico y Minero 126 (2-3): 483-514.

Verhecken A. 2002. Atlantic bathyal Cancellariidae (Neogastropoda: Cancellarioidea): Additional data and description of a new species. Journal of Conchology 37: 505-514.

Verhecken A. 2007. Revision of the Cancellariidae (Mollusca, Neogastropoda, Cancellarioidea) of the eastern Atlantic $\left(40^{\circ} \mathrm{N}-40^{\circ} \mathrm{S}\right)$ and the Mediterranean. Zoosystema 29 (2): 281-364.

Verrill A.E. 1872. Results of recent dredging expeditions on the coast of New England. American Journal of Science and Arts (3) 5: 1-16.

Vicente C.S., Frutos I. \& Cartes J.E. 2014. Petalophthalmus papilloculatus sp. nov. (Crustacea: Mysida: Petalophthalmidae), a new bathyal suprabenthic mysid from the Galicia Bank (NE Atlantic Ocean). Zootaxa 3765 (1): 77-91. https://doi.org/10.11646/zootaxa.3765.1.5

Warén A. 1989a. New and little known Mollusca from Iceland. Sarsia 74 (1): 1-28. https://doi.org/10.1080/00364827.1989.10413419

Warén A. 1989b. Taxonomic comments on some protobranch bivalves from the Northeastern Atlantic. Sarsia 74 (4): 223-259. https://doi.org/10.1080/00364827.1989.10413432

Warén A. 1991. New and little known Mollusca from Iceland and Scandinavia. Sarsia 76 (1-2): 53-124. https://doi.org/10.1080/00364827.1991.10413466

Warén A. 1992. New and little known "Skeneimorph" gastropods from the Mediterranean Sea and the adjacent Atlantic Ocean. Bollettino Malacologico 27 (10-12): 149-248. 
Warén A. 1993. New and little known Mollusca from Iceland and Scandinavia. Part 2. Sarsia 78 (3-4): 159-201. https://doi.org/10.1080/00364827.1993.10413534

Warén A. 1996. New and little known Mollusca from Iceland and Scandinavia. Part 3. Sarsia 81 (3): 197-245. https://doi.org/10.1080/00364827.1996.10413622

Warén A. \& Bouchet P. 1990. Laevipilina rolani, a new Monoplacophoran from off southwestern Europe. Journal of Molluscan Studies 56 (3): 449-453. https://doi.org/10.1093/mollus/56.3.449

Warén A. \& Bouchet P. 1991. Mollusca Gastropoda: Systematic position and revision of Haloceras Dall, 1889 (Caenogastropoda, Haloceratidae fam. nov.). In: Crosnier A. et al. (eds) Résultats des Campagnes MUSORSTOM 7. Mémoires du Muséum national d'Histoire naturelle. Série A, Zoologie 150: 111-161.

Watson R.B. 1883. Mollusca of H.M.S. 'Challenger' Expedition.- Part XX. Journal of the Linnean Society (London) 17: 26-40, 112-130, 284-293, 319-340, 341-346.

https://doi.org/10.1111/j.1096-3642.1884.tb02029.x

Watson R.B. 1886. Scaphopoda and Gastropoda. Report on the Scientific Results of the Voyage of H.M.S. Challenger during 1873-76. Zoology 15 (42): 1-756, pls. 1-53. https://doi.org/10.5962/bhl.title.6513

Wessel P. 2007. Seamount characteristics. In: Pitcher T.J., Morato T., Hart P.J.B., Clark M.R., Haggan N. \& Santos R.S. (eds) Seamounts: Ecology, Fisheries and Conservation: 3-25. Blackwell Publishing, Oxford. https://doi.org/10.1002/9780470691953.ch1

White M. \& Mohn C. 2004. Seamounts: a review of physical processes and their influence on seamount ecosystems. OASIS (Oceanic Seamounts: An Integrated Study), Hamburg. Available from https://epic.awi.de/id/eprint/37314/17/OASIS_Oceanography.pdf [accessed 7 Mar. 2021].

Wilson R.R. \& Kaufmann R.S. 1987. Seamount biota and biogeography. In: Keating B.H., Fryer P., Batiza R. \& Boehlert G.W. (eds) Seamounts, Islands and Atolls: 319-334. Geophysical Monograph 43, American Geophysical Union, Washington. https://doi.org/10.1029/GM043p0355

WoRMS Editorial Board. 2021. World Register of Marine Species. Available from http://www.marinespecies.org/index.php [accessed 7 Mar. 2021].

Manuscript received: 16 June 2021

Manuscript accepted: 7 October 2021

Published on: 22 December 2021

Section editor: Rudy Jocqué

Section editor: Thierry Backeljau

Desk editor: Pepe Fernández

Printed versions of all papers are also deposited in the libraries of the institutes that are members of the EJT consortium: Muséum national d'histoire naturelle, Paris, France; Meise Botanic Garden, Belgium; Royal Museum for Central Africa, Tervuren, Belgium; Royal Belgian Institute of Natural Sciences, Brussels, Belgium; Natural History Museum of Denmark, Copenhagen, Denmark; Naturalis Biodiversity Center, Leiden, the Netherlands; Museo Nacional de Ciencias Naturales-CSIC, Madrid, Spain; Real Jardín Botánico de Madrid CSIC, Spain; Zoological Research Museum Alexander Koenig, Bonn, Germany; National Museum, Prague, Czech Republic. 


\section{Supplementary material}

Supp. file 1. Fig. S1. Shipboard drawings made during the SEAMOUNT 1 cruise, in the order of their reference number in Tables 2 and S1. https://doi.org/10.5852/ejt.2021.785.1605.5663

Supp. file 2. Table S1. Detail of Material examined. https://doi.org/10.5852/ejt.2021.785.1605.5665 